МИНИСТЕРСТВО НАУКИ И ВЫСШЕГО ОБРАЗОВАНИЯ РОССИЙСКОЙ ФЕДЕРАЦИИ

ФЕДЕРАЛЬНОЕ ГОСУДАРСТВЕННОЕ АВТОНОМНОЕ ОБРАЗОВАТЕЛЬНОЕ УЧРЕЖДЕНИЕ

ВЫСШЕГО ОБРАЗОВАНИЯ

«ВОЛГОГРАДСКИЙ ГОСУДАРСТВЕННЫЙ УНИВЕРСИТЕТ»

\author{
И.Д. Аникина, А.А. Аникин
}

\title{
ЭКОЛОГО-ЭКОНОМИЧЕСКОЕ РАЗВИТИЕ РЕГИОНОВ: \\ СОВЕРШЕНСТВОВАНИЕ МЕТОДОЛОГИИ И МЕТОДИКИ ОЦЕНКИ
}

\author{
МОНОГРАФИЯ \\ Под редакцией доктора экономических наук, \\ профессора И.Д. Аникиной
}

Волгоград 2019 
УДК 332.1:502.3(470.45)

ББК $65.049(2 \mathrm{P}-4$ Вог $) 28$

A67

Рецензенты:

д-р экон. наук, проф. Е. А. Петрова;

д-р экон. наук, доц. Н. Е. Булетова

Исследование выполнено при финансовой поддержке РФФИ

в рамках научного проекта № 19-010-00356

«Совершенствование методологии оценки эколого-экономического

развития регионов на основе концепции устойчивого развития»

\section{Аникина, И. Д.}

A67 Эколого-экономическое развитие регионов: совершенствование методологии и методики оценки [Текст] : монография / И. Д. Аникина, А. А. Аникин / под ред. д-ра экон. наук, проф. И. Д. Аникиной ; Федер. гос. авт. образоват. учреждение высш. образования «Волгогр. гос. ун-т». - Волгоград : Изд-во ВолГУ, 2019. - 196 с.

\section{ISBN 978-5-9669-1937-5}

В монографии предложены направления совершенствования методологии оценки эколого-экономического состояния и развития регионов на основе концепции устойчивого развития, что позволило определить и научно обосновать методику эколого-экономического развития регионов на основе скорректированного индекса декаплинга (методика углубленного декаплинг-анализа). Предложены рекомендации по разработке системы мониторинга эколого-экономического состояния регионов. Проведена оценка состояния эколого-экономического состояния российских регионов на основе расчета эффекта декаплинга по модели углубленного декаплинг-анализа. Проведен анализ полученных результатов и сгруппированы регионы по наличию эффекта декаплинга, классифицированы секторы, характеризующие качественно различную степень эффективности реализации эколого-экономической политики региона.

Рекомендовано для аспирантов, обучающихся по направлению 38.06 .01 Экономика, магистрантов, обучающихся по направлению 38.04.01 Экономика, 38.04.08 Финансы и кредит, менеджеров, предпринимателей, финансистов, а также для всех, интересующихся проблемами экологического менеджмента.

УДК 332.1:502.3(470.45)

ББК 65.049(2Р-4Вог $) 28$

ISBN 978-5-9669-1937-5

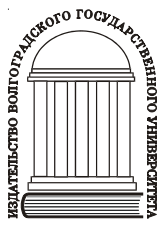

(C) Аникина И.Д., Аникин А.А., 2019

(C) ФГАОУ ВО «Волгоградский государственный университет», 2019

(c) Оформление. Издательство Волгоградского государственного университета, 2019 


\section{ОГЛАВЛЕНИЕ}

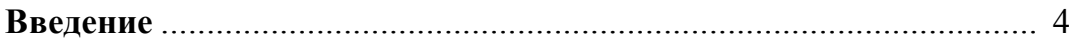

Глава 1. Развитие «зеленой» экономики

как условие устойчивого развития регионов ...................... 10

1.1. Концепция устойчивого экономического роста и теория «зеленого роста» как базис для принятия управленческих решений в современной экономике ....... 10

1.2. Анализ российского законодательства в сфере регулирования климатической политики и практики реализации Парижских соглашений

Глава 2. Совершенствование методологии и методики оценки эколого-экономического развития регионов

2.1. Анализ существующих подходов к оценке эколого-экономической деятельности регионов

2.2. Аналитический инструментарий информационного обеспечения устойчивого развития территорий: методика углубленного декаплинг-анализа ..... 75

2.3. Оценка эффекта декаплинга на примере российских регионов 85

2.4. Эффект декаплинга: особенности регионов ЮФО ........... 96

2.5. Оценка эколого-экономического состояния Волгоградской области

Глава 3. Направления совершенствования инструментария финансирования проектов «зеленой» экономики в Российской Федерации

3.1. Анализ долгосрочных инструментов финансирования проектов «зеленой» экономики (зарубежный опыт) ..... 109

3.2. Совершенствование механизмов и инструментов финансовой поддержки развития «зеленой» экономики в российской экономике

3.3. Оценка рисков эколого-экономического состояния региона: анализ российских регионов

Заключение 143

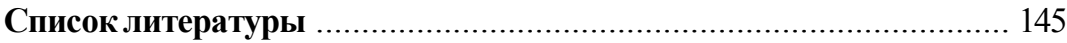

Приложения 156 


\section{ВВЕДЕНИЕ}

Повышение благосостояния общества при снижении экологических проблем и рисков является ключевым аспектом концепции устойчивого развития. Для характеристики устойчивого развития разрабатываются системы индикаторов, которые оценивают используемые средства и уровни достижения целей, но не позволяют сделать однозначные выводы о взаимозависимости экономического развития регионов и территорий и росте/уменьшении экологических угроз и дать оценку эколого-экономических рисков регионов. С целью оценки влияния экономических процессов на окружающую среду в мировой практике применяют декаплинг-анализ, основанный на расчете индекса декаплинга, но без глубокого анализа существующих экологических и экономических проблем территорий.

Степень разработанности проблемы. Значительный вклад в изучение проблемных аспектов мониторинговой оценки эффективности устойчивого развития в российской экономике внесли отечественные ученые: А.О. Акулов, С.Н. Бобылев, Д.А. Борискин, Е.В. Варавин, А.Д. Думнов, С.Н. Кириллов, М.В. Козлова, В.С. Минаков, А.А. Пакина, Н.Г. Рыбальский, В.П. Самарина, Н.И. Тульская, Г.И. Шкиперова, Е.Ю. Яковлева, Н.Н. Яшалова и др. Системы и индикаторы устойчивого развития рассчитывают такие организации как: Всемирный фонд дикой природы (WWF), Bceмирный банк (The World Bank), Организация Объединенных Наций $(\mathrm{OOH})$ и др.

Целью исследования явилось развитие методологии и методов оценки эколого-экономического состояния регионов, а также инструментария процесса мониторинга регионов.

Реализация поставленной цели потребовала решение следующих задач:

- изучить концепцию устойчивого экономического роста, ее составляющие, глобальные экологические проблемы, проблему 
изменения климата, опыт решения проблем окружающей среды в современном мире;

- провести анализ российского законодательства в сфере регулирования климатической политики и практики реализации Парижских соглашений;

- проанализировать существующие системы индикаторов оценки эколого-экономической деятельности регионов;

- уточнить принципы оценки эколого-экономического состояния регионов;

- предложить аналитический инструментарий информационного обеспечения устойчивого развития территорий на основе методики углубленного декаплинг-анализа;

- провести анализ эффекта декаплинга на примере российских регионов;

- разработать инструментарий оценки рисков эколого-экономического состояния региона и провести его апробацию для российских регионов.

Объект исследования - экономические акторы в процессе оценки и мониторинга эколого-экономического состояния регионов.

Предмет исследования - процесс оценки и мониторинга эколого-экономического состояния регионов.

Теоретико-методологической основой исследования послужили фундаментальные труды отечественных и зарубежных ученых в области экспертного оценивания, оценки систем и индикаторов устойчивого развития.

Информационно-эмпирическую базу исследования составили результаты эмпирических исследований отечественных и зарубежных ученых в предметной области, а также результаты собственных исследований авторов. Для получения и обработки результатов использовалось программно-инструментальное средство Microsoft Excel.

\section{Основные положения исследования:}

- Принципами разработки индикаторов эколого-экономического развития регионов являются: принциип динамики (индикаторы должны обеспечивать возможность анализа динамики изменений, мониторинга эффективности деятельности, оценку направ- 
ленности изменений); принции информированности (полезноcmu) (обеспечение обоснованной информации для принятия управленческих решений и отражение информации о существенных эколого-экономических проблемах); принцип учета интересов стейкхолдеров (понятность для стейкхолдеров и отражение информации, полезной для принятия решений многими экономическими субъектами); принщип достоверности (отражение существенной информации, обоснованность затрат). К критериям, которым должны удовлетворять индикаторы относятся следующие: количественная оценка; использование данных официальной статистики; отсутствие экспертных оценочных суждений; возможность оценки в динамике, по уровням экономической системы (макро-, мезо-, микро- уровни), по секторам экономики; конечное число индикаторов.

- Предложена модель углубленного декаплинг-анализа, позволяющая выделить шесть секторов, характеризующих различную степень эффективности эколого-экономического состояния регионов.

- Мониторинг представляет собой систему наблюдений, анализа, оценки, диагностики и коррекции решений в области экономики и экологии. Мониторинг позволяет учесть влияние, которое оказывает реализация экологической стратегии на изменение эффективности бизнеса и региональный экономический рост. Основная роль мониторинга заключается в отслеживании качественных и количественных изменений условий и факторов, существенным образом влияющих на изменение экологической безопасности региона. В качестве объектов мониторинга должны выступать показатели выбросов и загрязнения окружающей среды, а также показатели экономического роста региона. Мониторинг должен обладать свойством упреждаемости, то есть должен позволять решать проблемы до того, как они станут критическими. В этой связи обязательным элементом механизма мониторинга должно стать информационно-аналитическое обеспечение будущих последствий реализации управленческих решений.

- Предложен расчет рейтинга «эколого-экономического риска» региона на основе скорректированного индекса декаплинга. 
Рейтинг целесообразно применять с целью мониторинга эффективности внедрения инновационных эколого-сберегающих технологий и оценки рисков региона. Рейтинг позволит ранжировать регионы по уровню эколого-экономического развития и сделать выводы об эффективности проводимой региональной политики. Проведено исследование 80 российских регионов и определен рейтинг «эколого-экономического риска» регионов.

- Проведена апробация модели углубленного декаплинг-анализа на примере 80 российских регионов, полученные результаты позволяют сделать вывод о наличии эффекта декаплинга в сравнении с 2010 г., но экономические кризисы оказали существенное негативное влияние как на экономическую, так и на экологическую динамику многих российских регионов.

Научная новизна результатов исследования заключается в следующем:

- Уточнены цели, принципы (динамики, информированности, полезности, достоверности), критерии (количественная оценка, возможность оценки в динамики и по уровням экономической системы, по секторам экономики, конечное число индикаторов) разработки индикаторов социально-экономического развития регионов.

- Предложена усовершенствованная модель анализа эффекта «декаплинга», основанная на сопоставлении коэффициентов прироста потребляемых ресурсов и/или загрязнений и показателями экономического роста. Модель позволяет выделить шесть секторов, характеризующих различную степень эффективности эколого-экономического состояния региона. Считаем, что разработанная модель поможет своевременно диагностировать экологические и экономические проблемы и риски региона.

- Предложено проводить мониторинг эколого-экономического состояния региона на основе анализа взаимной динамики показателей выбросов загрязняющих веществ и динамики валового регионального продукта, что соответствует принципам концепции устойчивого развития.

- Проведена апробация предложенных моделей и методик (декаплинг-анализа и эколого-экономического риска регионов) на примере 80 российских регионов. 
Теоретическая значимость исследования заключается в развитии методологии и теоретической базы решения актуальной задачи мониторинга и оценки эколого-экономического состояния регионов, позволяющая позволяющей более полно учитывать взаимосвязь экологического и экономического развития регионов. Полученные теоретические положения могут быть использованы при проведении дальнейших исследований в области мониторинга устойчивого развития регионов.

Практическая значимость исследования заключается в возможности использования предложенных моделей и инструментальных средств при оценке эколого-экономического состояния регионов. Практическая значимость исследования подтверждается апробацией предложенных моделей на примере российских регионов.

Методология и методы исследования. Теоретическая часть исследования выполнена на основе анализа трудов отечественных и зарубежных специалистов по проблемам экономикоматематического моделирования. Разработка моделей и инструментальных средств проводилась с применением положений и принципов экономической теории, системного анализа, теории принятия решений, математической статистики. Численные эксперименты проведены с применением современных средств вычислительной техники.

Апробация результатов исследования. Теоретические положения и практические результаты исследования представлялись автором на научно-практических конференциях: Альтернативы регионального развития: материалы VIII ежегод. Междунар. конф., посвящ. памяти ученого и гос. деят. И.П. Шабунина, г. Волгоград, 25-27 окт. 2017 г.; Международная конференция «Competitive, Sustainable and Secure Development of the Regional Economy: Response to Global Challenges» (CSSDRE 2018); III Международная научная конференция студентов специалитета, бакалавриата и магистратуры «Современное состояние и перспективы развития национальной финансово-кредитной системы» (Российский экономический университет им. Г.В. Плеханова Воронежский филиал) ноябрь, 2018; V Bce- 
российская (национальная) научно-практическая конференция «Разработка стратегии социальной и экономической безопасности государства» (Курганская государственная сельскохозяйственная академия им. Т.С. Мальцева), февраль 2019; Международная конференция «Competitive, Sustainable and Secure Development of the Regional Economy: Response to Global Challenges» (CSSDRE 2019), Международная научная конференция памяти олега Васильевича Иншакова «Конкурентоспособная Россия: форсайт-модель экономического и правового развития в цифровую эпоху (Волгоградский государственный университет), сентябрь 2019.

В первой главе рассмотрены теория и концепция устойчивого экономического роста, проведен анализ институциональных аспектов решения глобальных экологических проблем, выделены проблемы реализации международных соглашений в сфере климатических соглашений, рассмотрено нормативно-информационное обеспечение устойчивого развития российских территорий в области регулирования климатической политики.

Во второй главе проведен анализ существующих подходов систем индикаторов оценки эколого-экономической деятельности регионов, выявлены их преимущества и недостатки, предложен аналитический инструментарий информационного обеспечения устойчивого развития территорий на основе методики углубленного декаплинг-анализа, представлен программный комплекс визуализации декаплинг-анализа, проведена адаптация метода на примере российских регионов.

В третьей главе представлены направления совершенствования инструментария финансирования проектов зеленой экономики в Российской Федерации: проанализирован зарубежный опыт финансирования экологических проектов посредством выпуска «зеленых» облигаций, рассмотрены возможности его применения в российской экономике, предложено включать в рейтинговые оценки облигаций оценку рисков эколого-экономического состояния регионов. Проведена оценка эколого-экономического риска на примере российских регионов. В заключении сформулированы основные выводы проведенного исследования. 


\section{Глава 1. РАЗВИТИЕ “ЗЕЛЕНОЙ" ЭКОНОМИКИ КАК УСЛОВИЕ УСТОЙЧИВОГО РАЗВИТИЯ РЕГИОНОВ}

\section{1. Концепция устойчивого экономического роста и теория «зеленого роста» как базис для принятия управленческих решений в современной экономике}

Важность рассмотрения экологических проблем как отдельных регионов, так и мира в целом, не вызывает сомнения, поскольку именно качество окружающей среды формирует качество жизни населения. Внимание к проблемам экологии, их взаимосвязь и взаимозависимость с экономическими проблемами привело к формированию концепции устойчивого экономического роста и разработке теории «зеленого роста». Данные концепции и теория в настоящее время активно обсуждаются и внедряются в практику мировой и региональных экономик. Они являются основой для принятия политических, экономических, финансовых, технических решений как на межгосударственном уровне, на уровне отдельных государств, регионов, компаний, каждого человека в отдельности. Принципы «зеленой» экономики были представлены Программой ООН по окружающей среде (ЮНЕП - United Nations Environment Programme) в докладе «Глобальный зеленый новый курс» в 2009 г. ${ }^{1} 2009$ год был годом мирового финансового кризиса и именно кризис привел к осознанию невозможности дальнейшего развития по модели докризисного экономического роста.

${ }^{1}$ Глобальный зеленый новый курс. Доклад, март 2009 г. Издано Программой ООН по окружающей среде в рамках Инициативы по зеленой экономике. // http:/www.unepcom.ru/images/greeneconomy/greennewdeal.pdf. 
Докризисные годы, говорится в Докладе ${ }^{2}$, характеризовались инвестициями в «собственность, ископаемые виды топлива и структурированные финансовые продукты со встроенными производными инструментами, но сравнительно мало средств было вложено в возобновляемые источники энергии, энергосбережение, общественный транспорт, устойчивое сельское хозяйство, а также в охрану и рациональное использование земельных и водных ресурсов», что привело к возникновению «множественных»³ кризисов: финансовому, негативному изменению климата, продовольственному и топливному кризисам. Это привело к пониманию и разработке новых целей мировой экономики, таких как:

1) сохранение и создание новых рабочих мест, защита беднейших слоев населения (краткосрочная перспектива),

2) достижение «Целей развития тысячелетия»», к которым относятся ликвидация бедности, уменьшение выбросов углерода, восстановление экосистем, обеспечение стабильного экономического развития.

В программе были определены ключевые направления и принципы инвестирования и посткризисной экономике, такие как: стимулирование инвестиций в безотходные технологии, регенерация инфраструктуры окружающей среды (леса, водные ресурсы, воздух, почвы). Устойчивый экономический рост должен обеспечиваться за счет воссоздания и развития «зеленой» инфраструктуры и повышения качества жизни населения.

Таким образом концепция устойчивого экономического развития связывает повышение благосостояния людей со снижением экологических рисков, декларирует экономический рост при одновременном улучшении /неухудшении окружающей среды (см. рис. 1).

${ }^{2}$ Глобальный зеленый новый курс. Доклад, март 2009 г. Издано Программой ООН по окружающей среде в рамках Инициативы по зеленой экономике // http://www.unepcom.ru/images/greeneconomy/greennewdeal.pdf, c. 4.

${ }^{3}$ Глобальный зеленый новый курс. Доклад, март 2009 г. Издано Программой ООН по окружающей среде в рамках Инициативы по зеленой экономике // http://www.unepcom.ru/images/greeneconomy/greennewdeal.pdf, c. 5. 
Концепция устойчивого экономического развития явилась ответом на современные глобальные проблемы и вызовы, стоящие перед человечеством. Глобальные проблемы - это проблемы, от которых зависит развитие / выживание человечества в целом. Глобальные проблемы имеют следующие особенности:

- в значительной степени вызваны ценностными установками, стереотипами, культурными паттернами западноевропейского общества, но в настоящее время эти ценности и установки опосредуют развитие всего человечества;

- затрагивают каждого человека на планете;

- требуют согласованных решений на межгосударственном уровне.

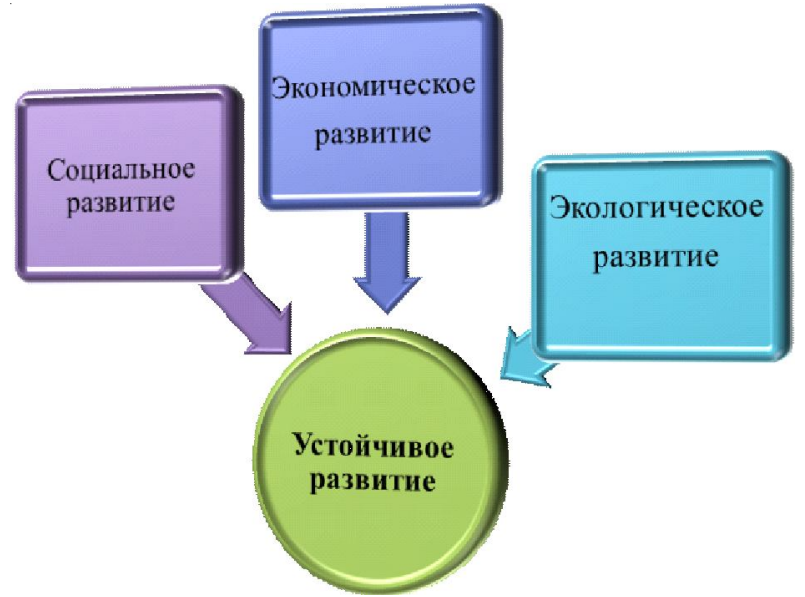

Рис. 1. Составляющие концепции устойчивого развития

Примечание. Источник: составлено автором на основе: Устойчивое развитие: концепция, принципы, цели // csrjournal.com/ustojchivoe-razvitie-koncepciyaprincipy-celi.

В.И. Данилов-Данильян (академик РАН, проф., д-р экон наук, научный руководитель Института водных проблем РАН) отмечает, что «существование глобальных проблем было осознано в середине 1960-х годов, тогда же они стали предметом научных исследований и научных дискуссий в развитых странах и СССР, а в 
следующем десятилетии - в и третьем мире» ${ }^{4}$. Как отмечает ученый, «исторически первой глобальной проблемой, ... была угроза ядерной войны». Карибский кризис 1962 г. и последовавшие за ним различные международные соглашения показали возможность решений и компромиссов таких сложных вопросов. В тоже время распространение ядерного оружия среди стран-не членов ядерного клуба, появление новых видов вооружения, непрекращающиеся региональные и локальные войны говорят, к сожалению, об ограниченных успехах решений данной глобальной проблемы. После 11 сентября 2001 года серьезной глобальной проблемой стал терроризм, рецепт решения которой пока еще не найден. Изучение военных глобальных проблем привело к необходимости изучения социально-экономических причин их появления и выявления факторов влияния. Одним из таких факторов (и в тоже время одной из глобальных проблем) является демографический фактор. Средства сдерживания демографического роста будут являться решением и других связанных проблем, в частности, экологической проблемы.

Экологическая проблема - одна из наиболее значимых глобальных проблем, в решении которой может принять участие каждый человек. Впервые глобальная экологическая проблема была сформулирована в 1972 г. в докладе Римскому клубу «Пределы роста ${ }^{5}$. В докладе авторы представили 12 сценариев развития человечества в зависимости от различных условий. Таких как: невозобновляемые ресурсы; промышленный капитал; сельскохозяйственный капитал; капитал сферы услуг; свободная земля; сельхозугодья; городская и промышленная земля; неудаляемые загрязнители; народонаселение. Авторы доклада показали, что при неизменных условиях - базовый сценарий «ничего не делать» человечеству к 2100 г. грозит пик развития с последующим бес-

${ }^{4}$ Устойчивое развитие: Новые вызовы : Учебник для вузов / Под. общ. ред. В.И. Данилова-Данильяна, Н.А. Пискуловой. - М.: Издательство «Аспект Пресс», 2015. - 336 с., с.11.

${ }^{5}$ Медоуз Д. Х., Медоуз Д.Л., Рэндерс Й., Беренс III В. Пределы роста / пер. с англ. - М.: Изд-во МГУ. - 1991. - 207 с. 
контрольным сокращением населения и резким спадом уровня жизни, в дальнейшем ожидается ограничение по продовольствию и голод. Доклад привел к осознанию проблемы, которая заключается в том, что увеличивающаяся антропогенная нагрузка на окружающую среду превысила в настоящее время допустимый предел и угрожает выживанию человечества.

К глобальным экологическим проблемам (угрозам) можно отнести следующие:

1) истощение озонового слоя;

2) резкие и быстрые климатические изменения;

3) сокращение биологического разнообразия;

4) дефицит (shortage) пресной воды и истощение природных ресурсов (биологических, ископаемых).

Все глобальные проблемы взаимосвязаны и, по нашему мнению, имеют единую природу, а именно - быстрое изменение климата, которое в немалой степени вызвано истощением озонового слоя. В свою очередь опасность быстрых климатических изменений состоит в том, что биота с высокой степенью вероятности не может адаптироваться к быстрым изменениям климата. А истощение природных ресурсов опосредовано применяемыми технологиями.

Решение глобальных экологических проблем на данном этапе зависит от разработки соглашений и принятии мер на межгосударственном уровне. К базовому соглашению, которое определяет принципы международного консенсуса в сфере контроля за изменениями климата, относится Рамочная конвенция ООН по изменению климата ${ }^{6}$, в которой сформулированы направления, принципы и меры по смягчению климатических изменений и их последствий.

Конвенция признает, что «изменение климата Земли и его неблагоприятные последствия являются предметом общей озабоченности человечества», цель конвенции «заключается в том,

${ }^{6}$ Рамочная конвенция Организации Объединенных Наций об изменении климата. Принята 9 мая 1992 года //https://www.un.org/ru/documents/decl_conv/ conventions/climate_framework_conv.shtml. 
чтобы добиться во исполнение соответствующих положений Конвенции стабилизации концентраций парниковых газов в атмосфере на таком уровне, который не допускал бы опасного антропогенного воздействия на климатическую систему. Такой уровень должен быть достигнут в сроки, достаточные для естественной адаптации экосистем к изменению климата, позволяющие не ставить под угрозу производство продовольствия и обеспечивающие дальнейшее экономическое развитие на устойчивой основе» ${ }^{7}$.

Но существуют и отрицательные аргументы исследователей относительно возможностей антропогенного влияния на изменения климата. Резкие изменения климата по мнению различных национальных и международных организаций вызваны воздействием деятельности человека на окружающую среду, а именно - увеличение выбросов парниковых газов приводит к увеличению парникового эффекта (повышению температуры нижних слоев атмосферы), что приводит к дополнительному нагреву атмосферы. Но, по одной из альтернативных точек зрения, изменения температуры атмосферы Земли могут быть вызваны циклами Миланковича ${ }^{8}$.

Парниковый эффект, доказывают ученые, только в небольшой степени обусловлен теми газами, на количество которых деятельность человека может оказывать влияние (вклад париковых газов - $26 \%$ (из них доля $\mathrm{CO}_{2}-19 \%$ ) от атмосферных факторов в парниковый эффект, облака - $25 \%$, водяной пар $-49 \%{ }^{9}$ ). Водяной пар обеспечивает около 50 \% парникового эффекта, но его

7 Рамочная конвенция Организации Объединенных Наций об изменении климата. Принята 9 мая 1992 года // https://www.un.org/ru/documents/decl_conv/ conventions/climate_framework_conv.shtml.

${ }^{8}$ Циклы Миланковича - колебания достигающего Земли количества света и солнечной радиации на протяжении больших промежутков времени. Источник: Аналитический доклад «Риски реализации Парижского климатического соглашения для экономики и национальной безопасности» / Институт проблем естественных монополий. - Москва, 2016, 114 с., с. 8.

${ }^{9}$ Аналитический доклад «Риски реализации Парижского климатического соглашения для экономики и национальной безопасности» / Институт проблем естественных монополий. - Москва, 2016, 114 с., с. 11. 
исключают из рассмотрения при дискуссиях о росте парникового эффекта, поскольку нет данных о его изменении в атмосфере. Среди исследователей-экологов нет однозначного мнения о причинах роста средней температуры Земли. Так позиция ученых Межправительственной группы экспертов по изменению климата (МГЭИК): «весьма вероятно, что основной наблюдаемый прирост глобальной средней температуры с середины 20-го века обеспечен наблюдаемым ростом концентраций в атмосфере антропогенных парниковых газов» ${ }^{10}$. Позиция экспертов Неправительственной ГЭИК: «неочевидно, что именно антропогенный фактор является причиной потепления» и «корреляция между температурой и концентрацией $\mathrm{CO}_{2}$ слабая и неубедительная» ${ }^{11}$.

Отсутствие жесткой факторной зависимости между ростом антропогенного воздействия на окружающую среду и изменением климата признается и в докладах МГЭИК, а повышение концентрации парниковых газов имеет не только негативных последствия, но и положительные. Например, исследования свидетельствую о росте суммарной площади растительной листвы, что вызвано, в первую очередь ростом концентрации $\mathrm{CO}_{2}$ в атмосфере ${ }^{12}$.

Несмотря на имеющиеся неоднозначные мнения ученых относительно возможности и оценки последствий антропогенного воздействия на озоновый слой Земли и изменения климата, Римская конвенция и последующие за ней соглашения определили повестку дня многих, если не большинства стран мира в сфере экологии и на настоящий момент национальные стратегии развития стран разрабатываются с учетом Климатических соглашений, последствия которых оказывают влияния на развитие техно-

${ }^{10}$ Цитировано по: Аналитический доклад «Риски реализации Парижского климатического соглашения для экономики и национальной безопасности» / Институт проблем естественных монополий. - Москва, 2016, 114 с., с. 9.

${ }^{11}$ Цитировано по: Аналитический доклад «Риски реализации Парижского климатического соглашения для экономики и национальной безопасности» / Институт проблем естественных монополий. - Москва, 2016, 114 с., с. 9.

12 Аналитический доклад «Риски реализации Парижского климатического соглашения для экономики и национальной безопасности» / Институт проблем естественных монополий. - Москва, 2016, 114 с., с. 9. 
логий, на принятие управленческих решений, на образовательные программы, на финансовые инструменты, на поведение многих и многих государств, компаний, индивидов.

Римская конвенция определяет следующие принципы, на которых она основывается ${ }^{13}$ :

1. Защита климатической системы на благо всего человечества на основе справедливости и общей, но дифференцированной ответственностью, согласно которой развитые страны должны играть ведущую роль в борьбе с изменениями климата и его последствиями.

2. Учет потребностей развивающихся стран, особенно тех, которым особенно угрожают отрицательные последствия изменения климата.

3. Необходимость принимать превентивные меры в целях смягчения отрицательных последствий изменения климата. Недостаточная научная определенность не должна служить причиной для отсрочки принятия таких мер. Меры должны быть экономически эффективными, а проводимая политика учитывать различные социально-экономические условия.

4. Стороны имеют право на устойчивое развитие, поэтому политика и меры защиты климатической системы должны быть интегрированы с национальными программами развития, не противоречить экономическому развитию стран.

5. Стороны должны сотрудничать в целях устойчивого развития всех сторон. Меры по защите климатической системы не должны носить дискриминационный характер или скрытого ограничения международной торговли.

Продолжением и развитием Рамочного соглашения явился Киотский протокол (Киотский протокол к Рамочной конвенции Организации Объединенных Наций об изменении климата $\left.{ }^{14}\right)$, при-

${ }^{13}$ Рамочная конвенция Организации Объединенных Наций об изменении климата. Принята 9 мая 1992 года //https://www.un.org/ru/documents/decl_conv/ conventions/climate_framework_conv.shtml.

${ }^{14}$ Киотский протокол к Рамочной конвенции Организации Объединенных Наций об изменении климата. Официальный сайт ООН // https://www.un.org/ru/ documents/decl_conv/conventions/kyoto.shtml. 
нятый 159 государствами 11 декабря 1997 г. и вступивший в силу 16 февраля 2005 г. Завершение первого этапа (базового обязательства) протокола завершилось 31 декабря 2012 г. В протоколе зафиксировано намерение снизить выбросы парниковых газов в атмосферу на 5,2 \% ${ }^{15}$ в период 2008-2012 гг. по сравнению с уровнем 1990 г. Достичь такого результата (и вступить в силу Киотский договор) должны были выполнение следующих условий: подписание договора не менее 55 государствами и к «протоколу должны были присоединиться государства, на долю которых в совокупности в 1990 г. приходилось не менее 55 \% общих выбросов парниковых газов. К сентябрю 2004 г. документ ратифицировали 124 государства, однако их суммарный объем эмиссий $\mathrm{CO}_{2}$ не превышал 44 \%. Судьба документа зависела от России, которая на тот момент занимала третье место в мире после США и Китая по объему выбросов парниковых газов. Документ вступил в силу в феврале 2005 г. лишь после присоединения к нему РФ ${ }^{16}$.

В Киотском протоколе содержится перечень парниковых газов, подлежащих контролю, к которым отнесены следующие : диоксид углерода $\left(\mathrm{CO}_{2}\right)$, метан $\left(\mathrm{CH}_{4}\right)$; закись азота $\left(\mathrm{N}_{2} \mathrm{O}\right)$; гидрофторуглероды (ГФУ); перфторуглероды (ПФУ); гексафторид серы $\left(\mathrm{SF}_{6}\right)$. Также определены количественные обязательства сторон (стран) по ограничению или сокращению выбросов (в процентах от базового года или периода). Для Российской Федерации доля осталась на уровне $100 \%$ от 1990 г.

Киотский протокол стал институциональной основой для создания мирового углеводородного рынка, на котором страны, превышающие определенные протоколом лимиты могли их приобрести в размере превышения лимитов. Страны получили возможность продавать и покупать квоты на выбросы парниковых газов. По мнению экспертов ООН, это позволило развивающимся странам получать средства для природоохранной деятельности.

${ }^{15}$ TACC // https://tass.ru/info/2297422.

${ }^{16}$ TACC // https://tass.ru/info/2297422. 
Результатом первого этапа явилось создание действующего механизма мирового уровня по охране окружающей среды, основанного на рыночных методах. Вместе с тем реализация Киотского протокола выявила и его сложности: Китай и Индия отказались брать на себя обязательства по его исполнению. США заявили о своем неучастии до 2013 года. Россия подписала договор в 1999 г., но ратифицировала только в ноябpe 2004 г. ${ }^{17}$.

В декабре 2012 года был утвержден второй период Киотского протокола (Киото-2), период действия которого с 01 января 2013 г. до 2020 г. Киото-2 приняли такие страны как Евросоюз, Австралия, Казахстан, Украина, Белоруссия, Норвегия, Швейцария, Исландия, Лихтенштейн, Монако.

Россия, Япония, Новая Зеландия и Канада отказались участвовать во втором этапе ${ }^{18}$. Одной из причин отрицательной позиции России стало изменение механизмов соглашения, в частности, отмена торговли эмиссионными сертификатами с 2013 года, поскольку, как отмечает Frankfurter Allgemeine, «эта продажа лишь увеличила выброс парниковых газов в мировом масштабе» ${ }^{19}$. Также Frankfurter Allgemeine отмечает, что торговля квотами «привлекла в страну (Россию - А.) инвестиции на сумму в почти 600 миллионов долларов» ${ }^{20}$.

Оценивая эффективность Киотского договора, следует отметить, что к договору присоединились страны, которые обеспечивают в совокупности только $15 \%{ }^{21}$ выбрасываемых в атмосферу вредных парниковых газов.

${ }^{17}$ Вестник отделения наук о Земле РАН // https:/onznews.wdcb.ru/images/ news $16 /$.

${ }^{18}$ Вестник отделения наук о Земле РАН // https://onznews.wdcb.ru/images/ news $16 /$.

${ }^{19}$ Frankfurter Allgemeine // https:/www.dw.com/ru/frankfurter-allgemeineмосква-не-хочет-присоединяться-к-договору-киото-2/a-16408103.

${ }^{20}$ Frankfurter Allgemeine // https:/www.dw.com/ru/frankfurter-allgemeineмосква-не-хочет-присоединяться-к-договору-киото-2/a-16408103.

${ }^{21}$ Frankfurter Allgemeine // https:/www.dw.com/ru/frankfurter-allgemeineмосква-не-хочет-присоединяться-к-договору-киото-2/a-16408103. 
12 декабря 2015 г. подписано Парижское соглашение, которые провозглашают своей целью развитие усилий по снижению выбросов парниковых газов и являются развитием Рамочного соглашения и Киотского протокола. Соглашение получило поддержку 196 стран. Соглашение предусматривает, что к 2020 г. стороны соглашения должны представить и опубликовать национальные стратегии долговременного развития, направленные на достижение целевых показателей выбросов парниковых газов, оговоренные в Парижском соглашении, а также разработать механизмы контроля и обмена опытом, методику адаптации, механизмы поддержки и консультирования развивающихся стран ${ }^{22}$.

По данным ООН «по состоянию на апрель 2018 года, Парижское соглашение по климату было ратифицировано 175 сторонами и 168 сторон предоставило свои национальные планы Секретариату РКООНИК» ${ }^{23}$. Участники соглашения берут на себя обязательства принять все возможные меры для недопущения роста средней температуры Земля более, чем на $2{ }^{\circ} \mathrm{C}$, а с учетом важности проблемы - ограничить рост $1,5^{\circ} \mathrm{C}^{24}$. В рамках соглашения развитые страны выделяют на научные исследования в области низкоуглеродных источников энергии 100 млрд долл., после 2015 года эта сумма может увеличиться ${ }^{25}$.

Отметим, что наибольшее количество выбросов $\mathrm{CO}_{2}$ на душу населения в 2016 г. демонстрировал Катар - 38,52 тонны на душу населения, далее следуют Тринидад и Тобаго - 25,72; Кувейт 25,06; ОАЭ - 23, $60^{26}$.

22 Парижское соглашение // https://treaties.un.org/doc/Treaties/2016/02/ 20160215\%2006-03\%20PM/Ch_XXVII-7-d.pdf.

${ }^{23}$ Официальный сайт ОӦН // https:/www.un.org/sustainabledevelopment/ ru/climate-change/.

${ }^{24}$ Официальный сайт ООН // https://www.un.org/sustainabledevelopment/ ru/climate-change/.

${ }^{25}$ Вестник отделения наук о Земле РАН // https://onznews.wdcb.ru/images/ news16/ info_160307.html.

${ }^{26}$ Дубовик О.Л., Аверина К.Н. Значение Парижского соглашения для охраны климата: крупномасштабные планы и проблемы с их реализацией // Международное право и международные организации. - 2018. - № 4 // Система КонсультантПлюс: Юридическая пресса. 
Исследователи отмечают и другие международные проблемы, возникающие при реализации соглашения. Так, в рамках соглашения планируется прекращения вырубки лесов и превращение их в заповедные зоны. Это может привести к переселению коренных жителей Либерии (по оценкам число пострадавших жителей может составить до 300 тыс. человек) и Конго (оценка населения - миллион человек) ${ }^{27}$ и геополитическим конфликтам.

Еще одна проблема - выход в 2017 г. США из Парижского соглашения по борьбе с климатическими изменениями в связи с тем, что по мнению администрации США, соглашение не отвечает интересам американской экономики. На долю США проходится около четверти мировых вредных выбросов, именно поэтому позиция США чрезвычайно важна для успешной реализации деклараций соглашения. Вместе с тем, как отмечает информационное агентство Интерфакс, администрация не исключает возможность возвращения к соглашениям в будущем ${ }^{28}$. Кроме данного факта отметим, что штаты США, предприниматели, общественные организации продолжают реализовывать меры по борьбе с глобальным потеплением. М. Блумберг - предприниматель, бывший мер Нью-Йорка, поддерживает движение «American Cites Initiative», которому он выделил 200 млн долл., и которое борется за остановку электростанций, работающих на угле. Фонд М. Блумберга сотрудничает в сфере экологии с 91 городами США. М. Блумберг считает важным инициативу граждан в области развития экологически ответственного поведения и ссылается на социологические исследования, согласно которым 70 \% американцев верят, что изменения климата возможно ${ }^{29}$.

${ }^{27}$ Вестник отделения наук о Земле РАН // https:/onznews.wdcb.ru/images/ news16/ info_160307.html.

${ }^{28}$ Официальный сайт Интерфакс https://www.interfax.ru/world/573661.

${ }^{29}$ Цитировано по : Дубовик О.Л., Аверина К.Н. Значение Парижского соглашения для охраны климата: крупномасштабные планы и проблемы с их реализацией // Международное право и международные организации. - 2018. № 4 // Система КонсультантПлюс: Юридическая пресса. 
Парижские соглашения в настоящее время влияют на проведение политики в сфере экологии отдельными странами. Дубовик О.Л., Аверина К.Н. в своей работе приводят такие данные об экологической политике Китая и Индии ${ }^{30}$ :

- Китай планирует инвестировать в производство возобновляемой энергии 340 млрд евро до 2020 г. Для Китая данный шаг важен не только в связи с решением экологических проблем (загрязнение атмосферного воздуха приводит в Китае ежегодно к смерти 1 млн человек), но и с экономической точки зрения - как выход на энергетический рынок: в 2016 г. Китай уже инвестировал за рубежом 32 млрд долл. в возобновляемую энергетику, а внутри станы - 103 млрд долл. в 2015 г., планируется в ближайшие четыре года инвестировать 340 млрд евро в решение энергетической проблемы. Китайские предприниматели, не проявляющие солидарности с проводимой правительством политикой, несут убытки - прогнозируемые потери сектора по производству энергии от угля в размере от 400 до 1000 млрд долл., что составляет 4,1-9,5 \% ВВП по состоянию на 2015 г.

- Индия проводит радикальную политику перехода на возобновляемые источники энергии: к 2022 г. планируется увеличить долю этого источника в четыре раза. В Индии ветровая и солнечная энергии дешевле, получаемой от угольных электростанций и, если сначала специалисты оценивали план как нереальный, то в настоящее время оценки изменились на положительные.

На 22 и 23 климатических конференциях продолжилась разработка механизмов и инструментов по реализации Парижских соглашений. Так были приняты следующие шаги:

1) Принята программа «Talanoa-Dialogue» (концепция предложена Фиджи), которая предполагает создание площадки для обмена идеями, опытом, а также организацию действий в целях сохранения природы и защиты окружающей среды: «Talanoa is a

30 Дубовик О.Л., Аверина К.Н. Значение Парижского соглашения для охраны климата: крупномасштабные планы и проблемы с их реализацией // Международное право и международные организации. - 2018. - № 4 // Система КонсультантПлюс: Юридическая пресса. 
traditional word used in Fiji and across the Pacific to reflect a process of inclusive, participatory and transparent dialogue. The purpose of Talanoa is to share stories, build empathy and to make wise decisions for the collective good. The process of Talanoa involves the sharing of ideas, skills and experience through storytelling. During the process, participants build trust and advance knowledge through empathy and understanding. Blaming others and making critical observations are inconsistent with building mutual trust and respect, and therefore inconsistent with the Talanoa concept. Talanoa fosters stability and inclusiveness in dialogue by creating a safe space that embraces mutual respect for a platform for decision making for a greater good $\iota^{31}$.

2) В ноябре 2017 г. был создан альянс государств по отказу от использования угля, который является наиболее грязным источником энергии. Страны договорились отказаться от данного ресурса к 2030 г. В состав альянса вошли Австрия, Ангола, Бельгия, Великобритания, Дания. Италия, Канала, Люксембург, Маршалловы острова, Мексика. Нидерланды, Ниуэ, Новая Зеландия. Португалия, Сальвадор, Фиджи, Финляндия, Франция, Швейцария, Эфиопия. В тоже время от участия отказались такие крупные игроки на этом рынке как Китай, Индия, Германия, Польша. Конкретные планы по отказы от угля разработали только десять стран: Новая Зеландия (отказ к 2022 г.), Франция (к 2023), Австрия и Великобритания (к 2025), Канада, Дания, Нидерланды, Португалия, Финляндия, Швеция (к 2030) ${ }^{32}$.

3) Началась работа по созданию программы взаимовлияния сельского хозяйства и климата.

4) Приняты решения об увеличении субсидий развивающимся странам для финансирования мер по борьбе с глобальным потеплением, но механизмы финансирования еще не определены.

«23 сентября 2019 года Генеральный секретарь ООН проведет Саммит по мерам в области изменения климата, на котором

${ }^{31}$ Официальный сайт программы Talanoa-Dialogue"// https:// talanoadialogue.com/.

32 Дубовик О.Л., Аверина К.Н. Значение Парижского соглашения для охраны климата: крупномасштабные планы и проблемы с их реализацией // Международное право и международные организации. - 2018. - № 4 // Система КонсультантПлюс: Юридическая пресса. 
предполагается принять «климатический вызов» ${ }^{33},-$ отмечается на сайте ООН. Девиз саммита: «А race we can win» - гонка (поборьбе с изменением климата), которую можно выиграть. Генеральный секретарь ООН Антониу Гутерриш отмечает: «Приемлем только значительно более высокий уровень амбициозности обязательств. В связи с этим работа Саммита будет сосредоточена на областях, лежащих в основе проблемы, - секторах, в которых создаются наиболее высокие выбросы, а также областях, в которых обеспечение устойчивости будет иметь наибольшее значение» ${ }^{34}$.

Важность рассматриваемых проблем, их первостепенность для выживания человечества подтверждают исследования Межправительственной группы экспертов по изменению климата, которые делают следующие выводы: «В период с 1880 по 2012 годы средняя мировая температура повысилась на 0,85 градуса Цельсия. При этом каждый прирост температуры на 1 градус приводит к сокращению урожая зерновых примерно на 5 процентов. В период с 1981 по 2002 годы мировой урожай кукурузы, пшеницы и других основных культур значительно снизился - на 40 мегатонн в год.

Рост температуры океанов и уменьшение количества снега и льда привели к повышению уровня моря. В период с 1901 по 2010 годы среднемировой уровень моря поднялся на 19 сантиметров в связи с увеличением количества воды в океанах, что вызвано общим потеплением и таянием ледников. Каждое десятилетие, начиная с 1979 года, площадь арктических морских льдов сокращается на 1,07 миллиона квадратных километров.

Если не обеспечить реализацию единственного возможного сценария, то с учетом нынешнего уровня концентрации парниковых газов в атмосфере и продолжения выбросов к концу этого века прирост мировой температуры, вероятно, превысит отметку в 1,5 градуса Цельсия, установленную в период с 1850 по 1900 годы. Температура Мирового океана будет расти, и ледники

\footnotetext{
${ }^{33}$ Официальный сайт ООН // https://www.un.org/ru/climatechange/.

${ }^{34}$ Официальный сайт ООН // https://www.un.org/ru/climatechange/unclimate-summit-2019.shtml.
} 
продолжат таять. Средний уровень моря, по прогнозам, к 2065 году поднимется на 24-30 сантиметров, а к 2100 году - на 40-63 сантиметра. Большинство последствий изменения климата сохранятся еще на много веков, даже если выбросы прекратятся.

Начиная с 1990 года, мировой объем выбросов углекислого газа $\left(\mathrm{CO}_{2}\right)$ увеличился почти на 50 процентов.

За период с 2000 по 2010 годы объем выбросов рос быстрее, чем в каждое из трех предшествующих десятилетий.

В случае применения широкого спектра технических мер и изменения модели поведения еще есть возможность удержать прирост среднемировой температуры на уровне на 2 градуса Цельсия выше, чем до наступления эпохи индустриализации.

Наиболее реальные перспективы избежать выхода глобального потепления за эти рамки появляются при проведении масштабных институциональных и технологических изменений» ${ }^{35}$.

Важная роль в борьбе с экологическими проблемами принадлежит и общественным организациям, которые оказывают значительное влияние на изменение как сознания (культурные и ментальные установки), так и на поведение и индивидуумов, и государств.

Коммерческие организации все больше осознают свою ответственность в решение проблем окружающей среды и внедряют стандарты ответственного поведения. Организации внедряют новые инновационные технологии в области «зеленой экономики», направленные на «повышения энергоэффективности, окращение углеродного следа продукции, услуг и процессов компании» ${ }^{36}$. Компании применяют в своей деятельности целевые показатели сокращения вредных выбросов в соответствии с научными достижениями, увеличивают финансирование инвестиций в разработку новаторских и общедоступных продуктов и услуг с учетом проблемы изменения климата и необходимости сокращения углерод-

${ }^{35}$ Официальный сайт ООН // https://www.un.org/sustainabledevelopment/ ru/climate-change/.

${ }^{36}$ Брошюра ООН «МЕРЫ ПО БОРЬБЕ С ИЗМЕНЕНИЕМ КЛИМАТА: ЗНАЧЕНИЕ ДЛЯ БИЗНЕСА» // https://www.un.org/sustainabledevelopment/ru/ climate-change/. 
ного следа. «Предприятия решают проблему изменения климата за счет внедрения инноваций и осуществления долгосрочных вложений в обеспечение энергоэффективности и низкоуглеродного развития. Многие из них присоединились к Повестке дня в области изменения климата ${ }^{37}$ - инициативе, выдвинутой на Саммите ООН по климату в 2014 году в Нью-Йорке и предполагающей объединение правительств, деловых кругов и гражданского общества вокруг новых методов поощрения» ${ }^{38}$.

По данным из 13481 компаний, 57 (0,42\%)- российские компании, которые присоединились к инициативе ООН «Забота о климате» ${ }^{39}$. Среди российских компаний, поддерживающих данную инициативу: Лукойл, РЖД, Роснефть, РУСАЛ, Внешэкономбанк, ГУМ «Норильский никель», Межгосударственная корпорация развития, Северсталь, Русгидро, Экологическая палата России, ОАО «Полюс» и др. Компании декларирует декларируют приверженность принципам социальной ответственности бизнеса, в т.ч. в сфере экологии.

Выводы. Согласно современным научным исследованиям и представлениям, антропогенная нагрузка на окружающую среду превысила допустимый предел и угрожает выживанию человечества. Осознание имеющихся глобальных проблем, наличие политической воли, привели международное сообщество не только к разработке механизмов, методов и инструментов их решения, а также к попыткам их реализации в современном мире. Можно выделить следующий положительный опыт решения проблем окружающей среды в современном мире:

А. Человечество смогло выработать общие решения (стратегию) для борьбы с истощением озонового слоя. Международные соглашения по контролю за изменениями климата являются на текущий момент времени самым успешным примером дос-

${ }^{37} \mathrm{http}: / /$ caringforclimate.org/; https://www.unglobalcompact.org/take-action/ action/climate.

${ }^{38}$ Брошюра ООН «МЕРЫ ПО БОРЬБЕ С ИЗМЕНЕНИЕМ КЛИМАТА: ЗНАЧЕНИЕ ДЛЯ БИЗНЕСА» // https://www.un.org/sustainabledevelopment/ru/ climate-change/.

${ }^{39} \mathrm{https}: / /$ www.unglobalcompact.org/what-is-gc/participants. 
тигнутого и реализуемого консенсуса на международном уровне в сфере решения глобальных проблем.

Соглашения включают принципы деятельности в данной сфеpe, a также конкретные механизмы, направленные на снижение выбросов парниковых газов (цель - не допустить среднее повышение температуры на Земле более чем на $2{ }^{\circ} \mathrm{C}$ по сравнению с базовым периодом (1990 г.).

Сформулированы институциональные основы решения глобальных экологических проблем, которыми являются международные соглашения под эгидой ООН. Разработаны методы решения глобальных экологических проблем (экологизация производства, развитие «зеленой экономики», рационализация потребления, изменение культуры, ценностей человека, возрастание ответственного поведения экономических субъектов) и инструменты финансирования экологических проектов в целях решения экологических проблем (к ним относят налоговые платежи, экологические платежи, штрафы, пошлины, гранты, субсидии, дотации, специальные финансовые инструменты (зеленые облигации)).

К соглашениям присоединяется все большее число государств и стран (129 стран ратифицировали соглашения к 2004 г., 175 стран ратифицировали к 2018 г.). Развивающиеся страны, как отмечают эксперты «сделали шаг доброй воли в стороны роста амбиций по снижению выбросов парниковых газов и прозрачности процесса. Эти страны проработали и предоставили обновленные версии национальных планов и заявили открытость для климатического аудита. Кроме того, отдельные государства заявили о пересмотре своих национальных климатических планов. К примеру, Канада, Германия, Мексика и Соединенные Штаты опубликовали стратегии по радикальному сокращению выбросов парниковых газов ${ }^{40}$.

Несмотря на выход США из Парижских соглашений, до 2022 г. принятые ими обязательства должны будут соблюдать-

${ }^{40}$ Подосенова О. Источник: Дубовик О.Л., Аверина К.Н. Значение Парижского соглашения для охраны климата: крупномасштабные планы и проблемы с их реализацией // Международное право и международные организации. 2018. - № 4 // Система КонсультантПлюс: Юридическая пресса. 
ся ${ }^{41}$, кроме того, политика отдельных штатов и компаний, продолжающих поддерживать экологические программы, компенсирует этот отказ.

Б. Развивается деятельность общественных организаций, оказывающих значительное влияние на формы и методы борьбы с экологическими проблемами. Коммерческие организации осознают свою ответственность в создании и решении проблем окружающей среды и включаются в программы развития «зеленой экономики».

Реализация соглашений сталкивается и с трудностями, к числу которых относятся следующие:

А. Существуют противоречия между странами в понимании положений Парижского соглашения касающиеся негативного влияния применения положений соглашения на национальные интересы. Эксперты отмечают ${ }^{42}$, что страны, импортирующие энергоресурсы, заинтересованы в снижении зависимости от импорта ввиду не только экологических проблем, но и высоких цен и политических рисков (в основном эти европейские страны), что стимулирует развитие ВИЭ (возобновляемые источники энергии), в то время как для стран, производящих и добывающих топливо и энергоресурсы политика ограничений выбросов $\mathrm{CO}_{2}$ является высокорискованной с точки зрения достижения экономической эффективности (к таким странам относятся, как пример, США, Россия).

Б. Невыполнение климатических соглашений не несет для стран ни политических, ни экономических последствий. Так, Австралия и Япония не выполнили обязательства Киотского протокола без последующих последствий.

В. Отдельные страны, в рамках выполнения Парижских соглашений разработали национальные стратегии, в которых пре-

${ }^{41}$ Дубовик О.Л., Аверина К.Н. Значение Парижского соглашения для охраны климата: крупномасштабные планы и проблемы с их реализацией // Международное право и международные организации. - 2018. - № 4 // Система КонсультантПлюс: Юридическая пресса

42 Аналитический доклад «Риски реализации Парижского климатического соглашения для экономики и национальной безопасности России»») / Институт естественных монополий. - Москва, 2016, 114 с., с. 109. 
дусматривается не абсолютное снижение выбросов парниковых газов, а сокращение удельных выбросов на единицу ВВП, что позволит в действительности наращивать объем выбросов в абсолютном выражении.

Г. Методы прямого действия, к которым прибегают в ряде случаев общественные организации и отдельные индивидуумы вызывают отрицательную реакцию и оценку со стороны государственных органов и других экономических субъектов.

\section{2. Анализ российского законодательства В сфере регулирования климатической политики и практики реализации Парижских соглашений}

Россия активно участвует в разработке и реализации международных соглашений по снижению антропогенной нагрузке на окружающую среду и противодействию негативному изменению климата. Еще в 1996 г. был принят Указ Президента Российской Федерации № 440 от 01.04.1996 г. «О концепции перехода Российской Федерации к устойчивому развитию» ${ }^{43}$, а в 2002 г. вступил в действие Ф3 «Об охране окружающей среды» ${ }^{44}$, который является базовым документом в рассматриваемой области. Ключевыми нормативными документами также являются: Основы государственной политики в области экологического развития России на период до 2030 года (утв. Президентом РФ от 30 апреля 2012 г.) ${ }^{45}$, Национальный проект «Экология» (утв. Президиумом Совета при

43 Указ Президента РФ от 01.04.1996 № 440 «О Концепции перехода Российской Федерации к устойчивому развитию» // http://www.consultant.ru/cons/ cgi/online.cgi?req=doc;base=EXP; $\mathrm{n}=233558 \# 0893137186763888$.

${ }^{44}$ Федеральный закон от 10.01.2002 № 7-Ф3 (ред. от 29.07.2018) «Об охране окружающей среды» // http://www.consultant.ru/cons/cgi/online.cgi?req= doc \&base $=$ LAW $\& n=301549 \&$ fld $=134 \& d s t=1000000001,0 \&$ rnd $=0.5121512642566695$ \#09260422738630374.

45 Утверждены основы государственной политики в области экологического развития России на период до 2030 года. Сайт Президента России // http:// www.kremlin.ru/events/president/news/15177. 
Президенте РФ по стратегическому развитию и национальным проектам от 24 декабря 2018 г.) ${ }^{46}$ и др.

Обязательства России по Парижскому соглашению предусматривают снижение выбросов парниковых газов к 2010 г. до 75 \% от уровня 1990 г. В 2016 г. объем выбросов парниковых газов российской экономикой по данным Международного агентства составил 1438,6 млн т, это 66,49 \% от уровня 1990 г. (от 2163,5 млн т) ${ }^{47}$. То есть достигнуто существенное снижение выбросов парниковых газов. Но исследователи отмечают, что при существующем уровне углеродоемкости российской экономики, гораздо более значительном, чем у развитых экономик мира, при сохранении данного показателя на уровне 2015 г. и умеренного роста ВВП, к 2030 г. объем выбросов может значительно превысить уровень 1990 г. ${ }^{48}$ Таким образом, при отсутствии прогресса в развитии программ энергоэффективности и энергосберегающих технологий, России сложно будет выполнить обязательства Парижского соглашения.

Выполнение Россией Парижского соглашения связано с рядом сложностей, так как в России существует значительное количество крупных промышленных городов, в которых сосредоточены крупнейшие металлургические, химические, добывающие производства (это такие города как Норильск, Череповец, Магнитогорск и др.) и существует технические и технологические ограничения по снижению вредных веществ.

Россия принимает важные шаги, направленные на ратификацию Парижских соглашений и подготовку условий для их выполнения. Так на законодательном уровне принят «План реализации

${ }^{46}$ Паспорт Национального проекта «Экология». Сайт Минприроды России// http://www.mnr.gov.ru/activity/directions/natsionalnyy_proekt_ekologiya/.

${ }^{47}$ Международное энергетическое агентство // https://webstore.iea.org/co2emissions-from-fuel-combustion-2018-highlights.

${ }^{48}$ Проект Федерального закона «О государственном регулировании выбросов парниковых газов и о внесении изменений в отдельные законодательные акты Российской Федерации» // Источник: https://regulation.gov.ru/projects/List/ AdvancedSearch\#kinds $=6 \&$ StartDate $=7.12 .2018 \&$ EndDate $=7.12 .2018 \& \mathrm{npa}=865211$; Степанова М.А., Гаврильева Т.Н. Российская климатическая политика после Парижского соглашения: перспективы северных регионов // Экономика Востока России. - 2018. - № 1 (09). - С. 97-106, с. 98. 
комплекса мер по совершенствованию государственного регулирования выбросов парниковых газов и подготовки к ратификации Парижского соглашения, принятого 12 декабря 2015 г. 21-й сессией Конференции Сторон Рамочной конвенции Организации Объединенных Наций об изменении климата», который был утвержден распоряжением Правительства Российской Федерации от 3 ноября 2016 г. № 2344-p ${ }^{49}$. План предусматривает оценку социальноэкономических последствий ратификации Парижского соглашения, на основе которой готовится доклад Президенту Российской Федерации о целесообразности ратификации Парижского соглашения. Доклад был представлен Минприроды России, которое «подготовило и внесло 28 февраля 2019 г. в Правительство РФ предложения с обоснованием целесообразности ратификации. Планируется, что процесс обсуждения завершиться в конце 2019 года к началу 25-й сессии Конференции Сторон РКИК ООН» ${ }^{50}$.

Ряд экспертов возражают против быстрой и неаргументированной ратификации договора, отмечая «недоказанность антропогенного влияния на изменение климата», но бизнес-сообщество в лице РСПП решило не возражать против ратификации Парижских соглашений, но при этом продвигать свой вариант концепции углеродного регулирования. В письме Минприроды РСПП настаивает, что «в РФ не должны реализовываться модели углеродного регулирования, связанные с дополнительной финансовой нагрузкой на базовые отрасли экономики, поскольку это приведет к снижению их конкурентоспособности и росту затрат промышленности и населения», а само регулирование «должно носить прозрачный, объективный и необременительный ха-

${ }^{49}$ План реализации комплекса мер по совершенствованию государственного регулирования выбросов парниковых газов и подготовки к ратификации Парижского соглашения, принятого 12 декабря 2015 г. 21-й сессией Конференции Сторон Рамочной конвенции Организации Объединенных Наций об изменении климата. Распоряжение Правительства Российской Федерации от 3 ноября 2016 г. № 2344-p.

${ }^{50}$ Официальный сайт Минприроды РФ// http://www.mnr.gov.ru/press/news/ minprirody_rossii_podgotovilo_i_vneslo_v_pravitelstvo_rf_predlozheniya_ s_obosnovaniem_tselesoobrazno/. 
рактер для российских компаний, стимулировать развитие отечественной экономики» ${ }^{51}$.

План предусматривает разработку концепции и механизмов регулирования выбросов парниковых газов в Российской Федерации, в том числе разработку мер финансовой поддержки и стимулирования ограничений выбросов таких газов, в частности предусмотрено: подготовка проекта плана мероприятий по реализации установленной указом Президента Российской Федерации цели ограничения выбросов парниковых газов к 2030 году; подготовка проекта федерального закона о государственном регулировании выбросов парниковых газов; разработку проекта стратегии долгосрочного развития с низким уровнем выбросов парниковых газов до 2050 года; разработку плана по сокращению выбросов парниковых газов в результате обезлесения и деградации лесов, усиления мер по сохранению, устойчивому управлению и увеличению накопления углерода в лесах; разработку модели государственного регулирования выбросов парниковых газов в Российской Федерации; разработку проекта национального плана адаптации к неблагоприятным изменениям климата; подготовку предложений об участии в международных финансовых механизмах по оказанию помощи развивающимся странам в смягчении последствий изменения климата и адаптации ${ }^{52}$.

План и документы разрабатываются и проходят экспертизу согласно принятому документу. Так в январе 2018 г. комиссия по законопроектной деятельности одобрила проект Федерального закона «О парниковых газах», до настоящего времени законопроект

51 Парижскому соглашению РСПП не мешает // газета «Коммерсантъ» № 13 от 25.01.2019, стр. 2// Официальный сайт газеты «Коммерсантъ»// https:// www.kommersant.ru/doc/3862151.

52 План реализации комплекса мер по совершенствованию государственного регулирования выбросов парниковых газов и подготовки к ратификации Парижского соглашения, принятого 12 декабря 2015 г. 21-й сессией Конференции Сторон Рамочной конвенции Организации Объединенных Наций об изменении климата. Распоряжение Правительства Российской Федерации от 3 ноября 2016 г. № 2344-p. 
не вступил в силу ${ }^{53}$. Целью закона является «создание условий для сокращения выбросов парниковых газов с учетом необходимости обеспечения экономического развития Российской Федерации на устойчивой основе и в соответствии с международными обязательствами» ${ }^{54}$. Проект закона определяет основные понятия в данной области, среди которых «парниковые газы» ${ }^{55}$, «выбросы парниковых газов», «инвентаризация выбросов парниковых газов», «государственный учет выбросов парниковых газов», «целевой показатель выбросов парниковых газов» и др. В Проекте определены Полномочия федеральных органов исполнительной власти в сфере государственного регулирования выбросов парниковых газов, среди которых: установление и распределение разрешений на выбросы парниковых газов хозяйствующим субъектам; утверждение методик количественного определения выбросов парниковых газов хозяйствующими субъектами; утверждение требований к проектам, направленным на сокращение выбросов и (или) увеличение поглощения парниковых газов; проведение государственного учета выбросов и поглощений парниковых газов ${ }^{56}$. Законом предусмотрена организация государственный учета парниковых газов, в т.ч. мони-

${ }^{53}$ Проект Федерального закона «О государственном регулировании выбросов парниковых газов и о внесении изменений в отдельные законодательные акты Российской Федерации» // Источник: https:/regulation.gov.ru/ projects $/$ List $/$ AdvancedSearch $\#$ kinds $=6 \&$ StartDate $=7.12 .2018 \&$ EndDate $=$ 7.12.2018\&npa $=865211$.

54 Проект Федерального закона «О государственном регулировании выбросов парниковых газов и о внесении изменений в отдельные законодательные акты Российской Федерации»// Источник: https://regulation.gov.ru/ projects $/$ List $/$ AdvancedSearch $\#$ kinds $=6 \&$ StartDate $=7.12 .2018 \&$ EndDate $=$ 7.12.2018\&npa=865211.

55 «парниковые газы - газообразные составляющие атмосферы как природного, так и антропогенного происхождения, которые поглощают и переизлучают инфракрасное излучение» // Источник: https:/regulation.gov.ru/ projects $/$ List $/$ AdvancedSearch $\#$ kinds $=6 \&$ StartDate $=7.12 .2018 \&$ EndDate $=$ 7.12.2018\&npa=865211.

${ }^{56}$ С т. 5. Проект Федерального закона «О государственном регулировании выбросов парниковых газов и о внесении изменений в отдельные законодательные акты Российской Федерации» // Источник: https:/regulation.gov.ru/projects/List/ AdvancedSearch \#kinds $=6 \&$ StartDate $=7.12 .2018 \&$ EndDate $=7.12 .2018 \& \mathrm{npa}=865211$. 
торинг и отчетность о выбросах парниковых газов ${ }^{57}$. Важным аспектом закона является разработка механизмов экономического стимулирования деятельности по сокращению выбросов парниковых газов и (или) увеличению их поглощения (ст. 11), в которой предусматриваются такие меры как применение ускоренной амортизации основных производственных фондов, предназначенных для деятельности по сокращению выбросов парниковых газов и (или) увеличению их поглощения, а также предоставление налоговых льгот ${ }^{58}$.

Минприроды России активно разрабатывает нормативные акты, направленные на реализацию Парижских соглашений, среди которых:

- в 2015 г. утверждены методические указания и руководство по количественному определению объемов выбросов парниковых газов организациями, осуществляющими хозяйственную и иную деятельность в Российской Федерации ${ }^{59}$;

- в 2018 г. приняты такие документы как: Приказ Минприроды России от 11.10.2018 № 509 «Об утверждении формы декларации о воздействии на окружающую среду и порядка ее заполнения, в том числе в форме электронного документа, подписанного усиленной квалифицированной электронной подписью» ${ }^{60}$; Приказ

${ }^{57}$ Ст. 7. Проект Федерального закона «О государственном регулировании выбросов парниковых газов и о внесении изменений в отдельные законодательные акты Российской Федерации» // Источник: https://regulation.gov.ru/projects/List/ AdvancedSearch\#kinds $=6 \&$ StartDate $=7.12 .2018 \&$ EndDate $=7.12 .2018 \& \mathrm{npa}=865211$.

${ }^{58}$ С т. 11. Проект Федерального закона «О государственном регулировании выбросов парниковых газов и о внесении изменений в отдельные законодательные акты Российской Федерации» // Источник: https://regulation.gov.ru/projects/List/ AdvancedSearch\#kinds $=6 \&$ StartDate $=7.12 .2018 \&$ EndDate $=7.12 .2018 \&$ npa $=865211$.

59 Приказ Минприроды России от 30.06.2015 № 300 «Об утверждении методических указаний и руководства по количественному определению объема выбросов парниковых газов организациями, осуществляющими хозяйственную и иную деятельность в Российской Федерации» (Зарегистрировано в Минюсте России 15.12.2015 № 40098) // http://www.consultant.ru/cons/cgi/online.cgi?req=doc\&base=LAW\&n= $190838 \&$ fld $=134 \& d s t=1000000001,0 \& \mathrm{rnd}=0.24185131508949387 \# 09545703212195382$.

${ }^{60}$ Приказ Минприроды России от 11.10.2018 № 509 «Об утверждении формы декларации о воздействии на окружающую среду и порядка ее заполнения, в том числе в форме электронного документа, подписанного усиленной квалифицированной электронной подписью» (Зарегистрировано в Минюсте России 10.12.2018 № 52926). 
Минприроды России от 11.10.2018 № 510 «Об утверждении формы заявки на получение комплексного экологического разрешения и формы комплексного экологического разрешения» ${ }^{61}$.

Обсуждение и ратификация Парижского соглашения в России завершилось в 2019 г.: 23 сентября 2019 г., в день проведения саммита ООН по борьбе с климатическими изменениями, премьер-министр РФ Д.А. Медведев подписал постановление правительства, связанное с принятием Россией Парижского соглашения по климату ${ }^{62}$. Таким образом Россия присоединилась к Парижским климатическим соглашениям 2015 г. и «стала одним из последних крупных эмитентов парниковых газов, ставших полноправным участником нового климатического договора, пришедшего на смену Киотскому протоколу» ${ }^{63}$. Россия взяла на себя обязательства сократить выбросы углекислого газа на $30 \%$ по сравнению с 1990 г. ${ }^{64}$. Министр иностранных дел РФ Сергей Лавров отметил, что «протяжении 35 лет Россия будет удерживать выбросы на одном уровне, в значительной степени компенсируя рост эмиссии в других странах и регионах мира. Планируем достичь этой цели путем внедрения новых энергосберегающих технологий, повышения энергоэффективности экономики, развития возобновляемых и чистых источников энергии» ${ }^{65}$.

Таким образом Россия активно участвует в международных процессах регулирования и реализации соглашений, направленных

${ }^{61}$ Приказ Минприроды России от 11.10.2018 № 510 «Об утверждении формы заявки на получение комплексного экологического разрешения и формы комплексного экологического разрешения» (Зарегистрировано в Минюсте России 10.12.2018 № 52927).

${ }^{62}$ Информационный портал «Будущее России. Национальные проекты» / / https://futurerussia.gov.ru/nacionalnye-proekty/srocno-medvedev-podpisalpostanovlenie-svazannoe-s-prinatiem-rf-parizskogo-soglasenia-po-klimatu.

${ }^{63}$ Давыдова А. Россия согласилась на Парижский климат. Коммерсанть № $173,24.09 .2019$.

${ }^{64}$ Вестник отделения наук о Земле РАН // https://onznews.wdcb.ru/images/ news16/ info_160307.html.

${ }^{65}$ РФ ратифицирует Парижское соглашение по климату в I квартале 2019 года. Информационное агентство Интерфакс // https://www.interfax.ru/russia/587799. 
на снижение антропогенного вредного воздействия на окружающую среду. Но при этом существуют риски «трансформации традиционных нефтегазовых экспортных рынков России» ${ }^{66}$, а также различие в оценках выгод и издержек для российской экономики при реализации Парижских соглашений.

Исследователи ${ }^{67}$ опасаются следующих негативных последствий для российской экономики:

\section{1) возможный рост себестоимости углеродного топ-} лива, а также продукции отраслей, в затратах которых высока доля статьи «топливо и энергия», таких как металлургия, производство удобрений, цемента ввиду введения финансовых и налоговых обременений.

Отметим, что по запасам угля, который как источник энергии признан оказывающим вредное воздействие на окружающую среду ${ }^{68}$, Россия занимает второе место в мире (см. таблицу 1). «Сжигание угля ведет к образованию больших количеств двуокиси углерода, серы, ртути и других вредных веществ. В этом отношении уголь - самый худший из всех видов органического топлива», - отмечают специалисты НИИ малотоннажных химических продуктов и реактивов Уфимского государственного нефтяного технического университета ${ }^{69}$. Также по данным аналитиков независимой информационно-консалтинговой компании Enerdata в 2017 году «интенсивность выбросов СО2 в России была на 80 \% выше среднего показателя в мире» ${ }^{70}$.

${ }^{66}$ Степанова М.А., Гаврильева Т.Н. Российская климатическая политика после Парижского соглашения: перспективы северных регионов // Экономика Востока России. - 2018. - № 1 (09). - С. 97-106, с. 101.

${ }^{67}$ Степанова М.А., Гаврильева Т.Н. Российская климатическая политика после Парижского соглашения: перспективы северных регионов // Экономика Востока России. - 2018. - № 1 (09). - С. 97-106, с. 101;

${ }^{68}$ В 2017 году доля угля в выбросах $\mathrm{CO}_{2}$ составила 45 \% (1 место). Источник: https://yearbook.enerdata.ru/co2-fuel-combustion/CO2-emissions-data-fromfuel-combustion.html.

${ }^{69}$ Рахманкулов Д.Л., Николаева С.В., Латыпова Ф.Н., Вильданов Ф.Ш., Шавшукова С.Ю. Мировые запасы угля и перспективы его использования // Башкирский химический журнал. 2009. Том 16. № 2. С. 21-28, с. 24.

${ }^{70} \mathrm{https}$ //yearbook.enerdata.ru/co2-fuel-combustion/world-CO2-intensity.html. 
Таблииа 1

\section{Страны мира с крупнейшими запасами угля}

\begin{tabular}{|c|c|c|}
\hline Страна & $\begin{array}{l}\text { Запасы уг- } \\
\text { ля, млрд т }\end{array}$ & Характеристика \\
\hline США & 237,3 & $\begin{array}{l}\text { Залежи каменного и бурого угля находятся на бла- } \\
\text { гоприятной глубине (от } 450 \text { м на Западе США и до } \\
900 \text { м в Аппалачском бассейне). Месторасположе- } \\
\text { ния часто имеют рядом крупного потребителя } \\
\text { (ТЭЦ), что обеспечивает экономическую эффек- } \\
\text { тивность добычи. } \\
\text { Более } 85 \% \text { всех запасов угля Соединенных Шта- } \\
\text { тов сосредоточены в семи направлениях: Кентук- } \\
\text { ки, Иллинойс, Вайоминг, Пенсильвания, Колорадо, } \\
\text { Алабама, Техас. } \\
\text { США находится на } 1 \text { месте как по показателям за- } \\
\text { пасов, так и добычи угля }\end{array}$ \\
\hline Россия & 157 & $\begin{array}{l}\text { Это приближенные данные, поскольку недостаточно } \\
\text { разведаны возможные запасы ресурса. Наиболее ак- } \\
\text { тивно разрабатываются следующие месторождения: } \\
\text { Печорское, Канско-Аченское, Кузнецкое, Южно- } \\
\text { Якутское. Много месторождений, разработка которых } \\
\text { экономически неэффективна ввиду неблагоприятного } \\
\text { экономико-геграфического расположения. } 70 \text { \% за- } \\
\text { пасов углей - высокого качества. Запасов бурого угля } \\
\text { больше, чем каменного. По оценкам экспертов Россия } \\
\text { имеет треть мировых запасов угля (4 трлн Т) }\end{array}$ \\
\hline Китай & 114,5 & $\begin{array}{l}\text { Не все запасы угля разведаны, по оценкам, общее } \\
\text { количество углей может составлять } 781 \text { млрд т. } \\
97 \% \text { запасов - каменные угли. Крупнейший } \\
\text { угольный бассейн - Шаньсинский. } \\
\text { Коксы располагаются в бассейнах Великой Китай- } \\
\text { ской равнины, Янцзы, Ганьцзян, Датун, Хэган- } \\
\text { Шуанъяшань и прочих точках. } 90 \text { \% добываемых уг- } \\
\text { лей потребляется энергетической промышленностью }\end{array}$ \\
\hline $\begin{array}{c}\text { Австра- } \\
\text { лия }\end{array}$ & 76,4 & $\begin{array}{l}\text { По оценкам, запасов угля хватит для разработки на } \\
240 \text { лет. Наиболее крупные месторождения нахо- } \\
\text { дятся на Востоке материка. Имеютя крупные за- } \\
\text { пасы коксующихся углей высокого качества, кото- } \\
\text { рые располагаются преимущественно в штатах Но- } \\
\text { вый Южный Уэльс и Квинсленд. Запасы бурого } \\
\text { угля размещены на юго-востоке страны. Более } \\
80 \% \text { угля идет на обслуживание электроэнергети- } \\
\text { ки. Это вдвое больше мирового показателя. Мест- } \\
\text { ные ТЭС отличаются высокой экологичностью }\end{array}$ \\
\hline
\end{tabular}


Окончание таблищы 1

\begin{tabular}{|c|c|c|}
\hline Страна & $\begin{array}{l}\text { Запасы уг- } \\
\text { ля, млрд т }\end{array}$ & Характеристика \\
\hline Индия & 60,6 & $\begin{array}{l}\text { Индия располагает } 9 \text { \% запасов угля. Он является } \\
\text { основным источником сырья для производства } \\
\text { энергии. } \\
\text { Наиболее важные месторождения расположены } \\
\text { на северо-востоке страны. Качество угля низкое. } \\
\text { Используется в электроэнергетике (преимущест- } \\
\text { венно), а также в металлургии, цементной и } \\
\text { транспортной промышленностях, в быту }\end{array}$ \\
\hline $\begin{array}{c}\text { Герма- } \\
\text { ния }\end{array}$ & 40,7 & $\begin{array}{l}\text { Уголь высокого качества. Наибольшее количество } \\
\text { запасов сосредоточено на территории федеральных } \\
\text { земель Северный Рейн-Вестфалия и Саар, Саксо- } \\
\text { нии, Бранденбурге, а также Северной Рейн- } \\
\text { Вестфалии. В настоящее время добыча угля нерен- } \\
\text { табельна, существуют дотации государства }\end{array}$ \\
\hline Украин & 33,9 & $\begin{array}{l}\text { Обладает } 4 \text { \% мировых запасов угля. В основном за- } \\
\text { пасы каменного угля сосредоточены в Донецком и } \\
\text { Львовско-Волынском бассейнах, бурого - в Днеп- } \\
\text { ровском. При этом } 98 \text { \% каменного угля находится в } \\
\text { Доценком бассейне, } 2 \text { \% - во Львовско-Волынском. } \\
\text { Уголь расположен на достаточно большой глубине } \\
\text { (1-1,3 км) и содержит газ, что делает добычу опас- } \\
\text { ной из-за повышенной угрозы взрыва }\end{array}$ \\
\hline
\end{tabular}

Примечание. Источник: составлено авторами по https:/vivareit.ru/stranylidery-po-zapasam-uglya/.

Несмотря на высокие экологические риски применения угля, как отмечают эксперты, «в дальнейшем уголь по-прежнему будет одним из основных энергоносителей в топливно-энергетическом балансе восточных регионов (России - $A)$. Наиболее перспективным с позиций экономики и экологии представляется создание промышленных кластеров на базе месторождений угля» ${ }^{71}$. В связи с этим особое значение необходимо уделять разработке инновационных экологических проектов, способных минимизиро-

${ }^{71}$ Соколов А.Д., Такайшвили Л.Н. Оценка ресурсов угля восточных регионов России для строительства угольных электростанций // Вестник Иркутского государственного технического университета. 2018. Т. 22. № 7. С. 155-163. DOI: 10.21285/1814-3520-2018-7-155-163., c. 155. 
вать негативное влияние на окружающую среду, так как «экологические аспекты широкомасштабного развития угледобычи ... требуют основательной проработки» ${ }^{72}$.

При введении платы за выбросы парниковых газов необходимо просчитывать последствия для развития российских отраслей. Эксперты предупреждают, что, если выплаты составят более 1,0% ВВП, это нанесет значительный ущерб экономике ${ }^{73}$. Такая ситуация касается стран, в структуре экспорта преобладают продукция ТЭК, черные и цветные металлы, крупнотоннажная химическая продукция, цемент и т. п., а энергетика основана на использовании ископаемого топлива, и к таким странам относится Россия (см. таблицу 2). Для рассматриваемых сценариев ввода углеводородного сбора расчеты показывают следующее: при ставке 15 долл. США / т экв. $\mathrm{CO}_{2}$ ежегодные выплаты составят 42 млрд долл. или 3,2-4,1 \% ВВП; при ставке 35 долл. США / т экв. $\mathrm{CO}_{2}$ объем выплат составит 7,5-9 \% ВВП ${ }^{74}$.

Наиболее серьезный ущерб составит для таких отраслей как нефтегазовая отрасль, электро- и теплогенерация, транспорт, АПК, металлургия, производство азотных удобрений и цемента. Оценка ущерба: до 75 \% выручки, и до $615 \% \mathrm{EBITDA}^{75}$.

${ }^{72}$ Соколов А.Д., Такайшвили Л.Н. Оценка ресурсов угля восточных регионов России для строительства угольных электростанций // Вестник Иркутского государственного технического университета. 2018. Т. 22. № 7. С. 155-163. DOI: 10.21285/1814-3520-2018-7-155-163., c. 162.

${ }^{73}$ Краткое содержание и основные положения доклада «Риски реализации Парижского климатического соглашения для экономики и национальной безопасности» / Институт проблем естественных монополий. - Москва, 2016, 22 c., c. 6.

${ }^{74}$ Краткое содержание и основные положения доклада «Риски реализации Парижского климатического соглашения для экономики и национальной безопасности» / Институт проблем естественных монополий. - Москва, 2016, 22 c., c. 8.

${ }^{75}$ Краткое содержание и основные положения доклада «Риски реализации Парижского климатического соглашения для экономики и национальной безопасности» / Институт проблем естественных монополий. - Москва, 2016, 22 c., c. 8. 


\section{Структура экспорта России в 2018 году}

\begin{tabular}{|l|c|}
\hline \multicolumn{1}{|c|}{ Статья экспорта } & Вес в структуре экспорта, \% \\
\hline Топливно-энергетические товары & 63,7 \\
\hline Металлы и изделия из них & 9,9 \\
\hline Продукция химпрома & 6,1 \\
\hline Машины и оборудование & 6,5 \\
\hline $\begin{array}{l}\text { Продовольственные товары и сырье для их } \\
\text { производства }\end{array}$ & 5,5 \\
\hline Лесоматериалы и бумажные изделия & 3,1 \\
\hline Иные товары & 5,2 \\
\hline
\end{tabular}

Примечание. Источник: https://www.kubdeneg.ru/eksport-import-rf-2019obemy-struktura-tovary/.

2) ведущие страны мира значительное внимание уделяют развитию альтернативное энергетики и увеличению доли возобновляемых источников энергии (ВИЭ) при производстве новых мощностей. Для стран, зависящих от импорта топлива, стран, с низкой себестоимостью производства ВИЭ, такая стратегия экономически оправдана и целесообразна. Так, доля возобновляемых источников в производстве электричества в 2017 г. в Норвегии составляла 97,6 \%, в Колумбии - 86,8 \%, в Новой Зеландии $-81,4$ \%, в Бразилии - 79,7 \%, в Канаде - 64,7 \%, в Швеции $-57,5 \%{ }^{76}$. В странах с наибольшими запасами угля эта доля гораздо ниже: так в 2017 г. в США она составила 17,66 \%, в России - 17,5\%, в Китае - 25,97 \% , в Австралии - 14,95\%, в Индии $-16,29 \%$, в Германии - 33,98 \%, в Украине - 7,86 \% (см. таблицу 3$)^{77}$. Отметим, что в российской экономике доля возобновляемых источников в производстве электричества в России менялась незначительно: 15,3 \% в 1990 г. и 17,5 \% в 2017 г. (см. рис. 2).

${ }^{76}$ Данные независимой информационно-консалтинговой компании Enerdata https://yearbook.enerdata.ru/renewables/renewable-in-electricity-productionshare.html.

77 Данные независимой информационно-консалтинговой компании Enerdata // https://yearbook.enerdata.ru/renewables/renewable-in-electricity-productionshare.html. 


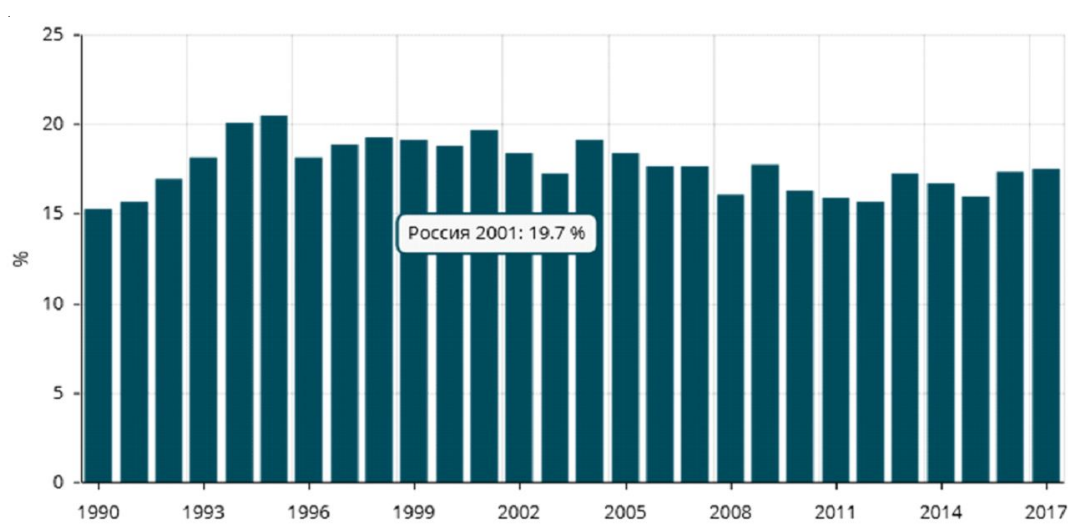

Рис. 2. Доля возобновляемых источников в производстве электричества в России (1990-2017)

Примечание. Источник: данные независимой информационно-консалтинговой компании Enerdata // https://yearbook.enerdata.ru/renewables/renewable-inelectricity-production-share.html.

Снижение затрат и политика стимулирования ВИЭ в развитых и развивающихся странах способствует их развитию. «Солнечные станции отвечают за $20 \%$ дополнительной выработки электроэнергии в 2017 году, а ветряные - за 30\%. Возобновляемые источники энергии теперь покрывают $1 / 3$ энергетической микса в Европе, 1/4 в Китае и 1/6 в Соединенных Штатах, Индии и Японии», - отмечают независимые эксперты из Enerdate ${ }^{78}$.

В России ввиду высоких затрат на ВИЭ и особенностей климата, отсутствию комплексной поддержки ВИЭ, по оценкам специалистов, развитие ВИЭ в ближайшие 5-7 лет ожидается только в отдельных районах ${ }^{79}$.

И стимулирования экологически ответственных производств должны быть обоснованными и найти свое воплощение в практической деятельности.

78 Данные независимой информационно-консалтинговой компании Enerdata https://yearbook.enerdata.ru/renewables/renewable-in-electricity-production-share.html.

${ }^{79}$ Степанова М.А., Гаврильева Т.Н. Российская климатическая политика после Парижского соглашения: перспективы северных регионов // Экономика Востока России. - 2018. - № 1 (09). - С. 97-106, с. 101. 


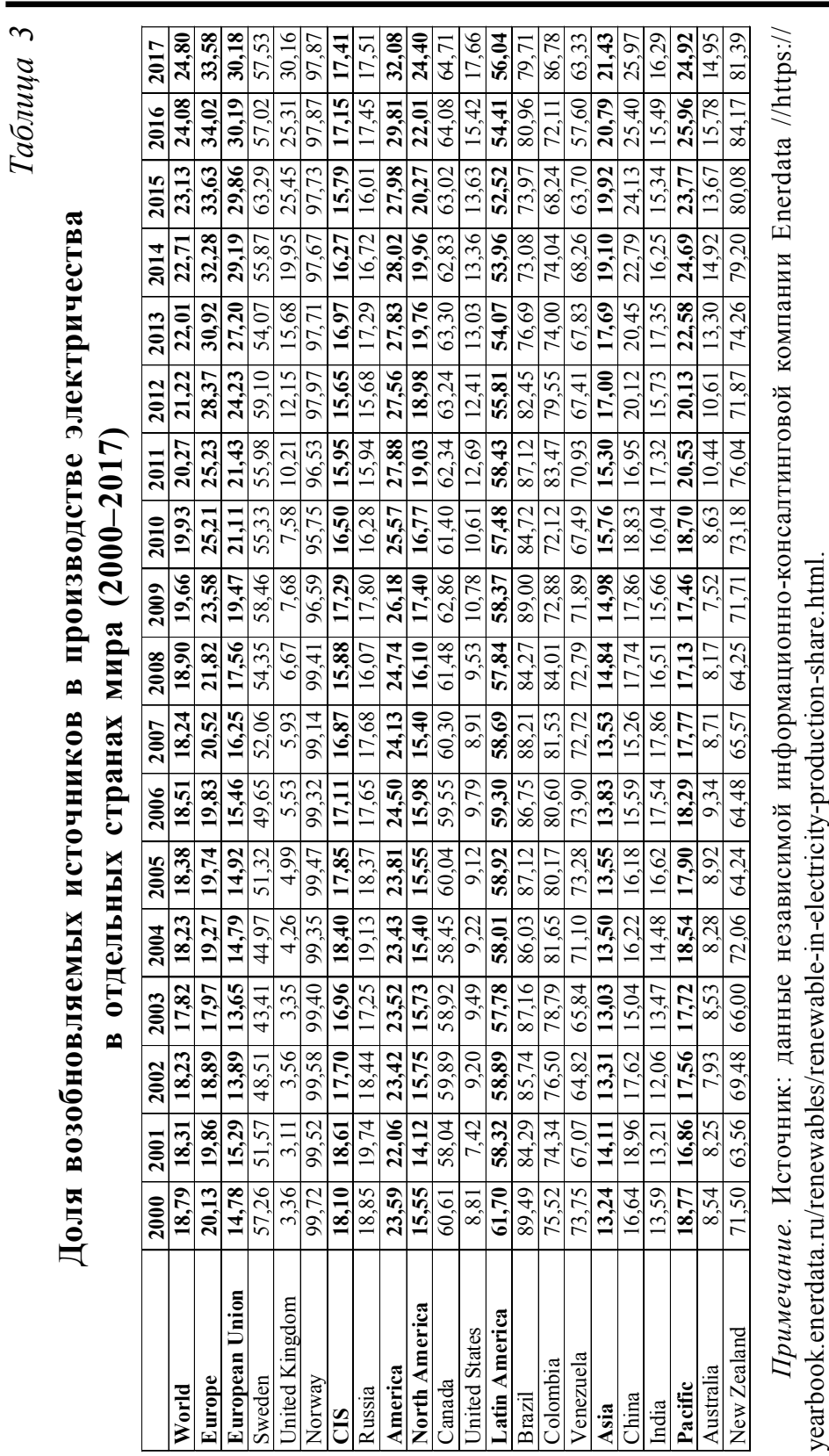


3) Увеличение рисков технологического отставания российской экономики. Парижские соглашения стимулируют развитие инновационных технологических инноваций в области «зеленой экономике», открывают новые возможности для компаний-лидеров в данных сферах. С учетом технологического отставания России даже в традиционных технологических направлениях ${ }^{80}$, риски отставания российской экономики только углубляются. Внедрение экологических сборов, штрафов и т.п. мер необходимо обосновывать экономически, поскольку может привести к росту затрат добывающих компаний и снижению их конкурентоспособности, следовательно, снижению инвестиционного и кредитного рейтингов. Декларируемые в российских нормативных актах разработка мер поддержки.

4) Высокая неопределенность в понимании механизмов и направлений дальнейшей реализации Парижского соглашения, связанная с таким факторами как: а) отсутствие четкой позиции ключевых игроков (таких как США), б) активная роль бизнессообществ, которые обращают внимание на риски роста издержек бизнеса, потерю конкурентоспособности, сокращение числа рабочих мест и доходов работников; в) наличие антироссийских санкций, изза которых оказались «замороженными» многие экологические проекты, реализуемые Россией совместно с Всемирным банком ${ }^{81}$. Как пример таких рисков отметим, что оборудование для СЭС и ВЭС не производится в России в достаточных объемах ${ }^{82}$, следовательно при

${ }^{80}$ «Сдерживающими факторами переориентации сырьевой базы производства жидких топлив с нефти на уголь до настоящего времени являлись, в основном, экономические и экологические факторы, которые удалось устранить применением разработанной в России уникальной каталитической системы, что позволило существенно снизить технологическое давление, и привлечением атомной энергетики». Цит по: Рахманкулов Д.Л., Николаева С.В., Латыпова Ф.Н., Вильданов Ф.Ш., Шавшукова С.Ю. Мировые запасы угля и перспективы его использования // Башкирский химический журнал. 2009. Том 16. № 2. С. 21-28, с. 27.

${ }^{81}$ Степанова М.А., Гаврильева Т.Н. Российская климатическая политика после Парижского соглашения: перспективы северных регионов // Экономика Востока России. - 2018. - № 1 (09). - С. 97-106, с. 101.

${ }^{82}$ Краткое содержание и основные положения доклада «Риски реализации Парижского климатического соглашения для экономики и национальной безопасности» / Институт проблем естественных монополий.. - Москва, 2016, 22 с., с. 10. 
активном развитии ВИЭ выгоды получат зарубежные компании, а также возможен отказ от сервисных работ при введении каких-либо антироссийских санкций.

Таким образом Россия активно участвует в международных процессах регулирования и реализации соглашений, направленных на снижение антропогенного вредного воздействия на окружающую среду. Но при этом существуют риски «трансформации традиционных нефтегазовых экспортных рынков России» ${ }^{83}$, а также различие в оценках выгод и издержек для российской экономики при реализации Парижских соглашений.

Механизмы реализации Парижских соглашений можно разделить на две группы:

А) Жесткие. Они включают следующие направления и требуют для реализации значительных инвестиций ${ }^{84}$ :

- введение углеродного сбора, организация систем торговли квотами;

- строительство «безуглеродных» станций (СЭС, ВЭС, АЭС, ГЭС);

- установка оборудования по улавливанию и хранению $\mathrm{CO}_{2}$.

Следует учитывать, что жесткие меры окажут существенное влияние на развитие целых отраслей экономики, которые для России являются стратегическими. Отдельные специалисты считают, что «природоохранная повестка может активно использоваться в международной конкурентной борьбе» ${ }^{85}$.

Б) Мягкие. Данные меры не требуют значительных финансовых затрат и отличаются быстрыми сроками окупаемости. К ним относят:

${ }^{83}$ Степанова М.А., Гаврильева Т.Н. Российская климатическая политика после Парижского соглашения: перспективы северных регионов // Экономика Востока России. - 2018. - № 1 (09). - С. 97-106, с. 101.

${ }^{84}$ Краткое содержание и основные положения доклада «Риски реализации Парижского климатического соглашения для экономики и национальной безопасности» / Институт проблем естественных монополий. - Москва, 2016, 22 с., с. 5.

${ }^{85}$ Аналитический доклад «Риски реализации Парижского климатического соглашения для экономики и национальной безопасности» / Институт проблем естественных монополий. - Москва, 2016, 114 с., с. 13. 
- повышение энергоэффективности и энергосбережения в российской экономике;

- развитие комбинированной выработки электро- и теплоэнергии на ТЭЦ;

- стимулирование лесовосстановительных работ;

- мероприятия по ограничению выбросов парниковых газов от АПК;

- информирование, образование;

- адаптация методик учета парниковых газов к российским условиям.

Выводы. Российская Федерация активно участвует в реализации международных соглашений по предотвращению изменений климата и снижению антропогенного воздействия на окружающую среду. К настоящему времени разработаны такие основополагающие нормативные акты в области охраны окружающей среды как:

- Федеральный закон от 10.01.2002 № 7-Ф3 (ред. от 29.07.2018) «Об охране окружающей среды»;

- Стратегия экологической безопасности Российской Федерации на период до 2025 года. Указ Президента России № 176 от 19.04.2017»;

- Основы государственной политики в области экологического развития России на период до 2030 года (утв. Президентом РФ от 30 апреля 2012 г.);

- Национальный проект «Экология» (утв. Президиумом Совета при Президенте РФ по стратегическому развитию и национальным проектам от 24 декабря 2018 г.);

- Государственная программа Российской Федерации «Экономическое развитие и инновационная экономика»;

- Приказ Минприроды России от 11.10.2018 № 509 «Об утверждении формы декларации о воздействии на окружающую среду и порядка ее заполнения, в том числе в форме электронного документа, подписанного усиленной квалифицированной электронной подписью» (Зарегистрировано в Минюсте России 10.12.2018 № 52926);

- Приказ Минприроды России от 11.10.2018 № 510 «Об утверждении формы заявки на получение комплексного экологи- 
ческого разрешения и формы комплексного экологического разрешения» (Зарегистрировано в Минюсте России 10.12.2018 № 52927);

- Приказ Минприроды России от 30.06.2015 № 300 «Об утверждении методических указаний и руководства по количественному определению объема выбросов парниковых газов организациями, осуществляющими хозяйственную и иную деятельность в Российской Федерации» (Зарегистрировано в Минюсте России 15.12.2015 № 40098);

- Проект Федерального закона «О государственном регулировании выбросов парниковых газов и о внесении изменений в отдельные законодательные акты Российской Федерации»;

- План реализации комплекса мер по совершенствованию государственного регулирования выбросов парниковых газов и подготовки к ратификации Парижского соглашения, принятого 12 декабря 2015 г. 21-й сессией Конференции Сторон Рамочной конвенции Организации Объединенных Наций об изменении климата. Распоряжение Правительства Российской Федерации от 3 ноября 2016 г. № 2344-p.

В этих документах определены основные принципы охраны окружающей среды, предусматривается разработка концепции и механизмов регулирования выбросов парниковых газов в Российской Федерации, а также механизмов экономического стимулирования деятельности по сокращению выбросов парниковых газов и (или) увеличению их поглощения.

Вместе с тем эксперты предупреждают о рисках быстрой и неаргументированной ратификации Парижского договора для российской экономики, о возможных негативных последствиях для ряда отраслей при введении жестких мер, а именно:

- увеличение себестоимости углеродного топлива и роста затрат на производство в отраслях, в которых высока доля затрат на топливо и энергию (металлургия, производство удобрений, цементная отрасль);

- ограниченную экономическую эффективность развития альтернативной электроэнергетики, возобновляемых источников энергии; 
- увеличение рисков технологического отставания российской экономики;

- высокая неопределенность в понимании механизмов и направлений дальнейшего развития Парижских соглашений

«Мягкие» меры реализации Парижских соглашений могут, напротив, одновременно привести к снижению антропогенной нагрузки на окружающую среду и улучшить экономические показатели Российской экономики. Так, российская экономика в настоящее время характеризуется высокой энергоэффективностью экономики. Правительством Российской Федерации от 15.04.2014 г. № 316 утверждена государственная программа «Экономическое развитие и инновационная экономика», одной из подпрограмм которой является программа «Энергосбережение и повышение экономической эффективности» ${ }^{86}$, целевое назначение которой - «снижение энергоемкости экономики Российской Федерации» ${ }^{87}$.

В настоящее время действует редакция программы от 29.03.2019 г. Задачами подпрограммы являются: развитие институциональной среды как комплекса правовых, организационно-управленческих, финансовых и материально-технических условий, стимулирующих и обеспечивающих возникновение и реализацию инициатив и мероприятий в области энергосбережения и повышения энергетической эффективности; стимулирование привлечения внебюджетных инвестиций в реализацию мероприятий (проектов) в области энергосбережения и повышения энергетической эффективности; формирование среды

86 Паспорт подпрограммы Д «Энергосбережение и повышение энергетической эффективности» государственной программы Российской Федерации «Экономическое развитие и инновационная экономика» (введен Постановлением Правительства РФ от 29.03.2019 № 379) // http://www.consultant.ru/document/ cons_doc_LAW_162191/9ca0eadc6bfc50b5426991d690cc8f12fbb13a2e/.

${ }^{87}$ Паспорт подпрограммы Д «Энергосбережение и повышение энергетической эффективности» государственной программы Российской Федерации «Экономическое развитие и инновационная экономика» (введен Постановлением Правительства РФ от 29.03.2019 № 379) // http://www.consultant.ru/document/ cons_doc_LAW_162191/9ca0eadc6bfc50b5426991d690cc8f12fbb13a2e/. 
комплексной информационной поддержки энергосбережения и повышения энергетической эффективности на всех уровнях структур государственного управления и общества ${ }^{88}$.

Объем бюджетных ассигнований на реализацию подпрограммы за счет средств федерального бюджета составляет 389 293,2 тыс. рублей, в том числе: на 2019 год - 62 011,6 тыс. рублей; на 2020 год - 63 882,4 тыс. рублей; на 2021 год - 65 849,8 тыс. рублей; на 2022 год - 65849,8 тыс. рублей; на 2023 год 65 849,8 тыс. рублей; на 2024 год - 65849,8 тыс. рублей ${ }^{89}$.

Стимулирование внедрения энергосберегающих технологий позволит уменьшить нагрузку на окружающую среду и повысить конкурентоспособность российской экономики.

Спецификой российского варианта развития экологических программ является развитие лесного хозяйства с целью повышения поглощения парниковых газов. Российские леса составляют около 20 \% всех лесов мира и вносят значительный вклад в сокращение выбросов парниковых газов. Необходимо проводить рациональную государственную политику, направленную контроль за их вырубкой и восстановление лесов. Специалисты отмечают необходимость корректировки действующих методик учета парниковых газов, которые не учитывают поглощающий эффект российских лесов ${ }^{90}$. Также необходимо учитывать роль океана в поглощении парниковых газов: согласно исследованиям, мировой

${ }^{88}$ Паспорт подпрограммы Д «Энергосбережение и повышение энергетической эффективности» государственной программы Российской Федерации «Экономическое развитие и инновационная экономика» (введен Постановлением Правительства РФ от 29.03.2019 № 379) // http://www.consultant.ru/document/ cons_doc_LAW_162191/9ca0eadc6bfc50b5426991d690cc8f12fbb13a2e/.

${ }^{89}$ Паспорт подпрограммы Д “Энергосбережение и повышение энергетической эффективности” государственной программы Российской Федерации “Экономическое развитие и инновационная экономика” (введен Постановлением Правительства РФ от 29.03.2019 № 379) // http://www.consultant.ru/document/ cons_doc_LAW_162191/9ca0eadc6bfc50b5426991d690cc8f12fbb13a2e/.

${ }^{90}$ Краткое содержание и основные положения доклада «Риски реализации Парижского климатического соглашения для экономики и национальной безопасности» / Институт проблем естественных монополий. - Москва, 2016, 22 c., c. 18. 
океан поглощает около 30 \% парниковых газов. Поэтому необходимо учитывать в методиках учет поглощения парниковых газов в экономической зоне или территориальных водах России.

Таким образом в стратегии развития «зеленой экономики» в России необходимо учитывать специфику развития всей экономики России, особенностей ее климата, наличие и качество природных ресурсов, качество существующей технологической платформы, внешние и внутренние политические факторы. 


\section{ГЛАВА 2. СОВЕРШЕНСТВОВАНИЕ МЕТОДОЛОГИИ И МЕТОДИКИ ОЦЕНКИ ЭКОЛОГО-ЭКОНОМИЧЕСКОГО РАЗВИТИЯ РЕГИОНОВ}

\section{1. Анализ существующих подходов к оценке эколого-экономической деятельности регионов}

Активизация развития «зеленой» экономики требует разработки соответствующей системы экономических механизмов и инструментов, увеличения инвестиций в охрану окружающей среды и «зеленые» технологии. В материалах третьей международной конференции по финансированию развития говорится: «мировые потребности в инвестициях в инфраструктуру - водоснабжение, сельское хозяйство, телекоммуникации, энергетику, транспорт, здания, промышленность и лесное хозяйство - составляют от 5 до 7 трлн долл. США в год» ${ }^{1}$. Но в условиях ограниченности и нерационального распределения финансовых ресурсов необходимо выделить приоритеты инвестирования и стимулирования экологических проектов и программ и учитывать множественные эффекты проектов с точки зрения максимального учета интересов инвесторов, потребителей, региона.

Для характеристики устойчивого развития разрабатываются системы индикаторов, которые позволяют дать адекватную оценку используемым средствам и уровню достижения целей, проводить эффективный мониторинг и осуществлять управление эколого-экономической политикой регионов.

В резолюции, принятой Генеральной ассамблеей ООН 25 сентября 2015 г. «Повестка дня в области устойчивого развития на

${ }^{1}$ Информационные материалы третьей международной конференции по финансированию развития // http://www.un.org/sustainabledevelopment/wpcontent/uploads/2015/07/FFD-Press-Kit-Russian-ONLINE.pdf, c. 5. 
период до 2030 года» поставлены 17 целей и 169 задач в области устойчивого развития. В документе подчеркивается важность не только экономического развития, но и экологического устойчивого развития: «Мы преисполнены решимости обеспечить, чтобы все люди могли жить в условиях процветания и благополучия, и чтобы экономический, социальный и технический прогресс продолжался в гармонии с природой ${ }^{2}$. Постановка целей и задач требует разработки индикаторов устойчивого развития для мониторинга и оценки эффективности управленческих решений.

Важность разработки индикаторов устойчивого развития отмечает проф. С.Н. Бобылев (МГУ): «Комплекс таких индикаторов - показателей и критериев - должен играть ключевую роль в описании (диагностике) состояния системы «природа - хозяйство население»... Пока ни о полноте комплекса индикаторов устойчивого развития, ни о достаточной точности их исчисления говорить рано...» .

В настоящее время наиболее широко известные экономические индикаторы на уровне макро- и мезоэкономики - это такие индикаторы как ВВП - валовой внутренний продукт, ВНД - валовой национальный продукт, ВРП - валовой региональный продукт и т. п. Данные индикаторы подвергаются критике со стороны многих экспертов ввиду того, что данные показатели отражают исключительно экономические аспекты жизни, но не отражают действительную удовлетворенность индивидов от жизни. Кроме того, данные показатели не учитывают, что производство и потребление могут приводить (и приводили) к значительному ухудшению природной среды обитания человека.

Для учета не только экономического развития, но одновременно и проводимой государствами экологической политики, разработаны различные подходы. Данные подходы включают два направления: 1) построение отдельных индикаторов

${ }^{2}$ Резолюция, принятая Генеральной ассамблеи ООН 25 сентября 2015 г. // https://undocs.org/ru/A/RES/70/1.

3 Устойчивое развитие: новые вызовы / колл. авторов. - М.: Издательство «Проспект Пресс», 2015 - 336 с., с. 57. 
или/и системы индикаторов, которые показывают различные аспекты устойчивого развития территорий; 2) интегральные показатели эффективности социально-экономического развития, которые включают оценку влияния деятельности человека на окружающую среду.

1) Отдельные индикаторы или/и системы индикаторов устойчивого развития территорий.

1.1) Показатели ресурсоемкости. Данные показатели рассчитываются как удельные затраты на единицу конечного результата (конечной продукции (ТП), ВВП, ВРП): удельная энергоемкость, удельная водоемкость, удельная землеемкость.

1.2) Показатели интенсивности загрязнений. Показатели рассчитываются аналогично предыдущим как удельные величины: удельные величины различных загрязнений, отходов, газов.

Такие показатели необходимо сравнивать в динамике и в сравнении с другими странами, регионами, компаниями.

2) Системы показателей (индикаторы) устойчивого развития.

Индикаторы устойчивого развития разрабатываются различными организациями после конференции ООН в Рио-де-Жанейро в 1992 г. Многие страны включили в свои статистические показатели индикаторы устойчивого развития. Среди наиболее известных систем показателей такие как:

2.1) Индекс человеческого развития (Индекс развития человеческого потенциала);

2.2) Индекс скорректированных чистых накоплений (Всемирный банк);

2.3) Индекс счастья;

2.4) Экологический след (ecological footprint) (WWF);

2.5) Индекс «живой планеты» (living planet index) (WWF);

2.6) Цели устойчивого развития (ЦУР).

Разработанные альтернативные показатели, которые, как считают их приверженцы, лучше показывают реальное состояние развития индивидов, общества и качества жизни в разных странах. Обобщенная характеристика наиболее распространенных систем показателей (индикаторов) представлена в таблице 4. 
Таблииа 4

Характеристика систем показателей устойчивого развития территорий

\begin{tabular}{|c|c|c|}
\hline Показатель & Характеристика & $\begin{array}{c}\text { Единицы } \\
\text { измерения }\end{array}$ \\
\hline $\begin{array}{l}\text { Индекс } \\
\text { «живой } \\
\text { планеты» } \\
\text { (Living Pla- } \\
\text { net index), } \\
\text { ВВФ, 1998 }\end{array}$ & $\begin{array}{l}\text { Содержит } 1100 \text { элементов. } \\
\text { Состоит из набора глобальных индикаторов, } \\
\text { используемых для мониторинга прогресса в } \\
\text { достижении целевых задач по сохранению и } \\
\text { устойчивому использованию биоразнообразия. } \\
\text { Данные, используемые при построении индек- } \\
\text { са, представляют собой временные ряды либо } \\
\text { размера популяции, плотности (численности } \\
\text { популяции на единицу площади), численности } \\
\text { (количество особей на выборку), либо косвен- } \\
\text { ного показателя численности (например, число } \\
\text { зарегистрированных гнезд или гнездящихся пар } \\
\text { может быть использовано вместо этого). Пря- } \\
\text { мого подсчета популяции. Индекс живой плане- } \\
\text { ты в настоящее время основан на данных вре- } \\
\text { менных рядов для } 16704 \text { популяций } 4005 \text { ви- } \\
\text { дов млекопитающих, птиц, рептилий, амфибий } \\
\text { и рыб со всего земного шара. } \\
\text { Основным результатом этого Отчета о живой } \\
\text { планете является то, что в глобальном масштабе } \\
\text { наблюдаемые популяции птиц, млекопитаю- } \\
\text { щих, рыб, рептилий и земноводных сократились } \\
\text { в среднем на } 60 \% \text { в период между } 1970 \text { и } \\
2014 \text { годами. Результаты показывают, что в пре- } \\
\text { сноводных системах виды живут намного хуже. } \\
\text { И в тропических царствах. Пресноводные попу- } \\
\text { ляции сократились в среднем на } 83 \text { \%, в то вре- } \\
\text { мя как области сократились на } 23-89 \%\end{array}$ & $\begin{array}{l}\text { Измеряется } \\
\text { в \%. Рассчи- } \\
\text { тывается } \\
2 \text { раза в год }\end{array}$ \\
\hline $\begin{array}{l}\text { Индекс } \\
\text { скорректи- } \\
\text { рованных } \\
\text { чистых на- } \\
\text { коплений } \\
\text { (Adjusted } \\
\text { net savings), } \\
\text { Всемирный } \\
\text { банк, } 1998\end{array}$ & $\begin{array}{l}\text { Включает восемь групп показателей: } \\
\text { GNS - Gross National Savings - валовые внут- } \\
\text { ренние сбережения); } \\
\text { Dh - Consumption of Fixed Capital - обесце- } \\
\text { нение основного капитала; } \\
\text { Dp - истощение природных peсурсов (Ener- } \\
\text { gy Depletion, Mineral Depletion, Net Forest } \\
\text { Depletion); } \\
\text { CSE - Education Expenditure - текущие pac- } \\
\text { ходы на образование; } \\
\text { CD - CO Damage - ущерб от выбросов CO } \\
\text { PD - PM Damage - ущерб от выбросов твер- } \\
\text { дых взвешенных частиц, диаметром меньше } \\
10 \text { микрон (РМ10) }\end{array}$ & $\begin{array}{l}\text { Измеряется } \\
\text { в \%. Рассчи- } \\
\text { тывается } \\
\text { ежегодно }\end{array}$ \\
\hline
\end{tabular}


Продолжение таблицьь 4

\begin{tabular}{|c|c|c|}
\hline Показатель & Характеристика & $\begin{array}{c}\text { Единицы } \\
\text { измерения }\end{array}$ \\
\hline $\begin{array}{l}\text { «Экологи- } \\
\text { ческий } \\
\text { след» (The } \\
\text { ecological } \\
\text { footprint), } \\
\text { ВВФ, } 1997\end{array}$ & $\begin{array}{l}\text { Рассчитывается как размер территории, не- } \\
\text { обходимой для поглощения всех отходов (на } \\
\text { практике как } \mathrm{CO}_{2} \text { от сжигания природного } \\
\text { топлива) и производства всех ресурсов, по- } \\
\text { требляемых населением страны. } \\
\text { Потребление определяется как разница меж- } \\
\text { ду импортом, внутренним производством и } \\
\text { экспортом. «Россия располагает } 941 \text { млн гга } \\
\text { биоемкости, а ее экологический след состав- } \\
\text { ляет } 569 \text { млн гга, что дает ей примерно } \\
372 \text { млн гга запаса биоемкости (согласно } \\
\text { данным на } 2009 \text { г.). Только Бразилия облада- } \\
\text { ет большим запасом биоемкости, чем Россия. } \\
\text { Однако, в то время как в России биоемкость в } \\
\text { расчете на душу населения растет, в Брази- } \\
\text { лии она неуклонно сокращается» } 4\end{array}$ & $\begin{array}{l}\text { Измеряется } \\
\text { в В. км. } \\
\text { Рассчитыва- } \\
\text { ется ежегод- } \\
\text { но }\end{array}$ \\
\hline $\begin{array}{l}\text { Индекс раз- } \\
\text { вития чело- } \\
\text { веческого } \\
\text { потенциала } \\
\text { (Human de- } \\
\text { velopment } \\
\text { index) }\end{array}$ & $\begin{array}{l}\text { Включает три группы показателей: } \\
\text { - индекс продолжительности жизни; } \\
\text { - индекс образования; } \\
\text { - индекс ВДН на душу населения. }\end{array}$ & $\begin{array}{l}\text { Измеряется } \\
\text { в долях, } \\
\text { ежегодно }\end{array}$ \\
\hline $\begin{array}{l}\text { Индекс } \\
\text { счастья }\end{array}$ & $\begin{array}{l}\text { Включает показатели: } \\
\text { - ВВП на душу населения } \\
\text { - Ожидаемая продолжительность здоровой } \\
\text { жизни; } \\
\text { - Социальная поддержка; } \\
\text { - Свобода жизненного выбора; } \\
\text { - Щедрость; } \\
\text { - Восприятие коррупции }\end{array}$ & $\begin{array}{l}\text { Исследование } \\
\text { проводит Ин- } \\
\text { ститут Земли } \\
\text { при Колум- } \\
\text { бийском уни- } \\
\text { верситете } \\
\text { ((The Earth } \\
\text { Institute) по } \\
\text { решению } \\
\text { OОН в рамках } \\
\text { глобальной } \\
\text { инициативы } \\
\text { «UN Sustaina- } \\
\text { ble Develop- } \\
\text { ment Solutions } \\
\text { Network) }\end{array}$ \\
\hline
\end{tabular}

4 Экологический след субъектов Российской Федерации / общ. ред. П. А. Боев. Всемирный фонд дикой природы (WWF). - M.: WWF России, 2014. - 88 с., с. 21. 
Окончание таблицы 4

\begin{tabular}{|c|c|c|}
\hline Показатель & Характеристика & $\begin{array}{c}\text { Единицы } \\
\text { измерения }\end{array}$ \\
\hline $\begin{array}{l}\text { Цели ус- } \\
\text { тойчивого } \\
\text { развития } \\
\text { ООН }\end{array}$ & $\begin{array}{l}\text { Цели устойчивого развития изложены в Пове- } \\
\text { стке дня в области устойчивого развития на пе- } \\
\text { риод до } 2020 \text { г., они вступили в силу } 01 \text { января } \\
2016 \text { и должны быть достигнуты за } 15 \text { лет. } \\
\text { Включают } 17 \text { целей: } \\
\text { 1. Ликвидация нищеты. } \\
\text { 2. Ликвидация голода. } \\
\text { 3. Хорошее здоровье и благополучие. } \\
\text { 4. Качественное образование. } \\
\text { 5. Гендерное равенство. } \\
\text { 6. Чистая вода и санитария. } \\
\text { 7. Недорогостоящая и чистая энергия. } \\
\text { 8. Достойная работа и экономический рост. } \\
\text { 9. Индустриализация, инновации и инфра- } \\
\text { структура. } \\
\text { 10. Уменьшение неравенства. } \\
\text { 11. Устойчивые города и населённые пункты. } \\
\text { 12. Ответственное потребление и производство. } \\
\text { 13. Борьба с изменением климата. } \\
\text { 14. Сохранение морских животных. } \\
\text { 15. Сохранение экосистем суши. } \\
\text { 16. Мир, правосудие и эффективные институты. } \\
\text { 17. Партнерство в интересах устойчивого } \\
\text { развития }\end{array}$ & $\begin{array}{l}\text { Идет обсуж- } \\
\text { дение и } \\
\text { предложение } \\
\text { по целям ус- } \\
\text { тойчивого } \\
\text { развития для } \\
\text { России. } \\
\text { Росстат пуб- } \\
\text { ликует «Пе- } \\
\text { речень на- } \\
\text { циональных } \\
\text { показателей } \\
\text { устойчивого } \\
\text { развития». } \\
\text { На сайте } \\
\text { Росстата от- } \\
\text { ражена ди- } \\
\text { намика раз- } \\
\text { работки ме- } \\
\text { тодологии и } \\
\text { приведен } \\
\text { расчет пока- } \\
\text { зателей }\end{array}$ \\
\hline
\end{tabular}

Примечание. Источники: Living Planet Report 2018 Technical Supplement: Living Planet Index; Экологический след субъектов Российской Федерации / общ. Ред. П. А. Боев. - Всемирный фонд дикой природы (WWF). - M.: WWF России, 2014. - 88 с.; Варавин Е. В., Козлова М. В. Оценка развития зеленой экономики в регионе. На примере Республики Казахстан // Экономика региона. - 2018. Т. 14, вып. 4. - С. 1282-1297, с. 1284; Эколого-экономический индекс регионов РФ. Методика и показатели для расчета / С. Н. Бобылев, В. С. Минаков и др. M.: WWF России, РИА Новости, 2012. - 152 с. // https://wwf.ru/upload/iblock/ dc8/index.pdf, с. 18; Сайт ООН // https://www.un.org/sustainabledevelopment/ru/ about/development-agenda/; Преобразование нашего мира: Повестка дня в области устойчивого развития на период до 2030 года. Резолюция, принятая Генеральной Ассамблеей 25 сентября 2015 года // https://undocs.org/ru/A/RES/70/1; Сайт Росстата // http://www.gks.ru/wps/wcm/connect/rosstat_main/rosstat/ru/ statistics/goalOfDevelopment; John F. Helliwell, Richard Layard and Jeffrey D. Sachs. World Happiness Report 2019, New York: Sustainable Development Solutions Network. 
Рассмотрим наиболее известные системы показателей /индикаторов, характеризующих различные аспекты экологического, социального, экономического развития территорий.

1. Индекс человеческого развития. Показатели, входящие в расчет Индекса человеческого развития ${ }^{5}$ :

1. Ожидаемая продолжительность жизни при рождении: количество лет, которое может прожить новорожденный младенец, если существующие на момент его рождения преобладающие тенденции в области показателей смертности для конкретных возрастных групп останутся без изменений на протяжении всей его жизни.

2. Ожидаемая продолжительность обучения: количество лет образования, которое, как ожидается, может получить ребенок, достигший официально установленного возраста поступления в школу, если в течение его жизни сохранятся преобладающие тенденции в области возрастных показателей охвата населения образованием.

3. Средняя продолжительность обучения: среднее количество лет образования, полученного лицами в возрасте 25 лет и старше, пересчитанное из показателя образовательного уровня населения с учетом официальной продолжительности каждого уровня образования.

\section{4. Валовой национальный доход (ВНД) на душу населе-} ния: совокупный доход экономики, полученный в ходе производства и владения факторами производства, минус плата за пользование факторами производства, принадлежащими остальному миру, конвертированный в международные доллары с использованием коэффициентов паритета покупательной способности (ППС) и разделенный на численность населения по состоянию на середину года.

ИРЧП представляет собой среднее геометрическое трех индексов измерений (формула 1 , рис. 3):

${ }^{5}$ The World Only.От понимания к устойчивому развитию. News of the age of sustainable development // https://thew orldonly.org/indeks-chelovecheskogorazvitiya-po-stranam/, Индексы и индикаторы человеческого развития: Обновленные статистические данные 2018. Программа развития Организации Объединенных Наций (ПРООН), 2018. - 122 с. 


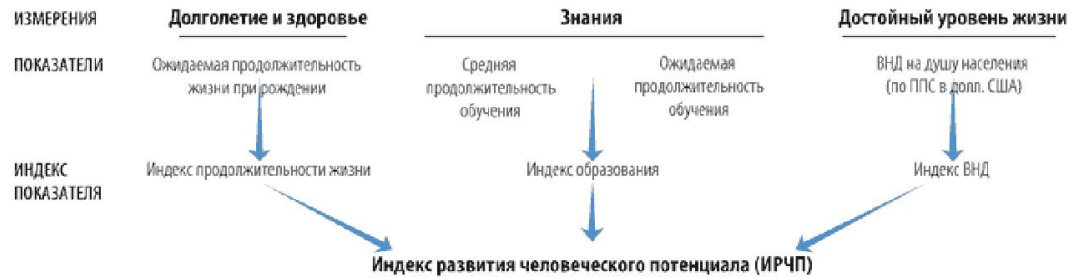

Рис. 3. Индекс развития человеческого потенциала

Примечание. Источник: https://theworldonly.org/indeks-chelovecheskogorazvitiya-po-stranam/\#табл.

$$
\text { HDI }=(\text { Іжизнь * Іобразование * Ідоход })^{1 / 3} \text {, }
$$

где I = (фактическое значение - минимальное значение) / (максимальное значение - минимальное значение).

Страны делятся на три группы: страны с высоким уровнем человеческого развития, страны со средним уровнем человеческого развития, страны с низким уровнем человеческого развития. Россия, согласно данным рейтинга, относится к странам с высоким уровнем человеческого развития и занимала в 2017 г. 49 место из 58 стран, входящих в данную группу. Значения индекса человеческого развития по первым трем странам-лидерам рейтинга и данные по России за 2016 и 2017 гг. приведены в таблице 5.

Таблиия 5

Индекс человеческого развития и его компоненты (фрагмент)

\begin{tabular}{|c|c|c|c|c|c|c|c|}
\hline Страны & $\begin{array}{c}\text { Индекс } \\
\text { че- } \\
\text { ловече- } \\
\text { ского } \\
\text { разви- } \\
\text { тия } \\
\text { (ИЧР) }\end{array}$ & \begin{tabular}{|c|} 
Ожидае- \\
мая про- \\
должи- \\
тельность \\
жизни \\
при рож- \\
дении \\
(ЦУР 3) \\
\end{tabular} & $\begin{array}{c}\text { Ожидае- } \\
\text { мая про- } \\
\text { должи- } \\
\text { тельность } \\
\text { обучения } \\
\text { (ЦУР 3,4) }\end{array}$ & \begin{tabular}{|c} 
Средняя \\
продол- \\
жи- \\
тельность \\
обучения \\
(ЦУР 4,6)
\end{tabular} & $\begin{array}{c}\text { Валовой } \\
\text { нацио- } \\
\text { нальный } \\
\text { доход } \\
\text { (ВДН) на } \\
\text { душу на- } \\
\text { селения } \\
\text { (ЦУР 8,5) }\end{array}$ & \begin{tabular}{|c} 
Рейтинг \\
по ВНД \\
на душу \\
населе- \\
ния \\
минус \\
рейтинг \\
по ИЧР \\
\end{tabular} & $\begin{array}{c}\text { Рей- } \\
\text { тинг } \\
\text { по ИЧР }\end{array}$ \\
\hline & $\begin{array}{l}\text { 3на- } \\
\text { чение }\end{array}$ & в годах & в годах & в годах & $\begin{array}{c}\text { в долл. } \\
\text { США } \\
2011 \\
\text { по ППС }\end{array}$ & & \\
\hline & 2017 & 2017 & 2017 & 2017 & 2017 & 2017 & 2016 \\
\hline \multicolumn{8}{|c|}{ Страны с очень высоким уровнем человеческого развития } \\
\hline 1. $\mathrm{H}$ & 0,953 & 82,3 & 17,9 & 12,6 & 68012 & 5 & 1 \\
\hline 2. Швейцария & 0,944 & 83,5 & 16,2 & 13,4 & 57625 & 8 & 2 \\
\hline
\end{tabular}


Окончание таблицьь 5

\begin{tabular}{|c|c|c|c|c|c|c|c|}
\hline Страны & \begin{tabular}{|c|} 
Индекс \\
че- \\
ловече- \\
ского \\
разви- \\
тия \\
(ИЧР)
\end{tabular} & \begin{tabular}{|c|} 
Ожидае- \\
мая про- \\
должи- \\
тельность \\
жизни \\
при рож- \\
дении \\
(ЦУР 3) \\
\end{tabular} & $\begin{array}{c}\text { Ожидае- } \\
\text { мая про- } \\
\text { должи- } \\
\text { тельность } \\
\text { обучения } \\
\text { (ЦУР } 3,4)\end{array}$ & $\begin{array}{c}\text { Средняя } \\
\text { продол- } \\
\text { жи- } \\
\text { тельность } \\
\text { обучения } \\
\text { (ЦУР 4,6) }\end{array}$ & $\begin{array}{c}\text { Валовой } \\
\text { нацио- } \\
\text { нальный } \\
\text { доход } \\
\text { (ВДН) на } \\
\text { душу на- } \\
\text { селения } \\
\text { (ЦУР 8,5) }\end{array}$ & \begin{tabular}{|c} 
Рейтинг \\
по ВНД \\
на душу \\
населе- \\
ния \\
минус \\
рейтинг \\
по ИЧР \\
\end{tabular} & $\begin{array}{c}\text { Рей- } \\
\text { тинг } \\
\text { по ИЧР }\end{array}$ \\
\hline & $\begin{array}{c}\text { зна- } \\
\text { чение }\end{array}$ & в годах & в годах & в годах & $\begin{array}{c}\text { в долл. } \\
\text { США } \\
2011 \\
\text { по ППС }\end{array}$ & & \\
\hline & 2017 & 2017 & 2017 & 2017 & 2017 & 2017 & 2016 \\
\hline \multicolumn{8}{|c|}{ Страны с очень высоким уровнем человеческого развития } \\
\hline 3. Австралия & 0,939 & 83,1 & $22,9^{1}$ & 12,9 & 43560 & 18 & 3 \\
\hline $\begin{array}{l}\text { 49. Российская } \\
\text { Федерация }\end{array}$ & 0,816 & 71,2 & 15,5 & $12,0^{2}$ & 24233 & 3 & 49 \\
\hline
\end{tabular}

Примечания. ЦУР - цели устойчивого развития; ${ }^{1}$ - для целей расчета ИЧР установлено предельное значение ожидаемой продолжительности обучения - 18 лет; ${ }^{2}$ - Обновлено ОДЧР на основе данных UNESCO Institute for Statistics (2018).

Источник: Доклад: Индексы и индикаторы человеческого развития. Обновленные статистические данные 2018 //Опубликовано для Программы развития Организации Объединенных Наций (ПРООН). 122 c., c.39 // http:// hdr.undp.org/en/2018-update/download, hdr.undp.org/en/2018-update.

Таблицุа 6

\section{Экологическая устойчивость (фрагмент)}

\begin{tabular}{|c|c|c|c|c|}
\hline \multirow[t]{3}{*}{ Страна } & $\begin{array}{l}\text { Потребление } \\
\text { энергии, про- }\end{array}$ & $\begin{array}{c}\text { Потребление во- } \\
\text { зобновляемых ис- }\end{array}$ & \multicolumn{2}{|c|}{$\begin{array}{c}\text { Выбросы диоксида } \\
\text { углерода }\end{array}$} \\
\hline & $\begin{array}{c}\text { (\% совокупного } \\
\text { объема энерго- } \\
\text { потребления) } \\
\end{array}$ & $\begin{array}{c}\text { (\% совокупного } \\
\text { объема конечного } \\
\text { энергопотребления) }\end{array}$ & $\begin{array}{c}\text { На душу } \\
\text { населения } \\
\text { (тонн) } \\
\end{array}$ & $\begin{array}{c}\text { кг на } \\
1 \text { долл. } \\
\text { ВВП }^{3} \\
\end{array}$ \\
\hline & $2010-2015^{1}$ & 2015 & 2014 & 2014 \\
\hline 1. Норвегия & 58,5 & 57,8 & 9,3 & 0,15 \\
\hline 2. Швейцария & 50,1 & 25,3 & 4,3 & 0,08 \\
\hline 3. Австралия & 93,4 & 9,2 & 15,4 & 0,35 \\
\hline 4. Ирландия & 85,4 & 9,1 & 7,3 & 0,15 \\
\hline 5. Германия & 79,8 & 14,2 & 8,9 & 0,20 \\
\hline $\begin{array}{l}\text { 49. Российская } \\
\text { Федерация }\end{array}$ & 90,2 & 3,3 & 11,9 & 0,46 \\
\hline
\end{tabular}


Окончание таблицы 6

\begin{tabular}{|l|c|c|c|c|c|c|}
\hline \multicolumn{1}{|c|}{ Страна } & \multicolumn{2}{|c|}{ Площадь лесов } & $\begin{array}{c}\text { Потребление } \\
\text { пресной воды }\end{array}$ & $\begin{array}{c}\text { Экологические угро- } \\
\text { зы: смертность, } \\
\text { предположительно } \\
\text { связанная с }\end{array}$ \\
\cline { 2 - 7 } & $\begin{array}{c}\text { (\% общей } \\
\text { площади } \\
\text { земель) }\end{array}$ & $\begin{array}{c}\text { Измене- } \\
\text { ние (\%) }\end{array}$ & $\begin{array}{c}\text { (\% общего объ- } \\
\text { ема возоб- } \\
\text { новляемых вод- } \\
\text { ных ресурсов) }\end{array}$ & 4 & 5 & 6 \\
\cline { 2 - 7 } & $\mathbf{2 0 1 5}$ & $\mathbf{1 9 9 0 / 2 0 1 5}$ & $\mathbf{2 0 0 6 - 2 0 1 6} \mathbf{2}^{2}$ & $\mathbf{2 0 1 6}$ & $\mathbf{2 0 1 6}$ & $\mathbf{2 0 1 7}$ \\
\hline 1. Норвегия & 33,2 & $-0,2$ & 0,8 & 8,6 & 0,2 & 0,943 \\
\hline 2. Швейцария & 31,7 & 9,0 & 3,7 & 10,1 & 0,1 & 0,982 \\
\hline 3. Австралия & 16,2 & $-2,9$ & 3,4 & 8,4 & $0,1{ }^{2}$ & 0,828 \\
\hline 4. Ирландия & 10,9 & 62,2 & 1,5 & 11,9 & $0,1{ }^{2}$ & 0,917 \\
\hline 5. Германия & 32,7 & 1,1 & 21,4 & 16,0 & 0,6 & 0,983 \\
\hline $\begin{array}{l}\text { 49. Российская } \\
\text { Федерация }\end{array}$ & 49,8 & 0,8 & 1,3 & 49,4 & 0,1 & 0,956 \\
\hline
\end{tabular}

Примечания. ЦУР - цели устойчивого развития; ${ }^{1}$ - данные относятся к последнему году указанного периода, за который имеется статистика; ${ }^{2}-$ относится к 2011 г.; ${ }^{3}$ - кг на 1 долл. ВВП, измеряемого в долл. США 2011 г. по ППС; 4 - Загрязнением воздуха внутри помещений и атмосферного воздуха; ${ }^{5}-$ Небезопасной водой, отсутствием доступа к санитарно-гигиеническим услугам; ${ }^{6}{ }_{-}$ Индекс Красной книги.

\section{Определения:}

Потребление энергии, производимой из ископаемого топлива: процентная доля ископаемого топлива (включая продукты переработки каменного угля, нефти и природного газа) в совокупном объеме энергопотребления.

Потребление возобновляемых источников энергии: доля возобновляемых энергоресурсов в совокупном объеме конечного энергопотребления. Возобновляемые энергоресурсы включают в себя гидроэнергетические и геотермальные ресурсы, энергию солнца, приливов, ветра, биомассы и биотоплива.

Выбросы диоксида углерода: антропогенные выбросы диоксида углерода, происходящие в результате сгорания ископаемого топлива, сжигания газа и производства цемента. Включает в себя диоксид углерода, выделяемый биомассой леса при истощении лесов.

Статистические данные выражены в тоннах на душу населения (по состоянию на середину года) и в килограммах на единицу валового внутреннего продукта (ВВП), измеряемого в долларах США 2011 г. по паритету покупательной способности (ППС).

Площадь лесов: участки суши, простирающиеся более чем на 0,5 га, с деревьями высотой более 5 м и растительным покровом, занимающим более $10 \%$ этой площади, или деревьями, способными достигать этих пороговых значе- 
ний в естественных условиях. Данный показатель не включает в себя территории, находящиеся преимущественно в сельскохозяйственном или городском землепользовании, древонасаждения в системах сельскохозяйственного производства (например, на фруктовых плантациях или в системах агромелиорации) и деревья в городских парках и садах. В показатель включены территории, отданные под лесовозобновление, которые еще не достигли, но, как ожидается, должны достигнуть 10\%-ного уровня растительного покрова и высоты деревьев в 5 м, а также территории, временно обезлесенные в результате естественных причин или вмешательства человека, на которых, как ожидается, будет проведено лесовосстановление.

Потребление пресной воды: совокупный отбор пресной воды, в процентах к общему объему возобновляемых водных ресурсов.

Смертность, предположительно связанная с загрязнением воздуха внутри помещений и атмосферного воздуха: количество случаев смерти от воздействия загрязнения окружающего (атмосферного) воздуха, а также воздуха внутри помещений в результате использования твердого топлива для приготовления пищи, выраженное в пересчете на 100 тыс. человек населения. Источниками загрязнения атмосферного воздуха являются промышленные выбросы, а также выбросы, производимые домохозяйствами, легковыми и грузовыми автомобилями.

Смертность, предположительно связанная с небезопасной водой, отсутствием доступа к санитарно-гигиеническим услугам: число случаев смерти, предположительно связанных с небезопасными водой, канализацией и гигиеной и, в первую очередь, с неудовлетворительными санитарно-гигиеническими условиями, выраженное в пересчете на 100 тыс. чел. Населения.

Индекс Красной книги: показатель совокупного риска исчезновения по группам биологических видов. Основан на реальных изменениях числа видов животных и растений по каждой категории риска исчезновения согласно классификации степени угроз, приведенной в Красной книге Международного союза охраны природы и природных ресурсов (МСОП). Степень угроз варьируется от 0 (исчезнувшие) до 1 (находятся под наименьшей угрозой).

Источник: Доклад: Индексы и индикаторы человеческого развития. Обновленные статистические данные 2018 // Опубликовано для Программы развития Организации Объединенных Наций (ПРООН). 122 с., с. 105-109. // http:// hdr.undp.org/en/2018-update/download, hdr.undp.org/en/2018-update.

В Докладе отражены данные и по экологической устойчивости стран (см. табл. 6). Экологическая устойчивость оценивается по таким показателям как: потребление энергии, производимой из ископаемого топлива (\% совокупного объема энергопотребления), потребление возобновляемых источников энергии, выбросы диоксида углерода (на душу населения (тонн)), площадь лесов (\% общей площади земель), потребление пресной воды (\% общего объе- 
ма возобновляемых водных ресурсов, экологические угрозы (смертность, выраженная в пересчете на 100 тыс. человек населения).

2. Индекс счастья. Показатели, входящие в расчет для вычисления индекса счастья ${ }^{6}$ :

1. ВВП на душу населения (GDP per capita) с учетом внутренних цен (ППС) в USD 2011 года. Уравнение использует натуральный логарифм ВВП на душу населения, так как эта форма соответствует данным значительно лучше, чем ВВП на душу населения.

2. Ожидаемая продолжительность здоровой жизни (healthy life expectancy).

3. Социальная поддержка (social support) - средний национальный ответ на вопрос (0 или 1) Gallup World Poll (GWP) «Если бы у вас была проблема, могли бы вы рассчитывать на помощь родственников или друзей в случае необходимости?» (If you were in trouble, do you have relatives or friends you can count on to help you whenever you need them, or not?").

4. Свобода жизненного выбора (freedom to make life choices). Средний национальный ответ на вопрос (0 или 1) Gallup World Poll (GWP): «Вы удовлетворены или не удовлетворены свободой выбора того, что вы делаете со своей жизнью?» (Are you satisfied or dissatisfied with your freedom to choose what you do with your life?).

5. Щедрость (generosity): «Тратили ли вы на благотворительность деньги в прошлом месяце?» (Generosity is the residual of regressing national average of response to the GWP question «Have you donated money to a charity in the past month?» on GDP per capita.).

6. Восприятие коррупции (perceptions of corruption) - средний национальный ответ на вопрос (0 или 1) Gallup World Poll (GWP): «Распространена ли коррупция в правительстве или нет?» («Is corruption widespread throughout the government or not?») и «Pacпространена ли коррупция в бизнесе или нет?» («Is corruption widespread within businesses or not?»). Там, где отсутствуют дан-

${ }^{6}$ The World Only.От понимания к устойчивому развитию. News of the age of sustainable development // https://theworldonly.org/indeks-schastya-2019/; Statistical Appendix 1 for Chapter 2 of World Happiness Report 2019, by John F. Helliwell, Haifang Huang and Shun Wang. March 7, 2019; https://worldhappiness.report/. 
ные о коррупции в правительстве, в качестве общей меры восприятия коррупции используется восприятие коррупции в бизнесе. Кроме того, на результат влияло субъективное ощущение счастья или несчастья. Например, учитывались ответы на вопросы о прошедшем дне: смеялись? Было ли ощущение счастья? Испытывали беспокойство? Гнев? (Positive Affect и Negative Affect). Каждая страна также сравнивается с гипотетической страной под названием «Антиутопия». Антиутопия представляет самые низкие национальные средние значения для каждой ключевой переменной.

Данные показатели напрямую не учитывают экологические критерии, кроме того, индекс счастья включает субъективные оценочные показатели индивидуумов и экспертные мнения.

В таблице 7 представлен фрагмент рейтинга стран мира по показателю «счастье населения». Исследование проводит Институт Земли при Колумбийском университете ((The Earth Institute $\left.{ }^{7}\right)$ по решению ООН в рамках глобальной инициативы «UN Sustainable Development Solutions Network) ${ }^{8}$.

Таблицуа 7

Рейтинг стран мира по уровню счастья населения в 2017 году (World Нappiness Report 2017) (фрагмент)

\begin{tabular}{|c|l|c|}
\hline № п/п & \multicolumn{1}{|c|}{ Страна } & Индекс счастья \\
\hline 1 & Норвегия & 7.537 \\
\hline 2 & Дания & 7.522 \\
\hline 3 & Исландия & 7.504 \\
\hline 4 & Швейцария & 7.494 \\
\hline 5 & Финляндия & 7.469 \\
\hline $\mathbf{4 9}$ & Россия & $\mathbf{5 . 9 6 3}$ \\
\hline 155 & Центрально-Африканская Республика & 2.693 \\
\hline
\end{tabular}

Примечание. Источник: Аналитический портал «Гуманитарные технологии» // https://gtmarket.ru/news/2017/03/20/7316

${ }^{7}$ Официальный сайт The Earth Institute: https://www.earth.columbia.edu/.

8 «The UN Sustainable Development Solutions Network (SDSN) has been operating since 2012 under the auspices of the UN Secretary-General. SDSN mobilizes global scientific and technological expertise to promote practical solutions for sustainable development, including the implementation of the Sustainable Development Goals (SDGs) and the Paris Climate Agreement» // Официальный сайт SDSN :http://unsdsn.org/. 
Цель исследования - выявить факторы, способствующие счастью несчастью населения разных стран. Авторы исследования считают, что это поможет правительствам лучше понять своих граждан и свою роль в повышении удовлетворенности жизнью населения. Первый доклад вышел в 2012 г. В 2017 г. самими счастливыми являлись жители Норвегии, Дании, Исландии. США оказались на 14 строчке, Германия - на 16, Великобритания - на 19, Бразилия - на 22, Франция - на 31, Италия - на 48, Япония - на 51, Китай - на 79, Индия - на 122. Россия заняла 49 место из 155.

3. Индекс скорректированных чистых накоплений (Всемирный банк).

По оценке специалистов (Бобылев С.Н.) ${ }^{9}$ индекс скорректированных чистых накоплений (adjusted net saving) является одним из наиболее адекватных показателей, характеризующих устойчивость развития и экологическую нагрузку страны. При расчете данного показателя традиционных показатель валовых инвестиций (GNS - Gross National Savings валовые внутренние сбережения) корректируется на таких показатели как: Dh - Consumption of Fixed Capital - обесценение основного капитала;

$\mathrm{Dp}$ - истощение природных ресурсов (Energy Depletion, Mineral Depletion, Net Forest Depletion),

CSE - Education Expenditure - текущие расходы на образование,

$\mathrm{CD}$ - $\mathrm{CO}_{2}$ Damage - ущерб от выбросов $\mathrm{CO}_{2}$,

PD - PM Damage - ущерб от выбросов твердых взвешенных частиц, диаметром меньше 10 микрон (РМ10).

${ }^{9}$ Устойчивое развитие : Новые вызовы : Учебник для вузов / Под общ. ред. В.И. Данилова-Данильяна, Н.А. Пискуловой. - М.: Изд-во «Аспект Пресс», 2015. - 336 с., п. 3.3. Интегральные индикаторы устойчивого развития, с. 63.

10 Эколого-экономический индекс регионов РФ. Методика и показатели для расчета / С. Н. Бобылев, В. С. Минаков и др. - М. : WWF России, РИА Новости, 2012. - 152 с. // https://wwf.ru/upload/iblock/dc8/index.pdf, c. 22. 
Формула расчета скорректированных чистых накоплений (ANS) имеет следующий вид ${ }^{10}$ (формула 2):

$$
\text { ANS }=\text { GNS }- \text { Dh }+ \text { CSE }- \text { Dp }- \text { CD }- \text { PD }
$$

«Истощение невозобновляемых природных ресурсов (Dp) определяется как отношение приведенной стоимости ренты, дисконтированной по процентной ставке $r$, к периоду исчерпания природного ресурса. Это истощение оценивается следующим образом. Для каждого вида невозобновляемых ресурсов природная рента $\mathrm{R}$ рассчитывается по странам мира как (формула 3 ):

$$
\mathbf{R}=(\mathbf{P}-\mathbf{C}) \cdot \mathbf{Q}
$$

где $\mathrm{P}$ - цена природного ресурса на мировом рынке, $\mathrm{C}$ - средние затраты на добычу ресурса в стране, Q - объем добычи природного ресурса.

Тогда:

$$
\mathbf{D p}=\left(\sum \mathbf{R}(\mathbf{1}+\mathbf{r})-1\right) / \mathbf{T}
$$

где $\mathrm{r}$ - процентная ставка, равна 4 \%, Т - период исчерпания природного ресурса. Определяется как отношение запасов (нефти, газа, угля и др.) к годовой добыче, не менее 25 лет» ${ }^{11}$.

Фрагмент Adjusted Net Saving по различным странам, имеющими наиболее высокое и наименее низкие значения показателя приведены в таблицах 8, 9. Расчеты ANS показывают: Россия имеет положительное значение ANS, но показатель на душу населения (per capita) - отрицательная величина, что является негативной оценкой. Значение Education Expenditure значительно меньше, чем у развитых стран, а показатель истощения ресурсов (Energy Depletion) очень значителен. Положителен пример Норвегии, которая показывает высокое значение ANS при значительном потреблении основного капитала (Consumption of Fixed Capital). США имеет

11 Эколого-экономический индекс регионов РФ. Методика и показатели для расчета / С. Н. Бобылев, В. С. Минаков и др. - М. : WWF России, РИА Новости, 2012. - 152 с. // https://wwf.ru/upload/iblock/dc8/index.pdf, c. 22. 
низкое значение ANS, но на душу населения показатель (Adjusted Net Saving Per Capita) является одним из самых высоких.

Таблиияа 8

\section{Calculating Adjusted Net Saving as a Percentage of Gross National Income, 2008 (фрагмент)}

\begin{tabular}{|l|c|c|c|c|c|c|c|c|}
\hline $\begin{array}{c}\text { Economy / } \\
\text { Group }\end{array}$ & $\begin{array}{c}\text { Aus- } \\
\text { tralia }\end{array}$ & $\begin{array}{c}\text { Cana- } \\
\text { da }\end{array}$ & $\begin{array}{c}\text { Nor- } \\
\text { way }\end{array}$ & $\begin{array}{c}\text { Rus- } \\
\text { sian } \\
\text { Feder- } \\
\text { ation }\end{array}$ & $\begin{array}{c}\text { United } \\
\text { King- } \\
\text { dom }\end{array}$ & $\begin{array}{c}\text { United } \\
\text { States }\end{array}$ & $\begin{array}{c}\text { Uzbe- } \\
\text { kistan }\end{array}$ & $\begin{array}{c}\text { Venezu- } \\
\text { ela, RB }\end{array}$ \\
\hline $\begin{array}{l}\text { Gross Na- } \\
\text { tional Sav- } \\
\text { ings }\end{array}$ & 32.9 & 23.4 & 41.2 & 32.8 & 14.8 & 12.6 & 40.5 & 34.6 \\
\hline $\begin{array}{l}\text { Consump- } \\
\text { tion of Fixed } \\
\text { Capital }\end{array}$ & 14.7 & 14.0 & 15.0 & 12.4 & 13.7 & 14.0 & 8.5 & 11.9 \\
\hline $\begin{array}{l}\text { Net Nation- } \\
\text { al Savings }\end{array}$ & 18.1 & 9.4 & 26.2 & 20.4 & 1.2 & -1.4 & 32.0 & 22.7 \\
\hline $\begin{array}{l}\text { Education } \\
\text { Expenditure }\end{array}$ & 5.1 & 4.8 & 6.0 & 3.5 & 5.1 & 4.8 & 9.4 & 3.5 \\
\hline $\begin{array}{l}\text { Energy } \\
\text { Depletion }\end{array}$ & 4.1 & 5.5 & $15.9 .$. & 20.5 & 2.1 & 1.9 & 51.1 & 18.6 \\
\hline $\begin{array}{l}\text { Mineral } \\
\text { Depletion }\end{array}$ & 3.8 & 0.6 & $\ldots$ & 1.0 & 0 & 0.1 & 0 & 0.6 \\
\hline $\begin{array}{l}\text { Net Forest } \\
\text { Depletion }\end{array}$ & 0 & 0 & 0 & 0 & 0 & 0 & 0 & 0 \\
\hline $\begin{array}{l}\text { CO Dam- } \\
\text { age De }\end{array}$ & 0.3 & 0.3 & 0.1 & 0.9 & 0.2 & 0.3 & 4.0 & 0.5 \\
\hline $\begin{array}{l}\text { PM Dam- } \\
\text { age }\end{array}$ & $\ldots$ & 0.1 & $\ldots$ & 0.1 & $\ldots$ & 0.1 & 0.4 & 0 \\
\hline $\begin{array}{l}\text { Adjusted } \\
\text { Net Savings }\end{array}$ & $\mathbf{1 5}$ & $\mathbf{7 . 6}$ & $\mathbf{1 6 . 2}$ & $\mathbf{1 . 5}$ & $\mathbf{3 . 9}$ & $\mathbf{0 . 9}$ & $\mathbf{- 1 4 , 1}$ & $\mathbf{6 . 5}$ \\
\hline
\end{tabular}

Примечание. The following table shows the national accounting flows used to estimate adjusted net saving by economy for the year 2008. Adjusted net saving is equal to gross savings minus consumption of fixed capital, plus education expenditure, minus energy depletion, mineral depletion, net forest depletion, carbon dioxide damages, and particulate matter (PM)damages. Estimates are expressed as a percentage of GNI. Refer to World Development Indicators 2010 for the calculation of adjusted net saving by geographic region and income category. Источник: The Changing Wealth of Nations. Measuring Sustainable Development in the New Millennium. 2011, The International Bank for Reconstruction and Development / The World Bank // ISBN 978-0-8213-8488-6 - ISBN 978-0-8213-8554-8 (electronic). C. 185-194. 
Таблица 9

\section{Effect of Population Growth on Savings and Changes in Wealth Per Capita, 2005}

\begin{tabular}{|l|c|c|c|c|c|}
\hline Economy & $\begin{array}{c}\text { GNI } \\
\text { Per } \\
\text { Capita } \\
\text { (US\$) }\end{array}$ & $\begin{array}{c}\text { Population } \\
\text { Growth } \\
\text { Rate (\%) }\end{array}$ & $\begin{array}{c}\text { Adjusted } \\
\text { Net Saving } \\
\text { Per Capita } \\
\text { (US\$) }\end{array}$ & $\begin{array}{c}\text { Change in } \\
\text { Wealth } \\
\text { Per Capita } \\
\text { (US\$) }\end{array}$ & $\begin{array}{c}\text { Adjusted } \\
\text { Net Saving } \\
\text { Gap } \\
\text { (\% GNI) }\end{array}$ \\
\hline Australia & 31,962 & 1.2 & 2,217 & 655 & n.a. \\
\hline Canada & 34,505 & 1.0 & 2,081 & 881 & n.a. \\
\hline Norway & 65,776 & 0.7 & 5,504 & 3,254 & n.a. \\
\hline Russian Federation & 5,209 & -0.5 & -13 & 236 & n.a. \\
\hline United Kingdom & 38,048 & 0.7 & 1,162 & 613 & n.a. \\
\hline United States & 41,966 & 0.9 & 182 & -821 & 2.0 \\
\hline Uzbekistan & 546 & 1.2 & -168 & -276 & 50.5 \\
\hline Venezuela, RB & 5,390 & 1.7 & 208 & -613 & 11.4 \\
\hline
\end{tabular}

Примечание. The table shows how population growth affects measures of savings and changes in wealth per capita. The first column shows GNI per capita. This is used just for reference. The second column shows the rate of population growth. The third and fourth columns show two alternative measures of capital accumulation that take into account population: adjusted net saving per capita and change in wealth per capita. The difference between the two columns is driven by the "Malthusian term". The fifth column shows how much extra savings (as a percentage of GNI) would be needed to obtain a zero change in wealth per capita. Data are for 2005. Источник. The Changing Wealth of Nations. Measuring Sustainable Development in the New Millennium. 2011, The International Bank for Reconstruction and Development / The World Bank // ISBN 978-0-8213-8488-6 - ISBN 978-0-8213-8554-8 (electronic). C. 197-194.

ASN имеет ряд недостатков ${ }^{12}$ : он не учитывает ряд положительных и отрицательных экстерналий, но дает интегрированную оценку устойчивого развития стран. Исследователи отмечают, что показатель скорректированных чистых накоплений демонстрирует «необходимость компенсации истощения природного капитала и ущерба от загрязнения окружающей среды за счет роста инвестиций в человеческий и физический капиталы». Как недостаток можно указать, что в «теоретическом плане речь идет о слабой устойчивости и о взаимозаменяемости различных видов капиталов»13.

12 Устойчивое развитие: Новые вызовы: Учебник для вузов / Под общ. ред. В.И. Данилова-Данильяна, Н.А. Пискуловой. - М.: Изд-во «Аспект Пресс», 2015. - 336 с., п. 3.3. Интегральные индикаторы устойчивого развития, с. 65.

13 Эколого-экономический индекс регионов РФ. Методика и показатели для расчета / С. Н. Бобылев, В. С. Минаков и др. - М. : WWF России, РИА Новости, 2012. - 152 с. // https://wwf.ru/upload/iblock/dc8/index.pdf, c. 31. 
В российской практике наибольшее использование получил именно показатель скорректированных чистых накоплений (ANS). Так, российские ученые С.Н. Бобылев, В. С. Минаков, предложили скорректированную формулу расчета показателя ANS и на его основе рассчитали эколого-экономический индекс для российских регионов в 2012 г. $^{14}$. Формулы имеют следующий вид $(5,6)$ :

$$
\text { СЧН }=\text { ВН }- \text { ИД }- \text { ИПР }- \text { УЗОС }+ \text { РЧК }+30 \mathrm{C}+\text { ООПТ, }
$$

где СЧН - скорректированные чистые накопления; ВН - валовые накопления основного капитала; ИД - инвестиции в основной капитал по виду деятельности «Добыча полезных ископаемых»; ИПР - истощение природных ресурсов; УЗОС - ущерб от загрязнения окружающей среды; РЧК - расходы бюджета на развитие человеческого капитала; 3ОС - затраты на охрану окружающей среды; ООПТ - оценка особо охраняемых природных территорий.

Эколого-экономический индекс (Индекс скорректированных чистых накоплений - ИСЧН) рассчитывался как отношение скорректированных чистых накоплений к ВРП (формула 6).

$$
\text { ИСЧН }=\text { СЧН } / \text { ВРП } \times 100 \%,
$$

где СЧН - скорректированные чистые накопления; ВРП - валовой региональный продукт.

Все регионы были разделены исследователями на четыре группы (таблица 10) ${ }^{15}$ :

1) Финансово-экономические центры;

2) Экспортно-ориентированные регионы;

3) Промышленные регионы;

4) Аграрно-промышленные регионы.

14 Эколого-экономический индекс регионов РФ. Методика и показатели для расчета / С. Н. Бобылев, В. С. Минаков и др. - М. : WWF России, РИА Новости, 2012. - 152 с. // https://wwf.ru/upload/iblock/dc8/index.pdf.

15 Деление производилось на основе принципов, изложенных в: Российские регионы: экономический кризис и проблемы модернизации / Под ред. Л.М. Григорьева, Н.В. Зубаревич, Г.Р. Хасаева. - М.: ТЕИС, 2011. 
Таблица 10

\section{Классификация российских регионов}

\begin{tabular}{|l|l|}
\hline \multicolumn{1}{|c|}{ Группа } & \multicolumn{1}{|c|}{ Состав группы } \\
\hline $\begin{array}{l}\text { Финансово- } \\
\text { экономические } \\
\text { центры }\end{array}$ & Москва, г. Санкт-Петербург, Московская область \\
\hline $\begin{array}{l}\text { Экспортно- } \\
\text { ориентированные } \\
\text { регионы }\end{array}$ & $\begin{array}{l}\text { Ненецкий автономный округ, Республика Коми, Рес- } \\
\text { публика Саха (Якутия), Сахалинская область, Тюмен- } \\
\text { ская область, Ханты-Мансийский автономный округ- } \\
\text { Югра, Ямало-Ненецкий автономный округ }\end{array}$ \\
\hline $\begin{array}{l}\text { Промышленные } \\
\text { регионы }\end{array}$ & $\begin{array}{l}\text { Архангельская область, Белгородская область, Владимир- } \\
\text { ская область, Вологодская область, Ивановская область, } \\
\text { Иркутская область, Калининградская область, Калужская } \\
\text { область, Кемеровская область, Костромская область, } \\
\text { Красноярский край, Ленинградская область, Липецкая } \\
\text { область, Мурманская область, Нижегородская область, } \\
\text { Новгородская область, Новосибирская область, Омская } \\
\text { область, Пермский край, Приморский край, Республика } \\
\text { Башкортостан, Республика Карелия, Республика Татар- } \\
\text { стан, Республика Хакасия, Ростовская область, Рязанская } \\
\text { область, Самарская область, Свердловская область, Смо- } \\
\text { ленская область, Тверская область, Томская область, } \\
\text { Тульская область, Удмуртская Республика, Хабаровский } \\
\text { край, Челябинская область, Ярославская область }\end{array}$ \\
\hline $\begin{array}{l}\text { Аграрно- } \\
\text { промышленные } \\
\text { регионы }\end{array}$ & $\begin{array}{l}\text { Алтайский край, Астраханская область, Брянская об- } \\
\text { ласть, Волгоградская область, Воронежская область, } \\
\text { Евейская автономная область, Кабардино-Балкарская } \\
\text { Республика, Камчатский край, Карачаево-Черкесская } \\
\text { Республика, Кировская область, Краснодарский край, } \\
\text { Курганская область, Курская область, Оренбургская об- } \\
\text { ласть, Орловская область, Пензенская область, Псков- } \\
\text { ская область, Республика Адыгея, Республика Алтай, } \\
\text { Республика Бурятия, Республика Дагестан, Республика } \\
\text { Ингушетия, Республика Калмыкия, Республика Марий } \\
\text { Эл, Республика Мордовия, Республика Северная Осе- } \\
\text { тия-Алания, Республика Тыва, Саратовская область, } \\
\text { Ставропольский край, Тамбовская область, Ульяновская } \\
\text { область, Чеченская Республика, Чувашская Республика, } \\
\text { Амурская область, Забайкальский край, Магаданская } \\
\text { область, Чукотский автономный округ }\end{array}$ \\
\hline
\end{tabular}

Примечание. Источник: Эколого-экономический индекс регионов РФ. Методика и показатели для расчета / С. Н. Бобылев, В. С. Минаков и др. - М. : WWF России, РИА Новости, 2012. - 152 с. // https://wwf.ru/upload/iblock/dc8/index.pdf, c. 34-35. 
По результатам исследований и анализа полученных данных эколого-экономического рейтинга российских регионов, учеными были выявлены следующие результаты и закономерности:

- Регионы с низким значением рейтинга являются преимущественно регионами с преобладанием добывающего сектора, доходы которого обеспечивают бюджет территорий и социальное развитие территорий. Поэтому значительное уменьшение экологической нагрузки проблематично ввиду возможного роста социально-экономических проблем.

- Регионы-лидеры по значению эколого-экономического рейтинга - являются в основном аграрно-промышленными. Низкое значение рейтинга в значительной степени обусловлено низким уровнем развития экономики в данных регионах и существует угроза увеличения антропогенной нагрузки на окружающую среду при росте экономических показателей, что приведет к ухудшению эколого-экономического рейтинга.

По результатам анализа были выявлены следующие регионы-лидеры и регионы-аутсайдеры по значению эколого-экономического рейтинга (табл. 11 и 12).

Таблиияа 11

\section{Регионы-лидеры}

по значению эколого-экономического рейтинга

\begin{tabular}{|l|c|l|}
\hline \multicolumn{1}{|c|}{ Регион } & $\begin{array}{c}\text { Рейтинг, } \\
\text { баллы }\end{array}$ & \multicolumn{1}{|c|}{ Характеристика } \\
\hline 1. Республика Алтай & 215,37 & $\begin{array}{l}\text { Абсолютное значение ЧСН }{ }^{1} \text { невелико } \\
\text { (42,9 млрд руб.). Национальное богатство } \\
\text { формируется в основном за счет природ- } \\
\text { Hого и человеческого капитала. Объем } \\
\text { ВРП - один из самых низких в стране. Ос- } \\
\text { новной вклад в ЧСН вносят запасы леса, } \\
\text { особо охраняемые природные территории, } \\
\text { высок показатель человеческого капитала }\end{array}$ \\
\hline $\begin{array}{ll}\text { 2. Чеченская рес- } \\
\text { публика }\end{array}$ & $\begin{array}{l}\text { Наибольший вклад в ЧСН вносят вало- } \\
\text { вые накопления основного капитал, че- } \\
\text { ловеческий капитал, особо охраняемые } \\
\text { природные территории. } \\
\text { Показатель в значительной степени } \\
\text { формируется за счет средств федераль- } \\
\text { ного бюджета }\end{array}$ \\
\hline
\end{tabular}


Продолжение таблищы 11

\begin{tabular}{|c|c|c|}
\hline Регион & $\begin{array}{c}\text { Рейтинг, } \\
\text { баллы }\end{array}$ & Характеристика \\
\hline $\begin{array}{l}\text { 3. Еврейская авто- } \\
\text { номная область }\end{array}$ & 80,73 & $\begin{array}{l}\text { Наибольший вклад в ЧСН вносит уве- } \\
\text { личение запасов леса (около } 50 \text { \% ВРП). } \\
\text { Низкий уровень экологичности эконо- } \\
\text { мической деятельности } \\
\end{array}$ \\
\hline 4. Республика Тыва & 75,78 & $\begin{array}{l}\text { Абсолютное значение ЧСН невысоко, } \\
\text { что обусловлено низким уровнем разв- } \\
\text { тия экономики и низким уровнем зна- } \\
\text { чения ВРП. В структре ЧСН преобла- } \\
\text { дают запасы леса. Низкое значение ВРП } \\
\end{array}$ \\
\hline $\begin{array}{l}\text { 5. Республика Ин- } \\
\text { гушетия }\end{array}$ & 70,71 & $\begin{array}{l}\text { Высокие расходы на развитие человече- } \\
\text { ского капитала и особо охраняемые при- } \\
\text { родные территории. Абсолютное значе- } \\
\text { ние ЧСН невысоко, Высокий рейтинг } \\
\text { обусловлен низким значением ВРП } \\
\end{array}$ \\
\hline $\begin{array}{l}\text { 6. Краснодарский } \\
\text { край }\end{array}$ & 68,97 & $\begin{array}{l}\text { Высокий уровень экономического раз- } \\
\text { вития. Один из лидеров среди россий- } \\
\text { ских регионов по показателю «валовые } \\
\text { отношения основного капитала / ВРП» } \\
\text { (5-е место). Ущерб от загрязнений ком- } \\
\text { пенсируется инвестициями в человече- } \\
\text { ский капитал, наличием особо охраняе- } \\
\text { мых природных территорий. Величина } \\
\text { ущерба в абсолютных значениях не } \\
\text { очень велика }\end{array}$ \\
\hline 7. Тверская область & 64,41 & $\begin{array}{l}\text { Высокое значение не только индекса } \\
\text { СЧН (относительный показатель), но } \\
\text { абсолютного значения СЧН (11 место } \\
\text { среди регионов России). Одним из ос- } \\
\text { новных факторов, обусловивших высо- } \\
\text { кое значение СЧН является наличие } \\
\text { особо охраняемых природных террито- } \\
\text { рий и увеличение лесных ресурсов }\end{array}$ \\
\hline $\begin{array}{l}\text { 8. Кабардино- } \\
\text { Балкарская область }\end{array}$ & 63,77 & $\begin{array}{l}\text { Высокое значение в рейтинге обуслов- } \\
\text { лено наличием особо охраняемых при- } \\
\text { родных территорий }\end{array}$ \\
\hline $\begin{array}{l}\text { 9. Республика Кал- } \\
\text { мыкия }\end{array}$ & 62,13 & $\begin{array}{l}\text { Отмечается высокое значение инвести- } \\
\text { ций в развитие человеческого капитала. } \\
\text { Ущерб от истощения природных ресур- } \\
\text { сов находится на низком уровне } \\
\end{array}$ \\
\hline
\end{tabular}


Окончание таблицы 11

\begin{tabular}{|l|c|l|}
\hline \multicolumn{1}{|c|}{ Регион } & $\begin{array}{c}\text { Рейтинг, } \\
\text { баллы }\end{array}$ & \multicolumn{1}{c|}{ Характеристика } \\
\hline $\begin{array}{l}\text { 10. Республика } \\
\text { Адыгея }\end{array}$ & 61,74 & $\begin{array}{l}\text { Характерны низкие значения абсолют- } \\
\text { ных вредных выбросов в окружающую } \\
\text { среду. Наибольший вклад в формирова- } \\
\text { ние индекса СЧН вносят валовые нако- } \\
\end{array}$ \\
& $\begin{array}{l}\text { пления основного капитала и особо ох- } \\
\text { раняемые природные территории }\end{array}$ \\
\hline
\end{tabular}

Примечания: ${ }^{1}$ ЧСН - чистые скорректированные накопления.

Источник: Эколого-экономический индекс регионов РФ. Методика и показатели для расчета / С. Н. Бобылев, В. С. Минаков и др. - M. : WWF России, РИА Новости, 2012. - 152 с. // https://wwf.ru/upload/iblock/dc8/index.pdf, c. 131-135.

Таблица 12

\section{Регионы-аутсайдеры}

по значению эколого-экономического рейтинга

\begin{tabular}{|c|c|c|}
\hline Регион & $\begin{array}{c}\text { Рейтинг, } \\
\text { баллы }\end{array}$ & Характеристика \\
\hline $\begin{array}{l}\text { 1. Ненецкий авто- } \\
\text { номный округ }\end{array}$ & $-76,29$ & $\begin{array}{l}\text { Низкий рейтинг обусловлен сырьевой } \\
\text { ориентацией региона, что приводит к } \\
\text { истощению природных ресурсов. } \\
\text { В структуре ВРП преобладают инве- } \\
\text { стиции в добывающий сектор }\end{array}$ \\
\hline $\begin{array}{l}\text { 2. Ханты- } \\
\text { Мансийский aвто- } \\
\text { номный округ-Югра }\end{array}$ & $-45,69$ & $\begin{array}{l}\text { Характеризуется значительными объ- } \\
\text { емами добычи природных ресурсов. } \\
\text { ХМАО сокращает свои природные ре- } \\
\text { сурсы, но является обеспечивающим } \\
\text { инвестиции и развитие других регио- } \\
\text { нов. Относительно невысокий объем } \\
\text { вредных выбросов. Высокий абсолют- } \\
\text { ный объем расходов на охрану окру- } \\
\text { жающей среды. Четверное место сре- } \\
\text { ди регионов по объему инвестиций в } \\
\text { развитие человеческого потенциала. } \\
\text { Второе место по объему затрат на ох- } \\
\text { рану окружающей среды }\end{array}$ \\
\hline $\begin{array}{l}\text { 3. Сахалинская об- } \\
\text { ласть }\end{array}$ & $-33,34$ & $\begin{array}{l}\text { Значительное истощение природные } \\
\text { ресурсов, высокая доля добывающей } \\
\text { промышленности в структуре ВРП. } \\
\text { Ущерб от вредных выбросов относи- } \\
\text { тельно невысок }\end{array}$ \\
\hline
\end{tabular}


Окончание таблицы 12

\begin{tabular}{|c|c|c|}
\hline Регион & $\begin{array}{c}\text { Рейтинг, } \\
\text { баллы }\end{array}$ & Характеристика \\
\hline $\begin{array}{l}\text { 4. Чукотский авто- } \\
\text { номный округ }\end{array}$ & $-28,73$ & $\begin{array}{l}\text { Истощение природных ресурсов не } \\
\text { компенсируется затратами на охрану } \\
\text { окружающей среды и инвестициями в } \\
\text { развитие человеческого капитала. } \\
\text { Ущерб от вредных выбросов относи- } \\
\text { тельно высок }\end{array}$ \\
\hline $\begin{array}{l}\text { 5. Тюменская об- } \\
\text { ласть }\end{array}$ & $-28,39$ & $\begin{array}{l}\text { Значительное исчерпание природных } \\
\text { ресурсов. } \\
\text { Область является регионом-донором. } \\
\text { Первое место среди регионов по объему } \\
\text { затрат на охрану окружающей среды, } \\
19 \text { место - по объему инвестиций в раз- } \\
\text { витие человеческого потенциала }\end{array}$ \\
\hline $\begin{array}{l}\text { 6. Оренбургская об- } \\
\text { ласть }\end{array}$ & $-26,87$ & $\begin{array}{l}\text { Значительное истощение природных } \\
\text { ресурсов, превышающее валовое на- } \\
\text { копление основного капитала }\end{array}$ \\
\hline $\begin{array}{l}\text { 7. Ямало-Ненецкий } \\
\text { автономный округ }\end{array}$ & $-21,98$ & $\begin{array}{l}\text { Существенное исчерпание природных } \\
\text { ресурсов. Один из основных добы- } \\
\text { вающих регионов. Доходы от добычи } \\
\text { природных ресурсов используются в } \\
\text { федеральном масштабе }\end{array}$ \\
\hline $\begin{array}{l}\text { 8. Кемеровская об- } \\
\text { ласть }\end{array}$ & $-19,84$ & $\begin{array}{l}\text { Достаточно высокие удельные выбро- } \\
\text { сы вредных веществ. Отношение } \\
\text { ущерба в ВРП - одно из самых высо- } \\
\text { ких в России }\end{array}$ \\
\hline $\begin{array}{l}\text { 9. Иркутская об- } \\
\text { ласть }\end{array}$ & $-9,04$ & $\begin{array}{l}\text { Существенное сокращение запасов } \\
\text { леса. Относительно низкое значение } \\
\text { экологической деятельности. Отноше- } \\
\text { ние ущерба в ВРП - выше среднерос- } \\
\text { сийских показателей. Как положи- } \\
\text { тельные характеристики отмечается } \\
\text { наличие на территории области особо } \\
\text { охраняемых природных территорий }\end{array}$ \\
\hline $\begin{array}{l}\text { 10. Костромская } \\
\text { область }\end{array}$ & $-3,04$ & $\begin{array}{l}\text { Довольно высокий ущерб от загрязне- } \\
\text { ний окружающей среды. Сокращаются } \\
\text { запасы леса. Низкий объем валовых } \\
\text { накоплений }\end{array}$ \\
\hline
\end{tabular}

Примечание. Источник: Эколого-экономический индекс регионов РФ. Методика и показатели для расчета / С. Н. Бобылев, В. С. Минаков и др. - М. : WWF России, РИА Новости, 2012. - 152 c. // https://wwf.ru/upload/iblock/dc8/index.pdf, c. $136-142$. 
Предложенный коллективом ученых (Бобылев С.Н., Минаков В.С., Соловьева С.В., Третьяков В.В.) расчет эколого-экономического индекса регионов России обладает следующими преимуществами:

- основан на использовании открытых статистических данных;

- позволяет сравнивать данные как в динамике, так и между регионами;

- возможен для оценки улучшения качества экономического роста;авторы индекса считают, что предложенный подход «позволит начать внедрение оплаты т.н. «экосистемных услуг» тем регионам, которые больше всего вкладываются в сохранение природного наследия...» ${ }^{16}$;

- индекс возможно применять для анализа и корректировки эколого-экономической политики регионов.

Отметим и недостатки предложенного подхода:

- для определения рейтинга требуется анализ большого объема данных, используемые статистические данные несовершенны;

- расчет индекса довольно трудоемок, расчеты представлены для всех российских регионов, но только для 2012 г.;

- рейтинг не позволяет дать однозначную оценку эффективности управленческих решений относительно реализации эколого-экономической политики региона: так, добывающие регионы с низким показателем рейтинга являются донорами бюджетов других территорий ${ }^{17}$, при этом на собственной территории не обеспечивается воспроизводство природных ресурсов.

Выводы. В мировой и российской практике разработаны отдельные индикаторы и системы индикаторов, характеризующие оценку влияния человека на окружающую среду и различные аспекты устойчивого развития территорий. Наиболее известны и широко используются такие индикаторы как: показатели ресурсоемкости, показатели интенсивности загрязнений, цели устойчи-

16 Эколого-экономический индекс регионов РФ. Методика и показатели для расчета / С.Н. Бобылев, В.С. Минаков и др. - М. : WWF России, РИА Новости, 2012. - 152 с. // https://wwf.ru/upload/iblock/dc8/index.pdf, c. 141.

${ }^{17}$ Посредством перераспределения налогов. 
вого развития; а также интегральные индексы: индекс развития человеческого потенциала, индекс счастья, экологический след, индекс «живой планеты», индекс скорректированных чистых накоплений.

Показатели и индексы рассчитываются на основе как статистических данных, так и экспертных оценок. Имеются регулярные оценки по странам и регионам, что позволяет провести сравнение и оценить усилия отдельных государств в борьбе с глобальными экологическими проблемами. Отметим, что расчет показателей достаточно сложен и трудоемок.

Для оценки эколого-экономического развития территорий наибольшее признание в российской практике получил показатель скорректированных чистых накоплений (Adjusted Net Saving), на основе которого исследователями (Бобылев С.Н. и др.) предложен показатель «эколого-экономический индекс регионов РФ». Показатель был рассчитан для российских регионов за 2012 г., что сделало возможным проанализировать данные между регионами и выявить региональную специфику, но отсутствие расчетов в динамике не позволило оценить эффективность управленческих решений региональных органов власти.

Все изученные индикаторы и системы индикаторов не позволяют сделать однозначные выводы о взаимозависимости экономического развития регионов и территорий и росте/уменьшении экологических угроз и дать оценку эколого-экономических рисков регионов. Данный подход важен, по нашему мнению: 1) для инвесторов, реализующих проекты экологической направленности в регионах: с точки зрения современной концепции устойчивого роста и «зеленой экономики» им важно знать, насколько экономическая эффективность соотносится с изменением экологической нагрузки в регионе; 2) для региональных органов власти и общественности: как инструмент для оценки усилий и эффективности регионов в области «зеленого» развития, которое предполагает необходимость экономического роста при сокращении вредного воздействия на окружающую среду. С целью решения данных проблем автором был предложена методика декаплинг-анализа, позволяющая оценить эколого-экономичес- 
кое развитие регионов и ранжировать их по рейтингу «экологоэкономической привлекательности».

\section{2. Аналитический инструментарий информационного обеспечения устойчивого развития территорий: методика углубленного декаплинг-анализа}

Для анализа эколого-экономического состояния регионов в мировой практике используется индекс декаплинга ${ }^{18}$. Он характеризует эффект «декаплинга», то есть «расщепление», «разъединение» темпов роста показателей экономического роста (ВВП, ВРП) и темпов роста потребления природных ресурсов и отходов производства и потребления. Наличие эффекта декаплинга является необходимым условием устойчивого развития регионов. Оценка эффекта «декаплинга» в региональной экономике позволит ранжировать регионы по уровню эколого-экономического развития, сделать выводы об эффективности эколого-экономической политики регионов.

О важности и необходимости эффекта декаплинга для российской экономики в современных условиях говорит в своих выступлениях и докладах Бобылев С.Н. - д-р экон. наук., зав. кафедрой экономики природопользования МГУ, профессор, заслуженный деятель науки РФ ${ }^{19}$.

В исследованиях Думнова А.Д., Борискина Д.А., Рыбальского Н.Г. отмечается упрощенный подход к выводам, которые можно сделать на основе традиционного декаплинг-анализа, а также говорится о том, что «осознание показателей декаплинга...

${ }^{18}$ System of Environment-Ecomonic Accounting 2012 : Applications and Extensions (White cover publication/ pre-edited text subject to official editing). Eurorean Commission, FAO, OECD, United Natoins, World Bank, 2014b.

${ }^{19}$ Бобылев С.Н. Экологические приоритеты для России // https:/pptonline.org/355370; Устойчивое развитие: новые вызовы / колл. авторов. - М.: Издательство «ПАспект Пресс», 2015 - 336 с., с. 57. 
со стороны отдельных ученых и специалистов в России серьезно задержалось» ${ }^{20}$.

Анализ эффекта «декаплинг»а по ряду российских регионов и отраслей был представлен в работах исследователей: Акулова А.О. ${ }^{21}$, Кирилова С.Н. и коллектива ученых ${ }^{22}$, Самариной В.П. ${ }^{23}$, Шкиперова Г.И. ${ }^{24}$, Яковлевой Е.Ю. ${ }^{25}$, Яшаловой Н.Н. ${ }^{26}$.

При общеметодологическом единстве к пониманию сущности эффекта декаплинга применяемые на практике методики расчета данного эффекта различны в отношении используемых показателях и формул расчета. Так, исследователи используют при анализе следующие показатели ${ }^{27}$ : экономические - валовой региональный продукт, объем промышленного производства, рост благосостояния населения; показатели антропогенного воздействия на окружающую среду - это индикаторы как показатели загрязнения окружающей среды; оценку ресурсосбережения проводят, анализируя специфические отраслевые показатели, например, для горнодобывающих отраслей: объемы добычи руды, площадь от-

${ }^{20}$ Думнов А.Д., Борискин Д.А., Рыбальский Н.Г. Онекоторых методах макростатистического анализа природопользования и охраны окружующей среды // Век глобализации. - 2017 - № 2. - С. 37-50, с. 45.

${ }^{21}$ Акулов А.О. Эффект декаплинга в индустриальном регионе (на примере Кемеровской области) // Экономические и социальные перемены: факты, тенденции, прогноз. - 2013. - № 4 (28). - С. 177-185.

${ }^{22}$ Кириллов С.Н., Пакина А.А., Тульская Н.И. Оценка устойчивости развития на региональном уровне: пример Республики Татарстан // Вестник ВолГУ. Серия 3, Экономика, Экология. - 2017. - № 4. - С. 127-137.

${ }^{23}$ Самарина В.П. «Зеленая» экономика России: некоторые вопросы теории и методологии // Национальные интересы: приоритеты и безопасность. 2015. - № 2 (287). - С. 2-9.

${ }^{24}$ Шкиперова Г.И. Анализ моделирования взаимосвязи между экономическим ростом и качеством окружающей среды (на примере Республике Карелия) // Экономический анализ: теория и практика. - 2014. - № 43 (394). - С. 41-49.

25 Яковлева Е.Ю. Экономическая оценка межотраслевых потоков природных ресурсов и загрязнений : дис. ... канд. экон. наук: 08.00.05.- М., 2016, 169 с.

26 Яшалова Н.Н. Анализ проявления эффекта декаплинга в эколого-экономической деятельности региона // Региональная экономика: теория и практика. - 2014. - 39 (366). - С. 54-60.

27 Там же, с. 4. 
торгаемых земель, площадь земель с нарушенным водным балансом и т. п., а также показатели эколого-экономического учета.

Проведенные исследования по отдельным российским регионам показали следующие результаты:

А) наличие эффекта декаплинга в Мурманской области ${ }^{28}$ (по связи между показателями выбросов в атмосферу загрязняющих веществ от стационарных источников и динамикой ВРП), в Белгородской области (уменьшение выбросоватмосферу загрязняющих веществ от стационарных источников и улучшение химического состава поверхностных вод), в Краснодарском крае (взаимосвязь между показателями промышленного производства и атмосферными выбросами), в Республике Татарстан ${ }^{29}$.

Б) отрицательный эффект декаплинга в Ростовской области ${ }^{30}$ (рост загрязнения окружающей природной среды после сокращения интенсивности промышленного производства), в Кемеровской области по угольной промышленности ${ }^{31}$, в Республике Карелия $^{32}$ (положительный - по отношению к выбросам загрязняющих веществ от стационарных источников и отрицательный по прогнозу долгосрочной перспективе);

В) положительный эффект декаплинга в Вологодской области по металлургической отрасли и незначительный - по химической ${ }^{33}$.

${ }^{28}$ Указ. соч. С. 4.

${ }^{29}$ Кириллов С.Н., Пакина А.А., Тульская Н.И. Оценка устойчивости развития на региональном уровне: пример Республики Татарстан // Вестник ВолГУ. Серия 3, Экономика, Экология. - 2017. - № 4. - С. 127-137.

30 Там же.

${ }^{31}$ Акулов А.О. Эффект декаплинга в индустриальном регионе (на примере Кемеровской области) // Экономические и социальные перемены: факты, тенденции, прогноз. - 2013. - № 4 (28). - С. 177-185.

32 Шкиперова Г.И. Анализ моделирования взаимосвязи между экономическим ростом и качеством окружающей среды (на примере Республике Карелия) // Экономический анализ: теория и практика. - 2014. - № 43 (394). - С. 41-49.

33 Яшалова Н.Н. Анализ проявления эффекта декаплинга в эколого-экономической деятельности региона // Региональная экономика: теория и практика. - 2014. - 39 (366). - С. 54-60. 
В исследовании Яковлевой Е.Ю. ${ }^{34}$ проведена оценка потоков природных ресурсов и загрязнений для регионов и отраслей экономики России. Эффект декаплинга рассчитан по показателям использования воды, сброса сточных вод, загрязнения атмосферного воздуха от передвижных и стационарных источников в целом, в также отдельно по оксиду углерода, диоксиду серы, оксидам азота, углеводородам, летучим органическим соединениям, твердым частицам по федеральным округам России. Яковлева Е.Ю. показала, что «по всем указанным ресурсам и загрязнениям в России и отдельных федеральных округах наблюдается абсолютный или относительный эффект декаплинга» ${ }^{35}$. По 80 российских регионам ею проведена динамическая оценка эколого-экономической «успешности» региона, позволяющая составить ренгинг регионов по уровню влияния экономической деятельности на окружающую среду.

В тоже время отметим, что системные исследования, посвященные оценке экономико-экологической эффективности Волгоградской области в научной литературе широко не представлены. В уже отмеченном исследовании Яковлевой Е.Ю. Волгоградская область отнесена к среднеразвитым агропромышленным районам, уровень эколого-экономической «успешности» региона стабильно увеличивается незначительными темпами (с 0,531 в 2007 г. до 0,604 в 2013 г., из максимально возможно значения уровня $-1,00)^{36}$.

Показатель декаплинга отражает экстенсивность или интенсивность развития экономики по отношению использованию при-

34 Яковлева Е.Ю. Экономическая оценка межотраслевых потоков природных ресурсов и загрязнений : дис. ... канд. экон. наук: 08.00.05. - М., 2016, $169 \mathrm{c.}$

35 Яковлева Е.Ю. Экономическая оценка межотраслевых потоков природных ресурсов и загрязнений : дис. ... канд. экон. наук: 08.00.05. - М., 2016, 169 c., c. 7.

36 Яковлева Е.Ю. Экономическая оценка межотраслевых потоков природных ресурсов и загрязнений : дис. ... канд. экон. наук: 08.00.05. - М., 2016, 169 c., c. 160. 
родных ресурсов и условий окружающей среды. Различают следующие виды декаплинга ${ }^{37}$ :

1) ресурсный декаплинг (recourse decoupling) - характеризуется снижением ресурсоемкости производства, то есть происходит снижение использования сырья, энергии, водных и земельных ресурсов на единицу продукции или наблюдается рост ВВП (ВРП, индекса производства) по отношению к объему используемых ресурсов; направлен на снижение воздействия на окружающую среду, происходит экономия затрат на производство, повышается интенсивность производственного процесса и ресурсоэффективность;

2) декаплинг воздействия (impact decoupling) - происходит снижение негативного воздействия на окружающую среду в процессе производства, потребления и после потребления, выявляется на основе анализа жизненного цикла и построение моделей межотраслевого баланса;

3) относительный декаплинг - при котором результирующий показатель (показатель экономического роста) растет быстрее экологического показателя (затраты ресурсов или загрязнения окружающий среды);

4) абсолютный декаплинг - рост экономического показателя при снижении экологического.

Исследователи отмечают актуальность анализа эффекта декаплинга: «использование коэффициента декаплинга для оценки устойчивости развития открывает в дальнейшем перспективы для работ методического характера: предложения по классификации показателей декаплинга для разных видов природопользования будут способствовать формированию методики оценки устойчивости на региональном уровне ${ }^{38}$. Иллюстрация эффекта декаплинга представлена на рисунке 4.

37 Яковлева Е.Ю. Экономическая оценка межотраслевых потоков природных ресурсов и загрязнений : дис. ... канд. экон. наук: 08.00.05. - М., 2016, 169 с., с. 21-22.

${ }^{38}$ Кириллов С.Н., Пакина А.А., Тульская Н.И. Оценка устойчивости развития на региональном уровне: пример Республики Татарстан // Вестник ВолГУ. Серия 3, Экономика, Экология. - 2017. - № 4. - с. 127-137, с. 133. 


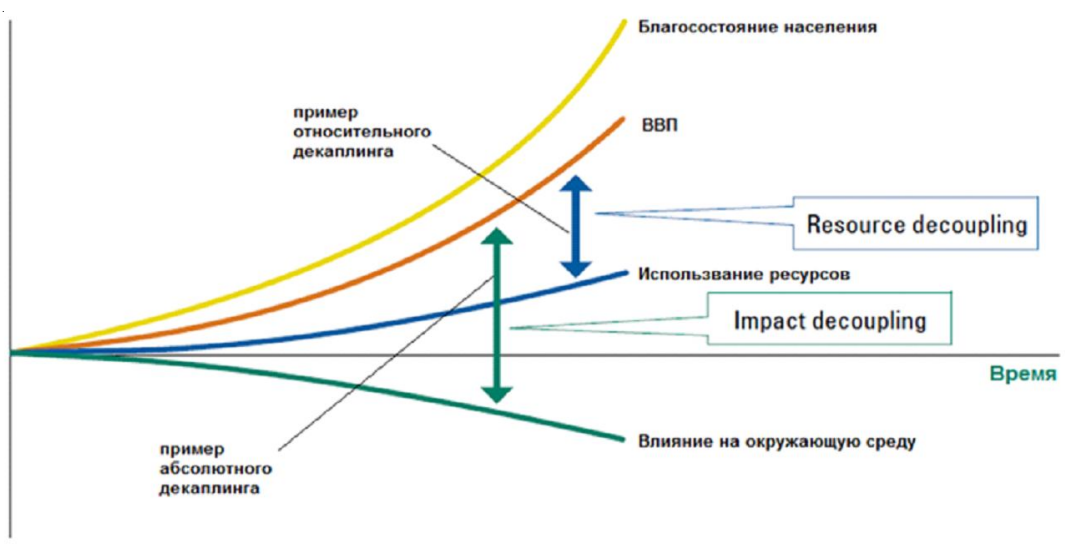

Рис. 4. Эффект декаплинга

Примечание. Источник: Бобылев С.Н. Экологические приоритеты для России // https://ppt-online.org/355370.

Для нашего исследования уточним цели, принципы и модель углубленного декаплинг-анализа ${ }^{39}$.

Целями разработки индикаторов социально-экономического развития регионов являются:

1. Принятие управленческих решений:

- при разработке стратегий, программ планов развития регионов;

- при прогнозировании ожидаемых эколого-экономических эффектов;

- при мониторинге реализации региональных стратегий, программа, планов;

- при оценке и корректировке стратегий, планов и программ.

2. Анализ данных:

- для сравнения, оценки данных на уровне макро- , мезо- и микроэкономики (стран, регионов, отраслей, компаний);

${ }^{39}$ Методика приведена в статье: Anikina I., Anikin A., Gukova A. Decoupling” effect as a factor of regional sustainable development (evidence from Volgograd Region) // Proceedings of the International Scientific Conference «Competitive, Sustainable and Secure Development of the Regional Economy: Response to Global Challenges» (CSSDRE 2018) // https://www.atlantis-press.com/proceedings/cssdre-18/25896426. 
- для выявления тенденций эколого-экономического развития регионов.

3. Информирование всех стейкхолдеров (органы власти государства и регионов, общественность, инвесторов, организации) об эколого-экономическом состоянии регионов для принятия различных управленческих решений.

Принципы разработки индикаторов эколого-экономического развития регионов

1. Принцип динамики: индикаторы должны обеспечивать возможность анализа динамики изменений, мониторинга эффективности деятельности, оценку направленности изменений (негативное или позитивное).

2. Принции информированности (полезности) : индикаторы должны обеспечивать обоснованную информацию для принятия управленческих решений, индикаторы должны отражать информацию о существенных проблемах эколого-экономических проблемах.

3. Принции учета интересов стейкхолдеров: индикаторы должны быть понятными для стейкхолдеров; индикаторы должны отражать информацию, полезную для принятия решений многими экономическими субъектами.

4. Принщии достоверности: индикаторы должны отражать существенную информацию, полезную для принятия решений; затраты на получение и обработку информации необходимо соотносить с полезностью их использования, данные для расчета индикаторов должны обеспечивать достоверность, точность, надежность, необходимую частоту расчетов;

Выделим дополнительно к принципам следующие критерии, которым должны удовлетворять индикаторы: количественная оценка; использование данных только официальной статистики; отсутствие экспертных оценочных суждений; возможность оценки в динамике, по уровням экономической системы (макро-, мезо-, микроуровни), по секторам экономики; конечное число индикаторов.

\section{Метод углубленного декаплинг-анализа.}

Эффект «декаплинга» оценивается на основе индекса декаплинга (DI) за определенный период времени (как правило, год) по формуле (7): 


$$
\mathbf{D I}=\mathbf{T}_{\mathbf{R}} \times \mathbf{T}_{\mathbf{Y}},
$$

где $\mathrm{T}_{\mathrm{R}}$ - относительное изменение (коэффициент роста) потребляемого ресурса или выброса загрязнения за определенный период; $\mathrm{T}_{\mathrm{y}}$ - относительное изменение (коэффициент роста) результирующего показателя (как правило ВВП, ВРП, т. п.) за аналогичный период; DI - индекс декаплинга, выраженный в относительных единицах;

при DI > 1,0 - эффект «декаплинга» отсутствует - потребление ресурсов или загрязнение окружающей среды происходит более быстрыми темпами, чем экономический рост, происходит интенсивное загрязнение окружающей среды; при DI = 1,0 темпы экономического роста и загрязнения окружающей среды одинаковы; при 1,0 < DI наблюдается эффект «декаплинга» - темпы экономического роста выше, чем темпы загрязнения окружающей среды.

Индекс декаплинга, рассчитанный по формуле (7), дает возможность оценить наличие эффекта «декаплинга», но не показывает, является ли этот эффект абсолютным или относительным. Также отсутствует возможность более глубоких выводов об эколого-экономическом состоянии региона. Для преодоления этих недостатков авторами предлагается модель анализа эффекта «декаплинга». Модель (рис. 5) основана на сопоставлении коэффициентов прироста потребляемых ресурсов и/или загрязнений и показателями экономического роста. Скорректированный индекс декаплинга в модели рассчитывается по следующей формуле (8):

$$
\mathbf{D I}=\mathbf{T}_{\mathbf{R}}{ }^{\prime}-\mathbf{T}_{\mathbf{Y}}{ }^{\prime},
$$

где $\mathrm{DI}^{\prime}$ - скорректированный индекс декаплинга, выраженный в относительных единицах; $\mathrm{T}_{\mathrm{R}}{ }^{\prime}$ - коэффициент прироста потребляемого ресурса или выброса загрязнения за определенный период, отн. Ед., $\mathrm{T}_{\mathrm{Y}}^{\prime}$ - коэффициент прироста результирующего показателя за аналогичный период, отн. Ед.

Модель позволяет выделить шесть секторов, характеризующих различную степень эффективности эколого-экономического состояния региона. На рисунке 5 секторы пронумерованы от наилучшего к наихудшему. 
Сектор I: $\mathrm{T}_{\mathrm{R}}^{\prime}(-)<\mathrm{T}_{\mathrm{Y}}^{\prime}(+), \mathrm{DI}^{\prime}<0$. Наличие эффекта «абсолютного декаплинга». Наиболее благоприятная ситуация для экономики региона, характеризующаяся снижением экологической нагрузки в регионе при одновременном экономическом росте, устойчивое развитие региона.

Сектор II: $\mathrm{T}_{\mathrm{R}}{ }^{\prime}(+; 0,0)<\mathrm{T}_{\mathrm{Y}}^{\prime}(+), \mathrm{DI}^{\prime}<0,0$ либо $=0,0$. Наличие эффекта «относительного декаплинга». «Нормальный экономический рост». Нормальная ситуация, рост эффективности экономики региона сопровождается ростом экологических издержек, растет негативное воздействие на окружающую среду, но индекс декаплинга остается отрицательной величиной, что говорит об устойчивом развитии региона.

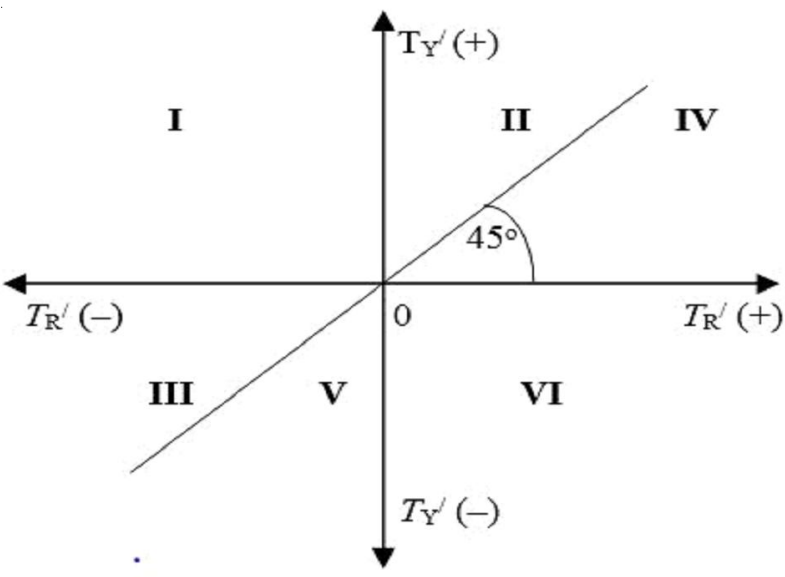

Рис. 5. Модель оценки эффекта декаплинга

Примечание. Источник: авторская модель.

Сектор III: $\mathrm{T}_{\mathrm{R}}^{\prime}(-; 0,0)>\mathrm{T}_{\mathrm{Y}}^{\prime}(-; 0,0), \mathrm{DI}^{\prime}<0,0$ либо $=0,0$. Наличие эффекта «относительного декаплинга». Ситуация характеризуется снижением экологической нагрузки на регион при одновременном снижении ВРП, но экологическая нагрузка снижается быстрее экономических результатов. Такая ситуация возможна в условиях реструктуризации производств, перехода на новые инновационные технологии. 
Сектор IV: $\mathrm{T}_{\mathrm{R}}^{\prime}(+)>\mathrm{T}_{\mathrm{Y}}^{\prime}(+), \mathrm{DI}^{\prime}>0$. Эффект «декаплинга» отсутствует. Замедление эффективности эколого-экономического развития региона. «Бурый» экономический рост. Происходит ускоренная нагрузка на экологическое состояние региона, но наблюдается и экономический рост. Необходимо уделять внимание поддержке «зеленых» технологий и проектов.

Сектор V: $\mathrm{T}_{\mathrm{R}}^{\prime}(-)<\mathrm{T}_{\mathrm{Y}}^{\prime}(-), \mathrm{DI}^{\prime}>0$. Эффект «декаплинга» отсутствует. Для данной ситуации характерно снижение экологической нагрузки при одновременно большем ухудшении показателей эффективности региональной экономики.

Сектор VI: $\mathrm{T}_{\mathrm{R}}{ }^{\prime}(+)>\mathrm{T}_{\mathrm{Y}}{ }^{\prime}(-), \mathrm{DI}^{\prime}>0$. Эффект «декаплинга» отсутствует. Наихудшая, кризисная ситуация, при которой рост нагрузки на экологию региона сопровождается ухудшением экономической ситуации.

Предложенная модель позволяет выявить секторы, характеризующие качественно различную степень эффективности реализации эколого-экономической политики региона, что поможет своевременно диагностировать экологические и экономические проблемы региона и принять соответствующие решения о мерах поддержки экологических проектов и программ, целесообразности их продолжения, корректировки, реструктуризации.

На основе скорректированного индекса декаплинга предлагается рассчитывать рейтинг «эколого-экономической привлекательности» региона (формула 9):

$$
\text { Reea }=\sum \mathbf{r}_{\mathbf{i}} * \mathbf{f}_{\mathbf{i}} / \sum \mathbf{f}_{\mathbf{i}}
$$

где Reea - рейтинг эколого-экономической привлекательности региона; Reea $=[1 \div 6] ; r_{i}-$ номер сектора декаплинг-анализа, $\mathrm{ri}=[1,2, \ldots 6] ; \mathrm{f}_{\mathrm{i}}-$ номер анализируемого периода, $\mathrm{fi}=[1,2, \ldots \mathrm{n}] ; \mathrm{n}-$ количество анализируемых периодов.

Рейтинг может быть использован инвесторами для оценки региональных рисков при инвестировании в региональные экологические проекты.

Вывод: целью исследования явилась разработка модели углубленного декаплинг-анализа. Предложенные модели и могут 
быть использованы для мониторинга эколого-экономического состояния региона, а также при разработке и корректировке эколого-экономических программ развития регионов.

Представленную модель анализа эффекта «декаплинга» считаем возможным применить для оценки эколого-экономического состояния регионов и механизмов поддержки «зеленых» проектов, для мониторинга внедрения инновационных эколого-сберегающих технологий. Оценка не только наличия или отсутствия эффекта «декаплинга», но и его более глубокий анализ, позволит делать выводы об инвестиционной привлекательности региона для внедрения инновационных проектов в области «зеленых» технологий, выбору оптимальных источников финансирования и их параметров.

\section{3. Оценка эффекта декаплинга на примере российских регионов}

В России вопросы экологической безопасности в настоящее время находятся в числе приоритетов государственной политики, что отражается в принятии значительного количества нормативных документов и программ, направленных на стимулирование «зеленых» инвестиций и инноваций, сохранение и восстановление экосреды. 2017 год был объявлен в России Годом экологии и, как отмечается в Указе Президента Российской Федерации, целью Года экологии являлось «привлечения внимания общества к вопросам экологического развития Российской Федерации, сохранения биологического разнообразия и обеспечения экологической безопасности» ${ }^{40}$. Как отмечается Министерством природных ресурсов и экологии Российской Федерации «ключевые решения года - внедрение наилучших доступных природоохранных технологий, улучше-

${ }^{40}$ Указ Президента Российской Федерации от 05.01.2016 г. № 7 «О проведении в Российской Федерации года экологии» // http://kremlin.ru/events/president/ news/51142. 
ние экологических показателей регионов, совершенствование системы управления отходами, защита Байкальской природной территории, сохранение водных, лесных и земельных ресурсов, развитие заповедной системы» ${ }^{41}$.

Сложившая к настоящему времени в России экологическая обстановка оценивается как небезопасная, отмечается в Стратегии экологической безопасности Российской Федерации на период до 2025 года: «Состояние окружающей среды на территории Российской Федерации, где сосредоточены большая часть населения страны, производственных мощностей и наиболее продуктивные сельскохозяйственные угодья (составляет около 15 процентов территории страны), оценивается как неблагополучное по экологическим параметрам. ...По экспертным оценкам, ежегодно экономические потери, обусловленные ухудшением качества окружающей среды и связанными с ним экономическими факторами, без учета ущерба здоровью людей, составляют 4-6 процентов валового внутреннего продукта» ${ }^{42}$.

Сама Стратегия экологической безопасности Российской Федерации на период до 2025 года была принята впервые в 2017 году, который был объявлен в России Годом экологии, что свидетельствует о высокой актуальности исследований по экологической тематике.

Авторы провели декаплинг-анализ российских регионов с целью оценки их эколого-экономического состояния, также рассчитан рейтинг «эколого-экономической привлекательности» регионов. Расчет по предложенной авторами модели по 80 российским регионам приведен в таблице приложений А.

\section{Методика оценки эколого-экономического состояния} российских регионов (табл. 13).

${ }^{41} \mathrm{http}: / /$ ecoyear.ru/about/.

42 Стратегия экологической безопасности Российской Федерации на период до 2025 года. Указ Президента России № 176 от 19.04.2017 // kremlin.ru/acts/ bank/41879/page/1. 
Таблица 13

\section{Этапы оценки эколого-экономического состояния регионов}

\begin{tabular}{|c|c|c|c|}
\hline $\begin{array}{c}\text { № } \\
\text { ПI/II }\end{array}$ & Этапы & \multicolumn{2}{|c|}{ Характеристика этапов } \\
\hline 1 & $\begin{array}{l}\text { Исходные дан- } \\
\text { ные }\end{array}$ & \multicolumn{2}{|c|}{$\begin{array}{l}\text { - выбросы загрязняющих веществ от стационар- } \\
\text { ных источников, тыс. тонн; } \\
\text { - сброс загрязненных сточных вод в поверхност- } \\
\text { ные водные объекты, млн. куб.м.; } \\
\text { - индексы физического объема валового регио- } \\
\text { нального продукта; } \\
\text { - индексы физического объема валового регио- } \\
\text { нального продукта на душу населения; } \\
\text { - численность населения, тыс. чел. }\end{array}$} \\
\hline 2 & $\begin{array}{l}\text { Расчет индек- } \\
\text { сов декаплинга }\end{array}$ & \multicolumn{2}{|c|}{$\begin{array}{l}\text { 1) DI = TR / TY, } \\
\text { где TR - относительное изменение (коэффициент роста) } \\
\text { потребляемого ресурса или выброса загрязнения за опре- } \\
\text { деленный период; Ту - относительное изменение (коэф- } \\
\text { фициент роста) результирующего показателя (как правило } \\
\text { ВВП, ВРП, т.п.) за аналогичный период; DI - индекс де- } \\
\text { каплинга, выраженный в относительных единицах; } \\
\text { 2) DI/ = TR / - TY /, } \\
\text { где DI/ - скорректированный индекс декаплинга, выра- } \\
\text { женный в относительных единицах; TR/ - коэффициент } \\
\text { прироста потребляемого ресурса или выброса загрязне- } \\
\text { ния за определенный период, отн. ед., ТY/ - коэффици- } \\
\text { ент прироста результирующего показателя за аналогич- } \\
\text { ный период, отн. ед. }\end{array}$} \\
\hline \multirow[t]{4}{*}{3} & \multirow{4}{*}{$\begin{array}{l}\text { Определение } \\
\text { сектора в мо- } \\
\text { дель оценки эф- } \\
\text { фекта декаплин- } \\
\text { га и его харак- } \\
\text { теристика }\end{array}$} & Наличие эффекта декаплинга & $\begin{array}{c}\text { Отсутствие эффек- } \\
\text { та декаплинга }\end{array}$ \\
\hline & & $\begin{array}{c}\text { Сектор I. } \\
\mathrm{TR} /(-; 0,0)<\mathrm{TY} /(+, 0,0), \\
\mathrm{DI} / \leq 0,0\end{array}$ & $\begin{array}{c}\text { Сектор IV } \\
\mathrm{TR} /(+)>\mathrm{TY} /(+), \\
\mathrm{DI} />0\end{array}$ \\
\hline & & $\begin{array}{c}\text { Сектор II. } \\
\mathrm{TR} /(+; 0,0)<\mathrm{TY} /(+, 0,0), \\
\mathrm{DI} / \leq 0,0\end{array}$ & $\begin{array}{c}\text { Сектор V. } \\
\mathrm{TR} /(-)<\mathrm{TY} /(-), \\
\mathrm{DI} />0\end{array}$ \\
\hline & & $\begin{array}{c}\text { Сектор III. } \\
\mathrm{TR} /(-; 0,0)>\mathrm{TY} /(-; 0,0), \\
\mathrm{DI} / \leq 0,0\end{array}$ & $\begin{array}{c}\text { Сектор VI. } \\
\mathrm{TR} /(+)>\mathrm{TY} /(-), \\
\mathrm{DI} />0\end{array}$ \\
\hline 4 & $\begin{array}{l}\text { Расчет рейтинга } \\
\text { «эколого- } \\
\text { экономической } \\
\text { привлекатель- } \\
\text { ности» региона }\end{array}$ & \multicolumn{2}{|c|}{$\begin{array}{l}\text { Reea }=? \mathrm{r}_{\mathrm{i}} * \mathrm{f}_{\mathrm{i}} / ? \mathrm{f}_{\mathrm{i}}, \\
\text { где Reеa - рейтинг эколого-экономической при- } \\
\text { влекательности региона; Reea }=[1 \div 6] ; \mathrm{r}_{\mathrm{i}}-\text { номер } \\
\text { сектора декаплинг-анализа, } \mathrm{r}_{\mathrm{i}}=[1,2, \ldots 6] ; \mathrm{f}_{\mathrm{i}}-\text { но- } \\
\text { мер анализируемого периода, } \mathrm{f}_{\mathrm{i}}=[1,2, \ldots \mathrm{n}] ; \mathrm{n}- \\
\text { количество анализируемых периодов }\end{array}$} \\
\hline
\end{tabular}

Примечание. Источник: авторская модель. 
Адаптация методике углубленного декаплинг-анализа на примере российских регионов:

1. Исходные данные: в качестве исходных данных использовались данные Росстата по регионам ${ }^{43}$ :

- выбросы загрязняющих веществ от стационарных источников, тыс. тонн;

- сброс загрязненных сточных вод в поверхностные водные объекты, млн куб.м.;

- индексы физического объема валового регионального продукта;

- индексы физического объема валового регионального продукта на душу населения;

- численность населения, тыс. чел.;

Данные по численности населения представлены за период 2010 2017 гг., данные по выбросам загрязняющих веществ от стационарных источников доступны с 2002 по 2017 гг., индексы физического объема ВРП - с 1998 по 2016 гг., индексы физического объема ВРП на душу населения - с 2005 по 2016 гг, сброс загрязненных сточных вод в поверхностные водные объекты - данные территориальных органов ФСГС ${ }^{44}$ за разные периоды - от отсутствия данных (пример: Республика Адыгея, Астраханская область), до данных с 2005 по 2016 гг. (например, по Волгоградской, Вологодской областям и др.).

2. Расчет индексов декаплинга. Авторами был проведен анализ и рассчитаны индексы декаплинга по российским регионам:

Вариант 1: по классической модели декаплинга (формула 7) по данным роста выбросов загрязняющих веществ от стационарных источников, сброса загрязненных сточных вод в поверхностные водные объекты и значений индексов физического объема валового регионального продукта.

Вариант 2: по классической модели декаплинга (формула 7) по данным роста показателей в расчете на душу населения.

43 Единая межведомственная информационно-статистическая база // https:/ /fedstat.ru/.

${ }^{44}$ Сайты ТОГС // http://www.gks.ru/wps/wcm/connect/rosstat_main/rosstat/ ru/about/territorial/site/. 
Вариант 3: по модели углубленного декаплиг-анализа (формула 8) по данным прироста выбросов загрязняющих веществ от стационарных источников, сброса загрязненных сточных вод в поверхностные водные объекты и значений индексов физического объема валового регионального продукта. Результаты расчетов не противоречат варианту 1.

Вариант 4. По модели углубленного декаплиг-анализа (формула 8) по данным прироста показателей на душу населения. Результаты расчетов не противоречат варианту 2 .

Результаты расчетов вариантов 1 и 2 , а также 3 и 4 в основном совпадают. Если расхождения наблюдаются, то это происходит в 1 из 6 анализируемых периодов, что вызвано округлением данных, разницей в исходных данных. Для анализа были использованы данные за периоды: 1 и 2 варианты - 2005-2016 гг; 3 и 4 варианты - 2010-2016 гг.

Специалисты ${ }^{45}$ рекомендуют использовать при расчетах данные на душу населения, что отвечает методологическим и концептуальным характеристикам анализируемых показателей: прогресс экологического и экономического развития необходимо соотносить с отдельным индивидуумом. Исходя из данных аргументов, для итоговых выводов был принят расчет по данным на душу населения, проведенный по методике углубленного декаплинг-анализа.

Декаплинг-анализ может проводиться на основе базисных показателей, по отношению к выбранному году отсчета, и на основе цепных показателей в динамике за ряд периодов. При анализе по базисным показателям возникает необходимость в обосно-

45 Думнов А.Д., Борискин Д.А., Рыбальский Н.Г. О некоторых методах макростатистического анализа природопользования и охраны окружающей среды // Век глобализации. - 2017 - № 2. - С. 37-50; Эколого-экономический индекс регионов РФ. Методика и показатели для расчета / С. Н. Бобылев, В. С. Минаков и др. - М.: WWF России, РИА Новости, 2012. - 152 с. // https://wwf.ru/upload/ iblock/dc8/index.pdf; The World Only.От понимания к устойчивому развитию. News of the age of sustainable development // https://theworldonly.org/indekschelovecheskogo-razvitiya-po-stranam/, Индексы и индикаторы человеческого развития: Обновленные статистические данные 2018. Программа развития Организации Объединенных Наций (ПРООН), 2018. - 122 с. 
вании базисных значений показателей или базисного периода, по отношению к которым ведется расчет. Такой подход целесообразен и широко используется, учитывая инерционность производственных и экономических процессов.

В тоже время считаем возможным использование в декаплинг-анализе и цепных показателей, что позволяет проводить сравнение в региональном разрезе, давать оценку усилий регионов по достижению целей устойчивого развития. Выбор способа расчета будет определяться целями анализа. В исследовании проведен декаплинг-анализ по отношению к 2010 г. и в динамике за 20102016 гг. Для анализа были использованы показатели в расчете на душу населения.

3. Определение сектора в модели оценки эффекта декаплинга и его характеристика. На основе рассчитанных показателей TR/ иTY/, проводится их сравнение и определяется сектор в модели декаплинг-анализа, дается его характеристика.

4. Расчет рейтинга «эколого-экономической привлекательности» региона. Используя данные о значении сектора декаплинг-анализа рассчитывается рейтинг (формула 9), который считаем возможным применить для характеристики региональных рисков инвестирования в экологические проекты

Авторами проведено исследование 80 российских регионов по предложенной методике декаплинг-анализа. Данные анализа во всем анализируемым регионам представлены в приложениях А, Б, обобщенные результаты - в таблицах $14,15$.

Таблицча 14

Структура регионов по секторам методики декаплинг-анализа за период 2011-2016 гг.

\begin{tabular}{|c|c|c|c|c|c|c|c|c|c|c|c|c|}
\hline & \multicolumn{2}{|c|}{2011} & \multicolumn{2}{|c|}{2012} & \multicolumn{2}{|c|}{2013} & \multicolumn{2}{|c|}{2014} & \multicolumn{2}{|c|}{2015} & \multicolumn{2}{|c|}{2016} \\
\hline & $\mathrm{g}$ & $\%$ & $\mathrm{~g}$ & $\%$ & $\mathrm{~g}$ & $\%$ & $\mathrm{~g}$ & $\%$ & $\mathrm{~g}$ & $\%$ & $\mathrm{~g}$ & $\%$ \\
\hline Вариант 1 & & & & & & & & & & & & \\
\hline 1 & 39 & 48,75 & 34 & 42,50 & 38 & 47,50 & 43 & 53,75 & 45 & 56,25 & 40 & 50,00 \\
\hline 2 & 21 & 26,25 & 24 & 30,00 & 20 & 25,00 & 10 & 12,50 & 13 & 16,25 & 14 & 17,50 \\
\hline 3 & 0 & 0,00 & 2 & 2,50 & 2 & 2,50 & 5 & 6,25 & 5 & 6,25 & 5 & 6,25 \\
\hline Всего 1-3 & & 75,00 & & 75,00 & & 75,00 & & 72,50 & & 78,75 & & 73,75 \\
\hline
\end{tabular}


Окончание таблицы 14

\begin{tabular}{|c|c|c|c|c|c|c|c|c|c|c|c|c|}
\hline & $\mathbf{2 0 1 1}$ & \multicolumn{2}{|c|}{$\mathbf{2 0 1 2}$} & \multicolumn{2}{c|}{$\mathbf{2 0 1 3}$} & \multicolumn{2}{|c|}{$\mathbf{2 0 1 4}$} & \multicolumn{2}{|c|}{$\mathbf{2 0 1 5}$} & \multicolumn{2}{|c|}{$\mathbf{2 0 1 6}$} \\
\hline & $\mathbf{g}$ & $\mathbf{\%}$ & $\mathbf{g}$ & $\mathbf{\%}$ & $\mathbf{g}$ & $\mathbf{\%}$ & $\mathbf{g}$ & $\mathbf{\%}$ & $\mathbf{g}$ & $\mathbf{\%}$ & $\mathbf{g}$ & $\mathbf{\%}$ \\
\hline $\mathbf{4}$ & 19 & 23,75 & 18 & 22,50 & 16 & 20,00 & 21 & 26,25 & 16 & 20,00 & 19 & 23,75 \\
\hline $\mathbf{5}$ & 0 & 0,00 & 1 & 1,25 & 1 & 1,25 & 0 & 0,00 & 1 & 1,25 & 2 & 2,50 \\
\hline $\mathbf{6}$ & 1 & 1,25 & 1 & 1,25 & 3 & 3,75 & 1 & 1,25 & 0 & 0,00 & 0 & 0,00 \\
\hline Всего 4-6 & & 25,00 & & 25,00 & & 25,00 & & 27,50 & & 21,25 & & 26,25 \\
\hline Итого: & 80 & 100,00 & 80 & 100,00 & 80 & 100,00 & 80 & 100,00 & 80 & 100,00 & 80 & 100,00 \\
\hline Вариант 2 \\
\hline $\mathbf{1 0}$ \\
\hline $\mathbf{1}$ & 39 & 48,75 & 26 & 32,50 & 36 & 45,00 & 37 & 46,25 & 16 & 20,00 & 22 & 27,50 \\
\hline $\mathbf{2}$ & 21 & 26,25 & 19 & 23,75 & 7 & 8,75 & 3 & 3,75 & 3 & 3,75 & 3 & 3,75 \\
\hline $\mathbf{3}$ & 0 & 0,00 & 5 & 6,25 & 6 & 7,50 & 11 & 13,75 & 23 & 28,75 & 8 & 10,00 \\
\hline Всего 1-3 & & 75,00 & & 62,50 & & 61,25 & & 75,00 & & 52,50 & & 41,25 \\
\hline $\mathbf{4}$ & 19 & 23,75 & 26 & 32,50 & 20 & 25,00 & 23 & 28,75 & 16 & 20,00 & 27 & 33,75 \\
\hline $\mathbf{5}$ & 0 & 0,00 & 2 & 2,50 & 2 & 2,50 & 1 & 1,25 & 3 & 3,75 & 2 & 2,50 \\
\hline $\mathbf{6}$ & 1 & 1,25 & 2 & 2,50 & 9 & 11,25 & 5 & 6,25 & 19 & 23,75 & 18 & 22,50 \\
\hline Всего 4-6 & & 25,00 & & 37,50 & 0 & 38,75 & & 36,25 & & 47,50 & & 58,75 \\
\hline Итого: & 80 & 100,00 & 80 & 100,00 & 80 & 100,00 & 80 & 100,00 & 80 & 100,00 & 80 & 100,00 \\
\hline
\end{tabular}

Примечание: $\mathrm{g}$ - количество регионов в секторе модели декаплинг-анализа; \% - процент регионов в секторе модели декаплинг-анализа.

Источник: расчеты авторов.

Выводы. Анализ позволяет сделать следующие выводы: по сравнению с 2010 г. наблюдается устойчивый эффект декаплинга в российских регионах: количество регионов с эффектом декаплинга колеблется около 75 \% за анализируемый период, при этом число регионов с абсолютным эффектом декаплинга составляет в среднем 40, то есть практически $50 \%$ российских регионов. Из оставшихся регионов около половины (в среднем 18 регионов) находятся в секторе «бурого роста», то есть наблюдается экономический рост, но при большей нагрузке на окружающую среду. Но, если изменить подход к выбору точки отсчета (базисного периода) и рассмотреть изменение цепных показателей, что предполагает анализ стремления к достижению ежегодной эффективности, то увидим негативные тенденции. Так за анализируемый период (шесть лет) имеется тенденция к ухудшению эколого-экономическое состояния российских регионов в последние два года $(2015,2016)$. Так, в 2011 году в 75,00 \% регионов наблюдался эффект декаплинга, при этом 
в 48,75 \% наблюдался абсолютный эффект декаплинга - наилучшая ситуация, которая характеризуется экономическим ростом при снижении антропогенной нагрузки на окружающую среду. В следующие периоды наблюдалось тенденция к снижению числа регионов, имеющих эффект декаплинга: 2012 год количество регионов с эффектом декаплинга составило 62,50\%, в 2013 г. - 61,25\%, в 2014 г. - 75,00\%, далее наблюдается резкий спад: в 2015 г. - 52,50 \%, в 2016 - 41,25 \%. При этом снижалось «качество» эфффекта декаплинга: количество регионов с абсолютным эффектом декаплинга уменьшилось в 1,77 раза (с $48,75 \%$ до $27,5 \%$ ).

Увеличилось число регионов, эколого-экономическое состояние которых можно охарактеризовать как «бурый» рост. Так, в 2011 г. «бурый» рост был характерен для 19 регионов $(23,75 \%)$, в 2012 г. для 26 регионов $(32,5 \%)$, в 2013 - для 20 регионов $(25,00 \%)$; в 2014 г. - для 23 региона $(28,75 \%)$; в 2015 г. - для 16 регионов (20,00\%); в 2016 г. - для 27 регионов (33,75\%).

Что касается наихудшей ситуации в декаплинг модели, а именно снижения экономических показателей при увеличении антропогенной нагрузки на окружающую среду, то можно отметить, что на протяжении исследуемого периода отчетливо видна отрицательная динамика: в 2011 г. только для одного региона была характерна такая ситуация, в 2012 г. - для двух регионов, в 2013 г. - уже для девяти, в 2014 г. - пять регионов оказались в данном секторе, в 2015 г. 19 (23,75 \%) и 2016 г. 18 регионов $(22,5 \%)$.

Можно сделать вывод, что сложная экономическая ситуация для российской экономики в 2015-2016 гг. негативно отразилась не только на благополучии населения, но и привела к ухудшению окружающей среды, при этом по сравнению с 2010 г. ситуация остается стабильной Такая ситуация ожидаема, поскольку экономические процессы характеризуются инерционностью в своем развитии. Это позволяет прийти к заключению о необходимости исследования эколого-экономических процессов в динамике и учете фаз экономического цикла, подводя итоги эффективности эколого-экономической политики регионов. 
Таблица 15

\section{Структура регионов по секторам декаплинг-анализа}

\begin{tabular}{|c|c|c|c|}
\hline Сектор & Регионы & $\mathrm{g}$ & $\%$ \\
\hline \multicolumn{4}{|c|}{2016} \\
\hline 1 & $\begin{array}{l}\text { Белгородская область, Владимирская область, Воро- } \\
\text { нежская область, Костромская область, Курская об- } \\
\text { ласть, Липецкая область, Орловская область, Рязан- } \\
\text { ская область, Тульская область, Архангельская об- } \\
\text { ласть, Вологодская область, Калининградкая об- } \\
\text { ласть, Мурманская область, Волгоградская область, } \\
\text { Республика Калмыкия, Ростовская область, Респуб- } \\
\text { лика Дагестан, Карачаево-Черкесская Республика, } \\
\text { Республика Северная Осетия-Алания, Чеченская Рес- } \\
\text { публика, Чувашская республика, Пермский край, } \\
\text { Нижегородская область, Оренбургская область, Са- } \\
\text { марская область, Ульяновская область, Курганская } \\
\text { область, Свердловская область, Челябинская область, } \\
\text { Республика Тыва, Республика Хакасия, Забайкаль- } \\
\text { ский край, Красноярский край, Новосибирская об- } \\
\text { ласть, Омская область, Томская область, Камчатский } \\
\text { край, Хабаровский край, Сахалинская область, Чу- } \\
\text { котский автономный округ }\end{array}$ & 40 & 50,00 \\
\hline 2 & $\begin{array}{l}\text { Брянская область, Тамбовская область, Тверская об- } \\
\text { ласть, Ярославская область, Республика Коми, Ле- } \\
\text { нинградская область, Новгородская область, Астра- } \\
\text { ханская область, Республика Марий Эл, Республика } \\
\text { Мордовия, Кировская область, Саратовская область, } \\
\text { Алтайский край, Иркутская область }\end{array}$ & 14 & 17,50 \\
\hline 3 & $\begin{array}{l}\text { Ивановская область, г. Москва, Тюменская область, } \\
\text { Приморский Край, Еврейская автономная область }\end{array}$ & 5 & 6,25 \\
\hline 4 & $\begin{array}{l}\text { Калужская область, Московская область, Смоленская } \\
\text { область, Республика Карелия, Псковская область, } \\
\text { Санкт-Петербург, Республика Адыгея, Краснодар- } \\
\text { ский край, Республика Ингушетия, Кабардино- } \\
\text { Балкарская Республика, Ставропольский край, Рес- } \\
\text { публика Башкортостан, Республика Татарстан, Уд- } \\
\text { муртская республика, Пензенская область, Республи- } \\
\text { ка Алтай, Республика Саха (Якутия), Амурская об- } \\
\text { ласть, Магаданская область }\end{array}$ & 19 & 23,75 \\
\hline 5 & Республика Бурятии, Кемеровская область & 2 & 2,50 \\
\hline 6 & - & 0 & 0,00 \\
\hline
\end{tabular}


Окончание таблицы 15

\begin{tabular}{|c|c|c|c|}
\hline Сектор & Регионы & $\mathbf{g}$ & $\%$ \\
\hline \multicolumn{4}{|c|}{2011} \\
\hline 1 & $\begin{array}{l}\text { Воронежская область, Костромская область, Липец- } \\
\text { кая область, Московская область, Рязанская область, } \\
\text { Ярославская область, г. Москва, Республика Карелия, } \\
\text { Архангельская область, Вологодская область, Кали- } \\
\text { нинградская область, Ленинградская область, Мур- } \\
\text { манская область, Новгородская область, Волгоград- } \\
\text { ская область, Ростовская область, Республика Даге- } \\
\text { стан, Республика Ингушетия, Кабардино-Балкарская } \\
\text { Республика, Республика Северная Осетия-Алания, } \\
\text { Чеченская Республика, Республика Марий Эл, Чу- } \\
\text { вашская республика, Кировская область, Нижегород- } \\
\text { ская область, Самарская область, Курганская область, } \\
\text { Свердловская область, Челябинская область, Респуб- } \\
\text { лика Бурятии, Республика Тыва, Республика Хакасия, } \\
\text { Алтайский край, Забайкальский край, Кемеровская } \\
\text { область, Республика Саха (Якутия), Камчатский край, } \\
\text { Хабаровский край, Сахалинская область }\end{array}$ & 39 & 48,75 \\
\hline 2 & $\begin{array}{l}\text { Белгородская область, Брянская область, Владимир- } \\
\text { ская область, Ивановская область, Калужская об- } \\
\text { ласть, Курская область, Орловская область, Смолен- } \\
\text { ская область, Тамбовская область, Астраханская об- } \\
\text { ласть, Республика Калмыкия, Ставропольский край, } \\
\text { Республика Башкортостан, Республика Мордовия, } \\
\text { Удмуртская республика, Красноярский край, Иркут- } \\
\text { ская область, Новосибирская область, Омская об- } \\
\text { ласть, Приморский Край, Магаданская область }\end{array}$ & 21 & 26,25 \\
\hline 3 & - & 0 & 0,00 \\
\hline 4 & $\begin{array}{l}\text { Тверская область, Тульская область, Республика Ко- } \\
\text { ми, Псковская область, Санкт-Петербург, Республика } \\
\text { Адыгея, Краснодарский край, Карачаево-Черкесская } \\
\text { Республика, Республика Татарстан, Пермский край, } \\
\text { Оренбургская область, Пензенская область, Саратов- } \\
\text { ская область, Ульяновская область, Тюменская об- } \\
\text { ласть, Республика Алтай, Томская область, Амурская } \\
\text { область, Еврейская автономная область }\end{array}$ & 19 & 23,75 \\
\hline 5 & - & 0 & 0,00 \\
\hline 6 & Чукотский автономный округ & 1 & 1,25 \\
\hline
\end{tabular}

Примечание: в расчетах использовались базисные индексы, 2010 г. - базисный.

Источник: расчеты авторов. 
Сравнивая состав регионов по секторам модели декаплинганализа в 2011 и в 2016 гг. (таблица 15) можно сделать вывод о высокой вариативности: абсолютный эффект декаплинга (1 сектор) сохранили $61,5 \%$ регионов, то есть $38,5 \%$ ухудшили свое эколого-эконгомическое состояние. Еще большие изменения в составе регионов произошли в остальных секторах: во втором секторе осталось 23,8 \% в 2016 г. по сравнению с 2011 г., в 4 секторе («бурый» рост) характерен для 42,1 \% (8 из 19 регионов), Чукотский автономный округ поднялся из 6 сектора в 5 .

Выводы: Эффективность экономики в настоящее время неотъемлема без учета влияния деятельности человека на окружающую среду. Противоречия экономических и экологических интересов приводят планету к глобальному экологическому кризису. Возросшая значимость экологических проблем диктует необходимость соблюдения принципов устойчивого развития и перехода к «зеленой» экономике. Устойчивый экономический рост должен обеспечиваться за счет воссоздания и развития «зеленой» инфраструктуры и повышения качества жизни населения. К настоящему времени российская экономика не достигла декаплинга - эффекта, при котором экономический рост сопровождается снижением выбросов. Экономические кризисы, наблюдаемые в последнее время, в первую очередь привлекают внимание к политическим, социальным, экологическим проблемам, перенося вектор внимания с экологических проблем. Поиск российским регионами новых стратегий неразрывно связан с поддержкой и стимулированием эколого-экономического развития, с вниманием к сфере природопользования. Формирование и реализация стратегий экологоэкономического развития регионами требует разработки методов количественной оценки негативного влияния антропогенного воздействия на окружающую среду при сопоставлении с экономическим развитием. В исследовании авторами предложена модель углубленного декаплинг-анализа, позволяющая не только оценить наличие или отсутствие эффекта декаплинга, но и выделить шесть секторов, характеризующих различную степень эффективности эколого-экономического состояния ре- 
гионов. Авторами проведена апробация модели на примере 80 российских регионов, полученные результаты позволяют сделать вывод о наличии эффекта декаплинга в сравнении с 2010 г., но экономические кризисы оказали существенное негативное влияние как на экономическую, так и на экологическую динамику многих российских регионов.

\section{4. Эффект декаплинга: особенности регионов ЮФО}

Более подробно рассмотрены регионы Южного Федерального округа Результаты анализа регионов ЮФО представлены в таблице 16. Анализ и оценка эколого-экономического состояния российских регионов проведена по авторской методике углубленного декаплинг-анализа.

Рассмотрим результаты анализа для регионов ЮФО. В состав Южного Федерального округа входят следующие субъекты Российской Федерации: Республика Адыгея, Астраханская область, Волгоградская область, Республика Калмыкия, Краснодарский край, Ростовская область, Республика Крым, город Севастополь. Республика Крым и город Севастополь вошли в состав Южного Федерального округа в 2016 г., статистические данные за длинный период по ним отсутствуют, поэтому данные субъекты были исключены из анализа.

Таблицуа 16

\section{Характеристика эффекта декаплинга (на примере регионов ЮФО)}

\begin{tabular}{|c|c|c|c|c|c|c|}
\hline Показатели & 2011 & 2012 & 2013 & 2014 & 2015 & 2016 \\
\hline \multicolumn{7}{|c|}{ Республика Адыгея, Reea $=4,00$, Reea $^{\prime}=4,00$} \\
\hline R, отн. ед. & 1,175 & 1,473 & 1,360 & 1,175 & 1,045 & 1,021 \\
\hline ТY, отн. ед & 1,053 & 1,054 & 1,023 & 1,033 & 1,002 & 1,014 \\
\hline $\mathrm{R}_{б}$, отн. ед. & 1,175 & 1,731 & 2,353 & 2,766 & 2,891 & 2,951 \\
\hline $\mathrm{TY}_{б}$, отн. ед. & 1,053 & 1,110 & 1,135 & 1,173 & 1,175 & 1,192 \\
\hline Сектор по $R$ & 4 & 4 & 4 & 4 & 4 & 4 \\
\hline Сектор по $R$ & 4 & 4 & 4 & 4 & 4 & 4 \\
\hline
\end{tabular}


Окончание таблицы 16

\begin{tabular}{|c|c|c|c|c|c|c|}
\hline Показатели & 2011 & 2012 & 2013 & 2014 & 2015 & 2016 \\
\hline \multicolumn{7}{|c|}{ Астраханская область, Reea $=3,19$, Reea $^{\prime}=1,67$} \\
\hline R, отн. ед. & 1,054 & 1,017 & 0,972 & 0,903 & 1,000 & 1,071 \\
\hline ТY, отн. ед & 1,076 & 1,111 & 1,161 & 1,001 & 0,990 & 1,029 \\
\hline $\mathrm{R}_{б}$, отн. ед. & 1,054 & 1,071 & 1,041 & 0,940 & 0,940 & 1,007 \\
\hline $\mathrm{TY}_{б}$, отн. ед. & 1,076 & 1,195 & 1,388 & 1,389 & 1,375 & 1,415 \\
\hline Сектор по $R$ & 2 & 2 & 1 & 1 & 6 & 4 \\
\hline Сектор по $R$ & 2 & 2 & 2 & 1 & 1 & 2 \\
\hline \multicolumn{7}{|c|}{ Волгоградская область, Reea $=3,76, \mathrm{Reea}^{\prime}=1,00$} \\
\hline R, отн. ед. & 0,889 & 0,963 & 1,016 & 0,893 & 1,047 & 1,014 \\
\hline ТY, отн. ед & 1,037 & 1,033 & 1,019 & 1,052 & 0,943 & 0,990 \\
\hline $\mathrm{R}_{\text {б, отн. ед. }}$ & 0,889 & 0,856 & 0,869 & 0,777 & 0,813 & 0,824 \\
\hline ТY $_{б}$, отн. ед. & 1,037 & 1,071 & 1,092 & 1,148 & 1,083 & 1,072 \\
\hline Сектор по $R$ & 1 & 1 & 2 & 1 & 6 & 6 \\
\hline Сектор по $R$ & 1 & 1 & 1 & 1 & 1 & 1 \\
\hline \multicolumn{7}{|c|}{ Республика Калмыкия, Reea $=2,81$, Reea $^{\prime}=2,83$} \\
\hline R, отн. ед. & 1,024 & 1,032 & 1,853 & 0,681 & 0,756 & 0,645 \\
\hline $\mathrm{TY}, \mathrm{O}$ & 1,027 & 1,008 & 1,034 & 1,053 & 0,965 & 0,986 \\
\hline $\mathrm{R}_{6}, \mathrm{OTH}$ & 1,024 & 1,057 & 1,958 & 1,334 & 1,008 & 0,650 \\
\hline TY $_{\sigma}$, отн. ед. & 1,027 & 1,035 & 1,070 & 1,127 & 1,088 & 1,072 \\
\hline Сектор по $R$ & 2 & 4 & 4 & 1 & 3 & 3 \\
\hline Сектор по $R$ & 2 & 4 & 4 & 4 & 2 & 1 \\
\hline \multicolumn{7}{|c|}{ Краснодарский край, Reea $=4,43$, Reea $=4,00$} \\
\hline R, отн. ед. & 1,157 & 1,324 & 0,943 & 0,908 & 1,001 & 1,256 \\
\hline ТY, отн. ед & 1,069 & 1,027 & 1,028 & 0,996 & 0,974 & 0,990 \\
\hline $\mathrm{R}_{6}$, отн. ед. & 1,157 & 1,532 & 1,444 & 1,311 & 1,313 & 1,648 \\
\hline ТYб, отн. ед. & 1,069 & 1,098 & 1,129 & 1,124 & 1,095 & 1,084 \\
\hline Сектор по $R$ & 4 & 4 & 1 & 3 & 6 & 6 \\
\hline Сектор по $R^{\prime}$ & 4 & 4 & 4 & 4 & 4 & 4 \\
\hline \multicolumn{7}{|c|}{ Ростовская область, Reea $=2,62$, Reea $^{\prime}=1,50$} \\
\hline R, отн. ед. & 0,878 & 1,305 & 0,964 & 1,009 & 0,851 & 1,027 \\
\hline ТY, отн. ед & 1,076 & 1,111 & 1,161 & 1,001 & 0,990 & 1,029 \\
\hline $\mathrm{R}_{б}$, отн. ед. & 0,878 & 1,145 & 1,103 & 1,114 & 0,947 & 0,973 \\
\hline ТY & 1,076 & 1,195 & 1,388 & 1,389 & 1,375 & 1,415 \\
\hline Сектор по $R$ & 1 & 4 & 1 & 4 & 3 & 2 \\
\hline Сектор по $R$ & 1 & 2 & 2 & 2 & 1 & 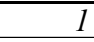 \\
\hline
\end{tabular}

Примечание. $\mathrm{R}$ - индекс роста загрязняющих веществ от стационарных источников, отн. ед.; $\mathrm{R}_{6}$ - индекс роста загрязняющих веществ от стационарных источников, отн. ед. базисные индексы; ТY - индекс физического объема ВРП, отн. ед.; ТY - индекс физического объема ВРП, отн. ед., базисные индексы; сектор по $\mathrm{R}, \mathrm{R}^{\prime}$ - сектор, характеризующий эффект декаплинга по модели декаплинг-анализа; Reea, Reea' - рейтинг эколого-экономической привлекательности региона.

Источник: рассчитано авторами по сайты ТОГС // http:/www.gks.ru/wps/ wcm/connect/rosstat_main/rosstat/ru/about/territorial/site/; Единая межведомственная информационно-статистическая база, // Сайт Росстата // https://fedstat.ru/. 
Выводы. На основе проведенного анализа можно говорить о наличие эффекта декаплинга в большинстве анализируемых периодов по всем регионам Южного Федерального округа. Анализ по модели углубленного декаплинг-анализа позволил уточнить данные традиционного показателя декаплинга и проранжировать регионы по степени эколого-экономической привлекательности. Проведенное исследование позволило выявить следующие особенности эколого-экономического состояния регионов ЮФО:

Во-1-х, анализируя эффект декаплинга в сравнении с 2010 г. отметим улучшение эколого-экономического состояния в четырех регионах ЮФО из шести. Только в Республике Адыгея и Краснодарском крае наблюдается «бурый» экономический рост (сектор 4), сопровождающийся ростом антропогенной нагрузки на окружающую среду. В Волгоградской, Ростовской областях и Республике Калмыкия наблюдается абсолютный эффект декаплинга, в Астраханской области - относительный.

Во-2-х, результаты по годам анализируемого периода демонстрируют более сложную динамику:

- в Ростовской области эффект декаплинга наблюдается в $67 \%$ наблюдений, в т.ч. абсолютный эффект - в $33 \%$, отсутствие эффекта декаплинга в 33 \% сопровождается «бурым» экономическим ростом, при котором темпы загрязнения окружающей среды выше темпов экономического роста;

- Астраханская область характеризуется следующими показателями: эффект декаплинга присутствует в 67 \% случаев, абсолютный эффект декаплинга - 33 \%. Периоды отсутствия эффекта декаплинга характеризуются «бурым экономическим ростом» и наихудшей ситуацией - отсутствие экономического роста в регионе при одновременном увеличении вредных выбросов в окружающую среду; в 2015 и 2016 гг. эффект декаплинга отсутствовал.

- анализ данных по Республике Калмыкия показывает наличие эффекта декаплинга в 67 \% наблюдений, при этом два периода наблюдений (33 \%) характеризуются, «бурым» экономическим ростом, который сопровождается ухудшением экологической ситуации в регионе (4 сектор модели декаплинг-анализа); 
- Краснодарский край показал наличие эффекта декаплинга только в 33,3 \% из анализируемых периодов, в 33,3 \% - «бурый» экономический рост, 33,3 \% - наихудшая эколого-экономическая ситуация (6 сектор модели декаплинг-анализа) за последние два года анализа.

- Республика Адыгея характеризуется низкими абсолютными значениями выбросов, но их быстрым ростом (средний темп роста за анализируемый период - 3,025), тогда как Калмыкия, значения выбросов в которой сопоставимы с выбросами по Адыгее, показывает снижение выбросов (средний темп роста - 0,925). Для Республики Адыгея за анализируемый период в 100 \% отмечается «бурый» экономический рост.

- в Волгоградской области эффект декаплинга наблюдается в $67 \%$ случаев, абсолютный эффект составляет 50 \%. По наличию абсолютного эффекта декаплинга Волгоградская область превышает показатели других регионов ЮФО. Но в 2015, 2016 гг. характеризуются отсутствием эффекта декаплинга, прослеживается снижение темпа прироста физического объема ВРП на душу населения при росте нагрузки на окружающую среду - наихудшая ситуация (сектор 6 модели декаплинг-анализа), поэтому имеет место невысокий рейтинг «эколого-экономического риска» региона по сравнению с другими регионами ЮФО.

\section{5. Оценка эколого-экономического состояния Волгоградской области}

Волгоградская область активно участвует в реализации государственных программ в сфере экологии. В 2018 г. в области реализовывалась государственная программа Волгоградской области «Охрана окружающей среды на территории Волгоградской области» в состав которой включены следующие подпрограммы ${ }^{46}$ :

46 Доклад о ходе реализации государственной программы Волгоградской области «Охрана окружающей среды на территории Волгоградской области» за 2018 г. https:/oblkompriroda.volgograd.ru/current-activity/programs/results/https:/ /oblkompriroda.volgograd.ru/upload/iblock/3cc/Doklad-2018.pdf. 
«Сохранение биологического разнообразия и развитие системы особо охраняемых природных территорий»; «Экологическое просвещение»; «Охрана атмосферного воздуха»; «Государственный экологический мониторинг (государственный мониторинг окружающей среды)»; «Обращение с твердыми коммунальными отходами на территории Волгоградской области»; «Развитие охотничьего хозяйства»; «Развитие лесного хозяйства»; «Геологическое изучение недр, воспроизводство минерально-сырьевой базы и рациональное использование недр на территории Волгоградской области». Главной целью реализации государственной программы является обеспечение экологической безопасности Волгоградской области.

В 2019-2021 гг. Волгоградская область получит более 9 млрд руб. на реализацию программ в рамках национального проекта «Экология». Область участвует таких проектах экологической направленности как: «Чистая страна», «Комплексная система обращения с твердыми коммунальными отходами», «Сохранение лесов», «Сохранение уникальных водных объектов», «Оздоровление Волги». На проекты по ликвидации накопленного экологического ущерба и систему обращения с отходами выделяют 1,1 млрд руб. на программу «Оздоровление Волги»- 13 млрд руб., на расчистку ериков и рек, сохранение водных объектов - 9,8 млрд руб. ${ }^{47}$.

В Волгоградской области, по словам главы комитета промышленности и торговли Волгоградской области Р.С. Бекова ${ }^{48}$, предприятия направят на программы улучшения экологической ситуации инвестиции на сумму порядка 30 млрд руб. до 2025 г. 50 промышленных предприятий Волгоградской области реализуют экологические программы. Среди лидеров такие организации как

- ООО «ЛУКОЙЛ-Волгограднефтепереработка» - проект по реконструкции заводского кольца природного и топливного газов;

- ОАО «Волжский абразивный завод» - модернизация оборудования газоочистных установок;

${ }^{47}$ Волгоградской области выделят более 9 млрд руб. на экологию. Шереметьева И. Комсомольская правда-Волгоград, 12.12.2018.

${ }^{48}$ Волгоградские предприятия инвестируют в экологию 30 млрд руб. Н. Глазунова. Комсомольская правда-Волгоград, 16.07.2018. 
- «Себряковцемент» - реконструкция вращающейся печи с переводом на сухой способ производства клинкера ${ }^{49}$;

- Компания «Еврохим-ВолгаКалий» - один из лидеров в области охраны окружающей среды и промышленной безопасности, в 2018 г. компания была награждена золотой медалью за достижения в сфере охраны труда и экологии Международной ассоциации производителей удобрений (IFA) ${ }^{50}$. Ассоциация награждает компании по результатам оценки эффективности деятельности в следующих направлениях: показатели техники безопасности, информированность работников о технике безопасности, экологические показатели, сокращение выбросов $\mathrm{CO}_{2}$.

Не только промышленные компании, государственные органы, но и граждане региона активно участвуют в экологических акциях. В 2018 году в Волгоградской области проведено 1026 эколого-просветительских мероприятий, направленных на формирование экологической культуры населения, в том числе конкурсы, конференции, природоохранные и эколого-просветительские акции, фестивали, в которых принято участие около 40 тыс. чел. ${ }^{51}$.

Рассматривая эколого-экономического состояния и развития Волгоградской области, проведем анализ по следующим показателям: 1) экономические: ВРП в текущих ценах и на душу населения; индекс физического объема ВРП и индекс физического объема ВРП на душу населения; инвестиции в основной капитал, направленные на охрану окружающей среды и рациональное использование природных ресурсов; 2) экологические: выбросы в атмосферу загрязняющих веществ; сброс загрязненных сточных вод; количество утилизированных загрязняющих атмосферу веществ; 3) социальные: численность населения.

${ }^{49}$ Волгоградские предприятия инвестируют в экологию 30 млрд руб. Н. Глазунова. Комсомольская правда-Волгоград, 16.07.2018.

50 «ЕвроХим» награждён золотой медалью за достижения в сфере охраны труда и экологии. Комсомольская правда-Волгоград, 22.11.2018.

51 Доклад о ходе реализации государственной программы Волгоградской области «Охрана окружающей среды на территории Волгоградской области» за 2018 г. https://oblkompriroda.volgograd.ru/current-activity/programs/results/. 


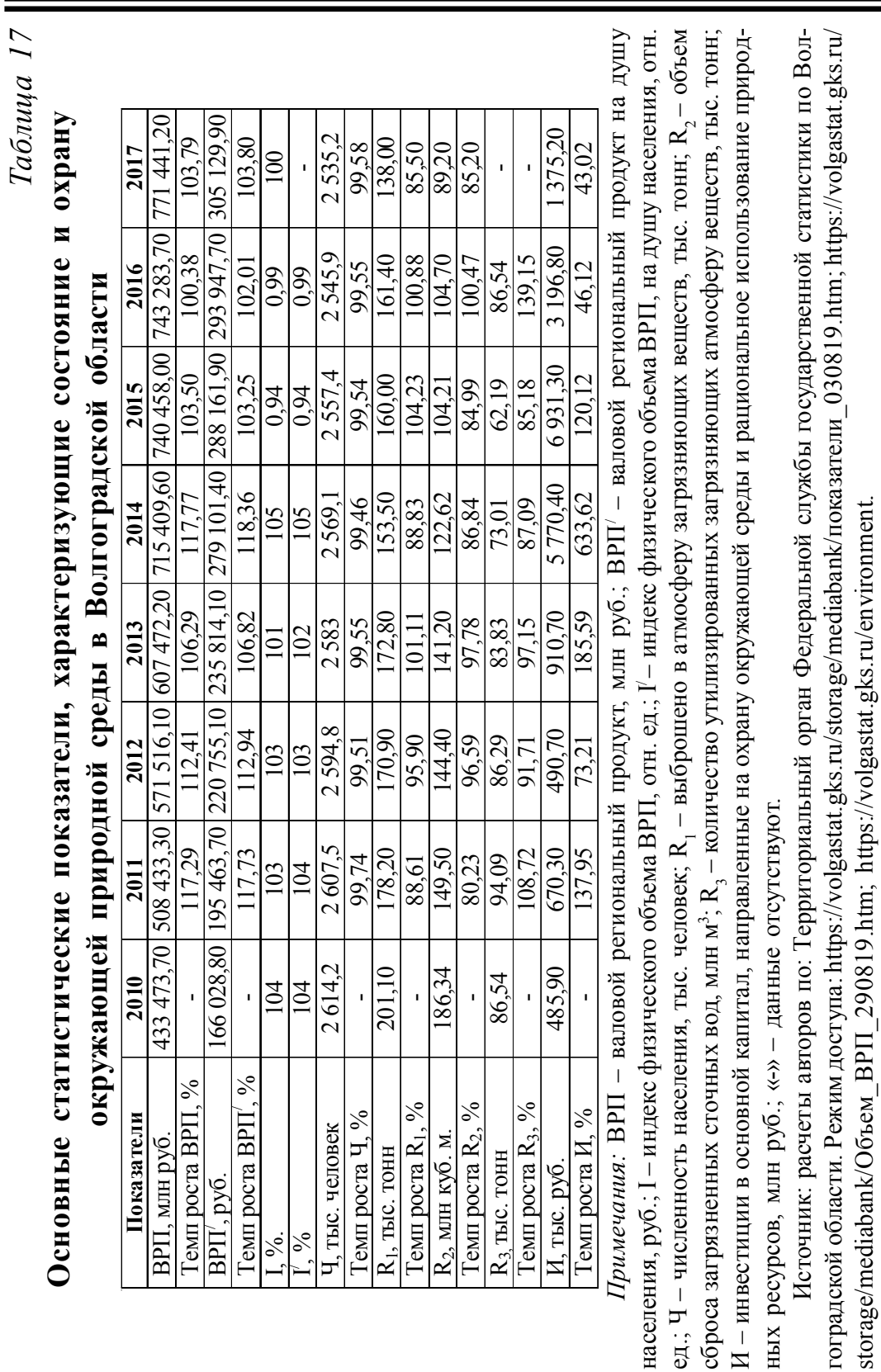


Данные таблицы 17 позволяют выявить следующие тенденции:

- положительные тенденции: рост ВРП в текущих ценах и рост ВРП на душу населения в 2010-1017 гг; значительное снижение объемов сброса загрязненных сточных вод - на 97,14 млн куб. м в 2016 г. по отношению к 2010 г. (52,13\%).

- негативные тенденции: динамика индекса физического объема ВРП, как в целом, так и на душу населения в 2015-2016 гг. носит отрицательный характер (снижение на $6 \%$ в 2015 г. и на $1 \%$ - в 2016 г. по отношению к предыдущему периоду), то есть не наблюдалось реального экономического роста в регионе. Негативной тенденцией является устойчивое снижение численности населения на протяжении всего анализируемого периода. По сравнению с 2010 г. в 2017 г. население Волгоградской области сократилось на 79 тыс. чел. (3,02 \%). Динамика выбросов загрязняющих веществ в атмосферу не показывает устойчивого ежегодного снижения, но по отношению к 2010 г. выбросы сократились на 63,1 тыс. тонн $(31,38$ \%) в 2017 г. При этом отсутствует рост утилизированных загрязняющих атмосферу веществ. Объемы инвестиций в основной капитал, направленный на охрану окружающей среды и рациональное использование природных ресурсов, носят скачкообразный характер и не позволяют сделать уверенного прогноза об их динамике.

Характеризуя экологическую обстановку Волгоградской области, отметим: ввиду наличия на территории гг. Волгограда и Волжского большого количества промышленных предприятий и большого количества автомобильного транспорта большое внимание следует уделять охране атмосферного воздуха. На долю промышленных предприятий региона приходится более 80 \% выбросов загрязняющих веществ в атмосферу. Негативная динамика по количеству выбросов загрязняющих веществ в атмосферу зафиксирована на таких промышленных предприятиях региона, как: ООО «Газпром трансгаз Волгоград», ОАО «Волжский абразивный завод», АО «Каустик», ООО «ЛУКОЙЛ - Волгограднефтепереработка» и др., в связи с увеличением объемов производимой продукции. Положительная динамика наблюдается в ООО «ЛУКОЙЛ - Волгоградэнерго», АО «Волжский Оргсинтез», 
ООО «Экомастер», что объясняется реализацией данными предприятиями природоохранных мероприятий и консервацией производств.

В соответствии с данными полученными на постах государственной наблюдательной сети в атмосферу региона в 2018 году поступили такие загрязняющие вещества, как: пыль, диоксид серы, оксид углерода, диоксид азота, оксид азота, сероводород, фенол, углерод (сажа), фторид водорода, аммиак и др.52. Динамика выбросов представлена в таблице 18 и на рисунке 6 .

Таблицุа 18

\section{Динамика валовых выбросов загрязняющих веществ в атмосферный воздух}

\begin{tabular}{|l|c|c|c|c|c|c|c|c|c|}
\hline \multirow{2}{*}{$\begin{array}{l}\text { Показатели } \\
\text { выбросов }\end{array}$} & $\mathbf{2 0 1 4}$ & \multicolumn{2}{|c|}{$\mathbf{2 0 1 5}$} & \multicolumn{2}{|c|}{$\mathbf{2 0 1 6}$} & \multicolumn{2}{|c|}{$\mathbf{2 0 1 7}$} & \multicolumn{2}{|c|}{$\mathbf{2 0 1 8}$} \\
\cline { 2 - 10 } & тыс. т & тыс. т & $g r$ & тыс. т & $g r$ & тыс. т & $g r$ & тыс. т & $g r$ \\
\hline Всего, т.ч. & 153,5 & 159,9 & 104,17 & 161,4 & 105,15 & 138 & 89,90 & 141,5 & 92,18 \\
\hline твердые & 9,95 & 10 & 100,50 & 8,9 & 89,45 & 8,7 & 87,44 & 6,6 & 66,33 \\
\hline $\begin{array}{l}\text { газообраз- } \\
\text { ные и жид- } \\
\text { кие }\end{array}$ & 143,6 & 149,9 & 104,39 & 152,5 & 106,20 & 129,3 & 90,04 & 134,9 & 93,94 \\
\hline $\begin{array}{l}\text { диоксид } \\
\text { серы }\end{array}$ & 7,2 & 7,6 & 105,56 & 12,1 & 168,06 & 7,4 & 102,78 & 7,5 & 104,17 \\
\hline $\begin{array}{l}\text { оксид угле- } \\
\text { рода }\end{array}$ & 56,7 & 70,8 & 124,87 & 54,5 & 96,12 & 54,3 & 95,77 & 58,1 & 102,47 \\
\hline $\begin{array}{l}\text { оксиды азо- } \\
\text { ты }\end{array}$ & 25,4 & 27,3 & 107,48 & 26,2 & 103,15 & 25,4 & 100,00 & 20,5 & 80,71 \\
\hline $\begin{array}{l}\text { угеводы } \\
\text { (без ЛОС) }\end{array}$ & 28,6 & 28,1 & 98,25 & 39 & 136,36 & 22,7 & 79,37 & 31,4 & 109,79 \\
\hline ЛОС & 22,5 & 23,1 & 102,67 & 17,4 & 77,33 & 17,8 & 79,11 & 16,3 & 72,44 \\
\hline $\begin{array}{l}\text { прочие га- } \\
\text { зообразные } \\
\text { вещества }\end{array}$ & 3,1 & 3,2 & 103,23 & 3,2 & 103,23 & 1,6 & 51,61 & 1,1 & 35,48 \\
\hline
\end{tabular}

Примечание: $\mathrm{gr}$ - темп роста, базисные показатели, \%.

Источник: рассчитано авторами на основе «Доклад о состоянии окружающей среды Волгоградской области в 2018 году» - Ред. Кол.: В.Е. Сазонов [и др.]; комитет природных ресурсов, лесного хозяйства и экологии Волгоградской области. - Ижевск : ООО «Принт», 2019. - 300 с., с. 17.

52 Доклад «О состоянии окружающей среды Волгоградской области в 2018 году» - Ред. Кол.: В.Е. Сазонов [и др.]; комитет природных ресурсов, лесного хозяйства и экологии Волгоградской области. - Ижевск: ООО «Принт», 2019. - 300 c., с. 16. 


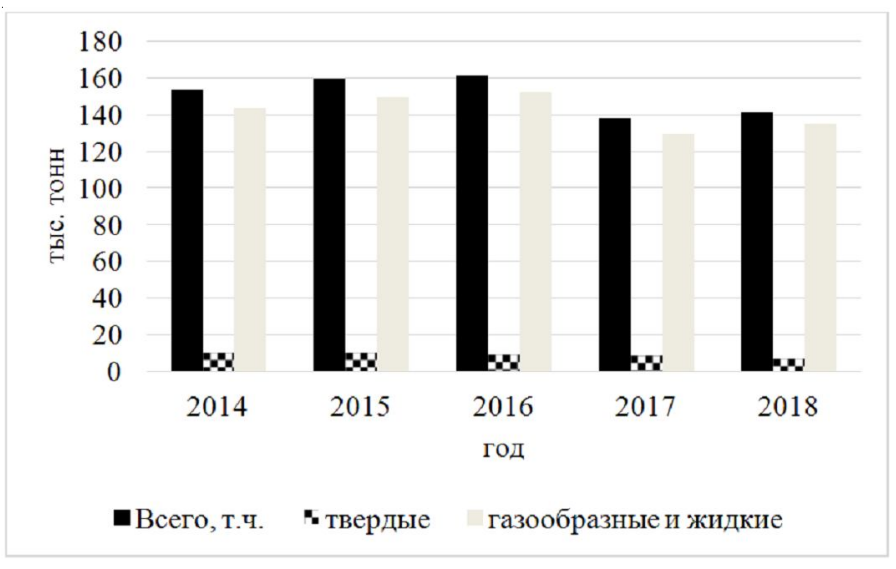

Рис. 6. Динамика валовых выбросов загрязняющих веществ в атмосферный воздух

Примечание. Сост. авторами по: Доклад о состоянии окружающей среды Волгоградской области в 2018 году» - ред. кол.: В.Е. Сазонов [и др.]; комитет природных ресурсов, лесного хозяйства и экологии Волгоградской области. Ижевск: ООО «Принт», 2019. - 300 с., с. 17.

Динамика валовых выбросов загрязняющих веществ в атмосферный воздух Волгоградской области показывает стабильность выбросов: не происходит устойчивого снижения выбросов, но нет и резких изменений в увеличении показателей. Важность снижения выбросов загрязняющих веществ в атмосферу осознана на и международном уровне, и правительством России. В течение года планируется принять Ф3 «О государственном регулировании выбросов и поглощений парниковых газов» ${ }^{53}$. Как отметил вице-премьер А. Гордеев «Россия занимает четвертое место по объему соответствующих выбросов» ${ }^{54}$ и учет влияния экологических вызовов на развитие российской экономики является актуальным.

${ }^{53}$ Проект $Ф 3$ «О государственном регулировании выбросов и поглощений парниковых газов и о внесении изменений в отдельные законодательные акты Российской Федерации»(подготовлен Минэкономразвития России) (не внесен в ГД ФС РФ, текст по состоянию на 27.03.2019) // http://www.consultant.ru/ cons/cgi/online. cgi?req $=$ doc \&base $=$ PRJ\&n $=183113 \# 014268883547042987$.

${ }_{54}^{4}$ РИА Новости // https://ria.ru/20190923/1559005730.html?in=t. 
В связи с этим рассмотрение вопросов оценки эколого-экономического состояния российских регионов приобретает важное значение.

Авторская модель декаплинг-анализа была применена для оценки эколого-экономического состояния Волгоградской области по данным за период 2010-2016 гг. Анализ проведен по отношению к 2010 г. (базовый год) и в динамике за 2010-2016 гг., в исследовании использованы показатели в расчете на душу населения (табл. 19, рис. 7, 8).

Таблица 19

\section{Оценка эколого-экономического состояния \\ Волгоградской области}

\begin{tabular}{|c|c|c|c|c|c|c|c|}
\hline Показатели & 2010 & 2011 & 2012 & 2013 & 2014 & 2015 & 2016 \\
\hline ТY, отн. ед & 1,039 & 1,037 & 1,033 & 1,019 & 1,052 & 0,943 & 0,990 \\
\hline$\triangle$ ТY, отн. ед. & - & 0,0 & 0,0 & & & $-0,057$ & $-0,010$ \\
\hline ТY $^{\prime}$, отн. ед. & & 1,0 & & & & & \\
\hline$\Delta \mathrm{TY}^{\prime}$ & & & & & & 083 & 72 \\
\hline $\mathrm{R}_{1}$, & 01 , & 8. & & 172,8 & & 1 & 161,4 \\
\hline$\Delta \mathrm{R}_{1}$ & -5 &, 111 & $-0,037$ & 0,016 & 0,107 & 0,047 & 0,014 \\
\hline Секи & - & 1 & & 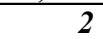 & 1 & 6 & \\
\hline$\Delta \mathrm{R}_{1}^{\prime}$, & & $-0,111$ & $-0,144$ & $-0,131$ & $-0,223$ & $-0,187$ & $-0,176$ \\
\hline Секто & & 1 & 1 & 1 & 1 & 1 & \\
\hline & 6 & 9,50 & 40 & & 22,62 & 04,21 & 104,70 \\
\hline & & 196 &, 030 & 18 & $-0,127$ & $-0,146$ & 0,009 \\
\hline Сек & & - & 1 & $\pi$ & 1 & 3 & 6 \\
\hline$\Delta \mathrm{R}_{2}$ & & $-0,196$ & $-0,219$ & $-0,233$ & $-0,330$ & $-0,428$ & $-0,423$ \\
\hline Сектор по $R_{2}^{\prime}$ & & & 1 & & 1 & & \\
\hline
\end{tabular}

Примечание: ТY - индекс физического объема ВРП , на душу населения, отн. ед.; $\Delta \mathrm{TY}$ - темп прироста физического объема ВРП на душу населения отн. ед.; $\Delta \mathrm{TY}^{\prime}$ - темп прироста физического объема ВРП на душу населения отн. ед., базисные индексы; $\mathrm{R}_{1}$ - выбросы загрязняющих веществ от стационарных источников, тыс. тонн; $\Delta \mathrm{R}_{1}$ - темп прироста $\mathrm{R}_{1}$ на душу населения, отн. ед.; $\Delta \mathrm{R}_{1}^{\prime}-$ темп прироста $\mathrm{R}_{1}$ на душу населения, базисные индексы, отн. ед.; $\mathrm{R}_{2}$ - сброс загрязненных сточных вод в поверхностные водные объекты, млн куб.м; $\Delta \mathrm{R}_{2}-$ темп прироста $\mathrm{R}_{2}$ на душу населения, отн. ед.; $\Delta \mathrm{R}_{2}^{\prime}$ - темп прироста $\mathrm{R}_{2}$ на душу населения, базисные индексы, отн. ед.; сектор (по $\mathrm{R}_{1}, \mathrm{R}_{2}, \mathrm{R}_{1,}^{\prime} \mathrm{R}_{2}^{\prime}$ ) - сектор, характеризующий эффект декаплинга по модели декаплинг-анализа.

Источник: расчеты авторов: Единая межведомственная информационно-статистическая база (ЕМИС). Режим доступа: https://fedstat.ru/, сайты ТОГС. Режим доступа: http://www.gks.ru/wps/wcm/connect/rosstat_main/rosstat/ru/about/territorial/site/. 


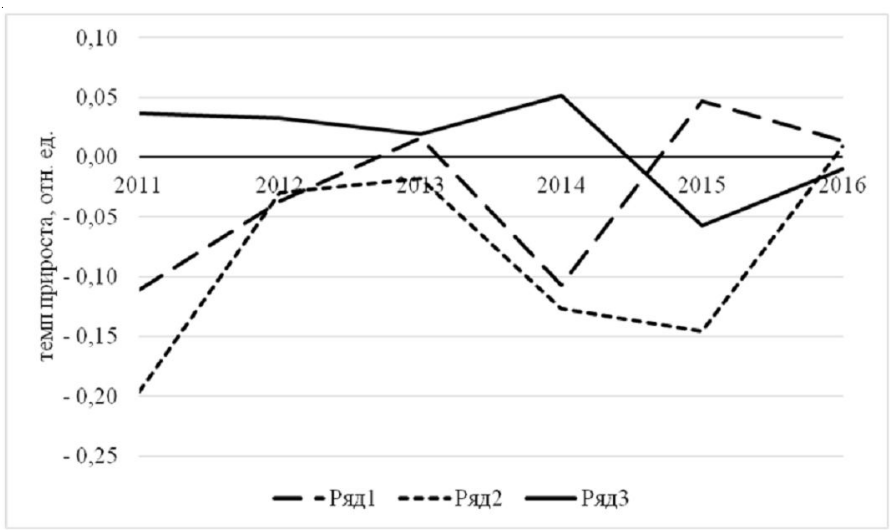

Рис. 7. Эффект декаплинга по Волгоградской области

Примечания: ряд 1 - темп прироста физического объема ВРП на душу населения отн. ед.; ряд 2 - темп прироста выбросов загрязняющих веществ от стационарных источников на душу населения, отн. ед.; ряд 3 - темп прироста сброса загрязненных сточных вод в поверхностные водные объекты, отн. ед.

Источник: сост. авторами.

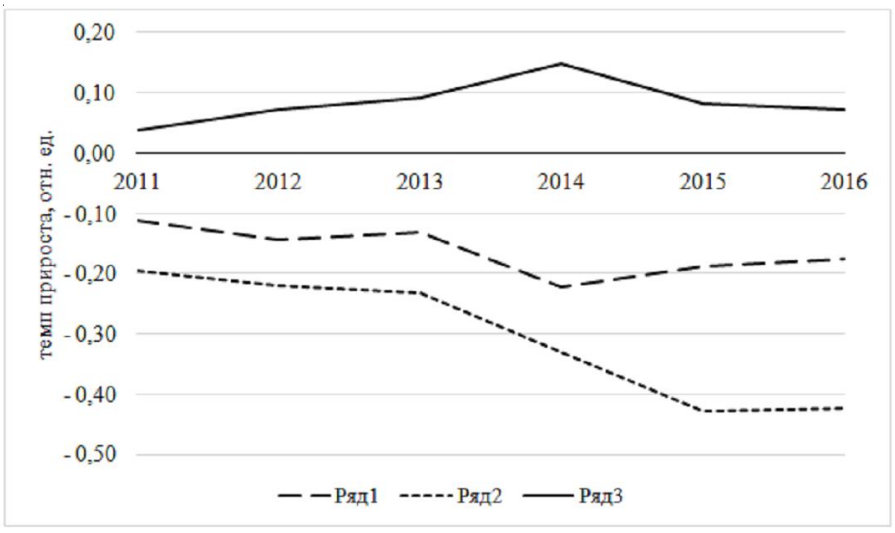

Рис. 8. Эффект декаплинга по Волгоградской области (базисный год - 2010)

Примечания: ряд1 - темп прироста физического объема ВРП на душу населения, базисные показатели, отн. ед.; ряд 2 - темп прироста выбросов загрязняющих веществ от стационарных источников на душу населения, базисные показатели, отн. ед.; ряд 3 - темп прироста сброса загрязненных сточных вод в поверхностные водные объекты, базисные показатели, отн. ед.

Источник: сост. авторами. 
Выводы. Проведенный декаплинг-анализ показывает, что по сравнению с 2010 г. Волгоградская область улучшила свои показатели эколого-экономического состояния. Наблюдается абсолютный эффект декаплинга по показателям выбросов загрязняющих веществ и объемов сброса загрязненных сточных вод: то есть при росте экономических показателей (физический объем ВРП на душу населения) антропогенное воздействие на окружающую среду снижается. Но, при сравнении цепных показателей следует отметить отсутствие эффекта декаплинга по выбросам загрязняющих веществ в 2015 и 2016 гг. и по объемам сброса загрязненных сточных вод в 2016 г. При этом характерен наихудший вариант модели декаплинг-анализа, при котором снижение экономических результатов сопровождается ростом загрязнения окружающей среды. 


\section{ГЛАВА 3. НАПРАВЛЕНИЯ СОВЕРШЕНСТВОВАНИЯ ИНСТРУМЕНТАРИЯ ФИНАНСИРОВАНИЯ ПРОЕКТОВ «ЗЕЛЕНОЙ" ЭКОНОМИКИ В РОССИЙСКОЙ ФЕДЕРАЦИИ}

\section{1. Анализ долгосрочных инструментов финансирования проектов “зеленой» экономики (зарубежный опыт)}

Значимость и приоритетность экологических проектов для современной экономики декларируется в международных и российских нормативных актах. Так в Указе Президента Российской Федерации «О национальных целях и стратегических задачах развития Российской Федерации на период до 2024 года» сказано о необходимости достижения следующих целей и показателей в сфере экологии:

«- эффективное обращение с отходами производства и потребления, включая ликвидацию всех выявленных на 1 января 2018 г. несанкционированных свалок в границах городов;

- кардинальное снижение уровня загрязнения атмосферного воздуха в крупных промышленных центрах, в том числе уменьшение не менее чем на 20 процентов совокупного объема выбросов загрязняющих веществ в атмосферный воздух в наиболее загрязненных городах;

- повышение качества питьевой воды для населения, в том числе для жителей населенных пунктов, не оборудованных современными системами централизованного водоснабжения;

- экологическое оздоровление водных объектов, включая реку Волгу, и сохранение уникальных водных систем, включая озера Байкал и Телецкое; 
- сохранение биологического разнообразия, в том числе посредством создания не менее 24 новых особо охраняемых природных территорий» ${ }^{1}$.

Решение данных задач требует реализации инвестиционных и инновационных экологических проектов и формирование эффективной системы финансирования таких проектов. Финансирование экологических проектов может осуществляться с использованием различных финансовых инструментов, которые широко используются в инвестиционном процессе. Выбор того или иного источника финансирования зависит от многих факторов (см. табл. 20), в том числе требует учета особенностей экологических проектов.

Таблицча 20

\section{Факторы формирования источников финансирования экологических проектов}

\begin{tabular}{|c|c|}
\hline $\begin{array}{c}\text { Экзогенные } \\
\text { (макро- } \\
\text { и мезо-) } \\
\text { факторы }\end{array}$ & $\begin{array}{l}\text { - степень развития финансовых институтов и рынков; } \\
\text { - стадия экономического цикла; } \\
\text { - специфика и стадия жизненного цикла отрасли, в которой } \\
\text { действует компания; } \\
\text { - эколого-экономическое состояние региона }\end{array}$ \\
\hline $\begin{array}{r}\text { Эндог } \\
\text { (кор } \\
\text { тив } \\
\text { фак }\end{array}$ & $\begin{array}{l}\text { - специфика и стадия жизненного цикла компании; } \\
\text { - размер компании и ее активы (стоимость активов, их лик- } \\
\text { видность, структура активов, их специфичность, наличие и } \\
\text { величина гудвилла компании); } \\
\text { - размер собственного капитала; } \\
\text { - существующая структура капитала (соотношение собст- } \\
\text { венных и заемных средств); } \\
\text { - структура акционерного капитала; } \\
\text { - текущая и прогнозируемая финансовая устойчивость и } \\
\text { финансовая гибкость компании; } \\
\text { - репутация компании; } \\
\text { - доступность для компании источников финансирования }\end{array}$ \\
\hline
\end{tabular}

${ }^{1}$ Указ Президента Российской Федерации от 07.05.2018 г. № 204 «О национальных целях и стратегических задачах развития Российской Федерации на период до 2024 года» // http://kremlin.ru/acts/bank/43027. 
Окончание таблицы 20

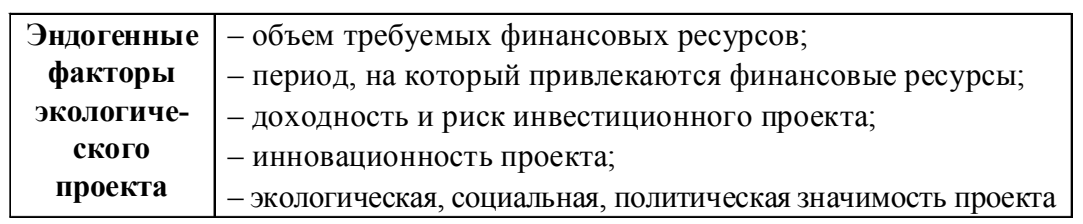

Примечание. Источник: составлено авторами ${ }^{2}$.

Для того, чтобы подчеркнуть целевую направленность средств в экологические проекты и их особенности, финансирование экологических проектов называют «зеленым финансированием», под которым понимают привлечение финансовых ресурсов из частных и государственных источников, предназначенные для развития экологической инфраструктуры, производства продукции и реализации проектов, что приводит снижению экологических рисков и переходу к зеленой экономике. Также используется понятие «климатического финансирования», которое является разновидностью зеленого финансирования и предназначено для финансирования мероприятия и проектов, направленных на снижение выбросов парниковых газов, парниковых газов или рост их поглощения, на адаптацию к последствиям изменения климата. В данном исследовании используется более широкое понятие «зеленое финансирование».

В настоящее время, по оценкам экспертов, существует проблемы финансирования экологических проектов, в частности недофинансирование проектов: так по Отчета ЮНЕП «Развитие финансовой системы с учетом устойчивого развития» «для реализации Целей устойчивого развития, включая инфраструктуру, чистую энергию, водные ресурсы и улучшение санитарных ус-

${ }^{2}$ Аникин А., Аникина И.Д., «Зеленые облигации» как финансовые инструменты реализации инвестиционных экологических проектов: возможность применения в российской экономике: параграф в колл. монографии: Научно-практические аспекты финансовой безопасности (на уровне государства, региона, организации и личности): коллективная монография; Федер. гос. авт. образоват. учреждение высш. проф. образования «Волгогр. гос. ун-т». - Курск: Изд-во ЗАО «Университетская книга», 2018. - 244 с. , с. 54-65. 
ловий, по оценкам, требуется 5-7 трлн долларов США инвестиций в год. Развивающимся странам ежегодно не хватает инвестиций на общую сумму 2,5 трлн долларов США, в то время как, если учитывать текущие тенденции, к 2020 году в ведущих экономиках будет наблюдаться дефицит долгосрочных инвестиций в размере 10 трлн долларов США в год» ${ }^{3}$. Только на климатическое финансирование планируется к 2020 году привлечь для развивающихся стран 100 млрд долл., 383 млрд долл. было выделено в 2016 году во всем мире, 600 млрд долл. требуется к 2030 году во всем мире 4 .

Поэтому требуется анализ существующих механизмов и инструментов финансирования экологических проектов, рассмотрение перспективных инструментов, использующихся в мировой практике применительно к российскому рынку «зеленых инвестиций».

Рассмотрим важнейшие международные институты, действующие в сфере зеленого финансирования/инвестирования (табл. 21).

Таблицуа 21

\section{Международные финансовые институты зеленого финансирования}

\begin{tabular}{|c|c|c|}
\hline $\begin{array}{l}\text { Название } \\
\text { института }\end{array}$ & Характеристика & Особенности инвестирования \\
\hline $\begin{array}{l}\text { Зеленый клима- } \\
\text { тический фонд }\end{array}$ & $\begin{array}{l}\text { Фонд был создан в } \\
2010 \text { году усилиями } 194 \\
\text { стран-членов Рамочной } \\
\text { конвенции ООН об из- } \\
\text { менении климата с це- } \\
\text { лью инвестирования в } \\
\text { проекты климатически } \\
\text { устойчивого развития. }\end{array}$ & $\begin{array}{l}\text { Средства предоставляются } \\
\text { аккредитованным при Фон- } \\
\text { де организациям в форме } \\
\text { следующих инструментов: } \\
\text { - Льготные займы. } \\
\text { - Субординированные дол- } \\
\text { говые обязательства Участие } \\
\text { в акционерном капитале. }\end{array}$ \\
\hline
\end{tabular}

${ }^{3}$ Необходимая финансовая система. Отчет об исследовании ЮНЕП «Развитие финансовой системы с учетом устойчивого развития». Октябрь 2015 // http:// unepinquiry.org/wp-content/uploads/2015/10/The_Financial_System_We_Need_RU.pdf

${ }^{4} \mathrm{http} / / /$ livingasia.online/2017/12/20/klimaticheskoe_finansirovanie/.

${ }^{5}$ Официальный сайт Зеленого климатического фонда https:// www.greenclimate.fund/home. 
Продолжение таблицы 21

\begin{tabular}{|c|c|c|}
\hline & Характеристика & Особенности инвестирования \\
\hline & $\begin{array}{l}\text { Фонд помогает разви- } \\
\text { вающимся странам, его } \\
\text { цель - содействие пере- } \\
\text { хода к низкоуглеродно- } \\
\text { му развитию и климати- } \\
\text { ческой адаптации }\end{array}$ & $\begin{array}{l}\text { - Гарантии. } \\
\text { - Гранты. } \\
\text { В } 2017 \text { году ресурсы Фонда } \\
\text { составили более } 10,3 \text { млрд } \\
\text { долл. США. } \\
\text { На конец } 2017 \text { г. фондом } \\
\text { одобрено } 54 \text { проекта на } \\
\text { сумму 2,65 млрд долл. }\end{array}$ \\
\hline $\begin{array}{c}\text { Глобальный } \\
\text { экологический }^{\text {фонд }^{6}}\end{array}$ & $\begin{array}{l}\text { Создан в } 1994 \text { г. Инве- } \\
\text { стирует в проекты по } \\
\text { биоразнообразию, меж- } \\
\text { дународным водам, де- } \\
\text { градации земель, хими- } \\
\text { ческих веществ и отхо- } \\
\text { дов, смягчению воздей- } \\
\text { ствия на климат, устой- } \\
\text { чивое управление лесами }\end{array}$ & $\begin{array}{l}\text { Основной финансовый ин- } \\
\text { струмент - гранты. } \\
\text { Планируемый } \\
\text { средств на 2014-2018 гг. - } \\
4,43 \text { млрд долл. }\end{array}$ \\
\hline $\begin{array}{c}\text { Группа Всемир- } \\
\text { ного банка }^{7}\end{array}$ & $\begin{array}{l}\text { Планируется выделить } \\
\text { до } 2020 \text { года до } 28 \text { \% } \\
\text { средств, необходимых } \\
\text { на климатическое фи- } \\
\text { нансирование. } \\
\text { Средства предоставля- } \\
\text { ются странам-партнерам } \\
\text { и частным компаниям }\end{array}$ & $\begin{array}{l}\text { Зарезервированный } \\
\text { средств на } 2017 \text { год } \\
61,8 \text { млрд долл. } \\
\text { В } 2015 \text { г. было предоставлено } \\
\text { более } 49 \text { млрд долл. средств. } \\
\text { Инструменты: } \\
\text { - займы, г; } \\
\text { - гранты; } \\
\text { - вложения в акционерный } \\
\text { капитал; } \\
\text { - гарантии }\end{array}$ \\
\hline $\begin{array}{c}\text { Европейский } \\
\text { банк Реконструк- } \\
\text { ции и развития }\end{array}$ & $\begin{array}{l}\text { Планируется предоста- } \\
\text { вить до } 2020 \text { года не ме- } \\
\text { нее } 40 \% \text { средств на зе- } \\
\text { леное финансирование }\end{array}$ & $\begin{array}{l}\text { Объемы зеленого финанси- } \\
\text { рования за 2006-2016 го- } \\
\text { ды - } 24 \text { млрд евро }\end{array}$ \\
\hline $\begin{array}{c}\text { Европейский } \\
\text { инвестиционный } \\
\text { банк }{ }^{8}\end{array}$ & $\begin{array}{l}\text { Планируется выделить не } \\
\text { менее } 100 \text { млрд США на } \\
\text { климатическое финанси- } \\
\text { рование до } 2020 \text { года. }\end{array}$ & $\begin{array}{l}\text { В } 2016 \text { году было выделено } \\
\text { на климатическое финанси- } \\
\text { рование } 19,6 \text { млрд евро или } \\
26,3 \% \text { от общего финанси- } \\
\text { рования }\end{array}$ \\
\hline
\end{tabular}

${ }^{6}$ Официальный сайт Глобального экологического фонда https:// www.thegef.org/.

${ }^{7}$ Официальный сайт Всемироного банка // http://www.worldbank.org/.

${ }^{8}$ http://www.eib.org/en/. 
Продолжение таблицы 21

\begin{tabular}{|c|c|c|}
\hline $\begin{array}{c}\text { Название } \\
\text { института }\end{array}$ & Характеристика & Особенности инвестирования \\
\hline & $\begin{array}{l}\text { Это составит от } 25 \% \text { и } \\
\text { более от всех инвести- } \\
\text { ций банка и от } 35 \% \text { и } \\
\text { более от общей суммы } \\
\text { инвестиций в развиваю- } \\
\text { щихся странах }\end{array}$ & \\
\hline $\begin{array}{c}\text { Климатические } \\
\text { инвестиционные } \\
\text { фонды }\end{array}$ & $\begin{array}{l}\text { Созданы в } 2008 \text { году } \\
\text { группой Всемирного } \\
\text { банка для финансирова- } \\
\text { ния инвестиций по со- } \\
\text { кращению выбросов } \\
\text { парниковых газов и } \\
\text { адаптации. Климатиче- } \\
\text { ское финансирование из } \\
\text { данного источника осу- } \\
\text { ществляется через: } \\
\text { 1) Фонд чистых техно- } \\
\text { логий (5,5 млрд долла- } \\
\text { ров США), } \\
\text { 2) Фонд стимулирования } \\
\text { развития возобновляемой } \\
\text { энергии в развивающихся } \\
\text { странах (839 млн долла- } \\
\text { ров США), } \\
3) \text { Пилотный проект по } \\
\text { климатической устойчи- } \\
\text { вости (1,2 млрд долла- } \\
\text { ров США), } \\
\text { 4) Программа лесных } \\
\text { инвестиций (775 млн } \\
\text { долларов США) }\end{array}$ & $\begin{array}{l}\text { Средства выделяются в виде } \\
\text { грантов и «мягких» креди- } \\
\text { тов (concessional or soft } \\
\text { loans) с процентами ниже } \\
\text { рыночных и с продолжи- } \\
\text { тельным периодом выплаты }\end{array}$ \\
\hline $\begin{array}{c}\text { Инвестиционное } \\
\text { учреждение ЕС } \\
\text { для Централь- } \\
\text { ной Азии }\end{array}$ & $\begin{array}{l}\text { Инвестиционный фонд } \\
\text { IFCA для Центральной } \\
\text { Азии, Азиатский инве- } \\
\text { стиционный фонд AIF, } \\
\text { Инвестиционный фонд } \\
\text { IFP для Тихоокеанского } \\
\text { региона. } \\
\text { В } 2015 \text { году объем } \\
\text { средств на зеленые проек- } \\
\text { ты составил } 830 \text { млн евро }\end{array}$ & $\begin{array}{l}\text { Предоставляет } 5 \text { видов без- } \\
\text { возмездной поддержки: } \\
- \text { прямой инвестиционный } \\
\text { грант: сокращает расходы } \\
\text { для конечных пользователей } \\
\text { и бенефициариев путем час- } \\
\text { тичного финансирования } \\
\text { инвестиционных расходов; } \\
\text { - грант на техническую под- } \\
\text { держку }\end{array}$ \\
\hline
\end{tabular}


Окончание таблицы 21

\begin{tabular}{|l|l|l|}
\hline $\begin{array}{c}\text { Название } \\
\text { института }\end{array}$ & \multicolumn{1}{|c|}{ Характеристика } & \multicolumn{1}{|c|}{ Особенности инвестирования } \\
\hline & & $\begin{array}{l}\text { субсидия с процентной } \\
\text { ставкой: сокращает расходы } \\
\text { для конечных пользователей } \\
\text { и бенефициариев путем со- } \\
\text { кращения расходов по про- } \\
\end{array}$ \\
& $\begin{array}{l}\text { центной ставке; } \\
\text { рисковый капитал: инве- } \\
\text { стиции в сокращение потен- } \\
\text { циальных рисков; } \\
\text { - залог: поручительство за те } \\
\text { или иные виды инвестиции с } \\
\text { целью снижения рисков }\end{array}$ \\
\hline
\end{tabular}

Примечание. Источники: составлено автором по : https://alatransit.kz/sites/ default/files/3_e.suleymenov_finansirovanie_ekologicheskih_proektov.pdf; http:// www.worldbank.org/; http://livingasia.online/2017/12/20/klimaticheskoe_finansirovanie/; http://bookshop.europa.eu.

Анализ показывает интерес финансовых институтов к финансированию «зеленой» экономики, рост объемов финансирования, расширение инструментов и круга инвесторов. Для финансирования проектов зеленой экономики используются средства различных фондов (см. табл. 18). В российской экономике возможно использование средства Фонда национального благосостояния для финансирования инфраструктурных проектов. Так, согласно ст. 96.11, п. 4 БК РФ средства фонда могут быть размещены в «долговые обязательства и акции юридических лиц, в том числе российские ценные бумаги, связанные с реализацией самоокупаемых инфраструктурных проектов, перечень которых утверждается Правительством Российской Федерации» ${ }^{9}$.

Одним из инновационных и наиболее перспективных, по нашему мнению, источников финансирования экологических проектов являются «зеленые облигации». Рассмотрим особенности их

${ }^{9}$ «Бюджетный кодекс Российской Федерации» от 31.07.1998 № 145-Ф3 (ред. от 03.08.2018) http://www.consultant.ru/document/cons_doc_LAW_19702/ 1b6959f23cc516d0e11ddc2e213ca2dca83560df/, ст. 96.11. 
применения и тенденции развития в мировой экономике, а также возможность применения в российской практике. В научной литературе и практике используются различные названия финансовых инструментов, применяемых для обеспечения реализации проектов в сфере экологии: экологические облигации (pollution control revenue bonds), климатические облигации (climate awareness bonds), инфраструктурные облигации, «зеленые» облигации (green bonds). В данном исследовании мы будем пользоваться термином «зеленые» облигации как получившим наибольшее распространение.

Особенность «зеленых» облигаций по сравнению с классическими - целевое назначение, они предназначены для финансирования проектов в области предотвращения изменения климата, охраны окружающей среды, энергоэффективности, энергосбережения. Эмитентами облигаций выступают: государство, муниципальные органы, корпорации, финансовые институты. В мировой практике «зеленые» облигации получают в настоящее время все большее распространение как инструмент целевого финансирования экологических проектов. Впервые «зеленые» облигации были выпущены в 2007 г. как climate awareness bonds для финансирования проектов в области альтернативных источников энергии и повышения энергоэффективности, а финансовые инструменты под названием «зеленые» облигации (green bonds) выпустил Международный банк реконструкции и развития в 2008 г. ${ }^{10}$. Развитие рынков зеленых облигаций идет активными темпами и поддерживается международными финансовыми организациями. Так в 2017 г. вышла обновленная версия Принципов зеленых облигаций (Green Bond Principles) ${ }^{11}$, которая направлена на обеспечение прозрачности рынка инвестиций в экологические проекты и способствует росту информационной эффективности рынка и установлению справедливого ценообразо-

${ }^{10}$ Богачева О.В., Смородинов О.В. «Зеленые облигации как важнейший инструмент финансирования «зелёных» проектов // Финансовый журнал. - 2016. № 2. - С. 70-81, с. 70 .

${ }^{11} \mathrm{https}$ ://www.icmagroup.org/green-social-and-sustainability-bonds/greenbond-principles-gbp/. 
вания. В 2016 г. дискуссия о «зеленых» финансах по инициативе Китая впервые была включена в повестку саммита G20 ${ }^{12}$. Инициатива Китая не случайна: в первом полугодии 2018 г. доля китайских зеленых облигаций на рынке составляет 9,3 млрд долл. США и они занимают 12 \% рынка. А весь рынок (общий объем выпуска зеленых облигаций), по данным Climate Bonds Initiative in partnership with China Central Depositing and Clearing Co, в первом полугодии 2018 года составил 76,9 млрд долл. США ${ }^{13}$. Ма Цзюнь - главный экономист Народного банка Китая отметил, что «сейчас в мире довольно хороший спрос на так называемые «зеленые облигации» ${ }^{14}$ и одним из предложений китайских банкиров стало упрощение механизма трансграничных инвестиций для финансирования экологических инициатив и проектов. При этом у рынка огромный потенциал роста: Ма Цзюнь привел такие цифры, характеризующие рынок: «Глобальный спрос на «зеленые» инвестиции огромный. Согласно ряду исследований, объем вложений в эту сферу мог бы составить от 3 до 7 триллионов долларов в год. Но существующий рынок «зеленых финансов» все еще очень мал. К примеру, выпуск «зеленых облигаций» составляет меньше $1 \%$ от общей эмиссии ценных бумаг. На рынке кредитования только несколько процентов от общего числа выданных кредитов идет под проекты, которые можно классифицировать как “зеленые”» ${ }^{15}$. Таким образом исследова-

${ }^{12}$ На саммите G20 по инициативе Китая впервые обсудят «зеленые финансы» 31.08.2016. Сайт CNTV// http://russian.cctv.com/2016/08/31/VIDE7Xrmx Kkui1JtQbWaPcDz160831.shtml.

13 «Global green bond issuance picked up pace in Q2, and total aligned issuance worldwide reached USD76.9bn for H1 2018. With USD9.3bn worth of green bonds aligned with international green bond definitions, China represents $12 \%$ of the global market over this period. Total issuance from China was USD13bn, but USD3.7bn is not aligned» (Источник: «China Green Bond Market Mid-Year Report 2018»// https://www.climatebonds.net/2018/07/china-green-bond-market-mid-year-report2018-中国绿色债券市场半年报-2018).

${ }^{14}$ На саммите G20 по инициативе Китая впервые обсудят «зеленые финансы» 31.08.2016. Сайт CNTV // http://russian.cctv.com/2016/08/31/VIDE7X rmxKkui1JtQbWaPcDz160831.shtml.

15 Там же. 
ние рынка «зеленых финансов» и его инструментов является актуальным и своевременным. Анализ мирового опыта и тенденций развития данного рынка поможет формулированию предложений о совершенствовании инструментария финансирования экологических проектов в российской экономике.

Рынок «зеленого финансирования» существует уже 12 лет, в 2017 году объем рынка составил 161 млрд долл. ${ }^{16}$, в 1 полугодии 2018 - уже 76,9 млрд долл. ${ }^{17}$, оценка на 2018 год - 250 млрд долл. ${ }^{18}$. В 2019 г. рынок «зеленых» облигаций продолжает расти. К июню 2019 г. только объем эмиссий по оценкам некоммерческой организации в области зеленых финансов Climate Bonds Initiative coставил 20 млрд долл. По ожиданиям Climate Bonds Initiative объем выпуска зеленых облигаций по итогам 2019 года может достигнуть 250 млрд долл. ${ }^{19}$

Рынок развивался скачкообразно: в июле 2007 года - первый в истории выпуск на сумму 600 млн евро. И только к 2013 году размер эмиссии зеленых облигаций преодолел годовую отметку в 10 млрд долл. ${ }^{20}$, продемонстрировав за четыре года рост в четыре раза. На европейском рынке облигаций зеленые, социальные и устойчивые облигации, за исключением государственных выпусков, уже составляли в среднем 4-5 \% с 2017 г. и выросли примерно до $10 \%$ от общего объема облигаций, выпущенных европейскими эмитентами в последнем квартал 2018 г. ${ }^{21}$. На мировых фон-

${ }^{16}$ Френч Г. Трава у дома: какое будущее ждет рынок зеленых облигаций. 26.09.2017/Интернет-сайт Forbs: http://www.forbes.ru/kompanii/350575-trava-udoma-kakoe-budushchee-zhdet-rynok-zelenyh-obligaciy.

${ }^{17}$ «China Green Bond Market Mid-Year Report 2018»// https:// www.climatebonds.net/2018/07/china-green-bond-market-mid-year-report-2018中国绿色债券市场半年报-2018.

${ }^{18} \mathrm{https}: / /$ www.climatebonds.net/.

${ }^{19} \mathrm{https}: / /$ www.climatebonds.net/.

${ }^{20}$ Френч Г. Трава у дома: какое будущее ждет рынок зеленых облигаций. 26.09.2017/Интернет-сайт Forbs: http://www.forbes.ru/kompanii/350575-trava-udoma-kakoe-budushchee-zhdet-rynok-zelenyh-obligaciy.

${ }^{21}$ Report of the Technical Expert Group (TEG) subgroup on Green Bond Standard. Proposal for an EU Green Bond Standard. Interim Report. Document for feedback. Green Bond Standard Subgroup 6 March 2019, c. 28. 
довых биржах существуют сегменты «зеленых» облигаций, что повышает ликвидность и объемы сделок с данными финансовыми инструментами (табл. 22).

Таблица 22

\section{Фондовые биржи, имеющие секции «зеленых» облигаций}

\begin{tabular}{|l|l|r|}
\hline \multicolumn{1}{|c|}{ Name of Stock Exchange } & \multicolumn{1}{c|}{ Type of dedicated section } & \multicolumn{1}{c|}{ Launch date } \\
\hline Oslo Stock Exchange & Green bonds & January 2015 \\
\hline Stockholm Stock Exchange & Sustainable Bonds & June 2015 \\
\hline London Stock Exchange & Green bonds & July 2015 \\
\hline Mexico Stock Exchange & Green bonds & August 2016 \\
\hline Luxembourg Stock Exchange & Luxembourg Green Exchange & September 2016 \\
\hline Borsa Italiana & Green and Social Bonds & March 2017 \\
\hline Shanghai Stock Exchange & Green bonds & March 2016 \\
\hline Taipei Stock Exchange & Green bonds & May 2017 \\
\hline Johannesburg Stock Exchange & Green bonds & October 2017 \\
\hline Japan Exchange Group & Green and Social Bonds & January 2018 \\
\hline
\end{tabular}

Примечание. Источник: Climate-awareness-bond. https:/www.climatebonds.net /green-bond-segments-stock-exchanges.

Приведем примеры выпуска «зеленых» облигаций различными эмитентами:

- HSBC (банковский холдинг) в 2015 году выпустил зеленые облигации на сумму $€ 500$ млн Привлеченные средства пошли на финансирование 20 проектов в 10 странах, включая строительство ветряных электростанций в Ирландии, Германии, Турции и других странах, солнечных электростанций в Чехии, Южной Африке и Испании, а также создание предприятий по переработке отходов во Франции и Великобритании ${ }^{22}$.

- «Зеленые» ценные бумаги на рынок выпустили французская энергетическая группа EDF, шведская компания Group Vasakronan, занимающаяся недвижимостью, и Bank of America Merill Lynch. У последнего ставка дохода по облигациям на

${ }^{22}$ Report of the Technical Expert Group (TEG) subgroup on Green Bond Standard. Proposal for an EU Green Bond Standard. Interim Report. Document for feedback. Green Bond Standard Subgroup 6 March 2019, c. 28. 
500 миллионов долларов составила 1,359 процента, отмечает The Wall Street Journal» ${ }^{23}$.

- в августе 2017 г. шотландская компания SSE привлекла 600 млн евро в результате крупнейшего выпуска зеленых облигаций в истории Великобритании. Спрос на данные бумаги компании существенно превысил предложение: подписка на восьмилетние зеленые облигации SSE превысила объем выпуска в 3 раза, ставка купона составила $0,875 \%$ годовых ${ }^{24}$.

- в 2019 г. крупнейшей эмиссией сертифицированных зеленых облигаций июня стал выпуск зеленых суверенных зеленых облигаций Правительства Чили в объеме 1,5 млрд долл. Чили стала первой страной в Латинской Америке, выпустившей суверенные сертифицированные зеленые облигации ${ }^{25}$.

Многие страны мира используют зеленые облигации в практике финансирования (табл. 23).

Таблицча 23

\section{Выпуск зеленых облигаций в различных странах мира}

\begin{tabular}{|c|c|}
\hline Страна & $\begin{array}{c}\text { Выпуск зеленых облигаций, } \\
\text { млрд. долл. США }\end{array}$ \\
\hline Аргентина & 0.4 \\
\hline Австралия & 4,1 \\
\hline Бангладеш & 0,0 \\
\hline Барбадос & 0,0 \\
\hline Бразилия & 3,9 \\
\hline Камбоджи & 0,0 \\
\hline Канада & 5,3 \\
\hline Китай & 35,8 \\
\hline Колумбия & 0,3 \\
\hline Коста Рика & 0,5 \\
\hline Эквадор & 0,0 \\
\hline Египет & 0,0 \\
\hline
\end{tabular}

${ }^{23}$ На рынках появились зеленые облигации// Интернет сайт Lenta.ru https://lenta.ru/news/2013/12/02/bonds//.

24 Зеленые облигации - растет рынок экологических финансовых инструментов. // http://een ergy.media/2017/10/03/zelenye-obligatsii-rastet-rynokekologicheskih-finansovyh-instrumentov/.

${ }^{25} \mathrm{https}$ ://www.climatebonds.net/. 
Окончание таблицы 23

\begin{tabular}{|c|c|}
\hline Страна & $\begin{array}{c}\text { Выпуск зеленых облигаций, } \\
\text { млрд. долл. США }\end{array}$ \\
\hline Эфиопия & 0,0 \\
\hline Франция & 34.8 \\
\hline Германия & 20,0 \\
\hline Гондурас & 0,0 \\
\hline Индия & 5,5 \\
\hline Индонезия & 0,0 \\
\hline Италия & 3,0 \\
\hline Япония & 2,3 \\
\hline Казахстан & 0,0 \\
\hline Кения & 0,0 \\
\hline Республика Корея & 1,7 \\
\hline Российская Федерация & 0,0 \\
\hline Саудовская Аравия & 0,0 \\
\hline Сингапур & 0,6 \\
\hline Южная Африка & 1,3 \\
\hline Шри Ланка & 0,0 \\
\hline Швейцария & 0,1 \\
\hline Таиланд & 0,0 \\
\hline Турция & 0,0 \\
\hline Великобритания & 0,0 \\
\hline США & 45,6 \\
\hline Вьетнам & 0,0 \\
\hline
\end{tabular}

Примечание. Источник: unepinquiry.org/countries/. Данные на сентябрь 2017 г.

Отметим юридические особенности выпуска «зеленых» облигаций. При эмиссии «зеленых» облигаций эмитенты ориентируются на «Принципы зеленых облигаций» ${ }^{26}$, которые представляют собой добровольные стандарты эмиссии данных ценных бумаг. Цель данных Принципов - обеспечить участникам рынка достоверную информацию для лучшего понимания ожидаемых результатов от инвестирования в экологические проекты посредством «установления стандартов прозрачности, раскрытия информации и отчетности» ${ }^{27}$. Следует отметить, что Принципы носят

${ }^{26} \mathrm{https}$ ://www.icmagroup.org/green-social-and-sustainability-bonds/greenbond-principles-gbp/.

27 Там же. 
рекомендательный характер. Они основываются на четырех элементах: 1) использование средств, 2) процесс оценки и отбора проектов, 3) управление средствами, 4) отчетность.

1. Использование средств. Поступления от эмиссии «зеленых» облигаций должны направляться на реализацию зеленых проектов, в т.ч. на НИОКР. Проекты должны приносить экологическую пользу, которую необходимо оценить с помощью количественных и качественных показателей. При рефинансировании средств необходимо разъяснение того, в какие проекты средства будут рефинансироваться. Принципы включают примерный список категорий экологических проектов:

«- возобновляемые источники энергии (включая производство, передачу, оборудование и изделия);

- эффективность использования электроэнергии (энергоэффективность в новых и отремонтированных зданиях, хранение электроэнергии, центральное теплоснабжение, интеллектуальные сети, оборудование и изделия);

- предотвращение загрязнения и контроль (включая проекты в сфере очистки сточных вод, сокращения выбросов в атмосферу, контроля за парниковыми газами, восстановления почв, предотвращения загрязнений, сокращения загрязнений, переработки отходов, эффективной переработки отходов в электроэнергию, производства товаров с добавленной стоимостью из отходов и в результате переработки и связанного с указанными сферами деятельности контроля состояния окружающей среды);

- экологически устойчивое управление живыми природными ресурсами и землепользованием (в том числе экологически устойчивое сельское хозяйство, экологически устойчивое животноводство, не причиняющие ущерба климату сельскохозяйственные технологии, например, защита биологических культур или капельное орошение, экологически устойчивое рыболовство и аквакультура, экологически устойчивое лесное хозяйство, включая лесонасаждение или лесовосстановление, сохранение или восстановление природных ландшафтов);

- сохранение земного и водного биоразнообразия (включая охрану прибрежных, морских и водораздельных сред); 
- экологически чистый транспорт (например, электрический, гибридный, общественный, железнодорожный, немоторизованный, мультимодальный транспорт, инфраструктура для экологически чистых транспортных средств и сокращение вредных выбросов);

- устойчивое управление водными ресурсами и сточными водами (включая устойчивую инфраструктуру для чистой и/или питьевой воды, очистку сточных вод, устойчивые городские системы дренажа и регулирование речного русла, и другие методы противопаводковой защиты);

- адаптация к изменению климата (включая системы информационной поддержки, такие как системы наблюдения за климатом и системы раннего предупреждения);

- экологически эффективные и/или адаптированные продукты безотходной экономики, производственные технологии и процессы (такие как разработка и внедрение экологически чистых продуктов, экомаркировка или экологическая сертификация, экономная упаковка и распределение);

- зеленые здания, отвечающие региональным, национальным или международно-признанным стандартам или сертификациям».

2. Процесс оценки и отбора проектов. Делается акцент на необходимости донесения целей проекта до инвесторов; раскрытие процедуры соответствия проектов категории экологических; соответствующие квалификационные критерии и процедуры, позволяющие оценить и управлять экологическими и социальными рисками.

\section{3. Управление средствами.}

4. Отчетность. Эмитентам необходимо предоставлять отчет по проектам, который должен содержать такую информацию как: список экологических проектов, описание проектов, суммы направленных средств, ожидаемые результаты и эффекты.

Кроме того, Принципы рекомендуют эмитентам использовать независимую оценку для подтверждения соответствия зеленых облигаций четырем представленным выше Принципам.

Принципы носят добровольный характер, получение соответствия облигаций статуту «зеленый» формально не влияет на рейтинг. Но отметим, что рейтинг таких облигаций высок, в том чис- 
ле и потому, что эмитентами в большинстве являются крупнейшие банки, компании, государственные и муниципальные органы, такие как Всемирный банк (МБРР), Европейский инвестиционный банк, Международная финансовая корпорация, Toyota, Ile de France, Electricite de France, Apple Ink. и другие. В тоже время специалисты отмечают, что при условии добровольности Принципов инвесторы не застрахованы от риска не следования эмитентами принимаемым обязательствам. Так исследователи Гутборг М., Храплива Ю, Володин С. цитируют проспекты эмиссии зеленых облигаций и подчеркивают, что в них «допускается возможность невыполнения таких обещаний» ${ }^{28}$, что увеличивает моральный риск инвесторов таких ценных бумаг.

В 2019 г. в рамках Плана действий по финансированию устойчивого развития Европейская комиссия поручила TEG подготовить доклад о стандарте зеленых облигаций ЕC (EU green bond standard, EU GBS). Промежуточный доклад о стандарте зеленых облигаций ЕС был подготовлен в марте 2019 года (TEG interim report on EU green bond standard).

Каковы интересы участников рынка «зеленого финансирования»? Ключевыми инвесторами зеленых облигаций являются пенсионные фонды и страховые компании, инвестиционные фонды, которые используют в своей деятельности «длинные» деньги и ориентированы на консервативные инвестиционные страте-

${ }^{28}$ Проспект компании Apple Ink.: «Рыночная цена облигаций может быть подвержена влиянию любого отказа от использования доходов от облигаций на соответствующие экологические проекты... Несмотря на то что мы согласились с определенными обязательствами по представлению отчетности, как описано в разделе «Использование доходов», невыполнение таких обязательств небудет считаться дефолтом в рамках этого Соглашения». Проспект города СентПол: «Дефолт в соответствии с настоящим Свидетельством о раскрытии не считается дефолтом по облигациям серии $2017 \mathrm{C}$ («зеленые облигации») и единственным средством правовой защиты в случае любого нарушения эмитентом требований настоящего Свидетельства о раскрытии информации является обращение в суд». (Цитировано по : Гутборг М., Храплива Ю, Володин С. «Зеленые облигации» как новый финансовый инструмент и перспективы их внедрения в России. // Валютное регулирование. Валютный контроль. - 2017. - № 9. - С. 44-52, c. 48$)$. 
гии. Их интерес к зеленому финансированию высок и определяется такими факторами как ${ }^{29}$ : быстрое размещение облигаций на рынках с момента официального начала продаж; спрос (сумма подписки) на такие облигации часто выше размера эмиссии; опросы инвесторов свидетельствуют о повышенном интересе к зеленым финансовым инструментам; развитием фондов зеленых инвестиций. Инвесторов привлекает высокий рейтинг зеленых финансовых инструментов (45 \% зеленых облигаций, выпущенных в 2014 г. имели рейтинг А3, $16 \%$ - А2) а эмитентов низкие купонные выплаты (доходность) и длительный срок погашения (более $60 \%$ бумаг - более 10 лет, около $30 \%$ - 5-10 лет, около $6 \%-3-5$ лет) ${ }^{30}$. Эксперты отмечают, что спрос на зеленые облигации превышает предложение, а управляющие фондов «диверсифицируют свои инвестиционные критерии, включая зеленый фактор», отмечает Financial Times ${ }^{31}$. Многие крупные институциональные инвесторы отказываются от инвестирования с проекты, не соответствующие принципам «зеленой экономики». Так «японский государственный пенсионный инвестиционный фонд, под управлением которого находится \$1,3 трлн, поставил перед собой цель размещать 10 \% своих активов в компании, соответствующие определенным экологическим, социальным и управленческим (governance) критериям» ${ }^{32}$. «Пенсионный фонд Дании PenSam принял решение отказаться от инвестиций в 26 акций нефтяных компаний совокупной стоимостью $€ 17,4$ млн Решение о пересмотре структуры инвестиционного

${ }^{29}$ Богачева О.В., Смородинов О.В. «Зеленые облигации как важнейший инструмент финансирования «зелёных» проектов // Финансовый журнал. - 2016. № 2. - С. 70-81, c. 73-74.

${ }^{30}$ Согласно данным, приведенным в: Богачева О.В., Смородинов О.В. «Зеленые облигации как важнейший инструмент финансирования «зелёных» проектов // Финансовый журнал. - 2016. - № 2. - С. 70-81, с. 75.

31 «Зеленые облигации - растет рынок экологических финансовых инструментов. // http://eenergy.media/2 017/10/03/zelenye-obligatsii-rastet-rynokekologicheskih-finansovyh-instrumentov/.

32 Зеленые облигации - растет рынок экологических финансовых инструментов // http://eenery.media/2017/10/03/zelenye-obligatsii-rastet-rynokekologicheskih-finansovyh-instrumentov/. 
портфеля фонда принято в целях поддержки Парижского соглашения ООН об изменении климата, регулирующее меры по снижению углекислого газа в атмосфере с 2020 года. Начиная с 2016 года пенсионный фонд уже не инвестирует в более чем 100 акций компаний, занятых в сфере производства нефти, угля и битуминозных песков» ${ }^{33}$. «4 июня 2019 года опубликована информация о том, что шведский пенсионный фонд АР2 принял решение отказаться от инвестиций в 60 табачных компаний, а также в акции компаний, связанных с проведением модернизации и технического обслуживания систем ядерного оружия. Решение о пересмотре структуры инвестиционного портфеля фонда принято в целях поддержки конвенции ООН в области борьбы против табака и табачной продукции, а также международного договора о нераспространении ядерного оружия» ${ }^{34}$.

Инвесторы Германии активно инвестируют в зеленую экономику страны. Берлинская газета Tagesspiegel летом 2019 г. опубликовала исследование об инвестициях в зеленую экономику Германии, в котором отмечает, что за последние три года «в экологические акции, фонды и сертификаты было инвестировано порядка 3 млрд евро. Только за первые три квартала текущего года в котирующиеся на бирже экологические акции было вложено 552 млн евро. За последние же два года капиталовложения в охрану окружающей среды увеличились в 36 раз. Только в 18 допущенных в Германии экологических фондов было вложено 3 млрд евро. Среднее увеличение стоимости экологических ценных бумаг за девять месяцев прошлого года составило $24 \%{ }^{35}$.

Согласно опросу, проведенному немецкой управляющей компанией Union Investment Institutional «92 \% инвестиционных компаний учитывают ESG факторы при вложении средств, затем следуют благотворительные организации и религиозные организации -

${ }^{33}$ www.ipe.com.

${ }^{34}$ Ежемесячный обзор «Устойчивое развитие и зеленые инвестиции», 2019. - № 6. - 17 с., с. 12. Национальная ассоциация концессионеров и долгосрочных инвесторов в инфраструктуру (НАКДИ) // www.investinfra.ru.

35 Зеленые облигации на Московской бирже. Б. Николаев. Независимая газета. 14.01.2019// http://www.ng.ru/ng_energiya/2019-01-14/15_7481_energy10.html. 
$86 \%$, пенсионные фонды - 56 \%, страховые компании - $49 \%$, банки - $41 \%$, крупные финансовые компании - $40 \%$. По мнению опрошенных компаний, стоимость активов, которые находятся в инвестиционном портфеле, является очень важным мотивационным фактором для интеграции ESG-факторов в инвестиционную стратегию» ${ }^{36}$. При этом Tagesspiegel отмечает, что «доля экологических капиталовложений в целом составляет пока лишь 0,4 \% всех капиталовложений ${ }^{37}$.

Подход к инвестированию, применяемый в данных примерах, является «ответственным инвестированием» и получает все большее распространение среди инвесторов, влияющее на мировоззрение инвесторов и оказывающее влияние на финансовые рынки. Этот феномен лег в основу исследования французской управляющей компании Natixis Investment Managers, результаты которого она опубликовала в мае 2019 г. ${ }^{38}$.

«Согласно выводам управляющей компании, профессиональные инвесторы по всему миру все больше начинают осознавать риски и возможности, которые связаны с экологическими, социальными и факторами корпоративного управления (ESG). Так, согласно проведенному опросу, шесть из десяти институциональных инвесторов полагают, что вложение средств с учетом ESG-факторов может принести значительный доход» ${ }^{39}$.

На мировых рынках «зеленые» облигации обращаются не только как классические облигации, развиваются и другие виды: проектные облигации; облигации, обеспеченные потоком платежей (доходные); облигации, обеспеченные имуществом (подробнее - таблица 24).

${ }^{36} \mathrm{https}: / / \mathrm{www}$. ipe.com/.

37 Зеленые облигации на Московской бирже. Б. Николаев. Независимая газета. 14.01.2019// http://www.ng.ru/ng_energiya/2019-01-14/15_7481_energy10.html.

${ }^{38}$ Ежемесячный обзор «Устойчивое развитие и зеленые инвестиции», 2019. - № 5. - 19 с., с. 4. Национальная ассоциация концессионеров и долгосрочных инвесторов в инфраструктуру ((НАКДИ) // www.investinfra.ru.

${ }^{39}$ Ежемесячный обзор «Устойчивое развитие и зеленые инвестиции», 2019. - № 5. - 19 с., с. 4. Национальная ассоциация концессионеров и долгосрочных инвесторов в инфраструктуру (НАКДИ) // www.investinfra.ru. 
Виды «зеленых» облигаций и их особенности

\begin{tabular}{|l|l|}
\hline \multicolumn{1}{|c|}{$\begin{array}{c}\text { Виды «зеленых» } \\
\text { облигаций }\end{array}$} & \multicolumn{1}{|c|}{ Особенности } \\
\hline $\begin{array}{l}\text { Облигации с общим } \\
\text { обязательсвом }\end{array}$ & $\begin{array}{l}\text { Выплаты по облигациям не связаны с результа- } \\
\text { тами реализации зеленых проектов, инвесторы не } \\
\text { несут проектных рисков }\end{array}$ \\
\hline Проектные облигации & $\begin{array}{l}\text { Доходы обеспечены реализацией зеленого проек- } \\
\text { та. Инвесторы имеют право прямого воздействия } \\
\text { на риск проекта без обращения к эмитенту. Об- } \\
\text { лигации обеспечены активами эмитента (не толь- } \\
\text { ко зелеными) }\end{array}$ \\
\hline Доходные облигации & $\begin{array}{l}\text { Доходы -от реализации товаров и услуг зеленого } \\
\text { проекта, облигации обеспечены только «зелены- } \\
\text { ми» активами }\end{array}$ \\
\hline $\begin{array}{l}\text { Секъюритизированные } \\
\text { облигации }\end{array}$ & $\begin{array}{l}\text { Облигации, обеспеченные пулом активов, м.б. } \\
\text { как 1) изъяты из баланса эмитента, 2) так и оста- } \\
\text { ваться на балансе эмитента. Риск неисполнения } \\
\text { обязательств ложится на инвестора. Право рег- } \\
\text { ресса обращается к пулу зеленых (или обеспечи- } \\
\text { вающих) активов, являющихся залогом. Инве- } \\
\text { сторы диверсифицируют риски, инвестируя в не- } \\
\text { большие неликвидные активы. Эмитенты полу- } \\
\text { чают доступ к дешевому финансированию }\end{array}$ \\
\hline
\end{tabular}

Примечание. Источник: составлено авторами по: https://www.climatebonds.net/ certification/types-of-bonds; Богачева О.В., Смородинов О.В. «Зеленые облигации как важнейший инструмент финансирования «веленых» проектов // Финансовый журнал. - 2016. - № 2. - С. 70-81.

Появляются новые виды экологических финансовых инструментов: так, наряду с «зелеными» облигациями выпускаются «голубые» облигащии, предназначенные для финансирования проектов в области развития рыбного хозяйства, планируется разработка критериев финансовых инструментов для проектов и программ в сфере обращения с отходами - The Waste Management Criteria, на основе которых будет проводиться отбор проектов, которые соответствуют концепции низкоуглеродной экономики и целям, зафиксированным в Парижском соглашении по ограничению глобального повышения температуры выше $2{ }^{\circ} \mathrm{C}^{40}$.

${ }^{40} \mathrm{https}$ ://www.climatebonds.net/. 
Планируется выпуск «переходных» облигаций (transition bonds). С инициативой их выпуска в июне 2019 г. выступила французская управляющая компания AXA Investment Managers. Средства, привлеченные путем выпуска данных ценных бумаг, помогут компаниям, не имеющим возможности выйти на рынок зеленых облигаций, стать более экологичными ${ }^{41}$. Рост более широкого диапазона социально сознательных долговых обязательств отмечает в своем отчете за 2018 г. компания Climate Bonds Initiative, констатируя отчетливый рост таких финансовых инструментов как облигации ЦУР, социальные облигации, голубые облигации, что расширяет возможности для ответственных инвестиций ${ }^{42}$.

Инвестиционные фонды не только увеличивают долю «зеленых» финансовых инструментов в своих портфелях, но и начинают поддерживать не только крупные экологические проекты, но и проекты среднего и малого бизнеса. Так 9 июля 2019 года на Международном финансовом форуме (International Finance Forum) в Париже французская управляющая компания Amundi совместно с Европейским инвестиционным банком (European Investment Bank, EIB) объявили о совместном партнерстве, направленном на развитие инструментов зеленого финансирования в Европе (Partnership to expand Green Finance in Europe). В рамках партнерства они запускают программу The Green Credit Continuum programme, которая предполагает создание инвестиционного фонда, средства которого будут вложены в высокодоходные корпоративные зеленые облигации (highyield corporate green bonds), частные зеленые долговые финансовые инструменты (green private debt) и зеленые секьюритизированные зеленые кредиты (green securitised credit). Первоначальные инвестиции Европейского инвестиционного банка в формируемый фонд составят около $\$ 60$ млн с возможностью дополнительного увеличения вложений в течение трех лет до 11 млрд Средства фонда будут направлены на финансирование небольших зеле-

${ }^{41}$ Ежемесячный обзор «Устойчивое развитие и зеленые инвестиции», 2019. - № 6. - 17 с., с. 10. Национальная ассоциация концессионеров и долгосрочных инвесторов в инфраструктуру (НАКДИ) // www.investinfra.ru.

${ }^{42}$ Green bonds the state of the market, 2018 // https:/www.climatebonds.net/. 
ных проектов, а также малых и средних компаний, деятельность которых связана с охраной окружающей среды ${ }^{43}$.

Выводы. Таким образом «зеленые» облигации характеризуются следующими особенностями: 1) целевой характер инвестиций в экологические проекты; 2) наличие международных и национальных стандартов, носящих добровольный характер, но в отдельных странах (Китай) стандарты обязательны ${ }^{44}$; 3) высокий рейтинг зеленых облигаций, который свидетельствует о более низком риске и повышает привлекательность инвестиций в зеленые финансы; 4) длительные сроки обращения зеленых облигаций, которые репрезентативны срокам реализации и окупаемости экологических проектов, в отличие от других, обычно более коротких способов финансирования; 5) признание данного инструмента со стороны участников рынка, что способствует быстрому развитию зеленых сегментов фондового рынка даже в развивающихся странах.

\section{2. Совершенствование механизмов и инструментов финансовой поддержки развития «зеленой» экономики в российской экономике}

Среди российских ученых, занимающихся исследованием проблем финансирования экологических проектов, в том числе с помощью «зеленых» облигаций, отметим работы О.В. Богачевой и О.В. Смородинова (Центр бюджетной политики Научно-исследовательского финансового института) ${ }^{45}$, Е. Тютюкиной, Т. Се-

${ }^{43}$ www.ipe.com; about.amundi.com.

${ }^{44}$ Богачева О.В., Смородинов О.В. «Зеленые облигации как важнейший инструмент финансирования «зелёных» проектов // Финансовый журнал. - 2016. № $2 .-$ С. $70-81$, с. 79 .

${ }^{45}$ Богачева О.В., Смородинов О.В. «Зеленые облигации как важнейший инструмент финансирования «зелёных» проектов // Финансовый журнал. - 2016. № 2. - С. 70-81; Богачева О.В., Смородинов О.В. Государственный мера по организации и развитию рынка «зеленых» облигаций // Финансовый журнал. 2016. - № 3. - С. 55-65. 
даш, Е. Каменевой (Финансовый университет при Правительстве Российской Федерации) ${ }^{46}$, М. Гутборга, Ю. Храпливой (компания Baker McKenzie), С. Володина (ВШЭ) ${ }^{47}$ и др.

В российской экономике «зеленые» облигации до сих пор не эмитируются несмотря на положительные мнения специалистов о возможностях использования такого рода финансовых инструментов и необходимость поиска дополнительных источников финансирования экологических проектов, помимо бюджетных средств. Как исключение приведем факт из работы Е. Тютюкиной, Т. Седаш «Экологические облигации и депозиты как источник финансирования природоохранных мероприятий», в которой отмечается, что в российской экономике муниципальными и региональными органами власти могут быть эмитированы облигации внутреннего экологического займа (ОВЭ3) для финансирования региональных проектов по охране окружающей среды и как пример эмиссии экологических облигаций в России приводится эмиссия облигаций областного займа «Ярославский экологический заем 1995-1998 гг.», утвержденная постановлением губернатора Ярославской области в 1995 г. ${ }^{48}$.

46 Тютюкина Е., Седаш Т. Экологические облигации и депозиты как источник финансирования природоохранных мероприятий // Финансовая жизнь. 2015. - № 3. - С. 58-62; Седаш Т. Экономические инструменты стимулирования природоохранной деятельности: анализ зарубежного опыта // Финансы и кредит. - 2015. - № 7. - С. 54-63; Каменева Е., Седаш Т. Финансовый инструментарий повышения энергоэффективности экономики России // Менеджмент и бизнес-администрирование. - 2015. - № 4. - С. 93-102; Седаш Т. Переход к «зеленой» экономике в России: миф или реальность? // Финансовая жизнь. - 2016. № 1. - С. 6-11; Седаш Т. Зарубежный опыт финансирования инфраструктурных и энергосберегающих проектов // Управленческие науки в современном мире. 2017. Т. 1. С. 463-465; Формирование финансовой поддержки банками и финансовыми организациями инвестиционных проектов и мероприятий по энергосбережению и повышению энергоэффективности : колл. монография / под ред. И.В. Ларионовой. - М. : Изд-во Кнорус, 2017, 120 с.

${ }^{47}$ Гутборг М., Храплива Ю, Володин С. «Зеленые облигации»как новый финансовый инструмент и перспективы их внедрения в России // Валютное регулирование. Валютный контроль. - 2017. - № 9. - С. 44-52.

48 Тютюкина Е., Седаш Т. Экологические облигации и депозиты как источник финансирования природоохранных мероприятий // Финансовая жизнь. 2015. - № 3. - С. 58-62, С. 59. 
Известные российские бизнесмены положительно относятся к возможности инвестирования в зеленые облигации. Так, Павел Теплухин - руководитель компании Matrix Capital, «с воодушевлением говорит о новом классе активов («зеленые» рублевые облигации), который должен позволить партнерам участвовать в создании перспективного рынка на десятки миллиардов долларов. По оценке Минприроды, в этом году российский бюджет и компании намерены вложить в экологическую модернизацию промышленных объектов около \$3 млрд О потенциальном интересе к идее экобондов в прошлом году заявляли «Сибур» и «Норильский никель» ${ }^{49}$.

«Норильский Никель» планировал покрыть затраты на инвестиции в зеленые проекты за счет выпуска зеленых облигаций ${ }^{50}$, но выпуск не состоялся. Банк России в лице своего первый зампреда Сергей Швецов в декабре 2017 г. заявил о возможности выпуска зеленых облигаций в российской экономике в 2018 г. : «Первые «зеленые» облигации появятся в России в следующем году, они будут выпущены в формате евробондов. Мы посмотрим на динамику и если увидим высокий спрос на эти бумаги на внутреннем рынке, то уже рассмотрим возможность законодательно закрепить возможность выпуска этих бумаг», - заявил он» ${ }^{51}$.

Эксперты отмечают, что компании фактически выпускают облигации, предназначенные для финансирования экологических проектов (например, в апреле 2017 г. компания ООО «ЭкологияНовосибирск» анонсировала размещение облигаций на 1 млрд руб. для строительства в регионе двух мусороперерабатывающих комплексов ${ }^{52}$ ), но данные бумаги не прошли процедуру сертификации на соответствие Принципам зеленых облигаций.

${ }^{49}$ Вержбицкий А. Матрица Теплухина. Бывший партнер «Тройки Диалог» создает бизнес по управлению активами. 09.11.2017. // Интернет сайт Forbs: http://www.forbes.ru/finansy-i-investicii/351993-matrica-tepluhina-byvshiy-partnertroyki-dialog-sozdaet-biznes-po.

${ }^{50} \mathrm{http}: / / \mathrm{www} . e c o i n d u s t r y . r u /$ news/company/view/45480.html.

${ }^{51}$ TACC: //http://tass.ru/ekonomika/4823713.

52 Цит. по: Гутборг М., Храплива Ю, Володин С. «Зеленые облигации»как новый финансовый инструмент и перспективы их внедрения в России // Валютное регулирование. Валютный контроль. - 2017. - № 9. - С. 44-52, с. 51. 
Первый выпуск «зеленых» облигаций в России состоялся 19 декабря 2018 г., их разместила на Московской бирже компания «Ресурсосбережение XМАО», номинальная стоимость облигаций составляет 1,1 млрд руб., доходность размещения составила 9,76 \%, купон облигаций привязан к инфляции и ключевой ставке Банка России ${ }^{53}$. Выпущенные облигации, согласно заключению рейтингового агентства Rating-Agentur Expert RA, соответствуют Принципам «зеленых» облизаций (Green Bond Principles 2018), разработанными Международной ассоциацией рынков капитала (ICMA). Средства от размещения облигаций, как отмечает компания БКС, «будут направлены на финансирование концессионного проекта создания комплексного межмуниципального полигона для размещения, обезвреживания и обработки ТКО для городов Нефтеюганска, Пыть-Яха и поселений Нефтеюганского района» ${ }^{54}$.

В 2019 г. Московская биржа при поддержке Минэкономразвития создает сектор устойчивого развития, который будет состоять из трех сегментов: «зеленых» облигаций, «социальных» облигаций и национальных проектов ${ }^{55}$. С связи с этим с 12 августа 2019 г. меняются правила листинга биржи. Как отмечает бирже «В сегменты “зеленых" и “социальных” облигаций могут включаться ценные бумаги российских и иностранных эмитентов при соответствии выпуска, эмитента или инвестиционного проекта принципам в области “зеленого"/"социального" финансирования Международной ассоциации рынков капитала (International Capital Market Association, ICMA) либо Международной некоммерческой организации “Инициатива климатических облигаций” (Climate Bonds Initiative, CBI), а также при наличии независимой внешней оценки, подтверждающей соблюде-

${ }^{53}$ Впервые в России были размещены «зеленые» облигации // https://bcsexpress.ru/novosti-i-analitika/vpervye-v-rossii-byli-razmeshcheny-zelenye-obligatsii.

${ }^{54}$ Впервые в России были размещены «зеленые» облигации // https://bcsexpress.ru/novosti-i-analitika/vpervye-v-rossii-byli-razmeshcheny-zelenye-obligatsii.

${ }_{55}$ Московская биржа создает Сектор устойчивого развития. при поддержке Минэкономразвития РФ. 05.08.2019. Сайт Московской биржи // https:// www.moex.com/n24553/?nt=106. 
ние указанных принципов» ${ }^{56}$. Биржа информирует, что «в сегмент национальных проектов могут включаться облигации российских и иностранных эмитентов при соответствии выпуска, эмитента или инвестиционного проекта задачам и результатам национальных проектов “Экология”, “Демография”, “Здравоохранение", федеральных проектов, в том числе "Внедрение наилучших доступных технологий”, а также при наличии решения органов или должностных лиц государственной власти, межведомственных комиссий о соответствии задачам и результатам одного из проектов, указанных в Правилах листинга» ${ }^{57}$.

Государство планирует поддерживать и стимулировать «зеленые» проекты, для чего разрабатываются налоговые льготы и условия поддержки Банка России для инвесторов путем предоставления специальных условий резервирования. В мае 2019 г. Правительство РФ уже приняло Постановление о правилах предоставления субсидий на выплату купонного дохода в размере 70 \% эмитентам облигаций, выпущенных в рамках реализации инвестиционных проектов по внедрению наилучших доступных технологий ${ }^{58}$. Субсидию смогут получить проекты, отвечающие определенным требованиям и прошедшие предварительный отбор, который будет проводиться не чаще двух раз в год. Реализация проектов должна способствовать «поэтапному достижению технологических норм допустимых выбросов и сбросов высокотоксичных веществ и веществ, обла-

${ }^{56}$ Московская биржа создает Сектор устойчивого развития. при поддержке Минэкономразвития РФ. 05.08.2019. Сайт Московской биржи // https:// www.moex.com/n24553/?nt=106.

${ }^{57}$ Московская биржа создает Сектор устойчивого развития. при поддержке Минэкономразвития РФ. 05.08.2019. Сайт Московской биржи // https:// www.moex.com/n24553/?nt=106.

${ }^{58}$ Правила предоставления субсидий из Федерального бюджета Российским организациям на возмещение затратна выплату купонного дохода по облигациям, выпущенным в рамках реализации инвестиционных проектов по внедрению наилучших доступных технологий. Постановление Правительства РФ № 541 от 30.04.2019. Сайт судебных о нормативных актов РФ // https:/sudact.ru/law/ postanovlenie-pravitelstva-rf-ot-30042019-n-541/pravila-predostavleniia-subsidii-izfederalnogo/. 
дающих канцерогенными и мутагенными свойствами» ${ }^{59}$. При этом общая сумма выпуска облигаций не может превышать 30 млрд рублей. Постановление направлено на стимулирование и поддержку российских производителей и при использовании российского оборудования будет субсидироваться $90 \%$ расходов компании на выплату купонного дохода. Компании, претендующие на получение субсидии, не должны иметь налоговой задолженности, находиться в процессе реструктуризации или банкротства. Иностранные компании и компании с более чем 50 \% долей иностранного участия или размещенные на территории стран с льготным налоговым режимом или в офшорных зонах, не смогут получить субсидию.

Данные меры направлены на стимулирование развития «зеленого» финансирования в российской экономике и поддержку экологических проектов. Запланирована реализация следующих мер: модернизировать и перевести на принципы наилучших доступных технологий 300 российских предприятий, наносящих наибольший ущерб экологии России. Программа начнется уже в 2019 г., срок ее реализации - до конца 2029 г., а до 2031 г. охватит уже 7000 предприятий. Объем средств на программу -8 трлн руб. «Для предприятий - участников проекта внедрения НДТ предусмотрены меры господдержки - это льготы по оплате за негативное воздействие на окружающую среду, инвестиционные льготные кредиты, льготные кредиты и займы на приобретение оборудования. Также предусмотрено субсидирование процентных ставок по инвестиционным кредитам, ставки “купонного дохода” инвесторам по “зеленым облигациям”, выпущенным в рамках реализации природоохранных проектов. Объем средств на субсидии по проекту НДТ планируется на уровне 0,3 млрд рублей в 2019 году, 3 млрд руб. в 2020 г. и 6 млрд рублей - в 2021 году» ${ }^{60}$. Данные меры реализуются в рамках национального проекта «Экология».

${ }^{59}$ Кабмин утвердил правила субсидирования «зеленых облигаций» 05.05.2019. Сайт агентства ТАСC // https://tass.ru/nacionalnye-proekty/6404985.

${ }^{60}$ Кабмин утвердил правила субсидирования «зеленых облигаций» 05.05.2019. Сайт агентства ТАСC // https://tass.ru/nacionalnye-proekty/6404985. 


\section{3. Оценка рисков \\ эколого-экономического состояния региона: анализ российских регионов}

Считаем, что при выпуске инструментов финансирования экологических проектов (например, «зеленых» облигаций) целесообразно учитывать на какой территории реализуются проекты и для обоснования рейтинга ценных бумаг рассчитывать риски эколого-экономического состояния регионов. В качестве меры рисков предлагаем учитывать рейтинг «эколого-экономической привлекательности» регионов, расчет которого предложен в главе 2 данной работы (формула 9). Значение данного показателя определяет рейтинг ценных бумаг и характеризует риск инвестирования в региональные экологическое проекты. Соотношение значение рейтинга «эколого-экономической привлекательности» регионов и рейтинга ценных бумаг представлено в таблице 25.

Авторами проведено исследование 80 российских регионов и определен рейтинг «эколого-экономического риска» регионов. В качестве исходных данных использовались показатели Росстата по регионам за 2010-2016 гг. : выбросы загрязняющих веществ от стационарных источников, тыс. тонн; индексы физического объема валового регионального продукта на душу населения; численность населения, тыс. чел.

Таблицча 25

Шкала рейтинга «зеленых» источников финансирования ${ }^{61}$

\begin{tabular}{|c|c|l|}
\hline $\begin{array}{c}\text { Рейтинг «эколого- } \\
\text { экономической при- } \\
\text { влекательности» ре- } \\
\text { гионов }\end{array}$ & $\begin{array}{c}\text { Рейтинговая } \\
\text { шкала «зеле- } \\
\text { ных» ценных } \\
\text { бумаг }\end{array}$ & \multicolumn{1}{|c|}{$\begin{array}{c}\text { Характеристика } \\
\text { рейтинговой шкалы }\end{array}$} \\
\hline$[1 \div 2[$ & $\mathrm{A}+$ & $\begin{array}{l}\text { Низкий уровень риска. Регион ха- } \\
\text { рактеризуется высоким потенциа- } \\
\end{array}$ \\
& $\begin{array}{l}\text { лом экономического развития при } \\
\text { снижающемся уровне экологиче- } \\
\text { ской нагрузки }\end{array}$ \\
\hline
\end{tabular}

61 За основу взята национальная шкала рейтинга облигаций рейтингового агентства «Эксперт РА» // https://raexpert.ru/ratings/corporatebond/ratingscale/. 
Окончание таблицы 25

\begin{tabular}{|c|c|l|}
\hline $\begin{array}{c}\text { Рейтинг «эколого- } \\
\text { экономической при- } \\
\text { влекательности»ре- } \\
\text { гионов }\end{array}$ & $\begin{array}{c}\text { Рейтинговая } \\
\text { шкала «зеле- } \\
\text { ных» ценных } \\
\text { бумаг }\end{array}$ & \multicolumn{1}{|c|}{$\begin{array}{c}\text { Характеристика } \\
\text { рейтинговой шкалы }\end{array}$} \\
\hline$[2 \div 3[$ & $\mathrm{A}$ & $\begin{array}{l}\text { Удовлетворительный уровень рис- } \\
\text { ка. Характерно экономическое раз- } \\
\text { витие региона при меньшем росте } \\
\text { экологической нагрузки }\end{array}$ \\
\hline$[3 \div 4[$ & $\mathrm{B}+$ & $\begin{array}{l}\text { Приемлемый уровень экологиче- } \\
\text { ского риска. Регион характеризует- } \\
\text { ся снижением экономического раз- } \\
\text { вития. Но и антропогенная нагрузка } \\
\text { на окружающую среду снижается }\end{array}$ \\
\hline$[4 \div 5[$ & $\mathrm{B}$ & $\begin{array}{l}\text { Высокий уровень риска. Экономиче- } \\
\text { ский рост в регионе отсутствует при } \\
\text { снижении экологической нагрузки }\end{array}$ \\
\hline$[5 \div 6]$ & $\mathrm{C}$ & $\begin{array}{l}\text { Очень высокий уровень риска. } \\
\text { Снижение экономический показа- } \\
\text { телей сопровождается ростом эко- } \\
\text { логической нагрузки в регионе }\end{array}$ \\
\hline
\end{tabular}

Примечание. Источник: составлено автором.

Результаты исследования российских регионов по уровню эколого-экономического риска приведены в приложениях В и Г, обобщенные данные - таблицах 26 и 27. Регионы в таблице 26 проранжированы по возрастанию риска. Так наименьший рейтинг, характеризующий меньшее значение риска, имеет Липецкая область $(1,14)$, а наибольший (максимальный риск) - Кемеровская область (4,71).

Сравнивая данные анализа с исследованием, проведенным коллективом ученых (Бобылев С.Н. и др., 2012) ${ }^{62}$ по расчету эколого-экономического рейтинга регионов на основе показателя «скорректированные чистые накопления», отметим, что лидеры и аутсайдеры рейтинга не совпадают, за исключением Кемеровской области. По нашему мнению, разница в результатах вызвана следующими обстоятельствами:

- расчет эколого-экономического рейтинга регионов проводился за один период (2012 г.), в то время как рейтинг эколого-

${ }^{62}$ Бобылев, С.Н., Минаков В.С. и др. Эколого-экономический индекс регионов РФ. Методика и показатели для расчета. М.: WWF России, РИА Новости, 2012. - 152 с. 
экономического риска регионов отражает данные за длительный период (пять периодов), что позволяет учесть инерционность экономических процессов;

- эколого-экономический рейтинг не позволяет дать однозначную оценку эффективности управленческих решений относительно реализации эколого-экономической политики региона: так, добывающие регионы с низким показателем рейтинга являются донорами бюджетов других территорий, при этом на собственной территории может не обеспечиваться воспроизводство природных ресурсов.

Исследование показало, что почти половина российских регионов имеют рейтинг В+ $(46,24 \%)$ и относятся к приемлемому уровню эколого-экономического риска. Низкий уровень риска имеют 11,25 \% регионов, удовлетворительный - 31,25 \%, высокий уровень риска - 11,25 \%, в последнюю группу с очень высоким уровнем риска не попал ни один регион. Рассматривая регионы с низким уровнем эколого-экономического риска (рейтинг А+), следует отметить, что из 9 регионов в группе восемь принадлежат к промышленным регионам и только один (Курская область) входит в группу аграрно-промышленных регионов. Среди 9 регионов в группе с высоким уровнем риска (рейтинг В) семь относятся в аграрно-промышленным регионам и два (Приморский край и Кемеровская область) - в группу промышленных регионов. Оценивая такое распределение регионов, следует подчеркнуть, что сельское хозяйство оказывает большое влияние на состояние окружающей среды: «более 75 \% пресной воды используется для нужд сельского хозяйства, включая животноводство, около 25 \% участков суши занято под пастбища, производство продовольственных растительных культур выросло с 1970 г. на $300 \%$ \% ${ }^{63}$. Деление регионов на экспортно-ориентированные, промышленные и аграрно-промышленные приведено в работе Бобылева С.Н. и др. ${ }^{64}$

${ }^{63}$ Рождественская, Я. Человечество поставило под угрозу миллион других видов. Коммерсантъ, 06.may.2019.

${ }^{64}$ Бобылев, С.Н., Минаков В.С. и др. Эколого-экономический индекс регионов РФ. Методика и показатели для расчета. М.: WWF России, РИА Новости, 2012. - 152 с., с. 34-35. 
Таблица 26

\section{Ранжирование регионов \\ по уровню «эколого-экономического риска»}

\begin{tabular}{|c|c|}
\hline $\begin{array}{c}\text { Рейтинг эколого- } \\
\text { экономического } \\
\text { риска регионов }\end{array}$ & Регионы \\
\hline $\mathrm{A}+$ & $\begin{array}{l}\text { Липецкая область, Тульская область, Архангельская об- } \\
\text { ласть, Белгородская область, Вологодская область, Ир- } \\
\text { кутская область, Курская область, Новгородская об- } \\
\text { ласть, Свердловская область }\end{array}$ \\
\hline A & $\begin{array}{l}\text { Ульяновская область, Челябинская область, Республика Са- } \\
\text { ха (Якугия), Республика Мордовия, Мурманская область } \\
\text { Красноярский край, Удмуртская Республика, Саратов- } \\
\text { ская область, Республика Тыва, Хабаровский край, Вла- } \\
\text { димирская область, Чеченская Республика, Ростовская } \\
\text { область, Чувашская Республика - Чувашия, Воронеж- } \\
\text { ская область, Московская область, Брянская область, } \\
\text { Ярославская область, Республика Марий Эл, Ленинград- } \\
\text { ская область, Сахалинская область, Республика Калмы- } \\
\text { кия, Орловская область, Тверская область, Новосибир- } \\
\text { ская область }\end{array}$ \\
\hline $\mathrm{B}+$ & $\begin{array}{l}\text { Костромская область, Город Москва, Республика Та- } \\
\text { тарстан (Татарстан), Псковская область, Самарская об- } \\
\text { ласть, Томская область, Магаданская область, Иванов- } \\
\text { ская область } \\
\text { Калининградская область, Республика Хакасия, Кара- } \\
\text { чаево-Черкесская Республика, Камчатский край, Астра- } \\
\text { ханская область, Курганская область, Республика Каре- } \\
\text { лия, Республика Коми, Нижегородская область, Респуб- } \\
\text { лика Башкортостан, Тамбовская область, Омская об- } \\
\text { ласть, Пермский край, Республика Северная Осетия- } \\
\text { Алания, Республика Алтай, Чукотский автономный ок- } \\
\text { руг, Калужская область, Кировская область, Кабардино- } \\
\text { Балкарская Республика, Волгоградская область, Смо- } \\
\text { ленская область, Город Санкт-Петербург, Забайкальский } \\
\text { край, Республика Бурятия, Республика Дагестан, Став- } \\
\text { ропольский край, Тюменская область, Амурская об- } \\
\text { ласть, Рязанская область }\end{array}$ \\
\hline B & $\begin{array}{l}\text { Республика Адыгея, Алтайский край, Приморский Край, } \\
\text { Республика Ингушетия, Краснодарский край, Пензен- } \\
\text { ская область, Оренбургская область, Еврейская авто- } \\
\text { номная область, Кемеровская область }\end{array}$ \\
\hline
\end{tabular}

Примечание. Источник: расчеты авторов. 
Лидером рейтинга является Липецкая область, а аутсайдером рейтинга оказалась Кемеровская область. Сравнение регионов приведено в таблице 27. Декаплинг-анализ показал, что Липецкая область на протяжении анализируемого периода в 83,33 \% имеет снижение выбросов загрязняющих веществ от стационарных источников на душу населения при росте ВРП на душу населения во всех периодах анализа, что характеризует абсолютный эффект декаплинга в 83,33 \% случаях наблюдений. Данная ситуация является наиболее благоприятной с точки зрения эколого-экономического состояния региона и характеризуется снижением экологической нагрузки в регионе при одновременном экономическом росте. В Кемеровской области 50 \% наблюдений показывают рост выбросов загрязняющих веществ от стационарных источников на душу населения, при этом ВПР на душу населения снижается в $66,67 \%$ случаях. Декаплинг-анализ показал, что область в половине из анализируемых периодах находится в наихудшем секторе, когда рост нагрузки на экологию региона сопровождается ухудшением экономической ситуации.

Таблицча 27

\section{Характеристика эффекта декаплинга}

\begin{tabular}{|c|c|c|c|c|c|c|c|}
\hline Год & 2010 & 2011 & 2012 & 2013 & 2014 & 2015 & 2016 \\
\hline \multicolumn{8}{|c|}{ Липецкая область, Reea = 1,14 } \\
\hline $\mathrm{R}_{1}$,тыс. тонн & 367,630 & 344,910 & 338,750 & 346,680 & 330,000 & 327,690 & 320,360 \\
\hline R1 т/чел & 0,312 & 0,294 & 0,291 & 0,298 & 0,284 & 0,283 & 0,277 \\
\hline$\Delta \mathrm{R}_{1}$, отн. ед. & - & & $-0,013$ & 0,027 & & $-0,005$ & $-0,021$ \\
\hline ТY, отн. ед & 1,044 & 53 & 1,022 & 1,037 & 1,053 & 1,012 & 1,017 \\
\hline$\triangle \mathrm{TY}, \mathrm{\text {оTH}}$ & - & 0,053 & 0,022 & 0,037 & 0,053 & 0,012 & 0,017 \\
\hline Сек & - & 1 & 1 & 2 & 1 & 1 & 4 \\
\hline \multicolumn{8}{|c|}{ Кемеровская область, Reea = 4,71 } \\
\hline $\mathrm{R}_{1, \mathrm{~T}}$ & 1410,650 & 1390,030 & 1360,360 & 1356,300 & 1331,690 & 1344,460 & 1349,480 \\
\hline R1 т/чел & 0,509 & 0,503 & 0,494 & 0,495 & 0,487 & 0,493 & 0,496 \\
\hline$\Delta \mathrm{R}_{1}$, отн. & - & $-0,010$ & $-0,018$ & 0,000 & $-0,015$ & 0,013 & 0,006 \\
\hline ТY, отн. ед & 1,030 & 1,027 & 0,961 & 0,963 & 1,024 & 0,993 & 0,973 \\
\hline$\Delta \mathrm{TY}, \mathrm{\text {oT }}$ & - & 0,027 & $-0,039$ & $-0,037$ & 0,024 & $-0,007$ & $-0,027$ \\
\hline Сектор (по $\left.\mathrm{R}_{1}\right)$ & - & 1 & 5 & 6 & 1 & 6 & 6 \\
\hline
\end{tabular}

Примечание: ТY - индекс физического объема ВРП на душу населения, отн. ед.; $\Delta$ TY - темп прироста физического объема ВРП на душу населения отн. 
ед.; R1 - выбросы загрязняющих веществ от стационарных источников, тыс. тонн; R1 т/чел. - выбросы загрязняющих веществ от стационарных источников на душу населения; $\Delta \mathrm{R} 1$ - темп прироста R1 на душу населения, отн. ед.; сектор (по R1) - сектор, характеризующий эффект декаплинга по модели декаплинганализа; Reea - рейтинг эколого-экономической привлекательности региона.

Источник: расчеты авторов по данным : единая межведомственная информационно-статистическая база // https:/fedstat.ru/, сайты ТОГС // http:// www.gks.ru/wps/wcm/connect/rosstat_main/rosstat/ru/about/territorial/site/.

Выводы. Сложности и перспективы развития рынка зеленых облигаций в российской экономике проявляются в следующем:

- средний объем эмиссии облигаций - от 1млрд долл., в то время как проекты зеленых инвестиций требуют меньшие суммы - от 30 тыс. до 11 млн долл., что делает экономически неэффективным эмиссию ценных бумаг под конкретный проект, поэтому эмитенты прибегают к выпуску секьюритизированных ценных бумаг. Это требует развития отлаженных механизмов секьюритизации и рынка секьюритизированных финансовых активов;

- для выпуска зеленых облигаций необходима процедура соответствия Принципам зеленых облигаций, раскрытие информации, составление дополнительной отчетности, что увеличивает затраты эмитента; необходимо отметить отсутствие достаточной нормативно-правовой базы для внедрения данных инструментов в российскую экономку в соответствии с международными стандартами;

- зеленые облигации находятся на начальной стадии своего развития не только в России, но и в мире (12 лет рынку зеленых финансовых инструментов), с связи с чем возможна неправильная оценка риска данных бумаг;

- рынок зеленого финансирования развивается быстрыми темпами: расширяется спектр финансовых инструментов: появились и находят своего инвестора такие инструменты как «голубые» облигации, «зеленые» секьюритизированные кредиты; возникают новые институциональные фонды, поддерживающие не только крупные, но и средние компании;

- перспективы развития рынка хорошие, о чем говорит быстрый рост объемов рынка, присоединение к данному рынку компаний и государственных органов не только развитых, но и разви- 
вающихся стран (Китай, Индия), осознание важности экологических проектов для страновых экономик и для мира в целом всеми стейкхолдерами. Поэтому у российского рынка хорошие шансы для внедрения зеленых финансовых инструментов и развития российского сегмента зеленых финансов;

- для оценки эколого-экономического риска инвестирования в «зеленые» ценные бумаги предложена шкала рейтинга ценных бумаг на основе значений рейтинга «эколого-экономического риска» регионов и рассчитан рейтинг для российских регионов. 


\section{ЗАКЛЮЧЕНИЕ}

На основе проведенного исследования можно сделать следующие выводы и дать практические рекомендации по оценке эколого-экономического состояния региона:

Эколого-экономическое развитие региона обеспечивается качеством окружающей среды в долгосрочной перспективе и определяется степенью воздействия человеком на окружающую среду. Понимание данного принципа является основой концепции устойчивого роста и теории «зеленого роста» которая в настоящее время становится базисом для принятия различных управленческих решений как на уровне государства, так и на уровне отдельных компаний.

Теоретической и методологической основой исследования явилась концепция устойчивого экономического роста и теория «зеленой» экономики. В резолюции, принятой Генеральной ассамблеей ООН 25 сентября 2015 г. «Повестка дня в области устойчивого развития на период до 2030 года» поставлены 17 целей и 169 задач в области устойчивого развития. В документе подчеркивается важность не только экономического развития, но и экологического устойчивого развития. Постановка целей и задач требует разработки индикаторов устойчивого развития для мониторинга и оценки эффективности управленческих решений.

Оценить эффект от внедрения инструментов и механизмов стимулирования «зеленой» экономики и определить степень эколого-экономической привлекательности региона, по мнению авторов, возможно с помощью индикатора «индекс декаплинга». Эффект декаплинга характеризуется «расщеплением», «разъединением» темпов прироста показателей экономического роста (ВВП, ВРП) и темпов прироста потребления природных ресурсов и отходов производства и потребления. Наличие эффекта «декаплинга» является необходимым условием развития «зеленой» экономики. 
Для анализа эффективности эколого-экономического состояния регионов в работе использован декаплинг-метод, основанный на расчете индекса декаплинга, который позволяет оценить наличие эффекта «декаплинга», а именно - экстенсивность или интенсивность развития экономики по отношению использованию природных ресурсов и условий окружающей среды.

Индекс декаплинга рассчитывается как относительное изменение (коэффициент роста) потребляемого ресурса или выброса загрязнения за определенный период к относительному изменению результирующего показателя (как правило ВВП, ВРП, т. п.) за аналогичный период. Индекс декаплинга, рассчитываемый таким образом дает возможность оценить наличие эффекта «декаплинга», но не показывает, является ли этот эффект абсолютным или относительным. Также отсутствует возможность более глубоких выводов об эколого-экономическом положении региона.

Авторами предлагается усовершенствованная модель анализа эффекта «декаплинга», позволяющая устранить эти недостатки. Модель основана на сопоставлении коэффициентов прироста потребляемых ресурсов и/или загрязнений и показателями экономического роста. Модель позволяет выделить шесть секторов, характеризующих различную степень эффективности эколого-экономического состояния региона. При этом внутри секторов можно выделить различные соотношения экономической и экологической ситуаций в регионе.

Проведен анализ эффекта «декаплинга» на примере 80 российских регионов по усовершенствованной модели декаплинг-анализа по показателю «выбросы загрязняющих веществ от стационарных источников» Рассчитан рейтинг эколого-экономического риска 80 российских регионов на основе предложенной модели декаплинг-анализа.

Таким образом, основные научные и практические результаты заключаются в том, что авторами разработаны 1) модель декаплинг-анализа с выделением шести качественно различных секторов, характеризующих эколого-экономическую ситуацию в регионах и 2) проведен расчет рейтинга эколого-экономического привлекательности регионов. Предложенные модели и показатели целесообразно применять для экологического мониторинга и мониторинга эколого-экономического развития регионов. 


\section{СПИСОК ЛИТЕРАТУРЫ}

1. Акулов А.О. Эффект декаплинга в индустриальном регионе (на примере Кемеровской области) // Экономические и социальные перемены: факты, тенденции, прогноз. - 2013. - № 4 (28). - С. 177-185.

2. Аналитический доклад «Риски реализации Парижского климатического соглашения для экономики и национальной безопасности» / Институг проблем естественных монополий. - Москва, 2016, 114 с.

3. Аналитический портал «Гуманитарные технологии» // https:// gtmarket.ru/news/2017/03/20/7316.

4. Аникин А., Аникина И.Д. «Зеленые облигации» как финансовые инструменты реализации инвестиционных экологических проектов: возможность применения в российской экономике: параграф в колл. монографии: Научно-практические аспекты финансовой безопасности (на уровне государства, региона, организации и личности): коллективная монография ; Федер. гос. авт. образоват. учреждение высш. проф. образования «Волгогр. гос. ун-т». - Курск : Изд-во ЗАО «Университетская книга», 2018. - 244 с., с. 54-65.

5. Бобров А.Л., Папенов К.В., Направления социально-эколого-экономического развития России // Вест. Моск. ун-та. Сер. 6. Экономика. 2013. №4. C. 101-118.

6. Бобылев С.Н. Экологические приоритеты для России // https:// ppt-online.org/355370.

7. Богачева О.В., Смородинов О.В. «Зеленые облигации как важнейший инструмент финансирования «зеленых» проектов // Финансовый журнал. - 2016. - № 2. - С. 70-81.

8. Богачева О.В., Смородинов О.В. Государственные меры по организации и развитию рынка «зеленых» облигаций // Финансовый журнал. -2016 . - № 3. - С. 55-65.

9. Брошюра ООН «Меры по борьбе с изменением климата: значение для бизнеса» // https://www.un.org/sustainabledevelopment/ru/climate-change/.

10. Бюджетный кодекс Российской Федерации» от 31.07.1998 № 145-Ф3 (ред. От 03.08.2018) http://www.consultant.ru/document/cons_doc_LAW_19702/ 1b6959f23cc516d0e11ddc2e213ca2dca83560df/.

11. Варавин Е. В., Козлова М. В. Оценка развития зеленой экономики в регионе. На примере Республики Казахстан // Экономика региона. 2018. - Т. 14, вып. 4. - С. 1282-1297. 
12. Вержбицкий А. Матрица Теплухина. Бывший партнер «Тройки Диалог» создает бизнес по управлению активами. 09.11.2017. // Интернет сайт Forbs: http://www.forbes.ru/finansy-i-investicii/351993-matrica-tepluhinabyvshiy-partner-troyki-dialog-sozdaet-biznes-po.

13. Вестник отделения наук о Земле РАН // https://onznews.wdcb.ru/ images/news16/160402_f03.jpg.

14. Вестник отделения наук о Земле РАН // https://onznews.wdcb.ru/ images/news $16 /$.

15. Вестник отделения наук о Земле РАН // https://onznews.wdcb.ru/ images/news16/info_160307.html.

16. Глазунова Н. Волгоградские предприятия инвестируют в экологию 30 млрд руб. Комсомольская правда-Волгоград, 16.07.2018.

17. Глобальный зеленый новый курс. Доклад, март 2009 г. Издано Программой $\mathrm{OOH}$ по окружающей среде в рамках Инициативы по зеленой экономике. // http://www.unepcom.ru/images/greeneconomy/ greennewdeal.pdf.

18. Государственная программа Российской Федерации «Экономическое развитие и инновационная экономика» Утверждена постановлением Правительства Российской Федерации от 15.04.2014 г. № 316.

19. Гутборг М., Храплива Ю, Володин С. «Зеленые облигации» как новый финансовый инструмент и перспективы их внедрения в России // Валютное регулирование. Валютный контроль. - 2017. - № 9. - С. 44-52.

20. Давыдова А. Россия согласилась на Парижский климат. Коммерсантъ № 173, 24.09.2019.

21. Давыдова А. Россия согласилась на Парижский климат. Коммерсанть № 173, 24.09.2019.

22. Доклад «О состоянии окружающей среды Волгоградской области в 2015 году»/ Ред. Колл.: В.Е. Сазонов [ и др.]; комитет природных ресурсов и экологии Волгоградской области. - Волгоград: «СМОТРИ», 2016. -300 с., с. $129-146$.

23. Доклад «О состоянии окружающей среды Волгоградской области в 2018 году» - ред. кол.: В.Е. Сазонов [и др.]; комитет природных ресурсов, лесного хозяйства и экологии Волгоградской области. - Ижевск: ООО «Принт», 2019. - 300 c., https://oblkompriroda.volgograd.ru/upload/iblock/ 3cc/Doklad-2018.pdf.

24. Доклад о ходе реализации государственной программы Волгоградской области «Охрана окружающей среды на территории Волгоградской области» за 2018 г. Режим доступа: https:/oblkompriroda.volgograd.ru/ current-activity/programs/results/. 
25. Доклад: Индексы и индикаторы человеческого развития. Обновленные статистические данные 2018 // Опубликовано для Программы развития Организации Объединенных Наций (ПРООН). 122 с. // http:// hdr.undp.org/en/2018-update/download, hdr.undp.org/en/2018-update.

26. Дубовик О.Л., Аверина К.Н. Значение Парижского соглашения для охраны климата: крупномасштабные планы и проблемы с их реализацией // Международное право и международные организации. - 2018. № 4 // Система КонсультантПлюс: Юридическая пресса.

27. Думнов А.Д., Борискин Д.А., Рыбальский Н.Г. О некоторых методах макростатистического анализа природопользования и охраны окружающей среды // Век глобализации. - 2017 - № 2. - С. 37-50.

28. ЕвроХим награжден золотой медалью за достижения в сфере охраны труда и экологии. Комсомольская правда-Волгоград, 22.11.2018.

29. Единая межведомственная информационно-статистическая база (ЕМИС). Режим доступа: https://fedstat.ru/.

30. Единая межведомственная информационно-статистическая база // https://fedstat.ru/.

31. Ежемесячный обзор «Устойчивое развитие и зеленые инвестиции», 2019. - № 6. - 17 с. // Национальная ассоциация концессионеров и долгосрочных инвесторов в инфраструктуру ((НАКДИ) // www.investinfra.ru.

32. Ежемесячный обзор «Устойчивое развитие и зеленые инвестиции», 2019. - № 5. - 19 с. // Национальная ассоциация концессионеров и долгосрочных инвесторов в инфраструктуру ((НАКДИ) // www.investinfra.ru.

33. Зеленые облигации - растет рынок экологических финансовых инструментов. // http://eenergy.media/2017/10/03/zelenye-obligatsii-rastetrynok-ekologicheskih-finansovyh-instrumentov/.

34. Зеленые облигации - растет рынок экологических финансовых инструментов. // http://eenery.media/2017/10/03/zelenye-obligatsii-rastetrynok-ekologicheskih-finansovyh-instrumentov/.

35. Зеленые облигации на Московской бирже. Б. Николаев. Независимая газета. 14.01.2019// http://www.ng.ru/ng_energiya/2019-01-14/ 15_7481_energyl0.html.

36. Зеленые облигации на Московской бирже. Б. Николаев. Независимая газета. 14.01.2019// http://www.ng.ru/ng_energiya/2019-01-14/ 15_7481_energyl0.html.

37. Индекс развития человеческого потенциала. Гуманитарная энциклопедия: Исследования [Электронный ресурс] // Центр гуманитарных технологий, 2006-2019 (последняя редакция: 23.04.2019). URL: https:/gtmarket.ru/ ratings/human-development-index/human-development-index-info. 
38. Индексы и индикаторы человеческого развития: Обновленные статистические данные 2018. Программа развития Организации Объединенных Наций (ПРООН), 2018. - 122 с.

39. Интернет сайт Lenta.ru https://lenta.ru/news/2013/12/02/bonds//.

40. Информационно-консалтинговая компания Enerdata https:// yearbook.enerdata.ru/renewables/renewable-in-electricity-productionshare.html.

41. Информационные материалы третьей международной конференции по финансированию развития // http://www.un.org/ sustainabledevelopment/wp-content/uploads/2015/07/FFD-Press-KitRussian-ONLINE.pdf.

42. Информационный портал «Будущее России. Национальные проекты» // https://futurerussia.gov.ru/nacionalnye-proekty/srocno-medvedevpodpisal-postanovlenie-svazannoe-s-prinatiem-rf-parizskogo-soglasenia-poklimatu.

43. Информационный портал «Будущее России. Национальные проекты». Режим доступа: https://futurerussia.gov.ru/nacionalnye-proekty/ srocno-medvedev-podpisal-postanovlenie-svazannoe-s-prinatiem-rfparizskogo-soglasenia-po-klimatu.

44. Каменева Е., Седаш Т. Финансовый инструментарий повышения энергоэффективности экономики России. // Менеджмент и бизнес-администрирование. - 2015. - № 4. - С. 93-102.

45. Киотский протокол к Рамочной конвенции Организации Объединенных Наций об изменении климата. Официальный сайт ООН // https:/ /www.un.org/ru/documents/decl_conv/conventions/kyoto.shtml.

46. Кириллов С.Н., Пакина А.А., Тульская Н.И. Оценка устойчивости развития на региональном уровне: пример Республики Татарстан // Вестник ВолГУ. Серия 3, Экономика, Экология. - 2017. - № 4. - С. 127-137.

47. Краткое содержание и основные положения доклада «Риски реализации Парижского климатического соглашения для экономики и национальной безопасности» / Институт проблем естественных монополий. Москва, 2016, 22 с.

48. Медоуз Д. Х., Медоуз Д.Л., Рэндерс Й., Беренс III В. Пределы роста / пер. с англ. - М. : Изд-во МГУ. - 1991. - 207 с.

49. Международное энергетическое агентство // https:// webstore.iea.org/co2-emissions-from-fuel-combustion-2018-highlights.

50. На саммите G20 по инициативе Китая впервые обсудят «зеленые финансы» 31.08.2016. Сайт CNTV// http://russian.cctv.com/2016/08/31/ VIDE7XrmxKkui1JtQbWaPcDz160831.shtml. 
51. Необходимая финансовая система. Отчет об исследовании ЮНЕП «Развитие финансовой системы с учетом устойчивого развития». Октябрь 2015 // http://unepinquiry.org/wp-content/uploads/2015/10/ The_Financial_System_We_Need_RU.pdf.

52. Об утверждении плана основных мероприятий, проводимых в Волгоградской области в рамках Года экологии в Российской Федерации в 2017 году. Постановление Губернатора Волгоградской области от 26.12.2016 № 998.

53. Основы государственной политики в области экологического развития Российской Федерации на период до 2030 года (утв. Президентом РФ 30.04.2012). Режим доступа: http://www.consultant.ru/document/ cons_doc_LAW_129117/.

54. Официальный сайт SDSN :http://unsdsn.org/.

55. Официальный сайт The Earth Institute: https:// www.earth.columbia.edu/.

56. Официальный сайт Глобального экологического фонда https:// www.thegef.org/.

57. Официальный сайт группы Всемирного банка http:// www.worldbank.org/.

58. Официальный сайт Европейского инвестиционного банка http:/ /www.eib.org/en/.

59. Официальный сайт Зеленого климатического фонда https:// www.greenclimate.fund/home.

60. Официальный сайт Интерфакс https://www.interfax.ru/world/ 573661.

61. Официальный сайт Комитета природных ресурсов, лесного хозяйства и экологии Волгоградской области // http://oblkompriroda.volgograd.ru/.

62. Официальный сайт Минприроды РФ // http://www.mnr.gov.ru/ press/news/minprirody_rossii_podgotovilo_i_vneslo_v_pravitelstvo_rf_ predlozheniya_s_obosnovaniem_tselesoobrazno/.

63. Официальный сайт ООН// https://www.un.org/ru/climatechange/.

64. Официальный сайт ОOH // https://www.un.org/ru/climatechange/ .un-climate-summit-2019.shtml.

65. Официальный сайт $\mathrm{OOH} / /$ https://www.un.org/sustainabledevelopment/ $\mathrm{ru} /$ climate-change/.

66. Официальный сайт Правительства Российской Федерации http:/ $/ \mathrm{kremlin} . \mathrm{ru} /$ events/president/news/57425.

67. Официальный сайт программы Talanoa-Dialogue // https:// talanoadialogue.com/. 
68. Официальный сайт Рейтингового агентства Expert // https://ra expert.ru/ratings/corporatebond/ratingscale/.

69. Официальный сайт Росстата: http://www.gks.ru/.

70. Официальный сайт Территориального органа государственной статистики по Волгоградской области http://volgastat.gks.ru/wps/wcm/connect/ rosstat_ts/volgastat/ru/statistics/environment/, http://volgastat.gks.ru/wps/wcm/ connect/rosstat_ts/volgastat/ru/statistics/gr.

71. Парижское соглашение // https://treaties.un.org/doc/Treaties/2016/ 02/20160215\%2006-03\%20PM/Ch_XXVII-7-d.pdf.

72. Парижскому соглашению РСПП не мешает // газета «Коммерсантъ» №13 от 25.01.2019, стр. 2// Официальный сайт газеты «Коммерсантъ»// https://www.kommersant.ru/doc/3862151.

73. Паспорт национального проекта «Экология» (утв. президиумом Совета при Президенте РФ по стратегическому развитию и национальным проектам, протокол от 24.12.2018 № 16). Режим доступа: http:// www.consultant.ru/document/cons_doc_LAW_316096/.

74. Паспорт Национального проекта «Экология». Сайт Минприроды России// http://www.mnr.gov.ru/activity/directions/natsionalnyy_ proekt_ekologiya/.

75. План реализации комплекса мер по совершенствованию государственного регулирования выбросов парниковых газов и подготовки к ратификации Парижского соглашения, принятого 12 декабря 2015 г. 21-й сессией Конференции Сторон Рамочной конвенции Организации Объединенных Наций об изменении климата. Распоряжение Правительства Российской Федерации от 3 ноября 2016 г. № 2344-р.

76. Преобразование нашего мира: Повестка дня в области устойчивого развития на период до 2030 года. Резолюция, принятая Генеральной Ассамблеей 25 сентября 2015 года // https://undocs.org/ru/A/RES/70/1.

77. Приказ Минприроды России от 11.10.2018 № 509 «Об утверждении формы декларации о воздействии на окружающую среду и порядка ее заполнения, в том числе в форме электронного документа, подписанного усиленной квалифицированной электронной подписью» (Зарегистрировано в Минюсте России 10.12.2018 № 52926).

78. Приказ Минприроды России от 11.10.2018 № 510 «Об утверждении формы заявки на получение комплексного экологического разрешения и формы комплексного экологического разрешения» (Зарегистрировано в Минюсте России 10.12.2018 № 52927).

79. Приказ Минприроды России от 30.06.2015 № 300 «Об угверждении методических указаний и руководства по количественному опреде- 
лению объема выбросов парниковых газов организациями, осуществляющими хозяйственную и иную деятельность в Российской Федерации» (Зарегистрировано в Минюсте России 15.12.2015 № 40098) // http:// www.consultant.ru/cons/cgi/online.cgi?req $=$ doc\&base $=$ LAW\&n=190838\&fld $=134 \& \mathrm{dst}=1000000001,0 \& \mathrm{rnd}=0.24185131508949387 \# 09545703212195382$.

80. Принципы зеленых облигаций // https://www.icmagroup.org/greensocial-and-sustainability-bonds/green-bond-principles-gbp/.

81. Программа развития ООН: Развитие человеческого потенциала в регионах России в 2013 году. [Электронный ресурс] // Центр гуманитарных технологий. - 17.06.2013. 20:55. URL: https:/gtmarket.ru/news/2013/06/ $17 / 6014$.

82. Проект Федерального закона «О государственном регулировании выбросов парниковых газов и о внесении изменений в отдельные законодательные акты Российской Федерации» // Источник: https:// regulation.gov.ru/projects/List/AdvancedSearch\#kinds $=6 \&$ StartDate $=$ 7.12.2018\&EndDate $=7.12 .2018 \&$ npa $=86521$.

83. Проект Ф3 “О государственном регулировании выбросов и поглощений парниковых газов и о внесении изменений в отдельные законодательные акты Российской Федерации"(подготовлен Минэкономразвития России) (не внесен в ГД ФС РФ, текст по состоянию на 27.03.2019). Режим доступа: http://www.consultant.ru/cons/cgi/online.cgi?req= doc\&base $=$ PRJ\&n $=183113 \# 014268883547042987$.

84. Рамочная конвенция Организации Объединенных Наций об изменении климата. Принята 9 мая 1992 года //https://www.un.org/ru/ documents/decl_conv/conventions/climate_framework_conv.shtml.

85. Рахманкулов Д.Л., Николаева С.В., Латыпова Ф.Н., Вильданов Ф.Ш., Шавшукова С.Ю. Мировые запасы угля и перспективы его использования // Башкирский химический журнал. 2009. Том 16. № 2. С. 21-28.

86. Резолюция, принятая Генеральной ассамблеи ООН 25 сентября 2015 г.// https://undocs.org/ru/A/RES/70/1.

87. РИА Новости. Режим доступа: https://ria.ru/20190923/ 1559005730.html?in=t.

88. РИА Новости. Режим доступа: https://ria.ru/20190923/ 1559005730.html?in=t.

89. Рождественская, Я. Человечество поставило под угрозу миллион других видов. Коммерсантъ, 06.may.2019.

90. РФ ратифицирует Парижское соглашение по климату в I квартале 2019 года. Информационное агентство Интерфакс // https:// www.interfax.ru/russia/587799. 
91. Сайт Общероссийской общественной организации «Зеленый патруль: www.geenpatrol.ru.

92. Сайт ОOH // https://www.un.org/sustainabledevelopment/ru/about/ development-agenda/.

93. Сайт Росстата // http://www.gks.ru/wps/wcm/connect/ rosstat_main/rosstat/ru/statistics/goalOfDevelopment/.

94. Сайты ТОГС // http://www.gks.ru/wps/wcm/connect/rosstat_main/ rosstat/ru/about/territorial/site/.

95. Самарина В.П. «Зеленая» экономика России: некоторые вопросы теории и методологии // Национальные интересы: приоритеты и безопасность. -2015 . - № 2 (287). - С. 2-9.

96. Седаш Т. Зарубежный опыт финансирования инфраструктурных и энергосберегающих проектов. // Управленческие науки в современном мире. 2017. Т. 1. С. 463-465.

97. Седаш Т. Переход к «зеленой» экономике в России: миф или реальность? // Финансовая жизнь. - 2016. - № 1. - С. 6-11.

98. Седаш Т. Экономические инструменты стимулирования природоохранной деятельности: анализ зарубежного опыта. // Финансы и кредит. - 2015. - № 7. - С. 54-63.

99. Соколов А.Д., Такайшвили Л.Н. Оценка ресурсов угля восточных регионов России для строительства угольных электростанций // Вестник Иркутского государственного технического университета. 2018. Т. 22. № 7. C. 155-163. DOI: 10.21285/1814-3520-2018-7-155-163.

100. Статистика Всемирного банка (World Development Indicators) / / https://mydata.biz/ru/catalog/databases/wdi; https://mydata.biz/ru/catalog/ databases/municipal_statistics.

101. Степанова М.А., Гаврильева Т.Н. Российская климатическая политика после Парижского соглашения: перспективы северных регионов // Экономика Востока России. - 2018. - № 1 (09). - С. 97-106.

102. Стратегия экологической безопасности Российской Федерации на период до 2025 года. Указ Президента России № 176 от 19.04.2017 // kremlin.ru/acts/bank/41879/page/1.

103. TACC // https://tass.ru/info/2297422.

104. TACC //http://tass.ru/ekonomika/4823713.

105. Территориальный орган Федеральной службы государственной статистики по Волгоградской области. Режим доступа: https://volgastat.gks.ru.

106. Тютюкина Е., Седаш Т. Экологические облигации и депозиты как источник финансирования природоохранных мероприятий. // Финансовая жизнь. -2015 . - № 3. - С. 58-62. 
107. Указ Президента Российской Федерации от 05.01.2016 г. № 7 «О проведении в Российской Федерации года экологии» // http://kremlin.ru/ events/president/news/51142.

108. Указ Президента Российской Федерации от 07.05.2018 г. № 204 «О национальных целях и стратегических задачах развития Российской Федерации на период до 2024 года» // http://kremlin.ru/acts/bank/43027.

109. Указ Президента РФ от 01.04.1996 № 440 «О Конщепции перехода Российской Федерации к устойчивому развитию» // http://www.consultant.ru /cons/cgi/online.cgi?req=doc;base $=\mathrm{EXP} ; \mathrm{n}=233558 \# 0893137186763888$.

110. Устойчивое развитие : Новые вызовы : Учебник для вузов / Под общ. Ред. В.И. Данилова-Данильяна, Н.А. Пискуловой. - М.: Изд-во «Аспект Пресс», 2015. - 336 с.

111. Устойчивое развитие: концепция, принципы, цели // csrjournal.com/ustojchivoe-razvitie-koncepciya-principy-celi.

112. Утверждены основы государственной политики в области экологического развития России на период до 2030 года. Сайт Президента России // http://www.kremlin.ru/events/president/news/15177.

113. Федеральный закон от 10.01.2002 № 7-Ф3 (ред. От 29.07.2018) «Об охране окружающей среды»// http://www.consultant.ru/cons/cgi/ online.cgi?req $=$ doc $\&$ base $=$ LAW $\& n=301549 \& \mathrm{fld}=134 \& \mathrm{dst}=1000000001,0 \& \mathrm{rnd}=$ $0.5121512642566695 \# 09260422738630374$.

114. Формирование финансовой поддержки банками и финансовыми организациями инвестиционных проектов и мероприятий по энергосбережению и повышению энергоэффективности : колл. монография / под ред. И. В. Ларионовой. - М. : Изд-во Кнорус, 2017, 120 с.

115. Френч Г. Трава у дома: какое будущее ждет рынок зеленых облигаций. 26.09.2017 // Интернет-сайт Forbs: http://www.forbes.ru/kompanii/ 350575-trava-u-doma-kakoe-budushchee-zhdet-rynok-zelenyh-obligaciy.

116. Шереметьева И. Волгоградской области выделят более 9 млрд руб. на экологию. Комсомольская правда-Волгоград, 12.12.2018.

117. Шкиперова Г.И. Анализ моделирования взаимосвязи между экономическим ростом и качеством окружающей среды (на примере Республике Карелия) // Экономический анализ: теория и практика. - 2014. № 43 (394). - С. 41-49.

118. Экологический след субъектов Российской Федерации / общ. Ред. П. А. Боев. - Всемирный фонд дикой природы (WWF). - M. : WWF России, 2014. -88 c.

119. Эколого-экономический индекс регионов РФ. Методика и показатели для расчета / С. Н. Бобылев, В. С. Минаков и др. - M.: WWF 
России, РИА Новости, 2012. - 152 с. // https://wwf.ru/upload/iblock/dc8/ index.pdf.

120. Яковлева Е.Ю. Экономическая оценка межотраслевых потоков природных ресурсов и загрязнений : дис. ... канд. Экон. наук: 08.00.05. M., 2016, 169 c.

121. Яшалова Н.Н. Анализ проявления эффекта декаплинга в эколого-экономической деятельности региона // Региональная экономика: теория и практика. $-2014 .-39$ (366). - С. 54-60.

122. about.amundi.com.

123. Anikina I., Anikin A., Gukova A. Decoupling" effect as a factor of regional sustainable development (evidence from Volgograd Region) // Proceedings of the International Scientific Conference "Competitive, Sustainable and Secure Development of the Regional Economy: Response to Global Challenges" (CSSDRE 2018) // https://www.atlantis-press.com/ proceedings/cssdre-18/25896426

124. China Green Bond Market Mid-Year Report 2018 // https:// www.climatebonds.net/2018/07/china-green-bond-market-mid-year-report2018-中国绿色债券市场半年报-2018).

125. Climate-awareness-bond. https://www.climatebonds.net/greenbond-segments-stock-exchanges.

126. Frankfurter Allgemeine // https://www.dw.com/ru/frankfurterallgemeine-москва-не-хочет-присоединяться-к-договору-киото-2/a16408103

127. Green bonds the state of the market, $2018 / / \mathrm{https} / /$ www.climatebonds.net/.

128. http://ecoyear.ru/about/.

129. http://eenergy.media/2017/10/03/zelenye-obligatsii-rastet-rynokekologicheskih-finansovyh-instrumentov/.

130. http://livingasia.online/2017/12/20/klimaticheskoe_finansirovanie/

131. http://www.ecoindustry.ru/news/company/view/45480.html.

132. https://theworldonly.org/indeks-chelovecheskogo-razvitiya-postranam/\#табл.

133. https://vivareit.ru/strany-lidery-po-zapasam-uglya/.

134. https://www.climatebonds.net/.

135. https://www.climatebonds.net/.

136. https://www.climatebonds.net/certification/types-of-bonds.

137. https://www.unglobalcompact.org/what-is-gc/participants.

138. https://yearbook.enerdata.ru/co2-fuel-combustion/CO2-emissionsdata-from-fuel-combustion.html. 
139. https://yearbook.enerdata.ru/co2-fuel-combustion/world-CO2intensity.html.

140. John F. Helliwell, Richard Layard and Jeffrey D. Sachs.World Happiness Report 2019, New York: Sustainable Development Solutions Network.

141. Living Planet Report 2018 Technical Supplement: Living Planet Index; Экологический след субъектов Российской Федерации / общ. ред. П. А. Боев. - Всемирный фонд дикой природы (WWF). - M.: WWF России, 2014.$88 \mathrm{c}$.

142. Report of the Technical Expert Group (TEG) subgroup on Green Bond Standard. Proposal for an EU Green Bond Standard. Interim Report. Document for feedback. Green Bond Standard Subgroup 6 March 2019.

143. System of Environment-Ecomonic Accounting 2012 : Applications and Extensions (White cover publication/ pre-edited text subject to official editing). Eurorean Commission, FAO, OECD, United Natoins, World Bank, 2014b.

144. The Changing Wealth of Nations. Measuring Sustainable Development in the New Millennium. 2011, The International Bank for Reconstruction and Development / The World Bank // ISBN 978-0-82138488-6 - ISBN 978-0-8213-8554-8 (electronic).

145. The World Only.От понимания к устойчивому развитию. News of the age of sustainable development // https://theworldonly.org/indekschelovecheskogo-razvitiya-po-stranam/.

146. The World Only.От понимания к устойчивому развитию. News of the age of sustainable development // https://theworldonly.org/indeksschastya-2019/; Statistical Appendix 1 for Chapter 2 of World Happiness Report 2019, by John F. Helliwell, Haifang Huang and Shun Wang, . March 7, 2019; https://worldhappiness.report/.

147. unepinquiry.org/countries/.

148. www.ipe.com.

149. www.ipe.com. 


\section{ПРИЛОЖЕНИЯ}

Приложение A

Таблица A1

\section{Характеристика эффекта декаплинга (на примере регионов ЦФО)}

\begin{tabular}{|c|c|c|c|c|c|c|c|}
\hline Показатели & 2010 & 2011 & 2012 & 2013 & 2014 & 2015 & 2016 \\
\hline \multicolumn{8}{|c|}{ Белгородская область, Reea $=1,62, \mathrm{Reea}^{\prime}=1,33$} \\
\hline R, тыс. тонн & 132,410 & 134,500 & 133,970 & 117,720 & 127,410 & 118,390 & 112,850 \\
\hline$\Delta \mathrm{R}$, отн. ед. & - & 0,016 & $-0,007$ & $-0,124$ & 0,080 & $-0,073$ & $-0,048$ \\
\hline ТY, отн. ед & 1,096 & 1,109 & 1,052 & 1,027 & 1,026 & 1,028 & 1,032 \\
\hline$\Delta$ TY, отн. ед. & - & 0,109 & 0,052 & 0,027 & 0,026 & 0,028 & 0,032 \\
\hline Сектор по $R$ & - & 2 & 1 & 1 & 4 & 1 & 1 \\
\hline$\Delta \mathrm{R}^{\prime}$, отн. ед. & & 0,016 & 0,009 & $-0,116$ & $-0,045$ & $-0,115$ & $-0,158$ \\
\hline TY', отн. ед. & & 1,109 & 1,167 & 1,198 & 1,229 & 1,264 & 1,304 \\
\hline$\Delta \mathrm{TY}^{\prime}$, отн. ед. & & 0,109 & 0,167 & 0,198 & 0,229 & 0,264 & 0,304 \\
\hline Сектор по $R^{\prime}$ & & 2 & 2 & 1 & 1 & 1 & 1 \\
\hline \multicolumn{8}{|c|}{ Брянская область, Reea $=2,71$, Reea $^{\prime}=2,00$} \\
\hline R, тыс. тонн & 34,950 & 36,890 & 39,040 & 36,730 & 36,180 & 37,360 & 38,740 \\
\hline$\Delta \mathrm{R}$, отн. ед. & - & 0,065 & 0,067 & $-0,052$ & $-0,005$ & 0,040 & 0,043 \\
\hline ТY, отн. ед & 1,052 & 1,092 & 1,093 & 1,019 & 1,043 & 1,022 & 1,008 \\
\hline$\Delta$ TY, отн. ед. & - & 0,092 & 0,093 & 0,019 & 0,043 & 0,022 & 0,008 \\
\hline Сектор (по R) & - & 2 & 2 & 1 & 1 & 4 & 4 \\
\hline$\Delta \mathrm{R}^{\prime}$, отн. ед. & & 0,065 & 0,137 & 0,079 & 0,073 & 0,116 & 0,164 \\
\hline TY', отн. ед. & & 1,092 & 1,194 & 1,216 & 1,269 & 1,296 & 1,307 \\
\hline$\Delta \mathrm{TY}^{\prime}$, отн. ед. & & 0,092 & 0,194 & 0,216 & 0,269 & 0,296 & 0,307 \\
\hline Сектор по $R^{\prime}$ & & 2 & 2 & 2 & 2 & 2 & 2 \\
\hline \multicolumn{8}{|c|}{ Владимирская область, Reea $=2,52$, Reea $^{\prime}=1,167$} \\
\hline R, тыс. тонн & 35,500 & 35,450 & 31,940 & 32,380 & 30,720 & 30,090 & 33,490 \\
\hline$\Delta \mathrm{R}$, отн. ед. & - & 0,005 & $-0,093$ & 0,021 & $-0,045$ & $-0,016$ & 0,120 \\
\hline ТY, отн. ед & 1,073 & 1,035 & 1,029 & 1,021 & 1,014 & 0,990 & 1,012 \\
\hline$\Delta$ TY, отн. ед. & - & 0,035 & 0,029 & 0,021 & 0,014 & $-0,010$ & 0,012 \\
\hline Сектор (по R) & - & 2 & 1 & 2 & 1 & 3 & 4 \\
\hline$\Delta \mathrm{R}^{\prime}$, отн. ед. & & 0,005 & $-0,089$ & $-0,070$ & $-0,112$ & $-0,126$ & $-0,021$ \\
\hline TY', отн. ед. & & 1,005 & 0,911 & 0,930 & 0,888 & 0,874 & 0,979 \\
\hline$\Delta \mathrm{TY}^{\prime}$, отн. ед. & & 0,035 & 0,065 & 0,087 & 0,103 & 0,092 & 0,105 \\
\hline Сектор по $R$ & & 2 & 1 & 1 & 1 & 1 & 1 \\
\hline
\end{tabular}


Продолжение таблицы A1

\begin{tabular}{|c|c|c|c|c|c|c|c|}
\hline Показатели & 2010 & 2011 & 2012 & 2013 & 2014 & 2015 & 2016 \\
\hline \multicolumn{8}{|c|}{ Воронежская область, Reea $=2,67$, Reea $^{\prime}=1,167$} \\
\hline R, тыс. тонн & 77,310 & 72,220 & 78,770 & 75,780 & 67,880 & 69,200 & 72,690 \\
\hline$\Delta \mathrm{R}$, отн. ед. & - & $-0,066$ & 0,092 & $-0,037$ & $-0,104$ & 0,019 & 0,050 \\
\hline ТY, отн. ед & 1,013 & 1,115 & 1,094 & 1,023 & 1,059 & 1,004 & 1,013 \\
\hline$\Delta$ ТY, отн. ед. & - & 0,115 & 0,094 & 0,023 & 0,059 & 0,004 & 0,013 \\
\hline Сектор (по R) & - & 1 & 2 & 1 & 1 & 4 & 4 \\
\hline$\Delta R^{\prime}$, отн. ед. & & $-0,066$ & 0,020 & $-0,018$ & $-0,120$ & $-0,103$ & $-0,059$ \\
\hline TY', отн. ед. & & 1,115 & 1,220 & 1,248 & 1,321 & 1,327 & 1,344 \\
\hline$\Delta$ TY $^{\prime}$, отн. ед. & & 0,115 & 0,220 & 0,248 & 0,321 & 0,327 & 0,344 \\
\hline Сектор по $R^{\prime}$ & & 1 & 2 & 1 & 1 & 1 & 1 \\
\hline \multicolumn{8}{|c|}{ Ивановская область, Reea $=3,14$, Reea $=2,500$} \\
\hline $\mathrm{R}$, тыс & 36,680 & 36,650 & 29,450 & 30,350 & 33,170 & 33,480 & 26,970 \\
\hline$\Delta \mathrm{R}$, отн. ед. & - & 0,007 & $-0,192$ & 0,035 & 0,099 & 0,015 & $-0,189$ \\
\hline ТY, отн. ед & 1,025 & 1,012 & 0,969 & 1,056 & 0,904 & 1,019 & 0,971 \\
\hline$\Delta$ ТҮ, отн. ед. & - & 0,012 & $-0,031$ & 0,056 & $-0,096$ & 0,019 & $-0,029$ \\
\hline Сектор (по R) & - & 2 & 3 & 2 & 6 & 2 & 3 \\
\hline$\Delta \mathrm{R}^{\prime}$, отн. ед. & & 0,007 & $-0,186$ & $-0,158$ & $-0,074$ & $-0,060$ & $-0,238$ \\
\hline $\mathrm{TY}^{\prime}, \mathrm{o}$ & & 12 & 81 & 1,036 & 0,936 & 0,954 & 0,926 \\
\hline$\Delta \mathrm{TY}^{\prime}$, отн. ед. & & 0,012 & $-0,019$ & 0,036 & $-0,064$ & $-0,046$ & $-0,074$ \\
\hline Секто & & 2 & 3 & 1 & 3 & 3 & 3 \\
\hline \multicolumn{8}{|c|}{ Калужская область, Reea $=3,62$, Reea $^{\prime}=3,333$} \\
\hline $\mathrm{R}, \mathrm{T}$ & 12,070 & 12,600 & 12,980 & 15,290 & 19,480 & 25,600 & 23,460 \\
\hline$\Delta \mathrm{R}$, отн. ед. & - & 0,050 & 0,031 & 0,180 & 0,275 & 0,306 & $-0,083$ \\
\hline TY, & 1,104 & 1,132 & 98 & 0,974 & 1,029 & 0,943 & 1,025 \\
\hline$\Delta$ ТY, отн. ед. & - & 0,132 & 0,098 & $-0,026$ & 0,029 & $-0,057$ & 0,025 \\
\hline (по R) & - & 1 & 2 & 6 & 6 & 1 & 1 \\
\hline$\Delta \mathrm{R}^{\prime}$ & & 0,050 & 0,083 & 0,278 & 0,630 & 29 & 0,953 \\
\hline $\mathrm{TY}^{\prime}, \mathrm{o}$ & & & 43 & 1,211 & 1,246 & 1,175 & 1,204 \\
\hline$\Delta \mathrm{TY}^{\prime}, \mathrm{c}$ & & 0,132 & 0,243 & 0,211 & 0,246 & 0,175 & 0,204 \\
\hline Сект & & 2 & 2 & 4 & 4 & 4 & 4 \\
\hline \multicolumn{8}{|c|}{ Костромская область, Reea $=3,00$, Reea $=1,000$} \\
\hline $\mathrm{R}$, ты & 53,570 & 50,370 & 52,300 & 50,190 & 48,810 & 46,240 & 50,490 \\
\hline$\Delta \mathrm{R}$, & - & $-0,050$ & 0,045 & $-0,036$ & $-0,023$ & $-0,050$ & 0,097 \\
\hline ТY, отн. ед & 1,072 & 1,047 & 1,047 & 1,027 & 1,007 & 0,990 & 0,973 \\
\hline$\Delta$ ТY, отн. ед. & - & 0,047 & 0,047 & 0,027 & 0,007 & $-0,010$ & $-0,027$ \\
\hline Сектор (по R) & - & 1 & 2 & 1 & 1 & 3 & 6 \\
\hline$\Delta \mathrm{R}^{\prime}$, отн. ед. & & $-0,050$ & $-0,007$ & $-0,043$ & $-0,065$ & $-0,112$ & $-0,026$ \\
\hline ТY, отн. ед. & & 1,047 & 1,096 & 1,126 & 1,134 & 1,122 & 1,092 \\
\hline$\Delta$ TY$^{\prime}$, отн. ед. & & 0,047 & 0,096 & 0,126 & 0,134 & 0,122 & 0,092 \\
\hline Сектор по $R^{\prime}$ & & 1 & 1 & 1 & 1 & 1 & 1 \\
\hline \multicolumn{8}{|c|}{ Курская область, Reea $=1,91$, Reea $=1,333$} \\
\hline $\mathrm{R}, \mathrm{T}$ & 41,390 & 41,950 & 41,490 & 37,940 & 35,960 & 31,310 & 38,800 \\
\hline$\Delta \mathrm{R}$, отн. ед. & - & 0,022 & $-0,007$ & $-0,083$ & $-0,052$ & $-0,128$ & 0,236 \\
\hline
\end{tabular}


Продолжение таблицы АI

\begin{tabular}{|c|c|c|c|c|c|c|c|}
\hline Показатели & 2010 & 2011 & 2012 & 2013 & 2014 & 2015 & 2016 \\
\hline ТY, отн. ед & 1,038 & 1,091 & 1,050 & 1,043 & 1,046 & 1,029 & 1,037 \\
\hline$\Delta$ ТҮ, отн. ед. & - & 0,091 & 0,050 & 0,043 & 0,046 & 0,029 & 0,037 \\
\hline Сектор (по R) & - & 2 & 1 & 1 & 1 & 1 & 4 \\
\hline$\Delta \mathrm{R}^{\prime}$, отн. ед. & & 0,022 & 0,014 & $-0,070$ & $-0,119$ & $-0,231$ & $-0,050$ \\
\hline $\mathrm{TY}^{\prime}, \mathrm{O}$ & & 1,091 & 1,146 & 1,195 & 1,250 & 1,286 & 1,334 \\
\hline$\Delta \mathrm{TY}^{\prime}$, отн. ед. & & 0,091 & 0,146 & 0,195 & 0,250 & 0,286 & 0,334 \\
\hline Сектор по $R$ & & 2 & 2 & 1 & 1 & 1 & 1 \\
\hline \multicolumn{8}{|c|}{ Липецкая область, Reea $=1,14$, Reea $^{\prime}=1,00$} \\
\hline R, тыс. & 367,630 & 344,910 & 338,750 & 346,680 & 330,000 & 327,690 & 320,360 \\
\hline$\Delta \mathrm{R}, \mathrm{OTl}$ & - & $-0,058$ & $-0,013$ & 0,027 & $-0,046$ & $-0,005$ & $-0,021$ \\
\hline TY, OT & 1,044 & 1,053 & 022 & 1,037 & 1,053 & 1,012 & 1,017 \\
\hline$\Delta \mathrm{TY}$, & - & 0,053 & 0,022 & 0,037 & 0,053 & 0,012 & 0,017 \\
\hline Сектор & - & 1 & 1 & 2 & 1 & 1 & 1 \\
\hline$\Delta \mathrm{R}^{\prime}, \mathrm{o}$ & & $-0,058$ & $-0,070$ & $-0,045$ & $-0,089$ & $-0,094$ & $-0,113$ \\
\hline $\mathrm{TY}^{\prime}, \mathrm{o}$ & & 1,053 & 1,076 & 1,116 & 1,175 & 1,189 & 1,209 \\
\hline$\Delta \mathrm{TY}^{\prime}, \mathrm{c}$ & & 0,053 & 0,076 & 0,116 & 0,175 & 0,189 & 0,209 \\
\hline Секто & & 1 & 1 & 1 & 1 & 1 & 1 \\
\hline \multicolumn{8}{|c|}{ Московская область, Reea $=2,67$, Reea $^{\prime}=1,50$} \\
\hline R, тыс & 204,650 & 192,390 & 188,950 & 198,990 & 196,640 & 196,640 & 253,330 \\
\hline$\Delta \mathrm{R}, \mathrm{O}$ & - & $-0,071$ & $-0,031$ & 0,076 & $-0,024$ & $-0,013$ & 0,273 \\
\hline TY, o & 1,065 & 1,068 & 1,070 & 1,009 & 988 & 1,013 & 1,020 \\
\hline$\Delta \mathrm{TY}$, & - & 0,068 & 0,070 & 0,009 & $-0,012$ & 0,013 & 0,020 \\
\hline Сектор & - & 1 & 1 & 4 & 3 & 1 & 4 \\
\hline$\Delta \mathrm{R}^{\prime}, \mathrm{O}$ & & $-0,071$ & $-0,099$ & $-0,031$ & $-0,054$ & $-0,067$ & 0,188 \\
\hline $\mathrm{TY}^{\prime}, \mathrm{o}$ & & 1,068 & 1,143 & 1,153 & 1,139 & 1,154 & 1,177 \\
\hline$\Delta \mathrm{TY}^{\prime}$, & & 0,068 & 0,143 & 0,153 & 0,139 & 0,154 & 0,177 \\
\hline Секто & & 1 & 1 & 1 & 1 & 1 & 4 \\
\hline \multicolumn{8}{|c|}{ Орловская область, Reea $=2,91$, Reea $^{\prime}=1,333$} \\
\hline $\mathrm{R}$, ты & 22,760 & 23,270 & 11,080 & 23,770 & 15,330 & 13,450 & 20,690 \\
\hline$\Delta \mathrm{R}, \mathrm{O}$ & - & 0,032 & $-0,521$ & & $-0,350$ & $-0,117$ & 0,548 \\
\hline TY, o & 1,042 & 1,142 & 1,045 & 1,025 & 1,021 & 1,031 & 0,986 \\
\hline$\Delta \mathrm{TY}$, & - & 0,142 & 0,045 & 0,025 & 0,021 & 0,031 & $-0,014$ \\
\hline Сектор & - & 2 & 1 & 4 & 1 & 1 & 6 \\
\hline$\Delta \mathrm{R}^{\prime}$, отн. ед. & & 0,032 & $-0,506$ & 0,067 & $-0,306$ & $-0,387$ & $-0,051$ \\
\hline $\mathrm{TY}^{\prime}, \mathrm{o}$ & & 1,142 & 1,193 & 1,223 & 1,249 & 1,288 & 1,270 \\
\hline$\Delta \mathrm{TY}^{\prime}$ & & 0,142 & 0,193 & 0,223 & 0,249 & 0,288 & 0,270 \\
\hline Секто & & 2 & 1 & 2 & 1 & 1 & 1 \\
\hline \multicolumn{8}{|c|}{ Рязанская область, Reea $=3,95$, Reea $=1,00$} \\
\hline R, тыс & 133,870 & 121,530 & 123,540 & 103,190 & 107,980 & 98,490 & 99,450 \\
\hline$\Delta \mathrm{R}, \mathrm{O}$ & - & $-0,084$ & 0,020 & $-0,162$ & 0,049 & $-0,083$ & 0,014 \\
\hline TY, o & 1,052 & 1,093 & 1,053 & 1,028 & 0,994 & 0,986 & 0,995 \\
\hline$\Delta \mathrm{TY}, \mathrm{o}$ & - & 0,093 & 0,053 & 0,028 & $-0,006$ & $-0,014$ & $-0,005$ \\
\hline Сектор (по R) & - & 1 & 2 & 1 & 6 & 3 & 6 \\
\hline$\Delta R^{\prime}$, отн. ед. & & $-0,084$ & $-0,066$ & $-0,217$ & $-0,179$ & $-0,247$ & $-0,236$ \\
\hline $\mathrm{TY}^{\prime}, \mathrm{O}$ & & 1,093 & 1,151 & 1,183 & 1,176 & 1,160 & 1,154 \\
\hline$\Delta \mathrm{TY}^{\prime}$, отн. ед. & & 0,093 & 0,151 & 0,183 & 0,176 & 0,160 & 0,154 \\
\hline Сектор по $R$ & & 1 & 1 & 1 & 1 & 1 & 1 \\
\hline
\end{tabular}


Продолжение таблиць АI

\begin{tabular}{|c|c|c|c|c|c|c|c|}
\hline Показатели & 2010 & 2011 & 2012 & 2013 & 2014 & 2015 & 2016 \\
\hline \multicolumn{8}{|c|}{ Смоленская область, Reea $=3,81$, Reea $=2,83$} \\
\hline R, тыс. тонн & 48,330 & 48,440 & 46,040 & 58,680 & 52,720 & 59,400 & 58,290 \\
\hline$\Delta \mathrm{R}$, отн. ед. & - & 0,012 & $-0,048$ & 0,282 & $-0,095$ & 0,130 & $-0,013$ \\
\hline ТY, отн. ед & 1,084 & 1,053 & 1,046 & 1,051 & 1,009 & 0,996 & 0,983 \\
\hline$\Delta$ ТY, отн. ед. & - & 0,053 & 0,046 & 0,051 & 0,009 & $-0,004$ & $-0,017$ \\
\hline Сектор (по R) & - & 2 & 1 & 4 & 1 & 6 & 5 \\
\hline$\Delta \mathrm{R}^{\prime}$, отн. ед. & & 0,012 & $-0,036$ & 0,237 & 0,119 & 0,265 & 0,249 \\
\hline ТY, отн. ед. & & 1,053 & 1,101 & 1,158 & 1,168 & 1,163 & 1,144 \\
\hline$\Delta \mathrm{TY}^{\prime}$, отн. ед. & & 0,053 & 0,101 & 0,158 & 0,168 & 0,163 & 0,144 \\
\hline Сектор по $R^{\prime}$ & & 2 & 1 & 4 & 2 & 4 & 4 \\
\hline \multicolumn{8}{|c|}{ Тамбовская область, Reea $=3,43$, Reea $^{\prime}=1,83$} \\
\hline R, тыс. тонн & 46,190 & 47,720 & 51,510 & 53,880 & 44,690 & 56,440 & 56,040 \\
\hline$\Delta \mathrm{R}$, отн. ед. & - & 0,043 & 0,087 & 0,052 & $-0,165$ & 0,271 & 0,004 \\
\hline TY, отн. ед & 0,978 & 1,137 & 1,096 & 1,099 & 1,063 & 1,079 & 0,961 \\
\hline \begin{tabular}{|l}
$\Delta$ ТY, отн. ед. \\
\end{tabular} & - & 0,137 & 0,096 & 0,099 & 0,063 & 0,079 & $-0,039$ \\
\hline Сектор (по R) & - & 2 & 2 & 2 & 1 & 4 & 6 \\
\hline$\Delta \mathrm{R}^{\prime}$, отн. ед. & & 0,043 & 0,134 & 0,193 & $-0,004$ & 0,266 & 0,271 \\
\hline TY', отн. ед. & & 1,137 & 1,246 & 1,370 & 1,456 & 1,571 & 1,510 \\
\hline$\Delta \mathrm{TY}^{\prime}$, отн. ед. & & 0,137 & 0,246 & 0,370 & 0,456 & 0,571 & 0,510 \\
\hline Сектор по $R^{\prime}$ & & 2 & 2 & 2 & 1 & 2 & 2 \\
\hline
\end{tabular}

Тверская область, Reea $=2,95$, Reea $^{\prime}=2,67$

\begin{tabular}{|l|c|r|r|r|r|r|r|}
\hline $\mathrm{R}$, тыс. тонн & 60,070 & 66,690 & 63,070 & 60,240 & 69,080 & 59,510 & 62,960 \\
\hline$\Delta \mathrm{R}$, отн. ед. & - & 0,123 & $-0,049$ & $-0,039$ & 0,155 & $-0,132$ & 0,066 \\
\hline $\mathrm{TY}$, отн. ед & 1,043 & 1,067 & 1,006 & 1,016 & 0,996 & 1,002 & 1,022 \\
\hline$\Delta$ ТY, отн. ед. & - & 0,067 & 0,006 & 0,016 & $-0,004$ & 0,002 & 0,022 \\
\hline Сектор (по R) & - & 4 & 1 & 1 & 6 & 1 & 4 \\
\hline$\Delta \mathrm{R}^{\prime}$, отн. ед. & & 0,123 & 0,068 & 0,026 & 0,185 & 0,028 & 0,096 \\
\hline $\mathrm{TY}^{\prime}$, отн. ед. & & 1,067 & 1,073 & 1,091 & 1,086 & 1,088 & 1,112 \\
\hline$\Delta$ TY$^{\prime}$, отн. ед. & & 0,067 & 0,073 & 0,091 & 0,086 & 0,088 & 0,112 \\
\hline Сектор по $R^{\prime}$ & & 4 & 2 & 2 & 4 & 2 & 2 \\
\hline
\end{tabular}

Тульская область, Reea $=1,43$, Reea $^{\prime}=2,33$

\begin{tabular}{|l|c|r|r|r|r|r|r|}
\hline $\mathrm{R}$, тыс. тонн & 167,110 & 192,710 & 197,750 & 180,640 & 181,320 & 148,960 & 141,760 \\
\hline$\Delta \mathrm{R}$, отн. ед. & - & 0,164 & 0,029 & $-0,079$ & 0,010 & $-0,174$ & $-0,043$ \\
\hline $\mathrm{TY}$ отн. ед & 1,044 & 1,059 & 1,031 & 1,051 & 1,064 & 1,061 & 1,046 \\
\hline$\Delta$ ТҮ, отн. ед. & - & 0,059 & 0,031 & 0,051 & 0,064 & 0,061 & 0,046 \\
\hline Сектор (по R) & - & 4 & 2 & 1 & 2 & 1 & 1 \\
\hline$\Delta \mathrm{R}^{\prime}$, отн. ед. & & 0,164 & 0,198 & 0,104 & 0,115 & $-0,079$ & $-0,119$ \\
\hline $\mathrm{TY}^{\prime}$, отн. ед. & & 1,059 & 1,092 & 1,148 & 1,221 & 1,295 & 1,355 \\
\hline$\Delta \mathrm{TY}^{\prime}$, отн. ед. & & 0,059 & 0,092 & 0,148 & 0,221 & 0,295 & 0,355 \\
\hline Сектор по $R^{\prime}$ & & 4 & 4 & 2 & 2 & 1 & 1 \\
\hline
\end{tabular}

Ярославская область, Reea $=2,71, \mathrm{Reea}^{\prime}=1,67$

\begin{tabular}{|l|c|r|r|r|r|r|r|}
\hline $\mathrm{R}$, тыс. тонн & 80,800 & 78,290 & 77,310 & 81,540 & 88,330 & 90,840 & 86,110 \\
\hline$\Delta \mathrm{R}$, отн. ед. & - & $-0,024$ & $-0,013$ & 0,054 & 0,083 & 0,028 & $-0,052$ \\
\hline
\end{tabular}


Окончание таблицы AI

\begin{tabular}{|c|c|c|c|c|c|c|c|}
\hline Показатели & 2010 & 2011 & 2012 & 2013 & 2014 & 2015 & 2016 \\
\hline ТY, отн. ед & 1,036 & 1,074 & 1,046 & 1,026 & 1,019 & 1,004 & 1,012 \\
\hline$\Delta$ ТY, отн. ед. & - & 0,074 & 0,046 & 0,026 & 0,019 & 0,004 & 0,012 \\
\hline Сектор (по R) & - & 1 & 1 & 4 & 4 & 4 & 1 \\
\hline$\Delta \mathrm{R}^{\prime}$, отн. ед. & & $-0,024$ & $-0,036$ & 0,016 & 0,100 & 0,131 & 0,072 \\
\hline ТY, отн. ед. & & 1,074 & 1,123 & 1,153 & 1,175 & 1,179 & 1,193 \\
\hline$\Delta \mathrm{TY}^{\prime}$, отн. ед. & & 0,074 & 0,123 & 0,153 & 0,175 & 0,179 & 0,193 \\
\hline Сектор по $R^{\prime}$ & & 1 & 1 & 2 & 2 & 2 & 2 \\
\hline \multicolumn{8}{|c|}{ г. Москва, Reea $=3,00$, Reea $=2,33$} \\
\hline R, тыс. тонн & 62,920 & 61,250 & 71,640 & 65,960 & 67,650 & 63,160 & 63,010 \\
\hline$\Delta \mathrm{R}, \mathrm{OT}$ & - & $-0,040$ & 0,162 & $-0,107$ & 0,015 & $-0,073$ & $-0,013$ \\
\hline ТY, отн. ед & 1,003 & 1,018 & 1,001 & 0,999 & 0,993 & 0,970 & 1,003 \\
\hline$\Delta$ TY, отн. ед. & - & 0,018 & 0,001 & $-0,001$ & $-0,007$ & $-0,030$ & 0,003 \\
\hline Сектор (по R) & - & 1 & 4 & 3 & 6 & 3 & 1 \\
\hline$\Delta \mathrm{R}^{\prime}$, отн. ед. & & $-0,040$ & 0,116 & $-0,004$ & 0,011 & $-0,063$ & $-0,076$ \\
\hline ТY', отн. ед. & & 1,018 & 1,019 & 1,018 & 1,011 & 0,981 & 0,983 \\
\hline$\Delta \mathrm{TY}^{\prime}$, отн. ед. & & 0,018 & 0,019 & 0,018 & 0,011 & $-0,019$ & $-0,017$ \\
\hline Сектор по $R^{\prime}$ & & 1 & 4 & 1 & 2 & 3 & 3 \\
\hline
\end{tabular}

Таблиияа А2

Характеристика эффекта декаплинга (на примере регионов СЗФО)

\begin{tabular}{|c|c|c|c|c|c|c|c|}
\hline Показатели & 2010 & 2011 & 2012 & 2013 & 2014 & 2015 & 2016 \\
\hline \multicolumn{8}{|c|}{ Республика Карелия, Reea $=3,29$, Reea $^{\prime}=2,17$} \\
\hline R, тыс. тонн & 107,920 & 96,020 & 106,600 & 118,500 & 94,930 & 95,910 & 116,030 \\
\hline$\Delta \mathrm{R}$, отн. ед. & - & $-0,102$ & 0,115 & 0,117 & $-0,195$ & 0,012 & 0,216 \\
\hline ТY, отн. ед & 1,053 & 1,029 & 1,019 & 1,011 & 1,004 & 1,008 & 1,005 \\
\hline$\Delta$ ТY, отн. ед. & - & 0,029 & 0,019 & 0,011 & 0,004 & 0,008 & 0,005 \\
\hline Сектор (по R) & - & 1 & 4 & 4 & 1 & 4 & 4 \\
\hline$\Delta \mathrm{R}^{\prime}$, отн. ед. & & $-0,102$ & 0,002 & 0,119 & $-0,100$ & $-0,089$ & 0,108 \\
\hline TY', отн. ед. & & 0,898 & 1,002 & 1,119 & 0,900 & 0,911 & 1,108 \\
\hline$\Delta \mathrm{TY}^{\prime}$, отн. ед. & & 0,029 & 0,049 & 0,060 & 0,064 & 0,073 & 0,078 \\
\hline Сектор по $R^{\prime}$ & & 1 & 2 & 4 & 1 & 1 & 4 \\
\hline \multicolumn{8}{|c|}{ Республика Коми, Reea $=3,29$, Reea $^{\prime}=3,67$} \\
\hline R, тыс. тонн & 594,780 & 712,350 & 688,220 & 774,320 & 707,010 & 612,230 & 568,850 \\
\hline$\Delta \mathrm{R}$, отн. ед. & - & 0,215 & $-0,024$ & 0,138 & $-0,079$ & $-0,126$ & $-0,063$ \\
\hline ТY, отн. ед & 1,040 & 1,070 & 1,028 & 0,977 & 0,966 & 0,992 & 0,993 \\
\hline$\Delta$ TY, отн. ед. & - & 0,070 & 0,028 & $-0,023$ & $-0,034$ & $-0,008$ & $-0,007$ \\
\hline Сектор (по R) & - & 4 & 1 & 6 & 3 & 3 & 3 \\
\hline$\Delta R^{\prime}$, отн. ед. & & 0,215 & 0,186 & 0,349 & 0,243 & 0,087 & 0,018 \\
\hline TY', отн. ед. & & 1,070 & 1,100 & 1,075 & 1,038 & 1,030 & 1,023 \\
\hline$\Delta \mathrm{TY}^{\prime}$, отн. ед. & & 0,070 & 0,100 & 0,075 & 0,038 & 0,030 & 0,023 \\
\hline Сектор по $R$ & & 4 & 4 & 4 & 4 & 4 & 2 \\
\hline
\end{tabular}


Продолжение таблицы $A 2$

\begin{tabular}{|c|c|c|c|c|c|c|c|}
\hline Показатели & 2010 & 2011 & 2012 & 2013 & 2014 & 2015 & 2016 \\
\hline \multicolumn{8}{|c|}{ Архангельская область, Reea $=1,57$, Reea $^{\prime}=1,00$} \\
\hline R, тыс. тонн & 545,250 & 372,990 & 270,610 & 245,400 & 261,950 & 259,580 & 245,040 \\
\hline$\Delta R$, отн. ед. & - & $-0,309$ & $-0,267$ & $-0,085$ & 0,076 & $-0,002$ & $-0,049$ \\
\hline ТY, отн. ед & 1,017 & 1,027 & 1,015 & 1,020 & 1,028 & 1,040 & 1,033 \\
\hline$\Delta$ TY, отн. ед. & - & 0,027 & 0,015 & 0,020 & 0,028 & 0,040 & 0,033 \\
\hline Сектор (по R) & - & 1 & 1 & 1 & 4 & 1 & 1 \\
\hline$\Delta \mathrm{R}^{\prime}$, отн. ед. & & $-0,309$ & $-0,494$ & $-0,537$ & $-0,501$ & $-0,502$ & $-0,526$ \\
\hline TY', отн. ед. & & 1,027 & 1,042 & 1,063 & 1,093 & 1,137 & 1,174 \\
\hline$\Delta \mathrm{TY}^{\prime}$, отн. ед. & & 0,027 & 0,042 & 0,063 & 0,093 & 0,137 & 0,174 \\
\hline Сектор по $R^{\prime}$ & & 1 & 1 & 1 & 1 & 1 & 1 \\
\hline \multicolumn{8}{|c|}{ Вологодская область, Reea $=1,81$, Reea $^{\prime}=1,50$} \\
\hline R, тыс. тонн & 473,890 & 469,060 & 473,380 & 499,160 & 490,960 & 461,230 & 440,540 \\
\hline$\Delta \mathrm{R}$, отн. ед. & - & $-0,004$ & 0,012 & 0,056 & $-0,014$ & $-0,059$ & $-0,042$ \\
\hline ТY, отн. ед & 1,062 & 1,073 & 1,050 & 0,959 & 1,032 & 1,015 & 1,004 \\
\hline$\triangle \mathrm{TY}$, отн. ед. & - & 0,073 & 0,050 & $-0,041$ & 0,032 & 0,015 & 0,004 \\
\hline Сектор (по R) & - & 1 & 2 & 6 & 1 & 1 & 1 \\
\hline$\Delta \mathrm{R}^{\prime}$, отн. ед. & & $-0,004$ & 0,007 & 0,064 & 0,049 & $-0,013$ & $-0,055$ \\
\hline ТY, отн. ед. & & 1,073 & 1,127 & 1,080 & 1,115 & 1,132 & 1,136 \\
\hline$\triangle \mathrm{TY}^{\prime}$, отн. ед. & & 0,073 & 0,127 & 0,080 & 0,115 & 0,132 & 0,136 \\
\hline Сектор по $R^{\prime}$ & & 1 & 2 & 2 & 2 & 1 & 1 \\
\hline \multicolumn{8}{|c|}{ Калининградская область, Reea $=3,14$, Reea $^{\prime}=1,00$} \\
\hline R, тыс. тонн & 29,470 & 24,610 & 25,100 & 20,510 & 18,940 & 20,100 & 20,590 \\
\hline$\Delta \mathrm{R}$, отн. ед. & - & $-0,168$ & 0,015 & $-0,190$ & $-0,084$ & 0,055 & 0,017 \\
\hline ТY, отн. ед & 1,073 & 1,042 & 1,040 & 1,001 & 1,039 & 0,978 & 1,013 \\
\hline$\Delta$ TY, отн. ед. & - & 0,042 & 0,040 & 0,001 & 0,039 & $-0,022$ & 0,013 \\
\hline Сектор (по R) & - & 1 & 2 & 1 & 1 & 6 & 4 \\
\hline$\Delta \mathrm{R}^{\prime}$, отн. ед. & & $-0,168$ & $-0,156$ & $-0,316$ & $-0,374$ & $-0,340$ & $-0,329$ \\
\hline ТY, отн. ед. & & 1,042 & 1,084 & 1,085 & 1,127 & 1,102 & 1,117 \\
\hline$\Delta \mathrm{TY}^{\prime}$, отн. ед. & & 0,042 & 0,084 & 0,085 & 0,127 & 0,102 & 0,117 \\
\hline Сектор по $R^{\prime}$ & & 1 & 1 & 1 & 1 & 1 & 1 \\
\hline \multicolumn{8}{|c|}{ Ленинградская область, Reea $=2,76, \mathrm{Reea}^{\prime}=2,00$} \\
\hline R, тыс. тонн & 225,780 & 215,790 & 228,910 & 244,720 & 271,580 & 246,980 & 243,420 \\
\hline$\Delta \mathrm{R}$, отн. ед. & - & $-0,052$ & 0,052 & 0,059 & 0,102 & $-0,097$ & $-0,016$ \\
\hline ТY, отн. ед & 1,048 & 1,057 & 1,053 & 0,977 & 0,995 & 1,042 & 1,013 \\
\hline$\Delta \mathrm{TY}$, отн. ед. & - & 0,057 & 0,053 & $-0,023$ & $-0,005$ & 0,042 & 0,013 \\
\hline Сектор (по R) & - & 1 & 2 & 6 & 6 & 1 & 1 \\
\hline$\Delta \mathrm{R}^{\prime}$, отн. ед. & & $-0,052$ & $-0,003$ & 0,055 & 0,163 & 0,050 & 0,033 \\
\hline ТY, отн. ед. & & 1,057 & 1,113 & 1,087 & 1,082 & 1,127 & 1,142 \\
\hline$\Delta \mathrm{TY}^{\prime}$, отн. ед. & & 0,057 & 0,113 & 0,087 & 0,082 & 0,127 & 0,142 \\
\hline Сектор по $R^{\prime}$ & & 1 & 1 & 2 & 4 & 2 & 2 \\
\hline \multicolumn{8}{|c|}{ Мурманская область, Reea $=2,23$, Reea $^{\prime}=1,17$} \\
\hline $\mathrm{R}$, тыс. тонн & 287,630 & 263,130 & 258,860 & 269,770 & 276,420 & 275,840 & 231,810 \\
\hline$\Delta \mathrm{R}$, отн. ед. & - & $-0,078$ & $-0,009$ & 0,053 & 0,037 & 0,004 & $-0,155$ \\
\hline
\end{tabular}


Окончнание таблииы А2

\begin{tabular}{|c|c|c|c|c|c|c|c|}
\hline Показатели & 2010 & 2011 & 2012 & 2013 & 2014 & 2015 & 2016 \\
\hline ТY, отн. ед & 1,001 & 1,005 & 1,014 & 1,019 & 1,022 & 1,018 & 1,012 \\
\hline$\Delta$ ТY, отн. ед. & - & 0,005 & 0,014 & 0,019 & 0,022 & 0,018 & 0,012 \\
\hline Сектор (по R) & - & 1 & 1 & 4 & 4 & 2 & 1 \\
\hline$\Delta \mathrm{R}^{\prime}$, отн. ед. & & $-0,078$ & $-0,086$ & $-0,038$ & $-0,003$ & 0,002 & $-0,154$ \\
\hline ТY, ${ }^{\prime}$ отн. ед. & & 1,005 & 1,019 & 1,038 & 1,061 & 1,080 & 1,093 \\
\hline$\Delta \mathrm{TY}^{\prime}$, отн. ед. & & 0,005 & 0,019 & 0,038 & 0,061 & 0,080 & 0,093 \\
\hline Сектор по $R^{\prime}$ & & 1 & 1 & 1 & 1 & 2 & 1 \\
\hline \multicolumn{8}{|c|}{ Новгородская область, Reea $=1,95$, Reea $^{\prime}=2,00$} \\
\hline R, тыс. тонн & 45,510 & 42,460 & 45,350 & 45,190 & 42,570 & 69,980 & 45,660 \\
\hline$\Delta \mathrm{R}$, отн. ед. & - & $-0,057$ & 0,073 & 0,003 & $-0,053$ & 0,655 & $-0,344$ \\
\hline ТY, отн. ед & 1,033 & 1,045 & 1,089 & 1,025 & 1,058 & 1,027 & 1,021 \\
\hline$\Delta$ ТY, отн. ед. & - & 0,045 & 0,089 & 0,025 & 0,058 & 0,027 & 0,021 \\
\hline Сектор (по R) & - & 1 & 2 & 2 & 1 & 4 & 1 \\
\hline$\Delta \mathrm{R}^{\prime}$, отн. ед. & & $-0,057$ & 0,012 & 0,015 & $-0,039$ & 0,590 & 0,042 \\
\hline TY', отн. ед. & & 1,045 & 1,138 & 1,166 & 1,234 & 1,267 & 1,294 \\
\hline$\Delta \mathrm{TY}^{\prime}$, отн. ед. & & 0,045 & 0,138 & 0,166 & 0,234 & 0,267 & 0,294 \\
\hline Секто & & 1 & 2 & 2 & 1 & 4 & 2 \\
\hline \multicolumn{8}{|c|}{ Псковская область, Reea $=3,05$, Reea $^{\prime}=4,00$} \\
\hline R, тыс. & 22,300 & 27,880 & 27,620 & 27,040 & 28,950 & 26,950 & 33,400 \\
\hline$\Delta \mathrm{R}$, отн. ед. & - & 0,271 & $-0,003$ & $-0,014$ & 0,079 & $-0,061$ & 0,249 \\
\hline TY, o & 1,071 & 1,077 & 1,008 & 1,013 & 1,003 & 0,988 & 1,014 \\
\hline$\Delta \mathrm{TY}$, & - & 0,077 & 08 & 0,013 & 0,003 & $-0,012$ & 0,014 \\
\hline Сектор & - & 4 & 1 & 1 & 4 & 3 & 4 \\
\hline$\Delta \mathrm{R}^{\prime}$, отн. ед. & & 0,271 & 0,266 & 0,249 & 0,348 & 0,266 & 0,581 \\
\hline ТY', отн. ед. & & 1,077 & 1,086 & 1,100 & 1,103 & 1,090 & 1,105 \\
\hline$\Delta \mathrm{TY}^{\prime}$, отн. ед. & & 0,077 & 0,086 & 0,100 & 0,103 & 0,090 & 0,105 \\
\hline Сектор по $R$ & & 4 & 4 & 4 & 4 & 4 & 4 \\
\hline \multicolumn{8}{|c|}{ Санкт-Петербург, Reea $=3,81$, Reea $^{\prime}=4,00$} \\
\hline R, тыс. тонн & 56,610 & 69,150 & 68,850 & 72,270 & 70,510 & 73,150 & 78,280 \\
\hline$\Delta \mathrm{R}$, отн. ед. & - & 0,205 & $-0,015$ & 0,034 & $-0,044$ & 0,025 & 0,063 \\
\hline TY, oT & 1,045 & 1,070 & 1,030 & 1,000 & 0,994 & 1,005 & 1,014 \\
\hline$\Delta \mathrm{TY}, \mathrm{o}$ & - & 0,070 & 0,030 & 0,000 & $-0,006$ & 0,005 & 0,014 \\
\hline Сектор (по R) & - & 4 & 1 & 6 & 3 & 4 & 4 \\
\hline$\Delta \mathrm{R}^{\prime}$, отн. ед. & & 0,205 & 0,187 & 0,227 & 0,173 & 0,203 & 0,279 \\
\hline TY', отн. ед. & & 1,070 & 1,102 & 1,102 & 1,095 & 1,101 & 1,116 \\
\hline$\Delta \mathrm{TY}^{\prime}$, отн. ед. & & 0,070 & 0,102 & 0,102 & 0,095 & 0,101 & 0,116 \\
\hline Сектор по $R$ & & 4 & 4 & 4 & 4 & 4 & 4 \\
\hline
\end{tabular}


Таблица А3

\section{Характеристика эффекта декаплинга (на примере регионов ЮФО)}

\begin{tabular}{|c|c|c|c|c|c|c|c|}
\hline Показатели & 2010 & 2011 & 2012 & 2013 & 2014 & 2015 & 2016 \\
\hline \multicolumn{8}{|c|}{ Республика Адыгея, Reea $=4,00$, Reea $^{\prime}=4,00$} \\
\hline R, тыс. тонн & 3,61 & 4,24 & 6,29 & 8,59 & 10,12 & 10,65 & 10,92 \\
\hline$\Delta \mathrm{R}$, отн. ед. & - & 0,175 & 0,473 & 0,360 & 0,175 & 0,045 & 0,021 \\
\hline ТY, отн. ед. & 1,043 & 1,053 & 1,054 & 1,023 & 1,033 & 1,002 & 1,014 \\
\hline$\Delta$ ТY, отн. ед. & - & 0,056 & 0,059 & 0,027 & 0,038 & 0,008 & 0,019 \\
\hline Сектор (по R) & - & 4 & 4 & 4 & 4 & 4 & 4 \\
\hline$\Delta \mathrm{R}^{\prime}$, отн. ед. & & 0,175 & 0,731 & 1,353 & 1,766 & 1,891 & 1,951 \\
\hline ТY', отн. ед. & & 1,053 & 1,110 & 1,135 & 1,173 & 1,175 & 1,192 \\
\hline$\Delta \mathrm{TY}^{\prime}$, отн. ед. & & 0,053 & 0,110 & 0,135 & 0,173 & 0,175 & 0,192 \\
\hline Сектор по $R^{\prime}$ & & 4 & 4 & 4 & 4 & 4 & 4 \\
\hline \multicolumn{8}{|c|}{ Астраханская область, Reea $=3,19$, Reea $=1,67$} \\
\hline R, тыс. тонн & 124,93 & 131,52 & 134,38 & 130,48 & 118,15 & 118,63 & 126,76 \\
\hline$\Delta \mathrm{R}$, отн. ед. & - & 0,054 & 0,017 & $-0,028$ & $-0,097$ & 0,000 & 0,071 \\
\hline TY, o & 1,021 & 1,076 & 1,111 & 1,161 & 1,001 & 0,990 & 1,029 \\
\hline$\Delta$ ТY, отн. ед. & - & 0,076 & 0,111 & 0,161 & 0,001 & $-0,010$ & 0,029 \\
\hline Сект & - & 2 & 2 & 1 & 1 & 6 & 4 \\
\hline$\Delta \mathrm{R}^{\prime}$ & & 0,054 & 0,071 & 0,041 & $-0,060$ & $-0,060$ & 0,007 \\
\hline $\mathrm{TY}^{\prime}, \mathrm{o}$ & & 1,076 & 1,195 & 1,388 & 1,389 & 1,375 & 1,415 \\
\hline$\Delta \mathrm{TY}^{\prime}$, отн. ед. & & 0,076 & 0,195 & 0,388 & 0,389 & 0,375 & 0,415 \\
\hline Сектор по $R^{\prime}$ & & 2 & 2 & 2 & 1 & 1 & 2 \\
\hline \multicolumn{8}{|c|}{ Волгоградская область, Reea $=3,76, \mathrm{Reea}^{\prime}=1,00$} \\
\hline $\mathrm{R}, \mathrm{ты}$ & 201,1 & 178,2 & 170,9 & 172,8 & 153,5 & 160 & 161,4 \\
\hline$\Delta \mathrm{R}$, отн. ед. & - & -0 , & $-0,037$ & 0,016 & $-0,107$ & 0,047 & 0,014 \\
\hline $\mathrm{TY}, \mathrm{o}$ & 1,039 & 1,037 & 1,033 & 1,019 & 1,052 & 0,943 & 0,990 \\
\hline$\Delta \mathrm{TY}$ & - & 0,037 & 0,033 & 0,019 & 0,052 & $-0,057$ & $-0,010$ \\
\hline Сектор (по R) & - & 1 & 1 & 2 & 1 & 6 & 6 \\
\hline$\Delta \mathrm{R}^{\prime}$, отн. ед. & & $-0,111$ & $-0,144$ & $-0,131$ & $-0,223$ & $-0,187$ & $-0,176$ \\
\hline TY', отн. ед. & & 1,037 & 1,071 & 1,092 & 1,148 & 1,083 & 1,072 \\
\hline$\Delta \mathrm{TY}^{\prime}$, отн. ед & & 0,037 & 0,071 & 0,092 & 0,148 & 0,083 & 0,072 \\
\hline Сектор по $R$ & & 1 & 1 & 1 & 1 & 1 & 1 \\
\hline \multicolumn{8}{|c|}{ Республика Калмыкия, Reea = 2,81, Reea $=2,83$} \\
\hline $\mathrm{R}, \mathrm{Tb}$ & 3,5 & 3,57 & 3,66 & 6,71 & 4,54 & 3,42 & 2,19 \\
\hline$\Delta \mathrm{R}$, отн. ед. & - & 0,024 & 0,032 & 0,853 & $-0,319$ & $-0,244$ & $-0,355$ \\
\hline ТY, отн. ед. & 0,966 & 1,027 & 1,008 & 1,034 & 1,053 & 0,965 & 0,986 \\
\hline$\Delta$ TY, отн. ед. & - & 0,027 & 0,008 & 0,034 & 0,053 & $-0,035$ & $-0,014$ \\
\hline Сектор (по R) & - & 2 & 4 & 4 & 1 & 3 & 3 \\
\hline$\Delta \mathrm{R}^{\prime}$, отн. ед. & & 0,024 & 0,057 & 0,958 & 0,334 & 0,008 & $-0,350$ \\
\hline TY, отн. ед. & & 1,027 & 1,035 & 1,070 & 1,127 & 1,088 & 1,072 \\
\hline$\Delta \mathrm{TY}^{\prime}$, отн. ед. & & 0,027 & 0,035 & 0,070 & 0,127 & 0,088 & 0,072 \\
\hline Сектор по $R^{\prime}$ & & 2 & 4 & 4 & 4 & 2 & 1 \\
\hline
\end{tabular}


Окончание таблицы $A 3$

\begin{tabular}{|c|c|c|c|c|c|c|c|}
\hline Показатели & 2010 & 2011 & 2012 & 2013 & 2014 & 2015 & 2016 \\
\hline \multicolumn{8}{|c|}{ Краснодарский край, Reea $=4,43$, Reea $=4,00$} \\
\hline R, тыс. тонн & 138,97 & 161,34 & 215,74 & 205,17 & 188,89 & 190,83 & 242,25 \\
\hline$\Delta \mathrm{R}$, отн. ед. & - & 0,157 & 0,324 & $-0,057$ & $-0,092$ & 0,001 & 0,256 \\
\hline ТY, отн. ед. & 1,059 & 1,069 & 1,027 & 1,028 & 0,996 & 0,974 & 0,990 \\
\hline$\Delta \mathrm{TY}$, отн. $\mathrm{e}$ & - & 0,069 & 0,027 & 0,028 & $-0,004$ & $-0,026$ & $-0,010$ \\
\hline Сектор (по R) & - & 4 & 4 & 1 & 3 & 6 & 6 \\
\hline$\Delta \mathrm{R}^{\prime}$, отн. ед. & & 0,157 & 0,532 & 0,444 & 0,311 & 0,313 & 0,648 \\
\hline $\mathrm{TY}^{\prime}$, & & 1,069 & 1,098 & 1,129 & 1,124 & 1,095 & 1,084 \\
\hline$\Delta \mathrm{TY}^{\prime}$, отн. ед. & & 0,069 & 0,098 & 0,129 & 0,124 & 0,095 & 0,084 \\
\hline Сектор по $R$ & & 4 & 4 & 4 & 4 & 4 & 4 \\
\hline \multicolumn{8}{|c|}{ Ростовская область, Reea $=2,62, \mathrm{Reea}^{\prime}=1,50$} \\
\hline R, тыс. тонн & 175,84 & 153,96 & 200,2 & 192,63 & 194,05 & 164,91 & 169,12 \\
\hline$\Delta \mathrm{R}$, отн. ед. & - & $-0,122$ & 0,305 & $-0,036$ & 0,009 & $-0,149$ & 0,027 \\
\hline TY, & 1,021 & 1,076 & 1,111 & 1,161 & 1,001 & 0,990 & 1,029 \\
\hline$\Delta \mathrm{TY}, \mathrm{OT}$ & - & 0,076 & 0,111 & 0,161 & 0,001 & $-0,010$ & 0,029 \\
\hline Сектор (по R) & - & 1 & 4 & 1 & 4 & 3 & 2 \\
\hline$\Delta \mathrm{R}^{\prime}$, отн. ед. & & $-0,122$ & 0,145 & 0,103 & 0,114 & $-0,053$ & $-0,027$ \\
\hline $\mathrm{TY}^{\prime}$, оTH & & 1,076 & 1,195 & 1,388 & 1,389 & 1,375 & 1,415 \\
\hline$\Delta \mathrm{TY}^{\prime}, \mathrm{o}$ & & 0,076 & 0,195 & 0,388 & 0,389 & 0,375 & 0,415 \\
\hline Сектор по $R$ & & 1 & 2 & 2 & 2 & 1 & 1 \\
\hline
\end{tabular}

Таблиияа $A 4$

\section{Характеристика эффекта декаплинга (на примере регионов СКФО)}

\begin{tabular}{|c|c|c|c|c|c|c|c|}
\hline Показатели & 2010 & 2011 & 2012 & 2013 & 2014 & 2015 & 2016 \\
\hline \multicolumn{8}{|c|}{ Республика Дагестан, Reea $=3,91$, Reea $=1,00$} \\
\hline R, тыс. тонн & 65,730 & 67,910 & 69,260 & 75,000 & 78,890 & 85,480 & 87,890 \\
\hline$\Delta R$, отн. ед. & - & 0,030 & 0,020 & 0,081 & 0,051 & 0,082 & 0,027 \\
\hline ТY, отн. ед & 1,042 & 1,065 & 1,005 & 1,027 & 1,041 & 1,008 & 1,003 \\
\hline$\Delta$ TY, отн. ед. & - & 0,065 & 0,005 & 0,027 & 0,041 & 0,008 & 0,003 \\
\hline Сектор (по R) & - & 2 & 4 & 4 & 4 & 4 & 4 \\
\hline$\Delta \mathrm{R}^{\prime}$, отн. ед. & & $-0,081$ & $-0,008$ & $-0,144$ & $-0,307$ & $-0,431$ & $-0,270$ \\
\hline ТY, отн. ед. & & 1,068 & 1,112 & 1,175 & 1,240 & 1,211 & 1,217 \\
\hline$\Delta \mathrm{TY}^{\prime}$, отн. ед. & & 0,068 & 0,112 & 0,175 & 0,240 & 0,211 & 0,217 \\
\hline Сектор по $R$ & & 1 & 1 & 1 & 1 & 1 & 1 \\
\hline \multicolumn{8}{|c|}{ Республика Ингушетия, Reea $=4,10$, Reea $^{\prime}=1,67$} \\
\hline R, тыс. тонн & 0,500 & 0,130 & 0,190 & 0,590 & 0,410 & 0,410 & 1,080 \\
\hline$\Delta \mathrm{R}$, отн. ед. & - & $-0,742$ & 0,411 & 2,021 & $-0,322$ & $-0,024$ & 1,584 \\
\hline ТY, отн. ед & 0,874 & 1,013 & 1,069 & 1,116 & 1,113 & 1,030 & 0,955 \\
\hline$\Delta$ TY, отн. ед. & - & 0,069 & 0,116 & 0,113 & 0,030 & $-0,045$ & $-0,045$ \\
\hline Сектор (по R) & - & 1 & 4 & 4 & 1 & 5 & 6 \\
\hline$\Delta R^{\prime}$, отн. ед. & & $-0,742$ & $-0,636$ & 0,100 & $-0,254$ & $-0,272$ & 0,881 \\
\hline TY, отн. ед. & & 1,069 & 1,193 & 1,328 & 1,368 & 1,306 & 1,247 \\
\hline$\Delta \mathrm{TY}^{\prime}$, отн. ед. & & 0,069 & 0,193 & 0,328 & 0,368 & 0,306 & 0,247 \\
\hline Сектор по $R$ & & 1 & 1 & 2 & 1 & 1 & 4 \\
\hline
\end{tabular}


Продолжение таблицы $A 4$

\begin{tabular}{|c|c|c|c|c|c|c|c|}
\hline Показатели & 2010 & 2011 & 2012 & 2013 & 2014 & 2015 & 2016 \\
\hline \multicolumn{8}{|c|}{ Кабардино-Балкарская Республика, Reea $=3,71$, Reea $^{\prime}=1,67$} \\
\hline R, тыс. тонн & 2,760 & 2,390 & 2,580 & 2,160 & 2,280 & 2,980 & 3,880 \\
\hline $\mathrm{R}$, отн. ед. & - & $-0,135$ & 081 & $-0,163$ & 0,056 &, 304 & 0,301 \\
\hline ТY, отн. ед & 1,054 & 041 & 558 & 88 & 015 & 017 & 023 \\
\hline$\Delta$ ТY, отн. ед. & - & 041 & 058 & $-0,012$ & 0,015 &, 017 &, 023 \\
\hline Сектор (по R) & - & 1 & 4 & & 4 & 4 & \\
\hline$\Delta \mathrm{R}^{\prime}$, отн. ед. & & $-0,135$ & $-0,065$ & $-0,217$ & $-0,174$ & 0,077 & 0,401 \\
\hline TY', отн. ед. & & 1,041 & 1,101 & 1,088 & 1,104 & 1,123 & 1,149 \\
\hline$\Delta$ TY$^{\prime}$, отн. ед. & & 0,041 & 0,101 & 0,088 & 0,104 & 0,123 & 0,149 \\
\hline Сектор по $R^{\prime}$ & & 1 & 1 & 1 & 1 & 2 & 4 \\
\hline \multicolumn{8}{|c|}{ Черкесская Республика, Reea $=3,14$, Reea $^{\prime}=1,83$} \\
\hline $\mathrm{R, \text {тыс }}$ & 20,140 & 25,490 & 22,210 & 21,070 & 15,740 & 14,700 & 17,200 \\
\hline$\overline{\Delta \mathrm{R}, \mathrm{c}}$ & - & & 25 & -0 , & $-0,250$ & $-0,064$ & 0,173 \\
\hline TY,o & 1,011 & 81 & & 0,996 & 0,983 &, 953 & 1,046 \\
\hline$\Delta \mathrm{TY}$ & - & 151 & 053 & $-0,004$ &, 017 & 0,047 & 0,046 \\
\hline Сектор (по R & - & 4 & 1 & 3 & 3 & 3 & 4 \\
\hline$\Delta \mathrm{R}^{\prime}$, отн. ед. & & 0,258 & 0,100 & 0,051 & $-0,212$ & $-0,262$ & $-0,135$ \\
\hline ТY', отн. ед. & & 1,051 & 1,107 & 1,102 & 1,084 & 1,033 & 1,080 \\
\hline$\Delta$ TY$^{\prime}$, отн. ед. & & 051 & 107 & 0,102 &, 084 & 0,033 & 0,080 \\
\hline Сектор по $R^{\prime}$ & & 4 & 2 & 2 & 1 & 1 & \\
\hline \multicolumn{8}{|c|}{ 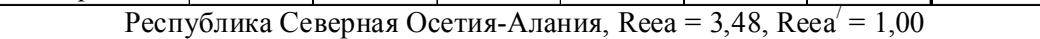 } \\
\hline R, тыс. тонн & 5,820 & 4,040 & 4,390 & 5,030 & 3,480 & 5,280 & 4,540 \\
\hline$\overline{\Delta \mathrm{R}, \mathrm{c}}$ & - & -0 , & & & $-0,306$ & 513 & $-0,138$ \\
\hline TY,o & 1,061 & & 20 & 1, & 1,016 & 0,974 & 0,957 \\
\hline$\Delta \mathrm{TY}$ & - & 31 & 20 & 0,040 & 0,016 & $-0,026$ & $-0,043$ \\
\hline Сектор (по R) & - & 1 & 4 & 4 & 1 & 6 & 3 \\
\hline$\Delta \mathrm{R}^{\prime}$, отн. ед. & & $-0,306$ & $-0,243$ & $-0,128$ & $-0,395$ & $-0,085$ & $-0,211$ \\
\hline ТY', отн. ед. & & 1,031 & 1,052 & 1,094 & 1,111 & 1,082 & 1,036 \\
\hline$\Delta \mathrm{TY}^{\prime}$, отн. ед. & & 0,031 & 0,052 & 0,094 & 0,111 & 0,082 & 0,036 \\
\hline ктор по $R$ & & 1 & 1 & 1 & 1 & 1 & \\
\hline \multicolumn{8}{|c|}{ Чеченская Республика, Reea $=2,57$, Reea $^{\prime}=1,50$} \\
\hline $\mathrm{R}, \mathrm{ты}$ & 25,050 & 20,2 & & 21,460 & 31,310 & 20,660 & 21,060 \\
\hline$\Delta \mathrm{R}, \mathrm{o}$ & - & & & & & & 0,002 \\
\hline TY,o & 0,943 & & & & 1,067 & 1,011 & 1,028 \\
\hline$\Delta \mathrm{TY}$ & - & 0,046 & 051 & $-0,015$ & 0,067 & 0,011 & 0,028 \\
\hline Секто & - & & 1 & 6 & 4 & 1 & 2 \\
\hline$\Delta \mathrm{R}^{\prime}, \mathrm{o}$ & & $-0,209$ & $-0,275$ & $-0,192$ & 0,161 & $-0,247$ & $-0,246$ \\
\hline $\mathrm{TY}^{\prime}$, отн. ед. & & 46 & 99 & 1 , & 1,155 & 1,168 & 1,201 \\
\hline$\Delta \mathrm{TY}^{\prime}, \mathrm{c}$ & & 0,046 & 0,099 & 0,083 & 0,155 & 0,168 & 0,201 \\
\hline nо $R$ & & 1 & 1 & 1 & 4 & & \\
\hline
\end{tabular}


Окончание таблицы $A 4$

\begin{tabular}{|c|c|c|c|c|c|c|c|}
\hline Показатели & 2010 & 2011 & 2012 & 2013 & 2014 & 2015 & 2016 \\
\hline \multicolumn{8}{|c|}{ Ставропольский край, Reea $=3,91$, Reea $^{\prime}=3,33$} \\
\hline $\mathrm{R}$, тыс. тонн & 65,730 & 67,910 & 69,260 & 75,000 & 78,890 & 85,480 & 87,890 \\
\hline$\Delta \mathrm{R}$, отн. ед. & $\begin{array}{ll}- \\
-\end{array}$ & 0,030 & 0,020 & 0,081 & 0,051 & 0,082 & 0,027 \\
\hline ТY, отн. ед & 1,042 & 1,065 & 1,005 & 1,027 & 1,041 & 1,008 & 1,003 \\
\hline$\Delta$ ТY, отн. ед. & - & 0,065 & 0,005 & 0,027 & 0,041 & 0,008 & 0,003 \\
\hline Сектор (по R) & - & 2 & 4 & 4 & 4 & 4 & 4 \\
\hline$\Delta \mathrm{R}^{\prime}$, отн. ед. & & 0,030 & 0,050 & 0,135 & 0,193 & 0,290 & 0,325 \\
\hline TY', отн. ед. & & 1,065 & 1,070 & 1,099 & 1,144 & 1,153 & 1,157 \\
\hline$\Delta \mathrm{TY}^{\prime}$, отн. ед. & & 0,065 & 0,070 & 0,099 & 0,144 & 0,153 & 0,157 \\
\hline Сектор по $R$ & & 2 & 2 & 4 & 4 & 4 & 4 \\
\hline
\end{tabular}

Таблицча $A 5$

\section{Характеристика эффекта декаплинга (на примере регионов ПриволжскогоФО)}

\begin{tabular}{|c|c|c|c|c|c|c|c|}
\hline Показатели & 2010 & 2011 & 2012 & 2013 & 2014 & 2015 & 2016 \\
\hline \multicolumn{8}{|c|}{ Республика Башкортостан, Reea $=3,38$, Reea $^{\prime}=3,00$} \\
\hline R, тыс. тонн & 387,59 & 406,44 & 402,83 & 448,94 & 459,37 & 434,91 & 460,89 \\
\hline$\triangle \mathrm{R}$, отн. ед. & - & 0,048 & $-0,007$ & 0,115 & 0,021 & $-0,054$ & 0,060 \\
\hline ТY, отн. ед & 1,050 & 1,083 & 1,045 & 1,025 & 1,018 & 0,983 & 1,006 \\
\hline$\Delta$ ТY, отн. ед. & - & 0,083 & 0,045 & 0,025 & 0,018 & $-0,017$ & 0,006 \\
\hline Сектор (по R) & - & 2 & 1 & 4 & 4 & 3 & 4 \\
\hline$\Delta \mathrm{R}^{\prime}$, отн. ед. & & 0,048 & 0,041 & 0,161 & 0,185 & 0,121 & 0,189 \\
\hline $\mathrm{TY}^{\prime}$, отн. ед. & & 1,083 & 1,132 & 1,160 & 1,181 & 1,161 & 1,168 \\
\hline$\Delta \mathrm{TY}^{\prime}$, отн. ед. & & 0,083 & 0,132 & 0,160 & 0,181 & 0,161 & 0,168 \\
\hline Сектор по $R^{\prime}$ & & 2 & 2 & 4 & 4 & 2 & 4 \\
\hline \multicolumn{8}{|c|}{ Республика Марий Эл, Reea = 2,71, Reea $=1,33$} \\
\hline $\mathrm{R}, \mathrm{Tb}$ & 32,64 & 28,66 & 34,46 & 26,87 & 24,62 & 22,35 & 36,44 \\
\hline$\Delta \mathrm{R}$, отн. ед. & - & $-0,117$ & 0,208 & $-0,218$ & $-0,081$ & $-0,091$ & 0,633 \\
\hline TY, & 1,060 & 1,065 & 1,102 & 1,022 & 1,062 & 1,034 & 0,949 \\
\hline$\triangle$ ТҮ, отн. ед. & - & 0,065 & 0,102 & 0,022 & 0,062 & 0,034 & $-0,051$ \\
\hline Сектор (по R) & - & 1 & 4 & 1 & 1 & 1 & 6 \\
\hline$\Delta \mathrm{R}^{\prime}$, отн. ед. & & $-0,117$ & 0,066 & $-0,166$ & $-0,234$ & $-0,303$ & 0,138 \\
\hline ТY', отн. ед. & & 1,065 & 1,174 & 1,199 & 1,274 & 1,317 & 1,250 \\
\hline$\triangle \mathrm{TY}^{\prime}$, отн. ед. & & 0,065 & 0,174 & 0,199 & 0,274 & 0,317 & 0,250 \\
\hline Сектор по $R$ & & 1 & 2 & 1 & 1 & 1 & 2 \\
\hline \multicolumn{8}{|c|}{ Республика Мордовия, Reea $=2,19$, Reea $^{\prime}=2,17$} \\
\hline $\mathrm{R}, \mathrm{Tb}$ & 34,05 & 34,17 & 49,91 & 36,30 & 34,96 & 31,76 & 40,54 \\
\hline$\Delta \mathrm{R}$, отн. ед. & - & 0,010 & 0,477 & $-0,267$ & $-0,029$ & $-0,088$ & 0,280 \\
\hline ТY, отн. ед & 1,048 & 1,094 & 1,021 & 1,025 & 1,081 & 1,011 & 1,036 \\
\hline$\Delta \mathrm{TY}, \mathrm{o}$ & - & 0,103 & 0,030 & 0,033 & 0,088 & 0,014 & 0,036 \\
\hline Сектор (по R) & - & 2 & 4 & 1 & 1 & 1 & 4 \\
\hline
\end{tabular}


Продолжение таблийы A5

\begin{tabular}{|c|c|c|c|c|c|c|c|}
\hline Показатели & 2010 & 2011 & 2012 & 2013 & 2014 & 2015 & 2016 \\
\hline$\Delta \mathrm{R}^{\prime}$, отн. ед. & & 0,010 & 0,491 & 0,092 & 0,061 & $-0,033$ & 0,238 \\
\hline TY', отн. ед. & & 1,103 & 1,136 & 1,174 & 1,277 & 1,295 & 1,341 \\
\hline$\Delta \mathrm{TY}^{\prime}$, отн. ед. & & 0,103 & 0,136 & 0,174 & 0,277 & 0,295 & 0,341 \\
\hline Сектор по $R^{\prime}$ & & 2 & 4 & 2 & 2 & 1 & 2 \\
\hline \multicolumn{8}{|c|}{ Республика Татарстан, Reea $=3,00,{ }^{\prime}$ Reea $=2,67$} \\
\hline R, тыс. тонн & 262,80 & 277,86 & 288,12 & 298,10 & 293,68 & 293,59 & 338,28 \\
\hline$\Delta \mathrm{R}$, отн. ед. & - & 0,056 & 0,033 & 0,029 & $-0,019$ & $-0,005$ & 0,148 \\
\hline ТY, отн. ед & 1,041 & 1,055 & 1,050 & 1,019 & 1,017 & 0,996 & 1,006 \\
\hline$\Delta$ ТY, отн. ед. & - & 0,055 & 0,050 & 0,019 & 0,017 & $-0,004$ & 0,006 \\
\hline Сектор (по R) & - & 4 & 2 & 4 & 1 & 3 & 4 \\
\hline$\Delta \mathrm{R}^{\prime}$, отн. ед. & & 0,056 & 0,091 & 0,123 & 0,102 & 0,097 & 0,259 \\
\hline TY, отн. ед. & & 1,055 & 1,108 & 1,129 & 1,148 & 1,143 & 1,150 \\
\hline$\Delta \mathrm{TY}^{\prime}$, отн. ед. & & 0,055 & 0,108 & 0,129 & 0,148 & 0,143 & 0,150 \\
\hline Сектор по $R^{\prime}$ & & 4 & 2 & 2 & 2 & 2 & 4 \\
\hline \multicolumn{8}{|c|}{ Удмуртская республика, Reea $=2,38$, Reea $=3,67$} \\
\hline $\mathrm{R}, \mathrm{Tb}$ & 101,03 & 103,84 & 172,48 & 171,91 & 175,82 & 147,94 & 146,84 \\
\hline$\Delta \mathrm{R}, \mathrm{c}$ & - & 0,031 & 0,663 & $-0,003$ & 0,023 & $-0,159$ & $-0,007$ \\
\hline TY, o & 1,050 & 1,050 & 1,034 & 1,027 & 1,010 & 0,998 & 1,017 \\
\hline$\Delta$ ТҮ, отн. ед. & - & 0,050 & 0,034 & 0,027 & 0,010 & $-0,002$ & 0,017 \\
\hline o R) & - & 2 & 4 & 1 & 4 & 3 & 1 \\
\hline$\Delta \mathrm{R}^{\prime}$, отн. ед. & & 0,031 & 0,715 & 0,709 & 0,749 & 0,471 & 0,461 \\
\hline $\mathrm{TY}^{\prime}, \mathrm{o}$ & & 1,050 & 1,086 & 1,115 & 1,126 & 1,124 & 1,143 \\
\hline$\Delta \mathrm{TY}^{\prime}, \mathrm{o}$ & & 0,050 & 0,086 & 0,115 & 0,126 & 0,124 & 0,143 \\
\hline Сектор & & 2 & 4 & 4 & 4 & 4 & 4 \\
\hline \multicolumn{8}{|c|}{ Чувашская республика, Reea $=2,62, \mathrm{Reea}^{\prime}=1,67$} \\
\hline $\mathrm{R}, \mathrm{Tb}$ & 31,40 & 27,58 & 32,72 & 29,430 & 35,88 & 26,87 & 25,34 \\
\hline$\Delta \mathrm{R}$, & - & $-0,1$ & 0,190 & $-0,098$ & 0,223 & $-0,250$ & $-0,056$ \\
\hline TY, c & 1,036 & 1,071 & 1,065 & 0,984 & 1,004 & 0,974 & 1,007 \\
\hline$\Delta \mathrm{TY}$ & - & 0,071 & 0,065 & $-0,016$ & 0,004 & $-0,026$ & 0,007 \\
\hline по R) & - & 1 & 4 & 3 & 4 & 3 & 1 \\
\hline$\Delta \mathrm{R}^{\prime}$, отн. ед. & & $-0,118$ & 0,050 & $-0,054$ & 57 & 32 & $-0,181$ \\
\hline $\mathrm{TY}^{\prime}$, & & 71 & 41 & 22 & 27 & 1,098 & 1,105 \\
\hline$\Delta \mathrm{TY}^{\prime}$, отн. ед. & & 0,071 & 0,141 & 0,122 & 0,127 & 0,098 & 0,105 \\
\hline Сект & & 1 & 2 & 1 & 4 & 1 & 7 \\
\hline \multicolumn{8}{|c|}{ Пермский край, Reea $=3,48$, Reea $=2,17$} \\
\hline $\mathrm{R}, \mathrm{Tb}$ & 24,620 & 375,160 & 343,650 & 367,990 & 312,490 & 298,600 & 308,910 \\
\hline$\Delta \mathrm{R}$, отн. ед. & - & 0,162 & $-0,083$ & 0,070 & $-0,151$ & $-0,045$ & 0,036 \\
\hline TY,o & 1,079 & 1,086 & 1,006 & 1,007 & 1,033 & 0,996 & 0,968 \\
\hline$\Delta \mathrm{TY}, \mathrm{OT}$ & - & 0,086 & 0,006 & 0,007 & 0,033 & $-0,004$ & $-0,032$ \\
\hline Сектор (по R) & - & 4 & 1 & 4 & 1 & 3 & 6 \\
\hline$\Delta \mathrm{R}^{\prime}$, отн. ед. & & 0,162 & 0,066 & 0,140 & $-0,033$ & $-0,076$ & $-0,043$ \\
\hline ТY, , отн. ед. & & 1,086 & 1,093 & 1,100 & 1,136 & 1,132 & 1,096 \\
\hline$\Delta \mathrm{TY}^{\prime}$, OT & & 0,086 & 0,093 & 0,100 & 0,136 & 0,132 & 0,096 \\
\hline Сектор по $R^{\prime}$ & & 4 & 2 & 4 & 1 & 1 & 1 \\
\hline
\end{tabular}


Продолжение таблииь А5

\begin{tabular}{|c|c|c|c|c|c|c|c|}
\hline Показатели & 2010 & 2011 & 2012 & 2013 & 2014 & 2015 & 2016 \\
\hline \multicolumn{8}{|c|}{ Кировская область, Reea $=3,62, \mathrm{Reea}^{\prime}=2,00$} \\
\hline R, тыс. тонн & 01,970 & 98,620 & 101,340 & 103,340 & 114,910 & 96,090 & 98,640 \\
\hline$\Delta \mathrm{R}$, отн. ед. & - & $-0,023$ & 0,036 & 0,027 & 0,119 & $-0,159$ & 0,032 \\
\hline ТY, отн. ед & 1,057 & 1,058 & 1,025 & 1,012 & 1,028 & 0,997 & 1,001 \\
\hline$\Delta$ ТY, отн. ед. & - & 0,058 & 0,025 & 0,012 & 0,028 & $-0,003$ & 0,001 \\
\hline Сектор (по R) & - & 1 & 4 & 4 & 4 & 3 & 4 \\
\hline$\Delta \mathrm{R}^{\prime}$, отн. ед. & & $-0,023$ & 0,013 & 0,040 & 0,163 & $-0,022$ & 0,009 \\
\hline ТY', отн. ед. & & 1,058 & 1,084 & 1,097 & 1,128 & 1,125 & 1,126 \\
\hline$\Delta \mathrm{TY}^{\prime}$, отн. ед. & & 0,058 & 0,084 & 0,097 & 0,128 & 0,125 & 0,126 \\
\hline Сектор по $R^{\prime}$ & & 1 & 2 & 2 & 4 & 1 & 2 \\
\hline \multicolumn{8}{|c|}{ Нижегородская область, Reea $=3,33$, Reea $^{\prime}=1,00$} \\
\hline R, тыс. тонн & 155,96 & 142,31 & 145,94 & 125,91 & 125,65 & 132,66 & 149,69 \\
\hline$\Delta \mathrm{R}$, отн. ед. & - & $-0,082$ & 0,029 & $-0,135$ & 0,001 & 0,059 & 0,132 \\
\hline ТY, отн. ед & 1,080 & 1,074 & 1,041 & 1,022 & 1,032 & 0,968 & 1,033 \\
\hline$\Delta$ ТҮ, отн. ед. & - & 0,074 & 0,041 & 0,022 & 0,032 & $-0,032$ & 0,033 \\
\hline Сектор (по R) & - & 1 & 2 & 1 & 2 & 6 & 4 \\
\hline$\Delta \mathrm{R}^{\prime}$, отн. ед. & & $-0,082$ & $-0,056$ & $-0,184$ & $-0,183$ & $-0,135$ & $-0,020$ \\
\hline $\mathrm{TY}^{\prime}, \mathrm{o}$ & & 1,074 & 1,118 & 1,143 & 1,179 & 1,141 & 1,179 \\
\hline$\Delta \mathrm{TY}^{\prime}, \mathrm{o}$ & & 0,074 & 0,118 & 0,143 & 0,179 & 0,141 & 0,179 \\
\hline Сектор & & 1 & 1 & 1 & 1 & 1 & 1 \\
\hline \multicolumn{8}{|c|}{ Оренбургская область, Reea $=4,43$, Reea $^{\prime}=2,00$} \\
\hline $\mathrm{R}, \mathrm{TH}$ & 616,52 & 657,54 & 757,41 & 512,81 & 410,57 & 490,21 & 512,07 \\
\hline$\Delta \mathrm{R}$, & - & 0,072 & 0,156 & $-0,320$ & 97 & 0,199 & 0,048 \\
\hline TY, & 1,048 & 1,056 & 1,029 & 1,026 & 0,997 & 0,964 & 0,994 \\
\hline$\Delta \mathrm{TY}, \mathrm{c}$ & - & 0,056 & 0,029 & 0,026 & $-0,003$ & $-0,036$ & $-0,006$ \\
\hline Сек & - & 4 & 4 & 1 & 3 & 6 & 6 \\
\hline$\Delta \mathrm{R}^{\prime}$ & & 0,072 & 0,239 & $-0,157$ & $-0,323$ & $-0,189$ & $-0,150$ \\
\hline $\mathrm{TY}^{\prime}, \mathrm{o}$ & & 1,056 & 1,087 & 1,115 & 1,112 & 1,072 & 1,065 \\
\hline$\Delta \mathrm{TY}^{\prime}$, & & 0,056 & 0,087 & 0,115 & 0,112 & 0,072 & 0,065 \\
\hline Сект & & 4 & 4 & 1 & 1 & 1 & 1 \\
\hline \multicolumn{8}{|c|}{ Пензенская область, Reea $=4,29$, Reea $^{\prime}=3,50$} \\
\hline $\mathrm{R}, \mathrm{T}$ & 22,49 & 36,82 & 21,77 & 28,40 & 33,48 & 38,86 & 44,48 \\
\hline$\Delta \mathrm{R}$, & - & 0,647 & $-0,406$ & 0,312 & 0,186 & 0,165 & 0,151 \\
\hline ТY, отн. ед & 1,023 & 1,086 & 1,073 & 1,052 & 1,040 & 1,043 & 0,975 \\
\hline$\Delta \mathrm{TY}$, & - & 0,086 & 0,073 & 0,052 & 0,040 & 0,043 & $-0,025$ \\
\hline Сектор (по R) & - & 4 & 1 & 4 & 4 & 4 & 6 \\
\hline$\Delta \mathrm{R}^{\prime}$, отн. ед. & & 0,647 & $-0,021$ & 0,284 & 0,523 & 0,774 & 1,041 \\
\hline $\mathrm{TY}^{\prime}, \mathrm{c}$ & & & 1,165 & 1,226 & 1,275 & 1,330 & 1,296 \\
\hline$\Delta \mathrm{TY}^{\prime}$, отн. ед. & & 0,086 & 0,165 & 0,226 & 0,275 & 0,330 & 0,296 \\
\hline Секто & & 4 & 1 & 4 & 4 & 4 & 4 \\
\hline \multicolumn{8}{|c|}{ Самарская область, Reea $=3,10, \mathrm{Reea}^{\prime}=1,00$} \\
\hline $\mathrm{R}, \mathrm{T}$ & 308,470 & 292,430 & 275,510 & 261,000 & 266,390 & 261,140 & 253,250 \\
\hline$\Delta \mathrm{R}$, отн. ед. & - & $-0,050$ & $-0,058$ & $-0,052$ & 0,021 & $-0,020$ & $-0,028$ \\
\hline ТY, отн. ед & 1,086 & 1,060 & 1,050 & 1,042 & 1,019 & 0,971 & 0,979 \\
\hline
\end{tabular}


Окончание таблицы A5

\begin{tabular}{|c|c|c|c|c|c|c|c|}
\hline Показатели & 2010 & 2011 & 2012 & 2013 & 2014 & 2015 & 2016 \\
\hline$\Delta$ ТY, отн. ед. & - & 0,060 & 0,050 & 0,042 & 0,019 & $-0,029$ & $-0,021$ \\
\hline Сектор (по R) & - & 1 & 1 & 1 & 4 & 5 & 3 \\
\hline$\Delta \mathrm{R}^{\prime}$, отн. ед. & & $-0,050$ & $-0,105$ & $-0,152$ & $-0,134$ & $-0,151$ & $-0,175$ \\
\hline ТY', отн. ед. & & 1,060 & 1,113 & 1,160 & 1,182 & 1,148 & 1,123 \\
\hline$\Delta \mathrm{TY}^{\prime}$, отн. ед. & & 0,060 & 0,113 & 0,160 & 0,182 & 0,148 & 0,123 \\
\hline Сектор по $R^{\prime}$ & & 1 & 1 & 1 & 1 & 1 & 1 \\
\hline \multicolumn{8}{|c|}{ Саратовская область, Reea $=2,48$, Reea $^{\prime}=3,33$} \\
\hline $\mathrm{R}$, тыс. тонн & 94,70 & 108,83 & 127,75 & 98,81 & 119,92 & 118,20 & 109,97 \\
\hline$\Delta \mathrm{R}$, отн. ед. & - & 0,157 & 0,179 & $-0,225$ & 0,217 & $-0,013$ & $-0,068$ \\
\hline ТY, отн. ед & 1,026 & 1,085 & 1,062 & 1,045 & 1,005 & 0,992 & 1,012 \\
\hline$\triangle$ ТY, отн. ед. & - & 0,085 & 0,062 & 0,045 & 0,005 & $-0,008$ & 0,012 \\
\hline Сектор (по R) & - & 4 & 4 & 1 & 4 & 3 & 1 \\
\hline$\Delta \mathrm{R}^{\prime}$, отн. ед. & & 0,157 & 0,363 & 0,057 & 0,286 & 0,269 & 0,183 \\
\hline ТY', отн. ед. & & 1,085 & 1,152 & 1,204 & 1,210 & 1,200 & 1,215 \\
\hline$\triangle \mathrm{TY}^{\prime}$, отн. ед. & & 0,085 & 0,152 & 0,204 & 0,210 & 0,200 & 0,215 \\
\hline Сектор по $R^{\prime}$ & & 4 & 4 & 2 & 4 & 4 & 2 \\
\hline \multicolumn{8}{|c|}{ Ульяновская область, Reea $=2,05$, Reea $^{\prime}=1,50$} \\
\hline R, тыс. тонн & 38,95 & 42,25 & 34,39 & 38,10 & 34,18 & 33,20 & 32,62 \\
\hline$\Delta \mathrm{R}$, отн. ед. & - & 0,095 & $-0,181$ & 0,115 & $-0,099$ & $-0,024$ & $-0,014$ \\
\hline ТY, отн. ед & 1,058 & 1,088 & 1,031 & 1,026 & 1,010 & 0,985 & 1,022 \\
\hline$\Delta$ ТY, отн. ед. & - & 0,088 & 0,031 & 0,026 & 0,010 & $-0,015$ & 0,022 \\
\hline Сектор (по R) & - & 4 & 1 & 4 & 1 & 3 & 1 \\
\hline$\Delta \mathrm{R}^{\prime}$, отн. ед. & & 0,095 & $-0,103$ & 0,000 & $-0,099$ & $-0,121$ & $-0,133$ \\
\hline TY, отн. ед. & & 1,088 & 1,122 & 1,151 & 1,162 & 1,145 & 1,170 \\
\hline$\Delta \mathrm{TY}^{\prime}$, отн. ед. & & 0,088 & 0,122 & 0,151 & 0,162 & 0,145 & 0,170 \\
\hline Сектор по $R^{\prime}$ & & 4 & 1 & 1 & 1 & 1 & 1 \\
\hline
\end{tabular}

Таблицุа Аб

Характеристика эффекта декаплинга (на примере регионов Уральского ФО)

\begin{tabular}{|c|c|c|c|c|c|c|c|}
\hline Показатели & 2010 & 2011 & 2012 & 2013 & 2014 & 2015 & 2016 \\
\hline \multicolumn{8}{|c|}{ Курганская область, Reea $=3,19$, Reea $^{\prime}=1,17$} \\
\hline R, тыс. тонн & 55,240 & 47,210 & 41,120 & 54,720 & 43,400 & 51,740 & 41,710 \\
\hline$\Delta \mathrm{R}$, отн. ед. & - & $-0,137$ & $-0,116$ & 0,346 & $-0,199$ & 0,202 & $-0,186$ \\
\hline ТY, отн. ед. & 0,984 & 1,081 & 0,973 & 1,039 & 0,980 & 0,983 & 1,027 \\
\hline$\Delta \mathrm{TY}, \mathrm{o}$ & - & 0,081 & $-0,027$ & 0,039 & $-0,020$ & $-0,017$ & 0,027 \\
\hline Сектор & - & 1 & 3 & 4 & 3 & 6 & 1 \\
\hline$\Delta R^{\prime}$, отн. ед. & & $-0,137$ & $-0,237$ & 0,026 & $-0,178$ & $-0,012$ & $-0,196$ \\
\hline ТY, отн. ед. & & 1,081 & 1,052 & 1,093 & 1,071 & 1,053 & 1,081 \\
\hline$\Delta \mathrm{TY}^{\prime}$, отн. ед. & & 0,081 & 0,052 & 0,093 & 0,071 & 0,053 & 0,081 \\
\hline Сектор по $R^{\prime}$ & & 1 & 1 & 2 & 1 & 1 & 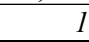 \\
\hline
\end{tabular}


Окончание таблицы А6

\begin{tabular}{|c|c|c|c|c|c|c|c|}
\hline Показатели & 2010 & 2011 & 2012 & 2013 & 2014 & 2015 & 2016 \\
\hline \multicolumn{8}{|c|}{ Свердловская область, Reea $=1,95$, Reea $=1,00$} \\
\hline R, тыс & 1169,040 & 1091,380 & 1129,080 & 1097,260 & 1021,160 & 983,920 & 906,360 \\
\hline$\Delta \mathrm{R}, \mathrm{c}$ & - & $-0,064$ & 0,032 & $-0,030$ & $-0,070$ & $-0,038$ & $-0,079$ \\
\hline ТY, отн. ед. & 1,116 & 1, & 1,069 & 1,018 & 1,000 & 0,972 & 1,019 \\
\hline$\Delta \mathrm{TY}$ & - & 0,089 & 0,069 & 0,018 & 0,000 & $-0,028$ & 0,019 \\
\hline Сектор (по R) & - & 1 & 2 & 1 & 3 & 3 & 1 \\
\hline$\Delta \mathrm{R}^{\prime}, \mathrm{o}$ & & $-0,064$ & $-0,034$ & $-0,063$ & $-0,129$ & $-0,162$ & $-0,229$ \\
\hline $\mathrm{TY}^{\prime}$, & & 89 & 1,164 & 1,185 & 1,185 & 1,152 & 1,174 \\
\hline$\Delta \mathrm{TY}^{\prime}$, отн. ед. & & 0,089 & 0,164 & 0,185 & 0,185 & 0,152 & 0,174 \\
\hline Секто & & 1 & 1 & 1 & 1 & 1 & 1 \\
\hline \multicolumn{8}{|c|}{ Тюменская область, Reea $=3,91$, Reea $^{\prime}=3,00$} \\
\hline $\mathrm{R}, \mathrm{Tb}$ & 3131,560 & 3293,440 & 3519,780 & 2750,580 & 2181,460 & 2145,810 & 2291,670 \\
\hline$\Delta \mathrm{R}, \mathrm{c}$ & - & 0,044 & & $-0,230$ & $-0,215$ & $-0,026$ & 0,058 \\
\hline TY, o & 1,052 & 1,019 & 0,983 & 1,012 & 0,971 & 0,982 & 0,994 \\
\hline$\Delta \mathrm{TY}$ & - & 0,019 & $-0,017$ & 0,012 & $-0,029$ & $-0,018$ & $-0,006$ \\
\hline Сект & - & 4 & 6 & 1 & 3 & 3 & 6 \\
\hline$\Delta \mathrm{R}^{\prime}$ & & 0,044 & 0,098 & $-0,155$ & $-0,336$ & $-0,353$ & $-0,316$ \\
\hline $\mathrm{TY}^{\prime}, \mathrm{c}$ & & 1,019 & 1,002 & 1,014 & 0,984 & 0,967 & 0,961 \\
\hline$\Delta \mathrm{TY}^{\prime}$ & & 0,019 & 0,002 & 0,014 & $-0,016$ & $-0,033$ & $-0,039$ \\
\hline Сект & & 4 & 4 & 1 & 3 & 3 & 3 \\
\hline \multicolumn{8}{|c|}{ Челябинская область, Reea $=2,05$, Reea $^{\prime}=1,00$} \\
\hline $\mathrm{R}, \mathrm{Tb}$ & 748,880 & 693,760 & 677,960 & 666,720 & 653,410 & 626,890 & 597,480 \\
\hline$\Delta \mathrm{R}$, отн. ед. & - & $-0,072$ & $-0,024$ & $-0,018$ & $-0,021$ & $-0,043$ & $-0,048$ \\
\hline $\mathrm{TY}, \mathrm{o}$ & 1,061 & 1,053 & 1,023 & 1,014 & 1,026 & 0,993 & 0,968 \\
\hline$\Delta \mathrm{TY}, \mathrm{o}$ & - & 0,053 & 0,023 & 0,014 & 0,026 & $-0,007$ & $-0,032$ \\
\hline Сектор (по R) & - & 1 & 1 & 1 & 1 & 3 & 3 \\
\hline$\Delta \mathrm{R}^{\prime}$, отн. ед. & & $-0,072$ & $-0,094$ & $-0,110$ & $-0,129$ & $-0,167$ & $-0,206$ \\
\hline $\mathrm{TY}^{\prime}$, & & 53 & 77 & 1,092 & 1,121 & 1,113 & 1,077 \\
\hline$\Delta \mathrm{TY}^{\prime}$, отн. ед. & & 0,053 & 0,077 & 0,092 & 0,121 & 0,113 & 0,077 \\
\hline Сектор по $R$ & & 1 & 1 & 1 & 1 & 1 & 1 \\
\hline
\end{tabular}

Таблицьа $A 7$

\section{Характеристика эффекта декаплинга \\ (на примере регионов Сибирского ФО)}

\begin{tabular}{|c|c|c|c|c|c|c|c|}
\hline Показатели & 2010 & 2011 & 2012 & 2013 & 2014 & 2015 & 2016 \\
\hline \multicolumn{8}{|c|}{ Республика Алтай, Reea = 3,52, Reea $=4,67$} \\
\hline $\mathrm{R}$, тыс. тонн & 6,130 & 8,750 & 9,100 & 9,200 & 8,070 & 8,220 & 7,120 \\
\hline$\Delta \mathrm{R}$, отн. ед. & - & 0,414 & 0,030 & 0,006 & $-0,127$ & 0,004 & $-0,138$ \\
\hline ТY, отн. ед. & 1,004 & 1,020 & 0,979 & 0,995 & 1,075 & 0,994 & 1,023 \\
\hline$\Delta \mathrm{TY}$, & - & 0,020 & $-0,021$ & $-0,005$ & 0,075 & $-0,006$ & 0,023 \\
\hline Сект & - & 4 & 6 & 6 & 1 & 6 & 1 \\
\hline$\Delta \mathrm{R}^{\prime}$, отн. ед. & & 0,414 & 0,456 & 0,465 & 0,279 & 0,285 & 0,107 \\
\hline
\end{tabular}


Продолжение таблицы A7

\begin{tabular}{|c|c|c|c|c|c|c|c|}
\hline Показатели & 2010 & 2011 & 2012 & 2013 & 2014 & 2015 & 2016 \\
\hline ТY', отн. ед. & & 1,020 & 0,999 & 0,994 & 1,068 & 1,062 & 1,086 \\
\hline$\triangle \mathrm{TY}^{\prime}$, отн. ед. & & 0,020 & $-0,001$ & $-0,006$ & 0,068 & 0,062 & 0,086 \\
\hline Сектор по $R^{\prime}$ & & 4 & 6 & 6 & 4 & 4 & 4 \\
\hline \multicolumn{8}{|c|}{ Республика Бурятии, Reea $=3,86$, Reea $^{\prime}=3,67$} \\
\hline $\mathrm{R}$, тыс. тонн & 95,180 & 90,060 & 99,750 & 114,070 & 105,930 & 108,520 & 94,330 \\
\hline$\Delta \mathrm{R}$, отн. ед. & - & $-0,056$ & 0,109 & 0,142 & $-0,073$ & 0,020 & $-0,134$ \\
\hline ТY, отн. ед. & 1,032 & 1,037 & 1,005 & 1,007 & 0,980 & 0,992 & 0,932 \\
\hline$\triangle$ ТY, отн. ед. & - & 0,037 & 0,005 & 0,007 & $-0,020$ & $-0,008$ & $-0,068$ \\
\hline Сектор (по R) & - & 1 & 4 & 4 & 3 & 6 & \\
\hline$\Delta \mathrm{R}^{\prime}$, отн. ед. & & $-0,056$ & \begin{tabular}{l|l}
0,047 \\
\end{tabular} & 0,196 & 0,108 & 0,131 & $-0,021$ \\
\hline ТY, отн. ед. & & 1,037 & 1,042 & 1,049 & 1,028 & 1,020 & 0,951 \\
\hline$\Delta \mathrm{TY}^{\prime}$, отн. ед. & & 0,037 & 0,042 & 0,049 & 0,028 & 0,020 & $-0,049$ \\
\hline Сектор по $R^{\prime}$ & & 1 & 4 & 4 & 4 & 4 & 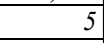 \\
\hline \multicolumn{8}{|c|}{ Республика Тыва, Reea $=2,48$, Reea $^{\prime}=1,00$} \\
\hline $\mathrm{R}$, тыс. тонн & 22,550 & 19,150 & 19,560 & 18,900 & 18,800 & 19,710 & 19,500 \\
\hline$\Delta \mathrm{R}, \mathrm{o}$ & - & $-0,154$ & 0,018 & $-0,037$ & $-0,012$ & 0,042 & $-0,017$ \\
\hline TY,o & 1,037 & 1,006 & 1,017 & 1,006 & 1,041 & 0,980 & 1,003 \\
\hline$\Delta$ ТY, отн. ед. & - & 0,006 & 0,017 & 0,006 & 0,041 & $-0,020$ & 0,003 \\
\hline Сектор (по R) & - & 1 & 4 & 1 & 1 & & 7 \\
\hline$\Delta \mathrm{R}^{\prime}$, отн. ед. & & $-0,154$ & $-0,138$ & $-0,170$ & $-0,180$ & $-0,145$ & $-0,160$ \\
\hline ТY, отн. ед. & & 1,006 & 1,023 & 1,029 & 1,071 & 1,050 & 1,053 \\
\hline$\triangle \mathrm{TY}^{\prime}$, отн. ед. & & 0,006 & 0,023 & 0,029 & 0,071 & 0,050 & 0,053 \\
\hline Сект & & 1 & 1 & 1 & 1 & 1 & \\
\hline \multicolumn{8}{|c|}{ Республика Хакасия, Reea $=3,14$, Reea $^{\prime}=1,00$} \\
\hline $\mathrm{R}, \mathrm{Tb}$ & 96,090 & 89,660 & 93,880 & 90,400 & 83,730 & 89,010 & 91,880 \\
\hline$\Delta \mathrm{R}, \mathrm{o}$ & - & $-0,065$ & 0,047 & $-0,039$ & $-0,076$ & 0,059 & 0,030 \\
\hline TY,o & 1,022 & 1,052 & 1,053 & 1,038 & 1,016 & 0,982 & 1,013 \\
\hline$\Delta \mathrm{TY}$ & - & 0,052 & 0,053 & 0,038 & 0,016 & $-0,018$ & 0,013 \\
\hline Секто & - & 1 & 2 & 1 & 1 & 0 & \\
\hline$\Delta \mathrm{R}^{\prime}$, отн. ед. & & $-0,065$ & $-0,021$ & $-0,059$ & $-0,130$ & $-0,079$ & $-0,051$ \\
\hline ТY', отн. ед. & & 1,052 & 1,108 & 1,150 & 1,168 & 1,147 & 1,162 \\
\hline$\Delta \mathrm{TY}^{\prime}$, отн. $\mathrm{e}$ & & 0,052 & 0,108 & 0,150 & 0,168 & 0,147 & 0,162 \\
\hline Секп & & 1 & 1 & 1 & 1 & 1 & \\
\hline \multicolumn{8}{|c|}{ Алтайский край, Reea $=4,00, \operatorname{Reea}^{\prime}=1,50$} \\
\hline $\mathrm{R}$, тыс. тонн & 207,230 & 203,630 & 216,450 & 201,250 & 203,110 & 204,460 & 213,280 \\
\hline$\Delta \mathrm{R}, \mathrm{c}$ & - & $-0,012$ & 0,067 & $-0,067$ & 0,013 & 0,009 & 0,047 \\
\hline ТY, отн. ед. & 1,036 & 1,044 & 1,020 & 1,052 & 1,007 & 1,008 & 0,994 \\
\hline$\triangle$ ТY, отн. ед. & - & 0,044 & 0,020 & 0,052 & 0,007 & 0,008 & $-0,006$ \\
\hline Сектор (по R) & - & 1 & 4 & 1 & 4 & 4 & 0 \\
\hline$\Delta \mathrm{R}^{\prime}$, отн. ед. & & $-0,012$ & o,055 & $-0,016$ & $-0,003$ & 0,006 & 0,053 \\
\hline ТY, отн. ед. & & 1,044 & 1,065 & 1,120 & 1,128 & 1,137 & 1,130 \\
\hline$\triangle \mathrm{TY}^{\prime}$, отн. ед. & & 0,044 & 0,065 & 0,120 & 0,128 & 0,137 & 0,130 \\
\hline Сектор по $R$ & & 1 & 2 & 1 & 1 & 2 & 2 \\
\hline \multicolumn{8}{|c|}{ Забайкальский край, Reea $=3,81$, Reea $^{\prime}=1,00$} \\
\hline $\mathrm{R}, \mathrm{Tb}$ & 138,160 & 130,920 & 127,190 & 127,070 & 124,540 & 119,200 & 121,730 \\
\hline$\Delta \mathrm{R}$, отн. ед. & - & $-0,050$ & $-0,023$ & 0,004 & $-0,015$ & $-0,040$ & 0,025 \\
\hline
\end{tabular}


Продолжение таблицьь A7

\begin{tabular}{|c|c|c|c|c|c|c|c|}
\hline Показатели & 2010 & 2011 & 2012 & 2013 & 2014 & 2015 & 2016 \\
\hline ТY, отн. ед. & 1,038 & 1,082 & 1,027 & 0,985 & 0,946 & 0,994 & 1,005 \\
\hline$\triangle$ ТҮ, отн. ед. & - & 0,082 & 0,027 & $-0,015$ & $-0,054$ & $-0,006$ & 0,005 \\
\hline Сектор (по R) & - & 1 & 1 & 6 & 5 & 3 & 4 \\
\hline$\Delta \mathrm{R}^{\prime}$, отн. ед. & & $-0,050$ & $-0,072$ & $-0,069$ & $-0,083$ & $-0,120$ & $-0,098$ \\
\hline ТY', отн. ед. & & 1,082 & 1,111 & 1,095 & 1,035 & 1,029 & 1,034 \\
\hline$\triangle \mathrm{TY}^{\prime}$, отн. ед. & & 0,082 & 0,111 & 0,095 & 0,035 & 0,029 & 0,034 \\
\hline Сектор по $R^{\prime}$ & & 1 & 1 & 1 & 1 & 1 & \\
\hline \multicolumn{8}{|c|}{ Красноярский край, Reea $=2,33$, Reea $=1,33$} \\
\hline $\mathrm{R}$, тыс. тонн & 2490,950 & 2516,810 & 2582,680 & 2497,280 & 2355,780 & 2475,890 & 2363,320 \\
\hline$\Delta R$, отн. ед. & - & 0,012 & 0,023 & $-0,036$ & $-0,059$ & 0,049 & $-0,048$ \\
\hline ТY, отн. ед. & 1,059 & 1,056 & 1,055 & 1,026 & 1,008 & 0,976 & 1,012 \\
\hline$\Delta$ ТY, отн. ед. & - & 0,056 & 0,055 & 0,026 & 0,008 & $-0,024$ & 0,012 \\
\hline Cектор (по R) & - & 2 & 2 & 1 & 1 & 6 & 1 \\
\hline$\Delta \mathrm{R}^{\prime}$, отн. ед. & & 0,012 & 0,035 & $-0,002$ & $-0,061$ & $-0,015$ & $-0,062$ \\
\hline ТY, отн. ед. & & 1,056 & 1,114 & 1,143 & 1,152 & 1,125 & 1,138 \\
\hline$\triangle \mathrm{TY}^{\prime}$, отн. ед. & & 0,056 & 0,114 & 0,143 & 0,152 & 0,125 & 0,138 \\
\hline Сектор по $R^{\prime}$ & & 2 & 2 & 1 & 1 & 1 & 1 \\
\hline \multicolumn{8}{|c|}{ Иркутская область, Reea $=1,86$, Reea $^{\prime}=2,33$} \\
\hline $\mathrm{R}, \mathrm{Tb}$ & 597,240 & 621,360 & 720,340 & 685,880 & 637,420 & 638,910 & 641,840 \\
\hline$\Delta \mathrm{R}, \mathrm{c}$ & - & 0,046 & 0,161 & $-0,047$ & $-0,069$ & 0,004 & 0,005 \\
\hline ТY, отн. ед. & 1,072 & 1,048 & 1,095 & 1,021 & 1,049 & 1,005 & 1,029 \\
\hline$\triangle$ ТҮ, отн. ед. & - & 0,048 & 0,095 & 0,021 & 0,049 & 0,005 & 0,029 \\
\hline Сектор (по R) & - & 2 & 4 & 1 & 1 & 2 & 2 \\
\hline$\Delta \mathrm{R}^{\prime}$, отн. ед. & & 0,046 & 0,214 & 0,157 & 0,077 & 0,081 & 0,087 \\
\hline TY, отн. ед. & & 1,048 & 1,148 & 1,172 & 1,229 & 1,235 & 1,271 \\
\hline$\triangle \mathrm{TY}^{\prime}$, отн. ед. & & 0,048 & 0,148 & 0,172 & 0,229 & 0,235 & 0,271 \\
\hline no $R$ & & 2 & 4 & 2 & 2 & 2 & 2 \\
\hline \multicolumn{8}{|c|}{ Кемеровская область, Reea $=4,71$, Reea $=3,67$} \\
\hline R, тыс. тонн & 1410,650 & 1390,030 & 1360,360 & 1356,300 & 1331,690 & 1344,460 & 1349,480 \\
\hline$\Delta \mathrm{R}$, отн. ед. & - & $-0,010$ & $-0,018$ & 0,000 & $-0,015$ & 0,013 & 0,006 \\
\hline ТY, отн. ед. & 1,030 & 1,027 & 0,961 & 0,963 & 1,024 & 0,993 & 0,973 \\
\hline$\triangle$ ТҮ, отн. ед. & - & 0,027 & $-0,039$ & $-0,037$ & 0,024 & $-0,007$ & $-0,027$ \\
\hline (по R) & - & 1 & 5 & 6 & 1 & 6 & 0 \\
\hline$\Delta \mathrm{R}^{\prime}, \mathrm{c}$ & & $-0,010$ & $-0,028$ & $-0,028$ & $-0,043$ & $-0,030$ & $-0,024$ \\
\hline TY, отн. ед. & & 1,027 & 0,987 & 0,950 & 0,973 & 0,966 & 0,940 \\
\hline$\triangle \mathrm{TY}^{\prime}$, отн. ед. & & 0,027 & $-0,013$ & $-0,050$ & $-0,027$ & $-0,034$ & $-0,060$ \\
\hline Сектор по $R$ & & 1 & 3 & 5 & 3 & 5 & 5 \\
\hline \multicolumn{8}{|c|}{ Новосибирская область, Reea $=2,95$, Reea $^{\prime}=1,17$} \\
\hline $\mathrm{R}, \mathrm{Tb}$ & 228,360 & 233,950 & 224,530 & 195,710 & 207,800 & 184,680 & 200,990 \\
\hline$\Delta \mathrm{R}, \mathrm{c}$ & - & 0,023 & $-0,048$ & $-0,136$ & 0,054 & $-0,116$ & 0,082 \\
\hline ТY, отн. ед. & 1,043 & 1,079 & 1,007 & 1,042 & 1,018 & 0,974 & 1,005 \\
\hline$\triangle$ ТҮ, отн. ед. & - & 0,079 & 0,007 & 0,042 & 0,018 & $-0,026$ & 0,005 \\
\hline Сектор (по R) & - & 2 & 1 & 1 & 4 & 3 & 4 \\
\hline$\Delta \mathrm{R}^{\prime}$, отн. ед. & & 0,023 & $-0,026$ & $-0,158$ & $-0,113$ & $-0,216$ & $-0,152$ \\
\hline ТY, отн. ед. & & 1,079 & 1,087 & 1,132 & 1,153 & 1,123 & 1,128 \\
\hline$\triangle \mathrm{TY}^{\prime}$, отн. ед. & & 0,079 & 0,087 & 0,132 & 0,153 & 0,123 & 0,128 \\
\hline Сектор по $R$ & & 2 & 1 & 1 & 1 & 1 & $c_{1}$ \\
\hline
\end{tabular}


Окончание таблицы А7

\begin{tabular}{|c|c|c|c|c|c|c|c|}
\hline Показатели & 2010 & 2011 & 2012 & 2013 & 2014 & 2015 & 2016 \\
\hline \multicolumn{8}{|c|}{ Омская область, Reea $=3,43$, Reea $=1,33$} \\
\hline $\mathrm{R}$, тыс. тонн & 229,920 & 235,850 & 240,160 & 213,610 & 203,950 & 201,510 & 199,970 \\
\hline$\Delta R$, отн. ед. & - & 0,029 & 0,019 & $-0,110$ & $-0,045$ & $-0,014$ & $-0,008$ \\
\hline ТY, отн. ед. & 1,030 & 1,063 & 1,019 & 1,051 & 1,019 & 0,969 & 0,986 \\
\hline$\Delta$ ТY, отн. ед. & - & 0,063 & 0,019 & 0,051 & 0,019 & $-0,031$ & $-0,014$ \\
\hline Сектор (по R) & - & 2 & 4 & 1 & 1 & 5 & 5 \\
\hline$\Delta \mathrm{R}^{\prime}$ & & 0,029 & 0,049 & $-0,066$ & $-0,108$ & $-0,121$ & $-0,128$ \\
\hline $\mathrm{TY}^{\prime}$, & & 1,063 & 1,083 & 1,138 & 1,160 & 1,124 & 1,108 \\
\hline$\triangle \mathrm{TY}^{\prime}$, отн. ед. & & 0,063 & 0,083 & 0,138 & 0,160 & 0,124 & 0,108 \\
\hline Сектор по $R$ & & 2 & 2 & 1 & 1 & 1 & \\
\hline \multicolumn{8}{|c|}{ Томская область, Reea $=3,10$, Reea $=1,50$} \\
\hline$\overline{\mathrm{R}, \text { ты }}$ & 345,250 & 378,910 & 322,630 & 306,100 & 289,630 & 293,080 & 301,360 \\
\hline$\Delta \mathrm{R}, \mathrm{o}$ & - & 0,088 & $-0,156$ & $-0,057$ & $-0,059$ & 0,008 & 0,025 \\
\hline ТҮ, отн. ед. & 1,039 & 1,028 & 1,029 & 1,012 & 0,997 & 1,001 & 1,007 \\
\hline$\Delta \mathrm{TY}$, отн. е & - & 0,028 & 0,029 & 0,012 & $-0,003$ & 0,001 & 0,007 \\
\hline Сектор (по R) & - & 4 & 1 & 1 & 3 & 4 & 4 \\
\hline$\Delta \mathrm{R}^{\prime}$, отн. ед. & & 0,088 & $-0,081$ & $-0,133$ & $-0,185$ & $-0,178$ & $-0,157$ \\
\hline $\mathrm{TY}^{\prime}, \mathrm{o}$ & & 1,028 & 1,058 & 1,071 & 1,067 & 1,068 & 1,076 \\
\hline$\Delta \mathrm{TY}^{\prime}, \mathrm{o}$ & & 0,028 & 0,058 & 0,071 & 0,067 & 0,068 & 0,076 \\
\hline Сектор по $R$ & & 4 & 1 & 1 & 1 & 1 & \\
\hline
\end{tabular}

Таблиияа $A 8$

Характеристика эффекта декаплинга (на примере регионов Дальневосточного ФО)

\begin{tabular}{|c|c|c|c|c|c|c|c|}
\hline Показатели & 2010 & 2011 & 2012 & 2013 & 2014 & 2015 & 2016 \\
\hline \multicolumn{8}{|c|}{ Республика Саха (Якутия), Reea $=2,10 ;$ Reea $^{\prime}=2,83$} \\
\hline R, тыс. тонн & 161,050 & 156,520 & 160,800 & 165,140 & 307,390 & 286,560 & 256,580 \\
\hline$\triangle \mathrm{R}$, отн. ед. & - & $-0,027$ & 0,029 & 0,027 & 0,863 & $-0,070$ & $-0,107$ \\
\hline ТY, отн. ед & 1,016 & 1,072 & 1,033 & 1,010 & 1,031 & 1,014 & 1,037 \\
\hline$\triangle$ ТY, отн. ед. & - & 0,072 & 0,033 & 0,010 & 0,031 & 0,014 & 0,037 \\
\hline Сектор (по R) & - & 1 & 2 & 4 & 4 & 1 & 1 \\
\hline$\Delta \mathrm{R}^{\prime}$, отн. ед. & & $-0,027$ & 0,002 & 0,029 & 0,917 & 0,783 & 0,592 \\
\hline TY', отн. ед. & & 1,072 & 1,107 & 1,118 & 1,153 & 1,169 & 1,213 \\
\hline$\triangle \mathrm{TY}^{\prime}$, отн. ед. & & 0,072 & 0,107 & 0,118 & 0,153 & 0,169 & 0,213 \\
\hline Сектор по $R^{\prime}$ & & 1 & 2 & 2 & 4 & 4 & 4 \\
\hline \multicolumn{8}{|c|}{ Камчатский край, Reea $=3,14$, Reea $^{\prime}=1,00$} \\
\hline $\mathrm{R}, \mathrm{Tb}$ & 36,840 & 30,840 & 34,380 & 32,720 & 23,360 & 24,820 & 28,610 \\
\hline$\Delta \mathrm{R}, \mathrm{o}$ & - & $-0,160$ & 0,122 & $-0,048$ & $-0,286$ & 0,073 & 0,156 \\
\hline ТY, отн. ед & 1,000 & 1,040 & 1,024 & 0,995 & 1,014 & 1,025 & 1,036 \\
\hline$\triangle \mathrm{TY}$, отн. ед. & - & 0,040 & 0,024 & $-0,005$ & 0,014 & 0,025 & 0,036 \\
\hline Секто & - & 1 & 4 & 3 & 1 & 4 & 4 \\
\hline$\Delta R^{\prime}$, отн. ед. & & $-0,160$ & $-0,058$ & $-0,104$ & $-0,360$ & $-0,314$ & $-0,206$ \\
\hline ТY', отн. ед. & & 1,040 & 1,065 & 1,060 & 1,074 & 1,101 & 1,141 \\
\hline$\Delta \mathrm{TY}^{\prime}$, отн. ед. & & 0,040 & 0,065 & 0,060 & 0,074 & 0,101 & 0,141 \\
\hline Сектор по $R^{\prime}$ & & 1 & 1 & 1 & 1 & 1 & 1 \\
\hline
\end{tabular}


Продолжение таблицьь $A 8$

\begin{tabular}{|c|c|c|c|c|c|c|c|}
\hline Показатели & 2010 & 2011 & 2012 & 2013 & 2014 & 2015 & 2016 \\
\hline \multicolumn{8}{|c|}{ Приморский Край, Reea = 4,05, Reea $=2,50$} \\
\hline $\mathrm{R}$, тыс. тонн & 232,780 & 224,920 & 208,730 & 180,910 & 189,520 & 192,950 & 186,250 \\
\hline$\Delta \mathrm{R}$, отн. ед. & - & 0,020 & $-0,042$ & $-0,128$ & 0,049 & 0,020 & $-0,030$ \\
\hline ТY, отн. ед & 1,121 & 1,077 & 0,933 & 0,977 & 1,017 & 0,997 & 0,980 \\
\hline$\triangle \mathrm{TY}$, отн. ед. & - & 0,077 & $-0,067$ & $-0,023$ & 0,017 & $-0,003$ & $-0,020$ \\
\hline Сектор (по R) & - & 2 & 5 & 3 & 4 & 6 & 3 \\
\hline$\Delta \mathrm{R}^{\prime}$, отн. ед. & & 0,020 & $-0,023$ & $-0,148$ & $-0,107$ & $-0,089$ & $-0,116$ \\
\hline ТY, отн. ед. & & 1,077 & 1,005 & 0,982 & 0,998 & 0,995 & 0,976 \\
\hline$\triangle \mathrm{TY}^{\prime}$, отн. ед. & & 0,077 & 0,005 & $-0,018$ & $-0,002$ & $-0,005$ & $-0,024$ \\
\hline Сектор по $R^{\prime}$ & & 2 & 1 & 3 & 3 & 3 & 3 \\
\hline \multicolumn{8}{|c|}{ Хабаровский край, Reea $=2,48$, Reea $^{\prime}=1,00$} \\
\hline R, тыс. тонн & 117,150 & 112,670 & 114,870 & 114,310 & 103,320 & 115,760 & 113,800 \\
\hline$\Delta \mathrm{R}$, отн. ед. & - & $-0,034$ & 0,020 & $-0,005$ & $-0,095$ & 0,122 & $-0,014$ \\
\hline ТY, отн. ед & 1,113 & 1,028 & 1,005 & 1,014 & 1,011 & 0,959 & 1,003 \\
\hline$\triangle \mathrm{TY}$, отн. ед. & - & 0,028 & 0,005 & 0,014 & 0,011 & $-0,041$ & 0,003 \\
\hline Сектор (по R) & - & 1 & 4 & 1 & 1 & 6 & 1 \\
\hline$\Delta \mathrm{R}^{\prime}$, отн. ед. & & $-0,034$ & $-0,014$ & $-0,019$ & $-0,112$ & $-0,004$ & $-0,018$ \\
\hline TY, отн. ед. & & 1,028 & 1,033 & 1,048 & 1,059 & 1,016 & 1,019 \\
\hline$\triangle \mathrm{TY}^{\prime}$, отн. ед. & & 0,028 & 0,033 & 0,048 & 0,059 & 0,016 & 0,019 \\
\hline Сектор по $R^{\prime}$ & & 1 & 1 & 1 & 1 & 1 & 1 \\
\hline \multicolumn{8}{|c|}{ Амурская область, Reea $=3,91$, Reea $^{\prime}=4,67$} \\
\hline R, тыс. тонн & 118,630 & 134,050 & 126,940 & 125,360 & 132,260 & 127,460 & 135,210 \\
\hline$\Delta \mathrm{R}$, & - & 0,138 & $-0,044$ & $-0,008$ & 0,063 & $-0,035$ & 0,066 \\
\hline TY,o & 1,066 & 1,090 & 0,980 & 0,899 & 1,035 & 1,040 & 0,991 \\
\hline$\Delta \mathrm{TY}, \mathrm{o}$ & - & 0,090 & $-0,020$ & $-0,101$ & 0,035 & 0,040 & $-0,009$ \\
\hline Сектор & - & 4 & 3 & 5 & 4 & 1 & 6 \\
\hline$\Delta \mathrm{R}^{\prime}$, отн. ед. & & 0,138 & 0,088 & 0,080 & 0,148 & 0,108 & 0,181 \\
\hline ТY, отн. ед. & & 1,090 & 1,068 & 0,960 & 0,994 & 1,034 & 1,024 \\
\hline$\triangle \mathrm{TY}^{\prime}$, отн. ед. & & 0,090 & 0,068 & $-0,040$ & $-0,006$ & 0,034 & 0,024 \\
\hline Сектор & & 4 & 4 & 6 & 6 & 4 & 4 \\
\hline \multicolumn{8}{|c|}{ Магаданская область, Reea $=3,10$, Reea $^{\prime}=3,33$} \\
\hline R, тыс. тонн & 25,400 & 25,130 & 29,140 & 29,040 & 29,580 & 27,270 & 30,580 \\
\hline$\Delta \mathrm{R}$, отн. ед. & - & 0,008 & 0,167 & 0,016 & 0,032 & $-0,066$ & 0,129 \\
\hline ТY, отн. ед. & 1,059 & 1,039 & 1,050 & 1,054 & 1,045 & 1,035 & 0,994 \\
\hline$\triangle \mathrm{TY}$, отн. ед. & - & 0,039 & 0,050 & 0,054 & 0,045 & 0,035 & $-0,006$ \\
\hline Сектор (по R) & - & 2 & 4 & 2 & 2 & 1 & 6 \\
\hline$\Delta \mathrm{R}^{\prime}$, отн. ед. & & 0,008 & 0,177 & 0,196 & 0,234 & 0,153 & 0,302 \\
\hline TY, отн. ед. & & 1,039 & 1,091 & 1,150 & 1,202 & 1,244 & 1,236 \\
\hline$\triangle \mathrm{TY}^{\prime}$, отн. ед. & & 0,039 & 0,091 & 0,150 & 0,202 & 0,244 & 0,236 \\
\hline Сектор по $R$ & & 2 & 4 & 4 & 4 & 2 & 4 \\
\hline \multicolumn{8}{|c|}{ Сахалинская область, Reea $=2,76$, Reea $^{\prime}=1,00$} \\
\hline R, тыс. & 100,450 & 92,450 & 86,500 & 76,830 & 64,950 & 72,500 & 76,970 \\
\hline$\Delta \mathrm{R}$, отн. ед. & - & $-0,072$ & $-0,061$ & $-0,110$ & $-0,149$ & 0,123 & 0,064 \\
\hline
\end{tabular}


Окончание таблиць А8

\begin{tabular}{|c|c|c|c|c|c|c|c|}
\hline Показатели & 2010 & 2011 & 2012 & 2013 & 2014 & 2015 & 2016 \\
\hline ТY, отн. ед & 1,089 & 1,049 & 0,978 & 1,018 & 1,012 & 1,035 & 1,001 \\
\hline$\triangle \mathrm{TY}$, отн. ед. & - & 0,049 & $-0,022$ & 0,018 & 0,012 & 0,035 & 0,001 \\
\hline Сектор (по R) & - & 1 & 3 & 1 & 1 & 4 & 4 \\
\hline$\Delta \mathrm{R}^{\prime}$, отн. ед. & & $-0,072$ & $-0,128$ & $-0,224$ & $-0,340$ & $-0,259$ & $-0,212$ \\
\hline TY, отн. ед. & & 1,049 & 1,026 & 1,044 & 1,057 & 1,094 & 1,095 \\
\hline$\triangle \mathrm{TY}^{\prime}$, отн. ед. & & 0,049 & 0,026 & 0,044 & 0,057 & 0,094 & 0,095 \\
\hline Сектор по $R^{\prime}$ & & 1 & 1 & 1 & 1 & 1 & 7 \\
\hline \multicolumn{8}{|c|}{ Еврейская автономная область, Reea $=4,43$, Reea $^{\prime}=3,83$} \\
\hline R, тыс. тонн & 22,510 & 24,920 & 24,930 & 24,200 & 18,270 & 18,640 & 19,060 \\
\hline$\triangle \mathrm{R}$, отн. ед. & - & 0,120 & 0,006 & $-0,018$ & $-0,236$ & 0,032 & 0,041 \\
\hline$\overline{\mathrm{TY}, \mathrm{C}}$ & 1,176 & 1,058 & 1,025 & 0,835 & 1,019 & 0,996 & 0,995 \\
\hline$\triangle \mathrm{TY}$, отн. ед. & - & 0,058 & 0,025 & $-0,165$ & 0,019 & $-0,004$ & $-0,005$ \\
\hline Сектор (по R) & - & 4 & 2 & 5 & 1 & 6 & 6 \\
\hline$\Delta R^{\prime}$, отн. ед. & & 0,120 & 0,126 & 0,106 & $-0,155$ & $-0,128$ & $-0,092$ \\
\hline TY, отн. ед. & & 1,058 & 1,084 & 0,906 & 0,923 & 0,919 & 0,914 \\
\hline$\triangle \mathrm{TY}^{\prime}$, отн. ед. & & 0,058 & 0,084 & $-0,094$ & $-0,077$ & $-0,081$ & $-0,086$ \\
\hline Сектор & & 4 & 4 & 6 & 3 & 3 & 3 \\
\hline \multicolumn{8}{|c|}{ Чукотский автономный округ, Reea $=3,57$, Reea $^{\prime}=2,83$} \\
\hline R, тыс. тонн & 21,620 & 22,180 & 20,990 & 20,600 & 17,850 & 21,360 & 21,120 \\
\hline$\Delta \mathrm{R}, \mathrm{c}$ & - & 0,026 & $-0,054$ & $-0,019$ & $-0,133$ & 0,197 & 0,009 \\
\hline ТҮ, отн. ед & 0,841 & 0,960 & 0,993 & 1,008 & 1,151 & 1,012 & 0,965 \\
\hline$\triangle \mathrm{TY}$, отн. ед. & - & $-0,040$ & $-0,007$ & 0,008 & 0,151 & 0,012 & $-0,035$ \\
\hline Сектор (по R) & - & 6 & 3 & 1 & 1 & 4 & 6 \\
\hline$\Delta \mathrm{R}^{\prime}$, отн. ед. & & 0,026 & $-0,029$ & $-0,047$ & $-0,174$ & $-0,012$ & $-0,004$ \\
\hline TY, отн. ед. & & 0,960 & 0,953 & 0,961 & 1,106 & 1,119 & 1,080 \\
\hline$\triangle \mathrm{TY}^{\prime}$, отн. ед. & & $-0,040$ & $-0,047$ & $-0,039$ & 0,106 & 0,119 & 0,080 \\
\hline Сектор по $R$ & & 6 & 5 & 3 & 1 & 1 & 1 \\
\hline
\end{tabular}

Примечание: ТY - индекс физического объема ВРП , на душу населения, отн. ед.; $\Delta \mathrm{TY}$ - темп прироста физического объема ВРП на душу населения отн. ед.; $\Delta \mathrm{TY}^{\prime}$ - темп прироста физического объема ВРП на душу населения отн. ед., базисные индексы; $\mathrm{R}$ - выбросы загрязняющих веществ от стационарных источников, тыс. тонн; $\Delta \mathrm{R}$ - темп прироста $\mathrm{R}$ на душу населения, отн. ед.; $\Delta \mathrm{R}^{\prime}$ - темп прироста R на душу населения, отн. ед., базисные индексы; сектор (по R) сектор, характеризующий эффект декаплинга по модели декаплинг-анализа; Reea, Reea' - рейтинг эколого-экономической привлекательности региона. Источник: расчеты авторов по данным : единая межведомственная информационно-статистическая база (ЕМИС) // https://fedstat.ru/, сайты ТОГС // http://www.gks.ru/wps/ $\mathrm{wcm} /$ connect/rosstat_main/rosstat/ru/about/territorial/site/. 
Приложение Б

Таблица Б1

\section{Структура регионов по секторам декаплинг-анализа за период 2011-2016 гг.}

\begin{tabular}{|c|c|c|c|}
\hline $\begin{array}{l}\text { Сек- } \\
\text { торы }\end{array}$ & Регионы & $\begin{array}{c}\text { Количество } \\
\text { регионов }\end{array}$ & $\begin{array}{l}\text { Процент } \\
\text { регионов }\end{array}$ \\
\hline \multicolumn{4}{|c|}{2016} \\
\hline 1 & $\begin{array}{l}\text { Белгородская область, Калужская область, } \\
\text { Липецкая область, Тульская область, Яро- } \\
\text { славская область, г. Москва, Архангель- } \\
\text { ская область, Вологодская область, Ле- } \\
\text { нинградская область, Мурманская область, } \\
\text { Новгородская область, Удмуртская рес- } \\
\text { публика, Чувашская республика, Саратов- } \\
\text { ская область, Ульяновская область, Кур- } \\
\text { ганская область, Свердловская область, } \\
\text { Республика Алтай, Республика Тыва, } \\
\text { Красноярский край, Республика Саха } \\
\text { (Якутия), Хабаровский край }\end{array}$ & 22 & 27,50 \\
\hline 2 & $\begin{array}{l}\text { Иркутская область, Чеченская Республика, } \\
\text { Ростовская область, }\end{array}$ & 3 & 3,75 \\
\hline 3 & $\begin{array}{l}\text { Ивановская область, Республика Коми, } \\
\text { Республика Калмыкия, Республика Север- } \\
\text { ная Осетия-Алания, Самарская область, } \\
\text { Челябинская область, Республика Буря- } \\
\text { тии, Приморский Край } \\
\end{array}$ & 8 & 10,00 \\
\hline 4 & $\begin{array}{l}\text { Брянская область, Владимирская область, } \\
\text { Воронежская область, Курская область, } \\
\text { Московская область, Тверская область, } \\
\text { Республика Карелия, Калининградская об- } \\
\text { ласть, Псковская область, Санкт- } \\
\text { Петербург, Республика Адыгея, Астрахан- } \\
\text { ская область, Республика Дагестан, Ка- } \\
\text { бардино-Балкарская Республика, Карачае- } \\
\text { во-Черкесская Республика, Ставрополь- } \\
\text { ский край, Республика Башкортостан, Рес- } \\
\text { публика Мордовия, Республика Татарстан, } \\
\text { Кировская область, Нижегородская об- } \\
\text { ласть, Республика Хакасия, Забайкальский } \\
\text { край, Новосибирская область, Томская об- } \\
\text { ласть, Камчатский край, Сахалинская об- } \\
\text { ласть }\end{array}$ & 27 & 33,75 \\
\hline 5 & Омская область, Смоленская область & 2 & 2,50 \\
\hline
\end{tabular}


Продолжение таблицы Б1

\begin{tabular}{|c|c|c|c|}
\hline $\begin{array}{l}\text { Сек- } \\
\text { торы }\end{array}$ & Регионы & $\begin{array}{l}\text { Количество } \\
\text { регионов }\end{array}$ & $\begin{array}{l}\text { Процент } \\
\text { регионов }\end{array}$ \\
\hline 6 & $\begin{array}{l}\text { Костромская область, Орловская область, } \\
\text { Рязанская область, Тамбовская область, } \\
\text { Волгоградская область, Краснодарский } \\
\text { край, Республика Ингушетия, Республика } \\
\text { Марий Эл, Пермский край, Оренбургская } \\
\text { область, Пензенская область, Тюменская } \\
\text { область, Алтайский край, Кемеровская об- } \\
\text { ласть, Амурская область, Магаданская об- } \\
\text { ласть, Еврейская автономная область, Чу- } \\
\text { котский автономный округ }\end{array}$ & 18 & 22,50 \\
\hline \multicolumn{4}{|c|}{2015} \\
\hline 1 & $\begin{array}{l}\text { Белгородская область, Курская область, Ли- } \\
\text { пецкая область, Московская область, Орлов- } \\
\text { ская область, Тверская область, Тульская об- } \\
\text { ласть, Архангельская область, Вологодская } \\
\text { область, Ленинградская область, Чеченская } \\
\text { Республика, Республика Марий Эл, Респуб- } \\
\text { лика Мордовия, Республика Саха (Якутия), } \\
\text { Амурская область, Магаданская область }\end{array}$ & 16 & 20,00 \\
\hline 2 & $\begin{array}{l}\text { Мурманская область, Иркутская область, } \\
\text { Ивановская область }\end{array}$ & $\overline{3}$ & 3,75 \\
\hline 3 & $\begin{array}{l}\text { Владимирская область, Костромская об- } \\
\text { ласть, Рязанская область, г. Москва, Рес- } \\
\text { публика Коми, } \\
\text { Псковская область, Республика Калмыкия, } \\
\text { Ростовская область, Республика Дагестан, } \\
\text { Карачаево-Черкесская Республика, Рес- } \\
\text { публика Башкортостан, Республика Татар- } \\
\text { стан, Удмуртская республика, Чувашская } \\
\text { республика, } \\
\text { Пермский край, Кировская область, Сара- } \\
\text { товская область, Ульяновская область, } \\
\text { Свердловская область, Тюменская об- } \\
\text { ласть, Челябинская область, Забайкаль- } \\
\text { ский край, Новосибирская область }\end{array}$ & 23 & 27,5 \\
\hline 4 & $\begin{array}{l}\text { Брянская область, Воронежская область, } \\
\text { Тамбовская область, Ярославская область, } \\
\text { Республика Карелия, Новгородская об- } \\
\text { ласть, Санкт-Петербург, Республика Ады- } \\
\text { гея, Кабардино-Балкарская Республика, } \\
\text { Ставропольский край, Пензенская область, } \\
\text { Алтайский край, Томская область, Кам- } \\
\text { чатский край, Сахалинская область, Чу- } \\
\text { котский автономный округ }\end{array}$ & 17 & 21,25 \\
\hline
\end{tabular}


Продолжение таблицы Б1

\begin{tabular}{|c|c|c|c|}
\hline $\begin{array}{l}\text { Сек- } \\
\text { торы }\end{array}$ & Регионы & \begin{tabular}{|c}
$\begin{array}{c}\text { Количество } \\
\text { регионов }\end{array}$ \\
\end{tabular} & $\begin{array}{l}\text { Процент } \\
\text { регионов }\end{array}$ \\
\hline 5 & $\begin{array}{l}\text { Самарская область, Омская область, Рес- } \\
\text { публика Ингушетия }\end{array}$ & 3 & 3,75 \\
\hline 6 & $\begin{array}{l}\text { Калужская область, Смоленская область, } \\
\text { Калининградская область, Астраханская } \\
\text { область, Волгоградская область, Красно- } \\
\text { дарский край, Республика Северная Осе- } \\
\text { тия-Алания, Нижегородская область, } \\
\text { Оренбургская область, Курганская об- } \\
\text { ласть, Республика Алтай, Республика Бу- } \\
\text { рятии, Республика Тыва, Республика Ха- } \\
\text { касия, Красноярский край, Кемеровская } \\
\text { область, Приморский Край, Хабаровский } \\
\text { край, Еврейская автономная область }\end{array}$ & 19 & 23,75 \\
\hline \multicolumn{4}{|c|}{2014} \\
\hline 1 & $\begin{array}{l}\text { Брянская область, Владимирская область, } \\
\text { Воронежская область, Костромская область, } \\
\text { Курская область, Липецкая область, Орлов- } \\
\text { ская область, Смоленская область, Тамбов- } \\
\text { ская область, Республика Карелия, Вологод- } \\
\text { ская область, Калининградская область, } \\
\text { Новгородская область, Астраханская об- } \\
\text { ласть, Волгоградская область, Республика } \\
\text { Калмыкия, Республика Дагестан, Республи- } \\
\text { ка Ингушетия, Республика Северная Осе- } \\
\text { тия-Алания, Республика Марий Эл, Респуб- } \\
\text { лика Мордовия, Республика Татарстан, } \\
\text { Пермский край, Ульяновская область, Челя- } \\
\text { бинская область, Республика Алтай, Рес- } \\
\text { публика Тыва, Республика Хакасия, Крас- } \\
\text { ноярский край, Иркутская область, Кеме- } \\
\text { ровская область, Омская область, Камчат- } \\
\text { ский край, Хабаровский край, Сахалинская } \\
\text { область, Еврейская автономная область, Чу- } \\
\text { котский автономный округ }\end{array}$ & 37 & 46,25 \\
\hline 2 & $\begin{array}{l}\text { Нижегородская область, Тульская область, } \\
\text { Магаданская область }\end{array}$ & 3 & 3,75 \\
\hline 3 & $\begin{array}{l}\text { Московская область, Республика Коми, } \\
\text { Санкт-Петербург, Краснодарский край, Ка- } \\
\text { рачаево-Черкесская Республика, Оренбург- } \\
\text { ская область, Курганская область, Сверд- } \\
\text { ловская область, Тюменская область, Рес- } \\
\text { публика Бурятии, Томская область }\end{array}$ & 11 & 13,75 \\
\hline
\end{tabular}


Продолжение таблицы Б1

\begin{tabular}{|c|c|c|c|}
\hline $\begin{array}{c}\text { Сек- } \\
\text { торы }\end{array}$ & Регионы & $\begin{array}{c}\text { Количество } \\
\text { регионов }\end{array}$ & $\begin{array}{l}\text { Процент } \\
\text { регионов }\end{array}$ \\
\hline 4 & $\begin{array}{l}\text { Белгородская область, Калужская область, } \\
\text { Ярославская область, Архангельская об- } \\
\text { ласть, Мурманская область, Псковская об- } \\
\text { ласть, Республика Адыгея, Ростовская об- } \\
\text { ласть, Кабардино-Балкарская Республика, } \\
\text { Чеченская Республика, Ставропольский } \\
\text { край, Республика Башкортостан, Удмурт- } \\
\text { ская республика, Чувашская республика, } \\
\text { Кировская область, Пензенская область, } \\
\text { Самарская область, Саратовская область, } \\
\text { Алтайский край, Новосибирская область, } \\
\text { Республика Саха (Якутия), Приморский } \\
\text { Край, Амурская область }\end{array}$ & 23 & 28,75 \\
\hline 5 & Забайкальский край & 1 & 1,25 \\
\hline 6 & $\begin{array}{l}\text { Ленинградская область, Ивановская об- } \\
\text { ласть Рязанская область, Тверская область, } \\
\text { г. Москва }\end{array}$ & 5 & 6,25 \\
\hline \multicolumn{4}{|c|}{2013} \\
\hline 1 & $\begin{array}{l}\text { Белгородская область, Брянская область, } \\
\text { Воронежская область, Костромская об- } \\
\text { ласть, Курская область, Рязанская область, } \\
\text { Тверская область, Тульская область, Ар- } \\
\text { хангельская область, Калининградская об- } \\
\text { ласть, Псковская область, Астраханская } \\
\text { область, Краснодарский край, Ростовская } \\
\text { область, Республика Дагестан, Республика } \\
\text { Марий Эл, Республика Мордовия, Уд- } \\
\text { муртская республика, Нижегородская об- } \\
\text { ласть, Оренбургская область, Самарская } \\
\text { область, Саратовская область, Свердлов- } \\
\text { ская область, Тюменская область, Челя- } \\
\text { бинская область, Республика Тыва, Рес- } \\
\text { публика Хакасия, } \\
\text { Алтайский край, Красноярский край, Ир- } \\
\text { кутская область, Новосибирская область, } \\
\text { Омская область, Томская область, Хаба- } \\
\text { ровский край, Сахалинская область, Чу- } \\
\text { котский автономный округ }\end{array}$ & 36 & 45,00 \\
\hline 2 & $\begin{array}{l}\text { Новгородская область, Владимирская об- } \\
\text { ласть, Ивановская область, Липецкая об- } \\
\text { ласть, Тамбовская область, Волгоградская } \\
\text { область, Магаданская область }\end{array}$ & 7 & 8,75 \\
\hline
\end{tabular}


Продолжение таблищы Б1

\begin{tabular}{|c|c|c|c|}
\hline $\begin{array}{l}\text { Сек- } \\
\text { торы }\end{array}$ & Регионы & $\begin{array}{c}\text { Количество } \\
\text { регионов }\end{array}$ & $\begin{array}{l}\text { Процент } \\
\text { регионов }\end{array}$ \\
\hline 3 & $\begin{array}{l}\text { Кабардино-Балкарская Республика, Кара- } \\
\text { чаево-Черкесская Республика, г. Москва, } \\
\text { Чувашская республика, Камчатский край, } \\
\text { Приморский Край }\end{array}$ & 6 & 7,50 \\
\hline 4 & $\begin{array}{l}\text { Московская область, Орловская область, } \\
\text { Смоленская область, Ярославская область, } \\
\text { Республика Карелия, Мурманская область, } \\
\text { Республика Адыгея, Республика Калмыкия, } \\
\text { Республика Ингушетия, Республика Север- } \\
\text { ная Осетия-Алания, Ставропольский край, } \\
\text { Республика Башкортостан, Республика Та- } \\
\text { тарстан, Пермский край, Кировская область, } \\
\text { Пензенская область, Ульяновская область, } \\
\text { Курганская область, Республика Бурятии, } \\
\text { Республика Саха (Якутия) }\end{array}$ & 20 & 25,00 \\
\hline 5 & $\begin{array}{l}\text { Амурская область, Еврейская автономная } \\
\text { область }\end{array}$ & 2 & 2,50 \\
\hline 6 & $\begin{array}{l}\text { Республика Коми, Вологодская область, } \\
\text { Ленинградская область, Санкт-Петербург, } \\
\text { Республика Алтай, Забайкальский край, } \\
\text { Кемеровская область, Чеченская Респуб- } \\
\text { лика, Калужская область }\end{array}$ & 9 & 11,25 \\
\hline \multicolumn{4}{|c|}{2012} \\
\hline 1 & $\begin{array}{l}\text { Белгородская область, Владимирская об- } \\
\text { ласть, Курская область, Липецкая область, } \\
\text { Московская область, Орловская область, } \\
\text { Смоленская область, Тверская область, } \\
\text { Ярославская область, } \\
\text { Республика Коми, Архангельская область, } \\
\text { Мурманская область, Псковская область, } \\
\text { Санкт-Петербург, Волгоградская область, } \\
\text { Карачаево-Черкесская Республика, Чечен- } \\
\text { ская Республика, } \\
\text { Республика Башкортостан, Пермский } \\
\text { край, Пензенская область, Самарская об- } \\
\text { ласть, Ульяновская область, Челябинская } \\
\text { область, Забайкальский край, Новосибир- } \\
\text { ская область, Томская область }\end{array}$ & 26 & 32,50 \\
\hline 2 & $\begin{array}{l}\text { Брянская область, Воронежская область, } \\
\text { Калужская область, Костромская область, } \\
\text { Рязанская область, Тамбовская область, } \\
\text { Тульская область, Вологодская область }\end{array}$ & 19 & 23,75 \\
\hline
\end{tabular}


Продолжение таблицы Б1

\begin{tabular}{|c|c|c|c|}
\hline $\begin{array}{l}\text { Сек- } \\
\text { торы }\end{array}$ & Регионы & $\begin{array}{c}\text { Количество } \\
\text { регионов }\end{array}$ & $\begin{array}{l}\text { Процент } \\
\text { регионов }\end{array}$ \\
\hline & $\begin{array}{l}\text { Калининградская область, Ленинградская } \\
\text { область, Новгородская область, Астрахан- } \\
\text { ская область, Республика Татарстан, Ни- } \\
\text { жегородская область, Свердловская об- } \\
\text { ласть, Республика Хакасия, Красноярский } \\
\text { край, Республика Саха (Якутия), Еврей- } \\
\text { ская автономная область }\end{array}$ & & \\
\hline 3 & $\begin{array}{l}\text { Курганская область, Ивановская область, } \\
\text { Сахалинская область, Чукотский автоном- } \\
\text { ный округ, Амурская область }\end{array}$ & 5 & 6,00 \\
\hline 4 & $\begin{array}{l}\text { г. Москва, Республика Карелия, Республи- } \\
\text { ка Адыгея, Республика Калмыкия, Крас- } \\
\text { нодарский край, Ростовская область, Рес- } \\
\text { публика Дагестан, } \\
\text { Республика Ингушетия, Кабардино- } \\
\text { Балкарская Республика, Республика Север- } \\
\text { ная Осетия-Алания, Ставропольский край, } \\
\text { Республика Марий Эл, Республика Мордо- } \\
\text { вия, Удмуртская республика, Чувашская } \\
\text { республика, Кировская область, Оренбург- } \\
\text { ская область, Саратовская область, Респуб- } \\
\text { лика Бурятии, Республика Тыва, } \\
\text { Алтайский край, Иркутская область, Ом- } \\
\text { ская область, Камчатский край, Хабаров- } \\
\text { ский край, Магаданская область }\end{array}$ & 26 & 32,50 \\
\hline 5 & Кемеровская область, Приморский Край & 2 & 2,50 \\
\hline 6 & Тюменская область, Республика Алтай & 2 & 2.50 \\
\hline \multicolumn{4}{|c|}{2011} \\
\hline 1 & $\begin{array}{l}\text { Воронежская область, Костромская область, } \\
\text { Липецкая область, Московская область, Ря- } \\
\text { занская область, Ярославская область, } \\
\text { г. Москва, Республика Карелия, Архангель- } \\
\text { ская область, Вологодская область, Кали- } \\
\text { нинградская область, Ленинградская об- } \\
\text { ласть, Мурманская область, Новгородская } \\
\text { область, Волгоградская область, Ростовская } \\
\text { область, Республика Дагестан, Республика } \\
\text { Ингушетия, Кабардино-Балкарская Респуб- } \\
\text { лика, Республика Северная Осетия-Алания, }\end{array}$ & 39 & 48,75 \\
\hline
\end{tabular}


Окончание таблицьь Б1

\begin{tabular}{|c|c|c|c|}
\hline $\begin{array}{c}\text { Сек- } \\
\text { торы }\end{array}$ & Регионы & $\begin{array}{c}\text { Количество } \\
\text { регионов }\end{array}$ & $\begin{array}{l}\text { Процент } \\
\text { регионов }\end{array}$ \\
\hline & $\begin{array}{l}\text { Чеченская Республика, Республика Марий } \\
\text { Эл, Чувашская республика, Кировская об- } \\
\text { ласть, Нижегородская область, Самарская } \\
\text { область, Курганская область, Свердловская } \\
\text { область, Челябинская область, Республика } \\
\text { Бурятии, Республика Тыва, Республика Ха- } \\
\text { касия, Алтайский край, Забайкальский край, } \\
\text { Кемеровская область, Республика Саха } \\
\text { (Якутия), Камчатский край, Хабаровский } \\
\text { край, Сахалинская область }\end{array}$ & & \\
\hline 2 & $\begin{array}{l}\text { Белгородская область, Брянская область, } \\
\text { Владимирская область, Ивановская об- } \\
\text { ласть, Калужская область, Курская об- } \\
\text { ласть, Орловская область, Смоленская об- } \\
\text { ласть, Тамбовская область, Астраханская } \\
\text { область, Республика Калмыкия, Ставро- } \\
\text { польский край, Республика Башкортостан, } \\
\text { Республика Мордовия, Удмуртская рес- } \\
\text { публика, Красноярский край, Иркутская } \\
\text { область, Новосибирская область, Омская } \\
\text { область, Приморский Край, Магаданская } \\
\text { область }\end{array}$ & 21 & 26,25 \\
\hline 3 & - & 0 & 0,00 \\
\hline 4 & $\begin{array}{l}\text { Тверская область, Тульская область, Рес- } \\
\text { публика Коми, Псковская область, Санкт- } \\
\text { Петербург, Республика Адыгея, Красно- } \\
\text { дарский край, Карачаево-Черкесская Рес- } \\
\text { публика, Республика Татарстан, Пермский } \\
\text { край, Оренбургская область, Пензенская } \\
\text { область, Саратовская область, Ульянов- } \\
\text { ская область, Тюменская область, Респуб- } \\
\text { лика Алтай, Томская область, Амурская } \\
\text { область, Еврейская автономная область }\end{array}$ & 19 & 23,75 \\
\hline 5 & - & 0 & 0,00 \\
\hline 6 & Чукотский автономный округ & 1 & 1,25 \\
\hline
\end{tabular}

Примечание. Источник: расчеты авторов. 
Таблиия 2Б

\section{Структура регионов по секторам декаплинг-анализа за период 2011-2016 гг. (базовый - 2010 г.)}

\begin{tabular}{|c|c|c|c|}
\hline $\begin{array}{c}\text { Секто- } \\
\text { ры }\end{array}$ & Регионы & $\begin{array}{c}\text { Количество } \\
\text { регионов }\end{array}$ & $\begin{array}{l}\text { Процент } \\
\text { регионов }\end{array}$ \\
\hline \multicolumn{4}{|c|}{2016} \\
\hline 1 & $\begin{array}{l}\text { Белгородская область, Владимирская об- } \\
\text { ласть, Воронежская область, Костромская } \\
\text { область, Курская область, Липецкая об- } \\
\text { ласть, Орловская область, Рязанская об- } \\
\text { ласть, Тульская область, Архангельская об- } \\
\text { ласть, Вологодская область, Калининград- } \\
\text { ская область, Мурманская область, Волго- } \\
\text { градская область, Республика Калмыкия, } \\
\text { Ростовская область, Республика Дагестан, } \\
\text { Карачаево-Черкесская Республика, Респуб- } \\
\text { лика Северная Осетия-Алания, Чеченская } \\
\text { Республика, Чувашская республика, Перм- } \\
\text { ский край, Нижегородская область, Орен- } \\
\text { бургская область, Самарская область, Уль- } \\
\text { яновская область, Курганская область, } \\
\text { Свердловская область, Челябинская об- } \\
\text { ласть, Республика Тыва, Республика Хака- } \\
\text { сия, Забайкальский край, Красноярский } \\
\text { край, Новосибирская область, Омская об- } \\
\text { ласть, Томская область, Камчатский край, } \\
\text { Хабаровский край, Сахалинская область, } \\
\text { Чукотский автономный округ }\end{array}$ & 40 & 50,00 \\
\hline 2 & $\begin{array}{l}\text { Брянская область, Тамбовская область, } \\
\text { Тверская область, Ярославская область, } \\
\text { Республика Коми, Ленинградская об- } \\
\text { ласть, Новгородская область, Астрахан- } \\
\text { ская область, Республика Марий Эл, Рес- } \\
\text { публика Мордовия, Кировская область, } \\
\text { Саратовская область, Алтайский край, } \\
\text { Иркутская область }\end{array}$ & 14 & 17,50 \\
\hline 3 & $\begin{array}{l}\text { Ивановская область, г. Москва, Тюмен- } \\
\text { ская область, Приморский Край, Еврей- } \\
\text { ская автономная область }\end{array}$ & 5 & 6,25 \\
\hline 4 & $\begin{array}{l}\text { Калужская область, Московская область, } \\
\text { Смоленская область, Республика Карелия, } \\
\text { Псковская область, Санкт-Петербург, } \\
\text { Республика Адыгея, Краснодарский край }\end{array}$ & 19 & 23,75 \\
\hline
\end{tabular}


Продолжние таблищы 2Б

\begin{tabular}{|c|c|c|c|}
\hline $\begin{array}{c}\text { Секто- } \\
\text { ры }\end{array}$ & Регионы & $\begin{array}{c}\text { Количество } \\
\text { регионов }\end{array}$ & $\begin{array}{l}\text { Процент } \\
\text { регионов }\end{array}$ \\
\hline & $\begin{array}{l}\text { Республика Ингушетия, Кабардино- } \\
\text { Балкарская Республика, Ставропольский } \\
\text { край, Республика Башкортостан, Респуб- } \\
\text { лика Татарстан, Удмуртская республика, } \\
\text { Пензенская область, Республика Алтай, } \\
\text { Республика Саха (Якутия), Амурская об- } \\
\text { ласть, Магаданская область }\end{array}$ & & \\
\hline 5 & Республика Бурятии, Кемеровская область & 2 & 2,50 \\
\hline 6 & - & 0 & 0,00 \\
\hline \multicolumn{4}{|c|}{2015} \\
\hline 1 & 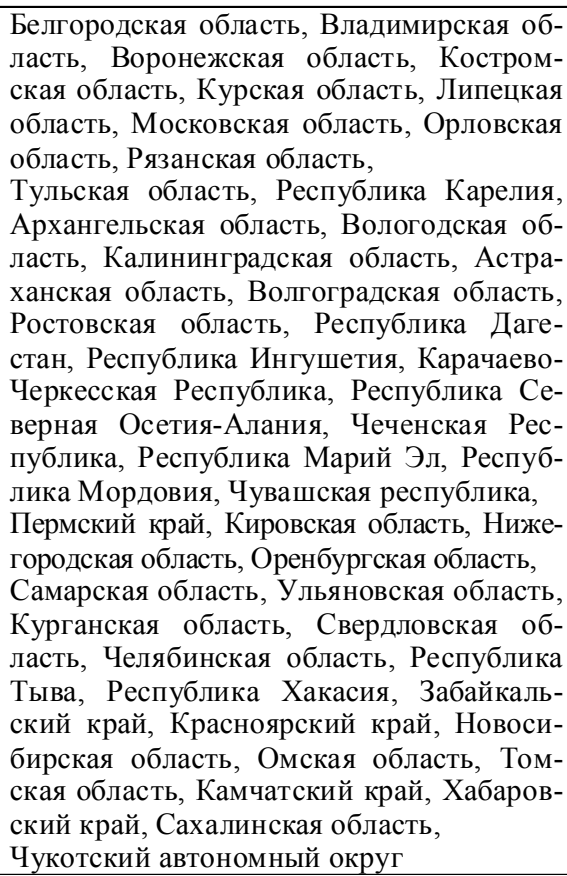 & 45 & 56,25 \\
\hline 2 & $\begin{array}{l}\text { Брянская область, Тамбовская область, } \\
\text { Тверская область, Ярославская область, } \\
\text { Ленинградская область, Мурманская об- } \\
\text { ласть, Республика Калмыкия, Кабардино- } \\
\text { Балкарская Республика, Республика } \\
\text { Башкортостан, Республика Татарстан, } \\
\text { Алтайский край, Иркутская область, } \\
\text { Магаданская область }\end{array}$ & 13 & 16,25 \\
\hline
\end{tabular}


Продолжние таблищы 2Б

\begin{tabular}{|c|c|c|c|}
\hline $\begin{array}{c}\text { Секто- } \\
\text { ры }\end{array}$ & Регионы & $\begin{array}{c}\text { Количество } \\
\text { регионов }\end{array}$ & $\begin{array}{l}\text { Процент } \\
\text { регионов }\end{array}$ \\
\hline 3 & $\begin{array}{l}\text { Ивановская область, г. Москва, Тюмен- } \\
\text { ская область, Приморский Край, Еврей- } \\
\text { ская автономная область }\end{array}$ & 5 & 6,25 \\
\hline 4 & $\begin{array}{l}\text { Калужская область, Смоленская область, } \\
\text { Республика Коми, Новгородская область, } \\
\text { Псковская область, Санкт-Петербург, } \\
\text { Республика Адыгея, Краснодарский } \\
\text { край, Ставропольский край, Удмуртская } \\
\text { республика, Пензенская область, Сара- } \\
\text { товская область, Республика Алтай, Рес- } \\
\text { публика Бурятии, Республика Саха (Яку- } \\
\text { тия), Амурская область }\end{array}$ & 16 & 20,00 \\
\hline 5 & Кемеровская область & 1 & 1,25 \\
\hline 6 & - & 0 & 0,00 \\
\hline \multicolumn{4}{|c|}{2014} \\
\hline 1 & $\begin{array}{l}\text { Белгородская область, Владимирская об- } \\
\text { ласть, Воронежская область, Костром- } \\
\text { ская область, Курская область, Липецкая } \\
\text { область, Московская область, Орловская } \\
\text { область, Рязанская область, Тамбовская } \\
\text { область, Республика Карелия, Архан- } \\
\text { гельская область, Калининградская об- } \\
\text { ласть, Мурманская область, Новгород- } \\
\text { ская область, Астраханская область, Вол- } \\
\text { гоградская область, Республика Даге- } \\
\text { стан, Республика Ингушетия, Кабардино- } \\
\text { Балкарская Республика, } \\
\text { Карачаево-Черкесская Республика, Рес- } \\
\text { публика Северная Осетия-Алания, Рес- } \\
\text { публика Марий Эл, Пермский край, Ни- } \\
\text { жегородская область, Оренбургская об- } \\
\text { ласть, Самарская область, Ульяновская } \\
\text { область, Курганская область, Свердлов- } \\
\text { ская область, Челябинская область, Рес- } \\
\text { публика Тыва, Республика Хакасия, Ал- } \\
\text { тайский край, Забайкальский край, Крас- } \\
\text { ноярский край, Новосибирская область, } \\
\text { Омская область, Томская область, Кам- } \\
\text { чатский край, Хабаровский край, Саха- } \\
\text { линская область, Чукотский автономный } \\
\text { округ }\end{array}$ & 43 & 53,75 \\
\hline
\end{tabular}


Продолжние таблищы 2Б

\begin{tabular}{|c|c|c|c|}
\hline $\begin{array}{c}\text { Секто- } \\
\text { ры }\end{array}$ & Регионы & $\begin{array}{c}\text { Количество } \\
\text { регионов }\end{array}$ & $\begin{array}{l}\text { Процент } \\
\text { регионов }\end{array}$ \\
\hline 2 & $\begin{array}{l}\text { Брянская область, Смоленская область, } \\
\text { Тульская область, Ярославская область, } \\
\text { г. Москва, Вологодская область, Ростов- } \\
\text { ская область, Республика Мордовия, Рес- } \\
\text { публика Татарстан, Иркутская область }\end{array}$ & 10 & 12,50 \\
\hline 3 & $\begin{array}{l}\text { Ивановская область, Тюменская область, } \\
\text { Кемеровская область, Приморский Край, } \\
\text { Еврейская автономная область }\end{array}$ & 5 & 6,25 \\
\hline 4 & $\begin{array}{l}\text { Калужская область, Тверская область, } \\
\text { Республика Коми, Ленинградская об- } \\
\text { ласть, Псковская область, Санкт- } \\
\text { Петербург, Республика Адыгея, Респуб- } \\
\text { лика Калмыкия, Краснодарский край, } \\
\text { Чеченская Республика, Ставропольский } \\
\text { край, Республика Башкортостан, Уд- } \\
\text { муртская республика, Чувашская респуб- } \\
\text { лика, Кировская область, Пензенская об- } \\
\text { ласть, Саратовская область, Республика } \\
\text { Алтай, Республика Бурятии, Республика } \\
\text { Саха (Якутия), Магаданская область }\end{array}$ & 21 & 26,25 \\
\hline 5 & - & 0 & 0,00 \\
\hline 6 & Амурская область & 1 & 1,25 \\
\hline \multicolumn{4}{|c|}{2013} \\
\hline 1 & $\begin{array}{l}\text { Белгородская область, Владимирская об- } \\
\text { ласть, Воронежская область, Ивановская } \\
\text { область, Костромская область, Курская } \\
\text { область, Липецкая область, Московская } \\
\text { область, Рязанская область, г. Москва, } \\
\text { Архангельская область, Калининградская } \\
\text { область, Мурманская область, Волго- } \\
\text { градская область, Республика Дагестан, } \\
\text { Кабардино-Балкарская Республика, Рес- } \\
\text { публика Северная Осетия-Алания, Че- } \\
\text { ченская Республика, Республика Марий } \\
\text { Эл, Чувашская республика, Нижегород- } \\
\text { ская область, } \\
\text { Оренбургская область, Самарская об- } \\
\text { ласть, Ульяновская область, Свердлов- } \\
\text { ская область, Тюменская область, Челя- } \\
\text { бинская область, Республика Тыва, Рес- } \\
\text { публика Хакасия, Алтайский край, За- } \\
\text { байкальский край, Красноярский край, }\end{array}$ & 38 & 47,5 \\
\hline
\end{tabular}


Продолжние таблищы 2Б

\begin{tabular}{|c|c|c|c|}
\hline $\begin{array}{c}\text { Секто- } \\
\text { ры }\end{array}$ & Регионы & $\begin{array}{c}\text { Количество } \\
\text { регионов }\end{array}$ & $\begin{array}{l}\text { Процент } \\
\text { регионов }\end{array}$ \\
\hline & $\begin{array}{l}\text { Новосибирская область, Омская область, } \\
\text { Томская область, Камчатский край, Ха- } \\
\text { баровский край, Сахалинская область }\end{array}$ & & \\
\hline 2 & $\begin{array}{l}\text { Брянская область, Орловская область, Там- } \\
\text { бовская область, Тверская область, Туль- } \\
\text { ская область, Ярославская область, Воло- } \\
\text { годская область, Ленинградская область, } \\
\text { Новгородская область, Астраханская об- } \\
\text { ласть, Ростовская область, Республика Ин- } \\
\text { гушетия, Карачаево-Черкесская Республи- } \\
\text { ка, Республика Мордовия, Республика Та- } \\
\text { тарстан, Кировская область, Саратовская } \\
\text { область, Курганская область, Иркутская } \\
\text { область, Республика Саха (Якугия) }\end{array}$ & 20 & 25 \\
\hline 3 & $\begin{array}{l}\text { Приморский Край, Чукотский автоном- } \\
\text { ный округ }\end{array}$ & 2 & 2,5 \\
\hline 4 & $\begin{array}{l}\text { Калужская область, Смоленская область, } \\
\text { Республика Карелия, Республика Коми, } \\
\text { Псковская область, Санкт-Петербург, } \\
\text { Республика Адыгея, Республика Калмы- } \\
\text { кия, Краснодарский край, Ставрополь- } \\
\text { ский край, Республика Башкортостан, } \\
\text { Удмуртская республика, Пермский край, } \\
\text { Пензенская область, Республика Буря- } \\
\text { тии, Магаданская область }\end{array}$ & 16 & 20 \\
\hline 5 & Кемеровская область & 1 & 1,25 \\
\hline 6 & $\begin{array}{l}\text { Республика Алтай, Амурская область, } \\
\text { Еврейская автономная область }\end{array}$ & 3 & 3,75 \\
\hline \multicolumn{4}{|c|}{2012} \\
\hline 1 & $\begin{array}{l}\text { Владимирская область, Костромская об- } \\
\text { ласть, Липецкая область, Московская об- } \\
\text { ласть, Орловская область, Рязанская об- } \\
\text { ласть, Смоленская область, Ярославская } \\
\text { область, Архангельская область, Кали- } \\
\text { нинградская область, Ленинградская об- } \\
\text { ласть, Мурманская область, Волгоград- } \\
\text { ская область, Республика Дагестан, Рес- } \\
\text { публика Ингушетия, Кабардино- } \\
\text { Балкарская Республика, Республика Се- } \\
\text { верная Осетия-Алания, Чеченская Рес- } \\
\text { публика, Нижегородская область, Пен- } \\
\text { зенская область, Самарская область, }\end{array}$ & 34 & 42,50 \\
\hline
\end{tabular}


Продолжние таблищы 2Б

\begin{tabular}{|c|c|c|c|}
\hline $\begin{array}{c}\text { Секто- } \\
\text { ры }\end{array}$ & Регионы & $\begin{array}{c}\text { Количество } \\
\text { регионов }\end{array}$ & $\begin{array}{l}\text { Процент } \\
\text { регионов }\end{array}$ \\
\hline & $\begin{array}{l}\text { Ульяновская область, Курганская об- } \\
\text { ласть, Свердловская область, Челябин- } \\
\text { ская область, Республика Тыва, Респуб- } \\
\text { лика Хакасия, Забайкальский край, Ново- } \\
\text { сибирская область, Томская область, } \\
\text { Камчатский край, Приморский Край, Ха- } \\
\text { баровский край, Сахалинская область }\end{array}$ & & \\
\hline 2 & $\begin{array}{l}\text { Белгородская область, Брянская область, } \\
\text { Воронежская область, Калужская об- } \\
\text { ласть, Курская область, Тамбовская об- } \\
\text { ласть, Тверская область, Карелия, Воло- } \\
\text { годская область, Новгородская область, } \\
\text { Астраханская область, Ростовская об- } \\
\text { ласть, Карачаево-Черкесская Республика, } \\
\text { Ставропольский край, Республика Баш- } \\
\text { кортостан, Республика Марий Эл, Рес- } \\
\text { публика Татарстан, Чувашская респуб- } \\
\text { лика, Пермский край, Кировская область, } \\
\text { Алтайский край, Красноярский край, Ом- } \\
\text { ская область, Республика Саха (Якутия) }\end{array}$ & 24 & 30,00 \\
\hline 3 & $\begin{array}{l}\text { Ивановская область, Кемеровская об- } \\
\text { ласть }\end{array}$ & 2 & 2,5 \\
\hline 4 & $\begin{array}{l}\text { Тульская область, г. Москва, Республика } \\
\text { Коми, Псковская область, Санкт- } \\
\text { Петербург, Республика Адыгея, Респуб- } \\
\text { лика Калмыкия, Краснодарский край, } \\
\text { Республика Мордовия, Удмуртская рес- } \\
\text { публика, Оренбургская область, } \\
\text { Саратовская область, Тюменская об- } \\
\text { ласть, Республика Бурятии, Иркутская } \\
\text { область, Амурская область, Магаданская } \\
\text { область, Еврейская автономная область }\end{array}$ & 18 & 22,50 \\
\hline 5 & Чукотский автономный округ & 1 & 1,25 \\
\hline 6 & Республика Алтай, & 1 & 1,25 \\
\hline \multicolumn{4}{|c|}{2011} \\
\hline 1 & $\begin{array}{l}\text { Воронежская область, Костромская об- } \\
\text { ласть, Липецкая область, Московская об- } \\
\text { ласть, Рязанская область, Ярославская } \\
\text { область, г. Москва, Республика Карелия, } \\
\text { Архангельская область, Вологодская об- } \\
\text { ласть, Калининградская область, Ленин- } \\
\text { градская область, Мурманская область }\end{array}$ & 39 & 48,75 \\
\hline
\end{tabular}


Окончание таблищы 2Б

\begin{tabular}{|c|c|c|c|}
\hline $\begin{array}{c}\text { Секто- } \\
\text { ры }\end{array}$ & Регионы & $\begin{array}{c}\text { Количество } \\
\text { регионов }\end{array}$ & $\begin{array}{l}\text { Процент } \\
\text { регионов }\end{array}$ \\
\hline & $\begin{array}{l}\text { Новгородская область, Волгоградская } \\
\text { область, Ростовская область, Республика } \\
\text { Дагестан, Республика Ингушетия, Ка- } \\
\text { бардино-Балкарская Республика, Респуб- } \\
\text { лика Северная Осетия-Алания, Чеченская } \\
\text { Республика, Республика Марий Эл, Чу- } \\
\text { вашская республика, Кировская область, } \\
\text { Нижегородская область, Самарская об- } \\
\text { ласть, Курганская область, Свердловская } \\
\text { область, Челябинская область, Республи- } \\
\text { ка Бурятии, Республика Тыва, Республи- } \\
\text { ка Хакасия, Алтайский край, Забайкаль- } \\
\text { ский край, Кемеровская область, Респуб- } \\
\text { лика Саха (Якутия), Камчатский край, } \\
\text { Хабаровский край, Сахалинская область }\end{array}$ & & \\
\hline 2 & $\begin{array}{l}\text { Белгородская область, Брянская область, } \\
\text { Владимирская область, Ивановская об- } \\
\text { ласть, Калужская область, Курская об- } \\
\text { ласть, Орловская область, Смоленская } \\
\text { область, Тамбовская область, Астрахан- } \\
\text { ская область, Республика Калмыкия, } \\
\text { Ставропольский край, Республика Баш- } \\
\text { кортостан, Республика Мордовия, Уд- } \\
\text { муртская республика, Красноярский } \\
\text { край, Иркутская область, Новосибирская } \\
\text { область, Омская область, Приморский } \\
\text { Край, Магаданская область }\end{array}$ & 21 & 26,25 \\
\hline 3 & - & 0 & 0,00 \\
\hline 4 & $\begin{array}{l}\text { Тверская область, Тульская область, Рес- } \\
\text { публика Коми, Псковская область, } \\
\text { Санкт-Петербург, Республика Адыгея, } \\
\text { Краснодарский край, Карачаево- } \\
\text { Черкесская Республика, Республика Та- } \\
\text { тарстан, Пермский край, Оренбургская } \\
\text { область, Пензенская область, Саратов- } \\
\text { ская область, Ульяновская область, Тю- } \\
\text { менская область, Республика Алтай, } \\
\text { Томская область, Амурская область, Ев- } \\
\text { рейская автономная область }\end{array}$ & 19 & 23,75 \\
\hline 5 & - & 0 & 0,00 \\
\hline 6 & Чукотский автономный округ & 1 & 1,25 \\
\hline
\end{tabular}

Примечание. Источник: расчеты авторов. 
Приложение В

\section{Рейтинг «эколого-экономического риска» российских регионов}

\begin{tabular}{|c|c|c|c|c|}
\hline $\begin{array}{c}\text { № } \\
\text { ПI/II }\end{array}$ & $\begin{array}{c}\text { Рейтинг } \\
\text { «эколого- } \\
\text { экономиче- } \\
\text { ского риска» } \\
\text { регионов } \\
\end{array}$ & Регионы & $\begin{array}{c}\text { Рейтинго- } \\
\text { вая шкала } \\
\text { «зеленых» } \\
\text { ценных бу- } \\
\text { маг } \\
\end{array}$ & $\begin{array}{c}\text { Характеристика } \\
\text { рейтинговой } \\
\text { шкалы }\end{array}$ \\
\hline 1. & 1,14 & Липецкая область & $\mathrm{A}+$ & $\begin{array}{l}\text { Низкий уровень } \\
\text { риска }\end{array}$ \\
\hline 2. & 1,43 & Тульская область & $\mathrm{A}+$ & $\begin{array}{l}\text { Низкий уровень } \\
\text { риска }\end{array}$ \\
\hline 3. & 1,57 & Архангельская область & $\mathrm{A}+$ & $\begin{array}{l}\text { Низкий уровень } \\
\text { риска }\end{array}$ \\
\hline 4. & 1,62 & Белгородская область & $\mathrm{A}+$ & $\begin{array}{l}\text { Низкий уровень } \\
\text { риска }\end{array}$ \\
\hline 5. & 1,81 & Вологодская область & $\mathrm{A}+$ & $\begin{array}{l}\text { Низкий уровень } \\
\text { риска }\end{array}$ \\
\hline 6. & 1,86 & Иркутская область & $\mathrm{A}+$ & $\begin{array}{l}\text { Низкий уровень } \\
\text { риска }\end{array}$ \\
\hline 7. & 1,91 & Курская область & $\mathrm{A}+$ & $\begin{array}{l}\text { Низкий уровень } \\
\text { риска }\end{array}$ \\
\hline 8. & 1,95 & Новгородская область & $\mathrm{A}+$ & $\begin{array}{l}\text { Низкий уровень } \\
\text { риска }\end{array}$ \\
\hline 9. & 1,95 & Свердловская область & $\mathrm{A}+$ & $\begin{array}{l}\text { Низкий уровень } \\
\text { риска }\end{array}$ \\
\hline 10. & 2,05 & Ульяновская область & A & $\begin{array}{l}\text { Удовлетвори- } \\
\text { тельный уровень } \\
\text { риска }\end{array}$ \\
\hline 11. & 2,05 & Челябинская область & A & $\begin{array}{l}\text { Удовлетвори- } \\
\text { тельный уровень } \\
\text { риска }\end{array}$ \\
\hline 12. & 2,10 & $\begin{array}{l}\text { Республика Саха (Яку- } \\
\text { тия) }\end{array}$ & A & $\begin{array}{l}\text { Удовлетвори- } \\
\text { тельный уровень } \\
\text { риска }\end{array}$ \\
\hline 13. & 2,19 & Республика Мордовия & A & $\begin{array}{l}\text { Удовлетвори- } \\
\text { тельный уровень } \\
\text { риска }\end{array}$ \\
\hline 14. & 2,23 & Мурманская область & A & $\begin{array}{l}\text { Удовлетвори- } \\
\text { тельный уровень } \\
\text { риска }\end{array}$ \\
\hline 15. & 2,33 & Красноярский край & A & $\begin{array}{l}\text { Удовлетвори- } \\
\text { тельный уровень } \\
\text { риска }\end{array}$ \\
\hline
\end{tabular}


Продолжение таблицьы

\begin{tabular}{|c|c|c|c|c|}
\hline $\begin{array}{c}\text { № } \\
\text { II/II }\end{array}$ & $\begin{array}{c}\text { Рейтинг } \\
\text { «эколого- } \\
\text { Экономиче- } \\
\text { ского риска» } \\
\text { регионов }\end{array}$ & Регионы & $\begin{array}{c}\text { Рейтинго- } \\
\text { вая шкала } \\
\text { «еленых»" } \\
\text { ценных бу- } \\
\text { маг }\end{array}$ & $\begin{array}{c}\text { Характеристика } \\
\text { рейтинговой } \\
\text { шкалы }\end{array}$ \\
\hline 16. & 2,38 & Удмуртская Республика & $\mathrm{A}$ & $\begin{array}{l}\text { Удовлетвори- } \\
\text { тельный уровень } \\
\text { риска }\end{array}$ \\
\hline 17. & 2,48 & Саратовская область & A & $\begin{array}{l}\text { Удовлетвори- } \\
\text { тельный уровень } \\
\text { риска }\end{array}$ \\
\hline 18. & 2,48 & Республика Тыва & A & $\begin{array}{l}\text { Удовлетвори- } \\
\text { тельный уровень } \\
\text { риска }\end{array}$ \\
\hline 19. & 2,48 & Хабаровский край & A & $\begin{array}{l}\text { Удовлетвори- } \\
\text { тельный уровень } \\
\text { риска }\end{array}$ \\
\hline 20. & 2,52 & Владимирская область & $\mathrm{A}$ & $\begin{array}{l}\text { Удовлетвори- } \\
\text { тельный уровень } \\
\text { риска }\end{array}$ \\
\hline 21. & 2,57 & Чеченская Республика* & A & $\begin{array}{l}\text { Удовлетвори- } \\
\text { тельный уровень } \\
\text { риска }\end{array}$ \\
\hline 22. & 2,62 & Ростовская область & $\mathrm{A}$ & $\begin{array}{l}\text { Удовлетвори- } \\
\text { тельный уровень } \\
\text { риска }\end{array}$ \\
\hline 23. & 2,62 & $\begin{array}{l}\text { Чувашская Республи- } \\
\text { ка - Чувашия }\end{array}$ & $\mathrm{A}$ & $\begin{array}{l}\text { Удовлетвори- } \\
\text { тельный уровень } \\
\text { риска }\end{array}$ \\
\hline 24. & 2,67 & Воронежская область & $\mathrm{A}$ & $\begin{array}{l}\text { Удовлетвори- } \\
\text { тельный уровень } \\
\text { риска }\end{array}$ \\
\hline 25. & 2,67 & Московская область & $\mathrm{A}$ & $\begin{array}{l}\text { Удовлетвори- } \\
\text { тельный уровень } \\
\text { риска }\end{array}$ \\
\hline 26. & 2,71 & Брянская область & A & $\begin{array}{l}\text { Удовлетвори- } \\
\text { тельный уровень } \\
\text { риска }\end{array}$ \\
\hline 27. & 2,71 & Ярославская область & A & $\begin{array}{l}\text { Удовлетвори- } \\
\text { тельный уровень } \\
\text { риска }\end{array}$ \\
\hline 28. & 2,71 & Республика Марий Эл & $\mathrm{A}$ & $\begin{array}{l}\text { Удовлетвори- } \\
\text { тельный уровень } \\
\text { риска }\end{array}$ \\
\hline 29. & 2,76 & Ленинградская область & A & $\begin{array}{l}\text { Удовлетвори- } \\
\text { тельный уровень } \\
\text { риска }\end{array}$ \\
\hline
\end{tabular}


Продолжение таблиць

\begin{tabular}{|c|c|c|c|c|}
\hline $\begin{array}{c}\text { № } \\
\text { II/II }\end{array}$ & $\begin{array}{c}\text { Рейтинг } \\
\text { «эколого- } \\
\text { экономиче- } \\
\text { ского риска» } \\
\text { регионов }\end{array}$ & Регионы & $\begin{array}{c}\text { Рейтинго- } \\
\text { вая шкала } \\
\text { «зеленых» } \\
\text { ценных бу- } \\
\text { маг }\end{array}$ & $\begin{array}{c}\text { Характеристика } \\
\text { рейтинговой } \\
\text { шкалы }\end{array}$ \\
\hline 30. & 2,76 & Сахалинская область & $\mathrm{A}$ & $\begin{array}{l}\text { Приемлемый } \\
\text { уровень риска. }\end{array}$ \\
\hline 31. & 2,81 & Республика Калмыкия & A & $\begin{array}{l}\text { Удовлетвори- } \\
\text { тельный уровень } \\
\text { риска }\end{array}$ \\
\hline 32. & 2,91 & Орловская область & A & $\begin{array}{l}\text { Удовлетвори- } \\
\text { тельный уровень } \\
\text { риска }\end{array}$ \\
\hline 33. & 2,95 & Тверская область & A & $\begin{array}{l}\text { Удовлетвори- } \\
\text { тельный уровень } \\
\text { риска }\end{array}$ \\
\hline 34. & 2,95 & Новосибирская область & A & $\begin{array}{l}\text { Удовлетвори- } \\
\text { тельный уровень } \\
\text { риска }\end{array}$ \\
\hline 35. & 3,00 & Костромская область & $\mathrm{B}+$ & $\begin{array}{l}\text { Приемлемый } \\
\text { уровень риска }\end{array}$ \\
\hline 36. & 3,00 & $\begin{array}{l}\text { Город Москва столица } \\
\text { Российской Федерации } \\
\text { город федерального } \\
\text { значения }\end{array}$ & $\mathrm{B}+$ & $\begin{array}{l}\text { Приемлемый } \\
\text { уровень риска }\end{array}$ \\
\hline 37. & 3,00 & $\begin{array}{ll}\text { Республика } & \text { Татарстан } \\
\text { (Татарстан) } & \\
\end{array}$ & $\overline{\mathrm{B}+}$ & $\begin{array}{l}\text { Приемлемый } \\
\text { уровень риска }\end{array}$ \\
\hline 38. & 3,05 & Псковская область & $\mathrm{B}+$ & $\begin{array}{l}\text { Приемлемый } \\
\text { уровень риска }\end{array}$ \\
\hline 39. & 3,10 & Самарская область & $\mathrm{B}+$ & $\begin{array}{l}\text { Приемлемый } \\
\text { уровень риска }\end{array}$ \\
\hline 40. & 3,10 & Томская область & $\mathrm{B}+$ & $\begin{array}{l}\text { Приемлемый } \\
\text { уровень риска }\end{array}$ \\
\hline 41. & 3,10 & Магаданская область & $\mathrm{B}+$ & $\begin{array}{l}\text { Приемлемый } \\
\text { уровень риска }\end{array}$ \\
\hline 42. & 3,14 & Ивановская область & $\mathrm{B}+$ & $\begin{array}{l}\text { Приемлемый } \\
\text { уровень риска }\end{array}$ \\
\hline 43. & 3,14 & $\begin{array}{l}\text { Калининградская об- } \\
\text { ласть }\end{array}$ & $\mathrm{B}+$ & $\begin{array}{l}\text { Приемлемый } \\
\text { уровень риска }\end{array}$ \\
\hline 44. & 3,14 & Республика Хакасия & $\mathrm{B}+$ & $\begin{array}{l}\text { Приемлемый } \\
\text { уровень риска }\end{array}$ \\
\hline 45. & 3,14 & $\begin{array}{l}\text { Карачаево-Черкесская } \\
\text { Республика }\end{array}$ & $\mathrm{B}+$ & $\begin{array}{l}\text { Приемлемый } \\
\text { уровень риска }\end{array}$ \\
\hline 46. & 3,14 & Камчатский край & $\mathrm{B}+$ & $\begin{array}{l}\text { Приемлемый } \\
\text { уровень риска }\end{array}$ \\
\hline 47. & 3,19 & Астраханская область & $\mathrm{B}+$ & $\begin{array}{l}\text { Приемлемый } \\
\text { уровень риска }\end{array}$ \\
\hline
\end{tabular}


Продолжение таблицьы

\begin{tabular}{|c|c|c|c|c|}
\hline $\begin{array}{l}\text { № } \\
\text { II/II }\end{array}$ & $\begin{array}{c}\text { Рейтинг } \\
\text { «эколого- } \\
\text { экономиче- } \\
\text { ского риска» } \\
\text { регионов }\end{array}$ & Регионы & $\begin{array}{c}\text { Рейтинго- } \\
\text { вая шкала } \\
\text { «зеленых» } \\
\text { ценных бу- } \\
\text { маг }\end{array}$ & $\begin{array}{c}\text { Характеристика } \\
\text { рейтинговой } \\
\text { шкалы }\end{array}$ \\
\hline 48. & 3,19 & Курганская область & $\mathrm{B}+$ & $\begin{array}{l}\text { Приемлемый } \\
\text { уровень риска }\end{array}$ \\
\hline 49. & 3,29 & Республика Карелия & $\mathrm{B}+$ & $\begin{array}{l}\text { Приемлемый } \\
\text { уровень риска }\end{array}$ \\
\hline 50. & 3,29 & Республика Коми & $\mathrm{B}+$ & $\begin{array}{l}\text { Приемлемый } \\
\text { уровень риска }\end{array}$ \\
\hline 51. & 3,33 & $\begin{array}{l}\text { Нижегородская об- } \\
\text { ласть }\end{array}$ & $\mathrm{B}+$ & $\begin{array}{l}\text { Приемлемый } \\
\text { уровень риска }\end{array}$ \\
\hline 52. & 3,38 & $\begin{array}{l}\text { Республика Башкорто- } \\
\text { стан }\end{array}$ & $\mathrm{B}+$ & $\begin{array}{l}\text { Приемлемый } \\
\text { уровень риска }\end{array}$ \\
\hline 53. & 3,43 & Тамбовская область & $\mathrm{B}+$ & $\begin{array}{l}\text { Приемлемый } \\
\text { уровень риска }\end{array}$ \\
\hline 54. & 3,43 & Омская область & $\mathrm{B}+$ & $\begin{array}{l}\text { Приемлемый } \\
\text { уровень риска }\end{array}$ \\
\hline 55. & 3,48 & Пермский край & $\mathrm{B}+$ & $\begin{array}{l}\text { Приемлемый } \\
\text { уровень риска }\end{array}$ \\
\hline 56. & 3,48 & $\begin{array}{l}\text { Республика Северная } \\
\text { Осетия-Алания }\end{array}$ & $\mathrm{B}+$ & $\begin{array}{l}\text { Приемлемый } \\
\text { уровень риска }\end{array}$ \\
\hline 57. & 3,52 & Республика Алтай & $\mathrm{B}+$ & $\begin{array}{l}\text { Приемлемый } \\
\text { уровень риска }\end{array}$ \\
\hline 58. & 3,57 & $\begin{array}{l}\text { Чукотский автономный } \\
\text { округ }\end{array}$ & $\mathrm{B}+$ & $\begin{array}{l}\text { Приемлемый } \\
\text { уровень риска }\end{array}$ \\
\hline 59. & 3,62 & Калужская область & $\mathrm{B}+$ & $\begin{array}{l}\text { Приемлемый } \\
\text { уровень риска }\end{array}$ \\
\hline 60. & 3,62 & Кировская область & $\mathrm{B}+$ & $\begin{array}{l}\text { Приемлемый } \\
\text { уровень риска }\end{array}$ \\
\hline 61. & 3,71 & $\begin{array}{l}\text { Кабардино-Балкарская } \\
\text { Республика }\end{array}$ & $\mathrm{B}+$ & $\begin{array}{l}\text { Приемлемый } \\
\text { уровень риска }\end{array}$ \\
\hline 62. & 3,76 & Волгоградская область & $\mathrm{B}+$ & $\begin{array}{l}\text { Приемлемый } \\
\text { уровень риска }\end{array}$ \\
\hline 63. & 3,81 & Смоленская область & $\mathrm{B}+$ & $\begin{array}{l}\text { Приемлемый } \\
\text { уровень риска }\end{array}$ \\
\hline 64. & 3,81 & $\begin{array}{lr}\text { Город Санкт-Петербург } \\
\text { город } \\
\text { значения }\end{array}$ & $\mathrm{B}+$ & $\begin{array}{l}\text { Приемлемый } \\
\text { уровень риска }\end{array}$ \\
\hline 65. & 3,81 & Забайкальский край & $\mathrm{B}+$ & $\begin{array}{l}\text { Приемлемый } \\
\text { уровень риска }\end{array}$ \\
\hline 66. & 3,86 & Республика Бурятия & $\mathrm{B}+$ & $\begin{array}{l}\text { Приемлемый } \\
\text { уровень риска }\end{array}$ \\
\hline
\end{tabular}


Окончание таблицы

\begin{tabular}{|c|c|c|c|c|}
\hline $\begin{array}{l}\text { № } \\
\text { п/II }\end{array}$ & $\begin{array}{c}\text { Рейтинг } \\
\text { «эколого- } \\
\text { экономиче- } \\
\text { ского риска» } \\
\text { регионов }\end{array}$ & Регионы & $\begin{array}{c}\text { Рейтинго- } \\
\text { вая шкала } \\
\text { «зеленых» } \\
\text { ценных бу- } \\
\text { маг }\end{array}$ & $\begin{array}{c}\text { Характеристика } \\
\text { рейтинговой } \\
\text { шкалы }\end{array}$ \\
\hline 67. & 3,91 & Республика Дагестан & $\mathrm{B}+$ & $\begin{array}{l}\text { Приемлемый } \\
\text { уровень риска }\end{array}$ \\
\hline 68. & 3,91 & Ставропольский край & $\mathrm{B}+$ & $\begin{array}{l}\text { Приемлемый } \\
\text { уровень риска }\end{array}$ \\
\hline 69. & 3,91 & Тюменская область & $\mathrm{B}+$ & $\begin{array}{l}\text { Приемлемый } \\
\text { уровень риска }\end{array}$ \\
\hline 70. & 3,91 & Амурская область & $\mathrm{B}+$ & $\begin{array}{l}\text { Приемлемый } \\
\text { уровень риска }\end{array}$ \\
\hline 71. & 3,95 & Рязанская область & $\mathrm{B}+$ & $\begin{array}{l}\text { Приемлемый } \\
\text { уровень риска }\end{array}$ \\
\hline 72. & 4,00 & Республика Адыгея & B & $\begin{array}{l}\text { Высокий уровень } \\
\text { риска }\end{array}$ \\
\hline 73. & 4,00 & Алтайский край & $\mathrm{B}$ & $\begin{array}{l}\text { Высокий уровень } \\
\text { риска }\end{array}$ \\
\hline 74. & 4,05 & Приморский Край & B & $\begin{array}{l}\text { Высокий уровень } \\
\text { риска }\end{array}$ \\
\hline 75. & 4,10 & $\begin{array}{l}\text { Республика Ингуше- } \\
\text { тия * }\end{array}$ & $\mathrm{B}$ & $\begin{array}{l}\text { Высокий уровень } \\
\text { риска }\end{array}$ \\
\hline 76. & 4,23 & Краснодарский край & B & $\begin{array}{l}\text { Высокий уровень } \\
\text { риска }\end{array}$ \\
\hline 77. & 4,29 & Пензенская область & B & $\begin{array}{l}\text { Высокий уровень } \\
\text { риска }\end{array}$ \\
\hline 78. & 4,43 & Оренбургская область & B & $\begin{array}{l}\text { Высокий уровень } \\
\text { риска }\end{array}$ \\
\hline 79. & 4,43 & $\begin{array}{l}\text { Еврейская автономная } \\
\text { область }\end{array}$ & B & $\begin{array}{l}\text { Высокий уровень } \\
\text { риска }\end{array}$ \\
\hline 80. & 4,71 & Кемеровская область & B & $\begin{array}{l}\text { Высокий уровень } \\
\text { риска }\end{array}$ \\
\hline
\end{tabular}

Примечание. Источник: расчеты авторов. 


\section{Приложение Г}

\section{Рейтинг «эколого-экономического риска» федеральных округов РФ}

\begin{tabular}{|c|c|c|c|c|c|c|c|c|c|}
\hline \multirow{2}{*}{$\begin{array}{l}\text { Рейтинго- } \\
\text { вая шкала }\end{array}$} & \multirow{2}{*}{$\begin{array}{c}\text { Характеристика } \\
\text { рейтинговой шкалы }\end{array}$} & \multicolumn{2}{|c|}{ РФ } & \multicolumn{2}{|c|}{ ЦФО } & \multicolumn{2}{|c|}{ СФ30 } & \multicolumn{2}{|c|}{ ЮФО } \\
\hline & & g & $\%$ & g & $\%$ & g & $\%$ & g & $\%$ \\
\hline $\mathrm{A}+$ & $\begin{array}{l}\text { Низкий уровень } \\
\text { риска }\end{array}$ & 9 & 11,25 & 4 & 22,22 & 3 & 30,00 & 0 & 0,00 \\
\hline $\mathrm{A}$ & $\begin{array}{l}\text { Удовлетворитель- } \\
\text { ный уровень риска }\end{array}$ & 25 & 31,25 & 7 & 38,89 & 2 & 20,00 & 2 & 33,33 \\
\hline $\mathrm{B}+$ & $\begin{array}{l}\text { Приемлемый уро- } \\
\text { вень риска }\end{array}$ & 37 & 46,25 & 7 & 39,89 & 5 & 50,00 & 2 & 33,33 \\
\hline B & $\begin{array}{l}\text { Высокий уровень } \\
\text { риска }\end{array}$ & 9 & 11,25 & 0 & 0,00 & 0 & 0,00 & 2 & 33,33 \\
\hline $\mathrm{C}$ & $\begin{array}{l}\text { Очень высокий уро- } \\
\text { вень риска }\end{array}$ & 0 & 0,00 & 0 & 0,00 & 0 & 0,00 & 0 & 0,00 \\
\hline Итого & & 80 & 100,00 & 18 & 100,00 & 10 & 100,00 & 6 & 100,00 \\
\hline
\end{tabular}

Окончание таблиць

\begin{tabular}{|c|l|r|c|r|r|r|r|r|r|r|r|r|}
\hline \multirow{2}{*}{$\begin{array}{c}\text { Рейтинго- } \\
\text { вая шкала }\end{array}$} & $\begin{array}{l}\text { Характеристи- } \\
\text { ка рейтинговой } \\
\text { шкалы }\end{array}$ & \multicolumn{2}{|c|}{$\mathbf{\text { СКФО }}$} & \multicolumn{2}{|c|}{ ПФО } & \multicolumn{2}{|c|}{ УФО } & \multicolumn{2}{|c|}{ СФО } & \multicolumn{2}{|c|}{ ДФО } \\
\hline А + & $\begin{array}{l}\text { Низкий уро- } \\
\text { вень риска }\end{array}$ & 0 & 0,00 & 0 & 0,00 & 1 & 25,00 & 1 & 8,33 & 0 & 0 \\
\hline А & $\begin{array}{l}\text { Удовлетвори- } \\
\text { тельный уро- } \\
\text { вень риска }\end{array}$ & 1 & 14,29 & 6 & 42,86 & 1 & 25,00 & 3 & 25,00 & 3 & 33,33 \\
\hline В+ & $\begin{array}{l}\text { Приемлемый } \\
\text { уровень риска }\end{array}$ & 5 & 71,43 & 6 & 42,86 & 2 & 50,00 & 6 & 50,00 & 4 & 44,45 \\
\hline В & $\begin{array}{l}\text { Высокий уро- } \\
\text { вень риска }\end{array}$ & 1 & 14,28 & 2 & 14,28 & 0 & 0,00 & 2 & 16,67 & 2 & 22,22 \\
\hline С & $\begin{array}{l}\text { Очень высокий } \\
\text { уровень риска }\end{array}$ & 0 & 0,00 & 0 & 0,00 & 0 & 0,00 & 0 & 0,00 & 0 & 0,00 \\
\hline Итого & & 7 & $\mathbf{1 0 0 , 0 0}$ & $\mathbf{1 4}$ & $\mathbf{1 0 0 , 0 0}$ & $\mathbf{4}$ & $\mathbf{1 0 0 , 0 0}$ & $\mathbf{1 2}$ & $\mathbf{1 0 0 , 0 0}$ & $\mathbf{9}$ & $\mathbf{1 0 0 , 0 0}$ \\
\hline
\end{tabular}

Примечания: при анализе регионов использовались данные Территориальных отделений Росстата с учетом: УФО: Тюменская область с автономными округами (Ханты-Мансийский автономный округ-Югра, Ямало-Ненецкий автономный округ); СЗФО: Архангельская область с Ненецким автономным округом; ЮФО: без Крыма и г. Севастополь ввиду отсутствия данных за весь анализируемый период; ДФО: Камчатский край, включая Корякский округ, g - количество регионов в группе.

Источник: расчеты авторов. 


\title{
ЭКОЛОГО-ЭКОНОМИЧЕСКОЕ РАЗВИТИЕ РЕГИОНОВ: \\ СОВЕРШЕНСТВОВАНИЕ МЕТОДОЛОГИИ И МЕТОДИКИ ОЦЕНКИ
}

\author{
Монография \\ Под редакцией доктора экономических наук, \\ профессора И.Д. Аникиной
}

\author{
Главный редактор А.В. Шестакова \\ Верстка и техническое редактирование Е.С. Решетниковой \\ Оформление обложки Н.Н. Захаровой \\ Печатается в авторской редакции.
}

Подписано в печать 24.102019 г. Формат 60×84/16.

Бумага офсетная. Гарнитура Таймс. Усл. печ. л. 11,4.

Уч. -изд. л. 12,3. Тираж 500 экз. (1-й завод 1-50 экз.). Заказ . «C» 94 .

Волгоградский государственный университет.

400062 Волгоград, просп. Университетский, 100. www.volsu.ru

Отпечатано в издательстве

Волгоградского государственного университета.

400062 Волгоград, ул. Богданова, 32. E-mail: izvolgu@volsu.ru 